MURILO RUIZ FERRO

\title{
PONTOS DE CONVERGÊNCIA \\ ENTRE AS TESES DOUTRINÁRIAS BRASILEIRAS \\ QUANTO AO PRINCÍPIO DA SUPREMACIA DO \\ INTERESSE PÚBLICO SOBRE O PARTICULAR
}

Dissertação de Mestrado

Orientador: Professora Doutora Maria Sylvia Zanella Di Pietro

FACULDADE DE DIREITO DA UNIVERSIDADE DE SÃO PAULO

SÃo PAULO

2014 
PONTOS DE CONVERGÊNCIA ENTRE AS TESES DOUTRINÁRIAS BRASILEIRAS QUANTO AO PRINCÍPIO DA SUPREMACIA DO INTERESSE PÚBLICO SOBRE O PARTICULAR

\author{
MURILO RUIZ FERRO
}

Dissertação apresentada à Banca Examinadora da Faculdade de Direito da Universidade de São Paulo, como exigência para obtenção do título de Mestre em Direito, sob a orientação da Professora Doutora Maria Sylvia Zanella Di Pietro.

SÃO PAULO 


\title{
FOLHA DE AVALIAÇÃO
}

\author{
MURILO RUIZ FERRO
}

PONTOS DE CONVERGÊNCIA ENTRE AS TESES DOUTRINÁRIAS BRASILEIRAS QUANTO AO PRINCÍPIO DA SUPREMACIA DO INTERESSE PÚBLICO SOBRE O PARTICULAR

Dissertação apresentada à Faculdade de Direito da Universidade de São Paulo para obtenção do título de Mestre em Direito Área de Concentração: Direito do Estado

\section{Banca Examinadora}

Professor Dr.:

Instituição: Assinatura:

Professor Dr.:

Instituição: Assinatura:

Professor Dr.:

Instituição: Assinatura: 


\section{AGRADECIMENTOS}

A DEUS, antes de tudo e por tudo.

Aos meus pais Admir Donizeti Ferro e Diomar Pontes Ruiz Ferro, para além das infinitas razões de agradecer, por serem meus pais.

A minha querida orientadora Maria Sylvia Zanella Di Pietro, pela confiança, carinho e palavras de incentivo, que foram determinantes nos momentos de dificuldade, insegurança e desânimo.

E aos amigos:

Aos professores-amigos Fernando Dias Menezes de Almeida e Floriano Peixoto de Azevedo Marques Neto, pelos debates, sugestões, críticas, provocações. E por serem referências no caminho que trilho; por serem meus ídolos, na verdade.

Aos amigos-professores Carlos Eduardo Batalha da Silva e Costa e Luciano de Camargo Penteado, pelos conhecimentos transmitidos, mais fora do que dentro de sala de aula.

Aos amigos-parentes: meu primo William Vicentini, pelas palavras de apoio, sempre benvindas; minha irmã Bianca Ruiz Ferro, pelo amor de irmã caçula que não diminui apesar das cobranças e implicâncias do irmão mais velho; e meu irmão Rogério Ruiz Ferro, pelo companheirismo cotidiano, bem como pela paciência que raramente falha.

Aos amigos e colegas que, mesmo indiretamente, compartilharam comigo alguma angústia, indecisão, inquietação, euforia ou alegria desta jornada: Eurico Souza Leite Filho, Miguel Cordovani, Lucas Rodrigues Oliveira Silva, Rodrigo Augusto Amaral, Denise Barbosa, Luiz Mário Pereira Souza Gomes, Guilherme Jardim Jurksaitis (agradecimento, por extensão, ao professor Carlos Ari Sundfeld e a todos os colaboradores da SBDP - Sociedade Brasileira de Direito Público), André Castro Carvalho, Juliana Bonacorsi de Palma, Guilherme Reinsdorfer, Ágata Bobbio Ferraz, Rafael Roque Garofano, Eduardo Tognetti, Maria Adelaide França Amaral, Paulo de Tarso, Adriana Bertoloto, Renata Rita Volcov, Lucas Norberto, Fernando Moreno Machado, Viviane Stadler, Claudia Urano Machado, Lara Porto Reno, Anelise Schuler, Vivian de Holanda Zanini, Vivian Sousa, Rafael Walbach Schwind, Paulo Pessoa Silva, Maria Denise Pessoa 
Silva, Flávia Possi Demetrov Rodrigues, Thiago Reis, Natalia Pasquini Moretti, Bruno Cunha, Mariana Zago, Glauce Lara, Rafael Traldi Moura e Haline Conrad.

E por fim, a todos os funcionários da Biblioteca Florestan Fernandes, da Biblioteca da Faculdade de Direito de São Bernardo do Campo e, principalmente, de todas as Bibliotecas da Faculdade de Direito da Universidade de São Paulo, que foram, na realidade, os meus melhores amigos durante todo este tempo de pesquisa.

A todos vocês... Obrigado! 
Certa vez, ouvi dizer que "um sonho que se sonha só é apenas um sonho, mas o sonho que se sonha junto é realidade".

Dedico este trabalho àqueles que sempre sonharam os meus sonhos : meu pai Admir Donizeti Ferro e minha mãe Diomar Pontes Ruiz Ferro 


\section{RESUMO}

Dissertação voltada à investigação do debate doutrinário acerca do princípio da supremacia do interesse público sobre o particular no direito administrativo brasileiro. Busca identificar pontos de convergência entre as teses doutrinárias brasileiras que discutem este princípio para então, a partir de tais pontos, verificar a existência de algum substrato teórico evolutivo decorrente dos consensos identificados. Examina o debate mencionado através do estabelecimento de três dimensões de análise: a primeira, investigando as divergências teóricas que dizem respeito à noção jurídica de interesse público; a segunda, investigando as divergências teóricas que problematizam o caráter principiológico da supremacia do interesse público sobre o particular; e a terceira, investigando as divergências teóricas existentes quanto à centralidade do princípio da supremacia do interesse público sobre o particular no ordenamento jurídico brasileiro em potencial situação de compatibilidade ou incompatibilidade com o princípio da dignidade da pessoa humana e, consequentemente, com os direitos fundamentais do homem e com a teleologia democrática, promanada da constituição federal de 1988. Precede a mencionada investigação, sem embargo, alguns apontamentos acerca de questões correlatas ao debate, sobretudo, a importância do papel desempenhado pela doutrina administrativista tanto no processo evolutivo do princípio da supremacia do interesse público sobre o particular quanto no desenvolvimento histórico do direito administrativo brasileiro como um todo.

Palavras-chave: direito administrativo brasileiro, doutrina administrativista, debate doutrinário, princípios jurídicos, supremacia do interesse público sobre o particular. 


\begin{abstract}
The present dissertation aims at investigating the doutrinary debate about the principle of supremacy of the public over private interest concerning Brazilian administrative law. The study focuses on identifying points of convergence within Brazilian doutrinary theses that discuss this principle to then - from those points on - verify the existence of any theoretical evolutionary substrate emerging from the consensus identified. It examines the above-mentioned debate by establishing three dimensions of analysis: the first, investigating the theoretical divergences regarding the juridical concept of public interest; the second, investigating the theoretical divergences that problematize the law principle character of the supremacy of the public over private interest; and the third, investigating the theoretical divergences within the centrality of the principle of supremacy of the public over private interest concerning the Brazilian juridical system in potential situation of compatibility or incompatibility with the principle of dignity of the human being and, consequently, with the fundamental human rights and with the democratic teleology, which arises from the federal constitution of 1988. However, a few issues regarding questions related to the debate precede the above-mentioned investigation, especially the importance of the role of administrative doctrine not only in the evolutionary process of the principle of supremacy of the public over private interest but also in the historical development of Brazilian administrative law as a whole.
\end{abstract}

Key-words: Brazilian administrative law, administrative law doctrine, doutrinary debate, law principles, supremacy of the public over private interest. 


\section{SUMÁRIO}

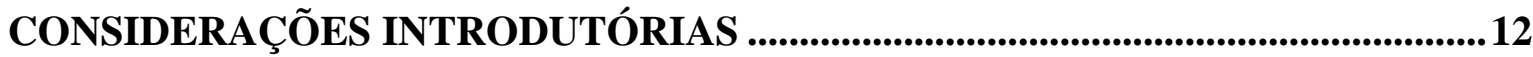

Objeto, hipótese e objetivo: considerações sobre a delimitação da proposta de pesquisa ........ 12

Materiais e método: considerações sobre a delimitação do "universo" de pesquisa.................. 14

Estrutura e formatação: considerações sobre a delimitação dos aspectos formais de pesquisa

\section{PRIMEIRA PARTE: DO OBJETO INVESTIGADO}

I. EXPLICAÇÕES NECESSÁRIAS ACERCA DO PROBLEMA DOUTRINÁRIO DO PRINCÍPIO DA SUPREMACIA DO INTERESSE PÚBLICO SOBRE O PARTICULAR NO DIREITO ADMINISTRATIVO BRASILEIRO..............................20

1.1. "Desenho" da problematização proposta. 20

1.2. Questão terminológica: dogmática administrativista ou doutrina administrativista? ..... 23

1.3. O papel da doutrina na formação e evolução do direito administrativo. 27

1.4. O problema doutrinário do princípio da supremacia do interesse público sobre o particular no direito administrativo brasileiro

II. A CONSTRUÇÃO DOUTRINÁRIA DO PRINCÍPIO DA SUPREMACIA DO INTERESSE PÚBLICO SOBRE O PARTICULAR NO DIREITO ADMINISTRATIVO BRASILEIRO ......................................................................34

2.1. O método tópico e as grandes dicotomias do direito. 34

2.2. A grande dicotomia direito público e direito privado e o valor metodológico da exorbitância nos primeiros esboços teóricos do regime jurídico-administrativo propriamente dito 36

2.3. Um destaque paralelo: a puissance publique e sua influência na teorização do princípio da supremacia do interesse público sobre o particular 40

2.4. Uma ressalva: a doutrina administrativista brasileira influenciada por referenciais teóricos anteriores à puissance publique 
2.5. Os primeiros registros doutrinários do princípio da supremacia do interesse público sobre o particular no direito administrativo brasileiro 47

2.6. O princípio da supremacia do interesse público sobre o particular metodologicamente teorizado pela doutrina administrativista brasileiro 55

\section{AS LINHAS GERAIS DO DEBATE DOUTRINÁRIO DO PRINCÍPIO DA SUPREMACIA DO INTERESSE PÚBLICO SOBRE O PARTICULAR NO DIREITO ADMINISTRATIVO BRASILEIRO.

3.1. Contextualização jurídica do debate: o sentido principiológico da constitucionalização do direito administrativo no Brasil.

3.2. Apanhado histórico do debate: uma visão panorâmica sobre o diálogo dos doutrinadores 73 78

\section{SEGUNDA PARTE: DA INVESTIGAÇÃO DO OBJETO}

IV. PRIMEIRA DIMENSÃO DE ANÁLISE DO DEBATE: AS DIVERGÊNCIAS TEÓRICAS ACERCA DA NOÇÃO JURÍDICA DE INTERESSE PÚBLICO ...........82

4.1. Um contraste de perspectivas doutrinárias 82

4.2. Duas formas de enxergar a indeterminação conceitual da noção jurídica de interesse público, segundo a doutrina administrativista brasileira 84

4.3. Linhas de pensamento importantes para a discussão em torno da noção jurídica de interesse público: a tônica da bipartição conceitual 87

4.4. Sobre a teoria de Renato ALESSI: um erro de leitura na doutrina administrativista brasileira? Uma análise necessária sobre a utilização das expressões interesse $(s)$ público(s) primário(s) e interesse(s) público(s) secundário(s) no direito administrativo brasileiro. 96

V. SEGUNDA DIMENSÃO DE ANÁLISE DO DEBATE: AS DIVERGÊNCIAS TEÓRICAS ACERCA DO CARÁTER PRINCIPIOLÓGICO DA SUPREMACIA DO INTERESSE PÚBLICO SOBRE O PARTICULAR ...........................................105

5.1. A polêmica da palavra supremacia: considerações gerais para a compreensão do problema 105 
5.2. A incompatibilidade da supremacia do interesse público sobre o particular com o conceito de princípio jurídico nos termos descritos por Humberto Bergmann ÁVILA........ 111 5.3. O problema do conceito de princípio jurídico no discurso de Humberto Bergmann ÁVILA: algumas inflexões sobre as proposições conceituais de Celso Antônio BANDEIRA de MELLO e Robert ALEXY no direito administrativo brasileiro 114

5.4. Ainda sobre a - interpretação que se faz da - teoria de Robert ALEXY: o princípio da supremacia do interesse público sobre o particular como mandamento de otimização no discurso de Fábio Medina OSÓRIO.

VI. TERCEIRA DIMENSÃO DE ANÁLISE DO DEBATE: AS DIVERGÊNCIAS TEÓRICAS ACERCA DA CENTRALIDADE DO PRINCÍPIO DA SUPREMACIA DO INTERESSE PÚBLICO SOBRE O PARTICULAR NO ORDENAMENTO JURÍDICO BRASILEIRO_...............................................................................................127

6.1. Supremacia do interesse público versus supremacia da dignidade da pessoa humana? Um dilema de hierarquia principiológica entre os administrativistas brasileiros 127

6.2. Do dilema principiológico ao efetivo problema da compatibilidade do princípio da supremacia do interesse público sobre o particular com a constituição federal de 1988 ...... 131 6.3. Interesses públicos e privados na sociedade pluriclasse contemporânea: notas sobre a indispensável busca do equilíbrio na discussão, no direito administrativo brasileiro, acerca da relação existente entre a atuação estatal e a preservação dos direitos fundamentais do homem 136

6.4. Análise do diálogo travado pelos doutrinadores administrativistas brasileiros especificamente quanto ao princípio da supremacia do interesse público sobre o particular à luz da teoria dos direitos fundamentais do homem 141

CONCLUSÕES 146

Diagnóstico preliminar: a polissemia e a sinonímia como impasses linguísticos do debate .. 146

Verificação da hipótese de pesquisa . 148

Síntese dos pontos convergentes identificados no debate 148

Palavras finais 150 


\section{CONSIDERAÇÕES INTRODUTÓRIAS}

\section{Objeto, hipótese e objetivo: considerações sobre a delimitação da proposta de pesquisa}

Esta dissertação presta-se ao estudo do atual debate doutrinário acerca do princípio da supremacia do interesse público sobre o particular no direito administrativo brasileiro. O intento é, em boa medida, inspirado por algumas das ideias de Niklas LUHMANN, em especial, pelo conjunto de proposições que consubstanciam o seu modo de descrever os mecanismos de comunicação dentro do que é, por ele, chamado de sistema científico.

É que, embora pouca relação possa haver entre Niklas LUHMANN e qualquer tema de direito administrativo, o que aqui serve de inspiração é a proposição do autor no sentido de que o direito - bem como a economia, a política e etc - é um sistema de comunicação. E como parte desta comunicação é desenvolvida no plano teórico, logo, a comunicação científica também integra o complexo de instâncias comunicacionais do sistema jurídico. Sendo assim, deve-se dizer que a presente dissertação busca investigar, portanto, os problemas de comunicação que dizem respeito à teoria do princípio da supremacia do interesse público sobre o particular no direito administrativo brasileiro.

Mas quais problemas de comunição poderiam existir no debate ora mencionado? Cuida-se de indagação que certamente revela a necessidade de delimitação da hipótese de pesquisa a ser perseguida por todo o caminho trilhado nas páginas seguintes.

Pois bem, neste sentido, é preciso consignar que chamou a atenção, ainda à época das primeiras leituras, isto é, dos primeiros contatos com a matéria - o debate propriamente dito -, certa passagem no artigo escrito por Maria Sylvia Zanella DI PIETRO, aduzindo que "a doutrina que se considera inovadora (...) incide no erro de achar que está inovando, quando, na realidade, está fazendo afirmações que desde longa data são amplamente aceitas pela doutrina e pela jurisprudência”. Com isso, pode-se dizer que a primeira das inquietações a mover a presente dissertação de mestrado surgiu, portanto, de mero e até simplório exercício lógico, eis que, de certo modo, tal apontamento por parte da autora torna cogitável, logicamente, a seguinte hipótese: se "a doutrina que se considera 
inovadora (...) está fazendo afirmações que desde longa data são amplamente aceitas pela doutrina e pela jurisprudência", isso significa que existem pontos de convergência no debate travado entre os críticos e os defensores do princípio da supremacia do interesse público sobre o particular. Eis, assim, a formulação de uma hipótese para ser confirmada.

Por conseguinte, registre-se também que novas inquietações foram, pouco a pouco, ganhando forma e importância, pois, começava a ficar cada vez mais claro que a potencial confirmação desta hipótese suscitada imporia, com efeito, a investigação de algumas outras indagações, que dela, naturalmente, estariam a decorrer. Por exemplo: quais seriam estes pontos de convergência doutrinária? Sobre o que, afinal, no direito administrativo brasileiro, concordam os críticos e os defensores do princípio da supremacia do interesse público sobre o particular?

O raciocínio apto a justificar os esforços acadêmicos empenhados na busca de respostas para as questões acima apresentadas é bastante simples, direto e pragmático: se identificar os pontos de convergência imaginados for uma medida acadêmica útil para o monitoramento da tendência evolutiva do princípio da supremacia do interesse público sobre o particular, então, tem-se aqui - ao final da pesquisa, caso bem sucedida, é verdade - uma contribuição científica válida para o estudo do direito administrativo brasileiro como um todo.

Ocorre que a busca deste objetivo - investigar e identificar os pontos de convergência no debate travado entre os críticos e os defensores do princípio da supremacia do interesse público sobre o particular -, entretanto, requer uma proposta metodológica diferente das assumidas nos trabalhos de mesma pertinência temática publicados por outros autores até o presente momento. Explica-se: a diferença ora referida consiste em não assumir - tal como os doutrinadores têm assumido -, a priori, uma posição contrária ou favorável ao princípio da supremacia do interesse público sobre o particular; ${ }^{1}$ mas tão somente investigar, guiando-se pelo objetivo acima definido, os embates argumentativos que dividem os juristas neste já tão repercutido debate doutrinário, para que deste estudo, então, possa-se confirmar a hipótese aventada, bem como responder

\footnotetext{
${ }^{1}$ Segue, à guisa de ilustração, o exemplo da posição assumida por Daniel Wunder HACHEM: "Cabe registrar, desde logo, que a posição ora adotada inclina-se para a improcedência de tais críticas, como se pode extrair de plano do título da segunda parte deste estudo". Daniel Wunder HACHEM. Princípio constitucional da supremacia do interesse público. p. 216.
} 
aos questionamentos que naturalmente passam a ser relevantes, partindo desta potencial confirmação.

\section{Materiais e método: considerações sobre a delimitação do "universo" de pesquisa}

O pensamento de Niklas LUHMANN ilumina também boa parte do processo de escolha do critério estritamente metodológico para o manejo do material teórico adequado a ser utilizado nesta pesquisa, especificamente, a saber: a escolha dos textos doutrinários fundamentais e, portanto, obrigatórios à investigação do objeto acima definido, isto é, o debate doutrinário acerca do princípio da supremacia do interesse público sobre o particular no direito administrativo brasileiro.

Explica-se: quando se elege qualquer debate doutrinário como objeto de pesquisa, parece lógico que esta deva ser realizada com base em sua natural e necessária fonte de consulta, que é a própria produção doutrinária pertinente ao tema do debate então investigado. No entanto, vê-se que o imperativo da pertinência temática torna-se problemático sempre que este debate está a versar sobre uma questão tão relevante, plurívoca e abrangente como é a encartada pela expressão "interesse público" em relação ao direito administrativo. Considerando, pois, que o interesse público exsurge não raramente confundido com a própria ideia de direito administrativo, é de se constatar que, no limite, de uma forma ou de outra, todos os integrantes da doutrina administrativista produzem, bibliograficamente, elementos teóricos mais ou menos relacionados com a noção de interesse público.

É obviamente necessário delimitar este universo que, na teoria de Niklas LUHMANN, está localizado no sistema científico e funciona através de uma linha de comunicação baseada em publicações técnicas e especializadas. Sabe-se que embora a participação seja aberta para todas as pessoas, nem todos reúnem condições dela participar, dada a própria complexidade do conteúdo que é veiculado pela chamada comunicação científica. Isso não significa que o volume de informações cientificamente comunicadas não seja enorme, razão pela qual, o próprio sistema se autorregula, ininterruptamente, por meio de um mecanismo de seletividade, um filtro denominado reputação científica. 
Para Niklas LUHMANN, essa reputação representa um tipo de medida na escala de importância científica atribuída a todos os estudos, visando, justamente, reduzir a arbitrariedade na seleção do que deve ser lido e levado em consideração em cada campo da ciência, ${ }^{2}$ já que somente os trabalhos publicados por autores, instituições ou periódicos de maior reputação influenciam o fluxo da comunicação científica de maneira efetiva. ${ }^{3}$ Como se vê, trata-se de atributo construído propriamente dentro do sistema e é conferido tanto aos cientistas quanto às universidades e institutos de pesquisa e etc. ${ }^{4}$

Segundo o autor, ainda, inúmeras instituições estão, no sistema científico, a serviço do processamento da reputação científica, notadamente, com entregas de prêmios, promoções de homenagens, assim como outros tipos de laudatio. ${ }^{5}$ Claro que dentro deste sistema existem também as "reputações de conveniência", as "ações entre amigos" e as interferências de cunho político e ou econômico-financeiro que podem realmente ocorrer e quando ocorrem, reduzem a potencialidade do sistema científico. ${ }^{6}$ São, por isso, limitações que devem ser coibidas por normas de observação que se voltem não apenas ao nome entenda-se: currículo, biografia, histórico acadêmico - do cientista, mas também ao objeto de cada estudo e principalmente ao valor das descobertas e das teses propostas em cada debate. ${ }^{7}$

Isto posto, entende-se que a pesquisa sobre o debate doutrinário acerca do princípio da supremacia do interesse público sobre o particular no direito administrativo brasileiro impõe a investigação dos textos que, produzidos pela doutrina brasileira, contemplem duas regras: 1) discutir, efetivamente, qualquer das questões referentes à supremacia do interesse público sobre o particular, seja na defesa ou na crítica direcionada a este princípio; e 2) designar estudo que desfrute da aceitação por parte da chamada comunidade acadêmica ou científica.

Para concretizar as regras acima estipuladas, esta pesquisa explora as informações veiculadas por, essencialmente, quatro tipos de material: 1) monografias sobre

\footnotetext{
${ }^{2}$ Cf. Niklas LUHMANN. La ciencia de la sociedad. p. 177.

${ }^{3}$ Cf. Niklas LUHMANN. La ciencia de la sociedad. p. 254.

${ }^{4}$ Cf. Niklas LUHMANN. La ciencia de la sociedad. p. 178.

${ }^{5}$ Cf. Niklas LUHMANN. La ciencia de la sociedad. p. 178.

${ }^{6}$ Cf. Murilo Rodrigues da Cunha SOARES. Dogmática jurídica entre reflexão e redundância: uma análise luhmanniana da produção acadêmica na área do direito tributário. p. 42.

${ }^{7}$ Cf. Niklas LUHMANN. La ciencia de la sociedad. p. 162.
} 
o tema; 2) obras elaboradas - sobretudo, manuais e cursos - por professores universitários, portanto, de uso consagrado no meio acadêmico; 3) artigos extraídos de obras coletivas coletâneas que sabidamente trazem ensaios que fazem parte deste debate; e 4) artigos extraídos dos periódicos técnicos e especializados, publicados no campo do saber jurídico. Deste modo, pode-se dizer que nos quatro itens ora enunciados, encontra-se toda a produção doutrinária obrigatória para a investigação do objeto da presente pesquisa.

Quanto ao levantamento de todos os ensaios pertinentes ao debate, veiculados por periódicos jurídicos, utilizou-se a base de dados mantida pela Biblioteca da Faculdade de Direito da Universidade de São Paulo - o sistema IUSDATA -, tendo por critério a busca de artigos com a expressão "supremacia do interesse público" contida no título; e, em complemento, fora realizado o mesmo procedimento para as expressões "primazia do interesse público", "prevalência do interesse público", "predominância do interesse público" e "superioridade do interesse público". Como resultado, o sistema disponibilizou para a primeira opção de busca, 40 artigos; para a segunda opção, 2 artigos; e para as demais opções, nenhum artigo fora disponibilizado. Do total de 42 artigos, portanto, uma última filtragem mostrava-se necessária, de modo que, primeiramente, atentou-se para as ocorrências repetidas, isto é, para os estudos publicados por mais de uma vez, em diferentes periódicos; e, ao final, tratou-se de identificar também os artigos que, apesar de tratarem do princípio da supremacia do interesse público sobre o particular, não diziam respeito ao seu debate, ora por abordarem o tema em face de outras questões ou institutos, ora por, eventualmente, por tratarem de seu exame à luz do aspecto exclusivamente jurisprudencial. $^{8}$

Contudo, para além destes chamados textos doutrinários obrigatórios, definidos em modo de delimitação do universo de pesquisa, esta dissertação, sem embargo, não deixa de explorar as demais e tão diversas fontes doutrinárias nacionais e estrangeiras, o que o faz, basicamente, como recurso de apoio para algumas frentes paralelas, tais como o exame do desenvolvimento do princípio da supremacia do interesse público sobre o particular ao longo da história pela doutrina administrativista brasileira ou, ainda, como

\footnotetext{
${ }^{8}$ Sem embargo, registre-se a existência de publicações muito interessantes com esse tipo de proposta e que aqui não foram utilizadas apenas em razão do recorte metodológico proposto. É o caso, por exemplo, de: Paulo Roberto Ferreira MOTTA. A supremacia do interesse público (e a sua indisponibilidade) e os direitos fundamentais: o caso Glória Trevi. in A\&C-Revista de Direito Administrativo \& Constitucional, $\mathrm{n}^{\circ} .40 . \mathrm{p}$. 251-269.
} 
auxílio na construção de algumas linhas de pensamento bastante úteis no estudo das argumentações contrárias ou a favor a este princípio, por exemplo. Neste segundo caso, vale dizer, são utilizadas, principalmente, obras de direito constitucional, filosofia jurídica e teoria geral do direito.

\section{Estrutura e formatação: considerações sobre a delimitação dos aspectos formais de pesquisa}

Entre o presente intróito e as conclusões arroladas ao final, esta dissertação segue estruturada por duas partes centrais, preenchidas com três capítulos cada, sendo que estes estão desmembrados em tópicos sequenciais.

Justifica-se a divisão em duas partes porque dupla é a relação deste trabalho com o seu objeto, especificamente, quando entende ser indispensável descrevê-lo antes de investigá-lo. Daí o corte, para que a primeira parte trate do objeto investigado e a segunda cuide da investigação do objeto.

Sendo assim, pode-se dizer que a ordenação dos três primeiros capítulos desempenha um papel primordialmente didático, já que, posto de forma sucinta, o primeiro capítulo enfoca a doutrina administrativista brasileira; o segundo capítulo relaciona o princípio da supremacia do interesse público sobre o particular com a doutrina administrativista brasileira; e o terceiro capítulo apresenta o debate acerca do princípio da supremacia do interesse público sobre o particular promovido pela doutrina administrativista brasileira.

Há, nisso, uma proposital - porquanto necessária - gradação da carga informativa entabulada na sequência destes três capítulos. O intuito - bem sucedido ou não - é o de colocar o leitor "dentro" do debate doravante destrinchado por meio de três dimensões teóricas de análise, desenvolvidas, então, na segunda parte do trabalho.

A dissertação prossegue, portanto, com o quarto capítulo dissertado, que traz a primeira dimensão de análise do debate e trata das divergências teóricas acerca da noção jurídica de interesse público; seguido, logicamente, pelo quinto capítulo, que é sede de desenvolvimento da segunda dimensão de análise do debate, com as divergências teóricas 
que problematizam o caráter principiológico da supremacia do interesse público sobre o particular; sendo finalizada pelo sexto capítulo, correspondente à terceira dimensão de análise, a versar sobre as divergências teóricas existentes quanto à centralidade do princípio da supremacia do interesse público sobre o particular no ordenamento jurídico brasileiro em potencial situação de compatibilidade ou incompatibilidade com o princípio da dignidade da pessoa humana, bem como com os direitos fundamentais do homem e com a teleologia democrática advinda da constituição federal de 1988.

Já no que diz respeito aos procedimentos formais utilizados no desenvolvimento da pesquisa, duas considerações devem ser gravadas. A primeira delas é que, em razão da própria característica do objeto dissertado, optou-se por prestigiar o recurso das citações diretas. A ideia, naturalmente, é a da preservação, na maior medida possível, do sentido original de todas as manifestações doutrinárias examinadas. Neste sentido, anote-se que nenhuma grafia colocada entre aspas fora alterada, nem formalmente. Isso significa, inclusive, que qualquer palavra expressa em itálico, negrito ou grifada, assim está porque assim fora transcrita da obra consultada. E a segunda, em relação à forma de registro destas citações nas notas de rodapé, cumprindo esclarecer que, especialmente para facilitar o reconhecimento da fonte por parte do leitor, optou-se por evitar as expressões do tipo "op. cit", “idem". “ibidem” etc., preferindo sempre repetir, em cada nota, os dados da obra referida. 
PRIMEIRA PARTE: DO OBJETO INVESTIGADO 


\section{EXPLICAÇÕES NECESSÁRIAS ACERCA DO PROBLEMA DOUTRINÁRIO DO PRINCÍPIO DA SUPREMACIA DO INTERESSE PÚBLICO SOBRE O PARTICULAR NO DIREITO ADMINISTRATIVO BRASILEIRO}

\section{1. "Desenho" da problematização proposta}

Em sede introdutória, a delimitação do tema mostrou que esta dissertação não examina o princípio da supremacia do interesse público sobre o particular, mas, sim, o debate doutrinário travado acerca deste princípio no direito administrativo brasileiro.

Antes de passar a examinar o objeto da pesquisa acima mencionado, cabe neste capítulo, contudo, demonstrar quais linhas tracejam o princípio da supremacia do interesse público sobre o particular, desenhando-o como um problema de caráter dogmático e, sobretudo, doutrinário.

Conceber as razões pelas quais determinadas questões jurídicas devem ser desenvolvidas, fundamentalmente, no âmbito doutrinário é vital para a organicidade do direito, em especial, do direito administrativo, bem como para a evolução deste, em constante intercâmbio com as suas fontes.

Por este caminho, o ponto de partida é um breve olhar lançado sobre a palavra problema, notando que a primeira das definições trazidas pelo dicionário HOUAISS para este verbete é "assunto controverso, ainda não satisfatoriamente respondido, em qualquer campo do conhecimento, e que pode ser objeto de pesquisas científicas ou discussões acadêmicas"; ${ }^{9}$ e que a definição equivalente, encontrada no dicionário AURÉLIO - apenas para que não se fixe uma única fonte definidora desta palavra -, é "[q]uestão não solvida e que é objeto de discussão, em qualquer domínio do conhecimento". ${ }^{10}$

No campo do conhecimento jurídico, Ronald DWORKIN problematiza as questões, basicamente, por meio de uma distinção entre duas formas pelas quais torna-se

\footnotetext{
${ }^{9}$ Antônio HOUAISS; Mauro de Salles VILLAR. Dicionário Houaiss da língua portuguesa. p. 2301.

${ }^{10}$ Aurélio Buarque de Holanda FERREIRA. Novo Aurélio Século XXI: o dicionário da língua portuguesa. p. 1640.
} 
possível divergir acerca de uma proposição jurídica. ${ }^{11}$ Por esta distinção, segundo o seu autor, as divergências no direito devem ser classificadas como empíricas e teóricas: ${ }^{12}$

\begin{abstract}
"Agora podemos distinguir duas maneiras pelas quais advogados e juízes poderiam divergir a propósito da verdade de uma proposição jurídica. Eles poderiam estar de acordo sobre os fundamentos do direito - sobre quando a verdade ou a falsidade de outras proposições mais conhecidas torna uma proposição jurídica específica verdadeira ou falsa -, mas poderiam divergir por não saberem se, de fato, aqueles fundamentos foram observados em um determinado caso. (...). Poderíamos dar a isso o nome de divergência empírica sobre o direito. Ou eles poderiam discordar quanto aos fundamentos de direito, sobre quais outros tipos de proposições, quando verdadeiras, tornam verdadeira uma certa proposição jurídica. (...). Poderíamos dar a isso o nome de divergência "teórica" sobre o direito". 13
\end{abstract}

Como se vê, portanto, na síntese do pensamento desenvolvido por Ronald DWORKIN, divergências empíricas no direito são as controvérsias existentes a propósito das questões de fato, ao passo que as divergências teóricas no direito compreendem as dúvidas pertinentes aos fundamentos de direito, quando da análise de determinada proposição jurídica.

Emoldurado por este quadro de análise, afirma-se que o princípio da supremacia do interesse público sobre o particular suscita uma divergência empírica quando juristas discordam quanto ao cabimento de sua aplicação diante da situação fática apresentada no caso concreto; por outro modo, suscita uma divergência teórica quando discordam acerca dos aspectos conceituais e do valor metodológico inerentes a este princípio dentro do direito administrativo, para que ele possa ser aplicado.

Ainda dentro deste quadro, Ronald DWORKIN ensina que "[a] divergência empírica sobre o direito quase nada tem de misteriosa. (...) Mas a divergência teórica no direito, a divergência quanto aos fundamentos do direito, é mais problemática". ${ }^{14}$ Por

\footnotetext{
${ }^{11}$ Cf. Ronald DWORKIN. O Império do Direito. p. 7.

${ }^{12}$ Cf. Ronald DWORKIN. O Império do Direito. p. 8.

${ }^{13}$ Ronald DWORKIN. O Império do Direito. p. 7-8.

${ }^{14}$ Cf. Ronald DWORKIN. O Império do Direito. p. 8.
} 
conseguinte, ensina também que à resolução dos problemas dos fundamentos de direito dedicam-se os acadêmicos e os doutrinadores da comunidade jurídica. ${ }^{15}$

O conteúdo divergente dos fundamentos de direito é considerado mais problemático que o das questões de fato porque alcança pontos intrínsecos à sistematização do direito como ciência ou das ciências que estudam o direito. ${ }^{16}$ Para Niklas LUHMANN, isso ocorre porque a dogmática jurídica encontra-se inserida dentro do sistema jurídico, ${ }^{17}$ desempenhando uma função imanente a este sistema ${ }^{18}$ e operando, nas palavras de Luis Alberto WARAT, como "o código predominante da comunicação normativa". ${ }^{19}$

Quanto à dedicação dos doutrinadores ao estudo dos pontos que, conforme acima referido, estão imbricados à sistematização do direito como ciência ou das ciências que estudam o direito, Lafayette de Azevedo PONDÉ assinala que "[n]o Direito Administrativo, mais talvez do que em qualquer outro campo dos estudos jurídicos, a doutrina é o fio condutor de sua elaboração e da sistematização de seus conceitos e categorias, como um todo orgânico". ${ }^{20}$

Dogmática jurídica e doutrina, embora não designem significados idênticos, ${ }^{21}$ são expressões geralmente bem aproximadas pela teoria geral do direito brasileiro. Essa

\footnotetext{
${ }^{15}$ Cf. Ronald DWORKIN. O Império do Direito. p. 137.

${ }^{16}$ Seguindo a posição de Eros Roberto GRAU, entendo que o direito não é uma ciência, mas, sim, o objeto de estudo de diversas ciências do direito. Assim diz o autor: "O direito não é uma ciência. O direito é estudado e descrito; é, assim, tomado como objeto de uma ciência, a chamada ciência do direito. (...) Sucede que não há apenas uma ciência do direito, porém um conjunto de ciências do direito". in Eros Roberto GRAU. O direito posto e o direito pressuposto. p. 36-37.

17 “(...) as condições do juridicamente possível, em concreto as possibilidades da construção jurídicas de casos jurídicos. (...) Assim, a Dogmática jurídica constitui o ponto mais elevado e mais abstrato das possíveis determinações de sentido do direito dentro do próprio sistema jurídico". Tradução livre. Na fonte consultada: “(...) las condiciones de lo juridicamente posible, em concreto las possibilidades de la construcción jurídica de casos jurídicos. (...). Así , la dogmática jurídica constituye el plano más elevado y más abstracto de las posibles determinaciones de sentido dentro del próprio sistema jurídico”. in Niklas LUHMANN. Sistema jurídico y dogmática jurídica. p. 34.

${ }^{18}$ Cf. Niklas LUHMANN. Sistema jurídico y dogmática juridica. p. 20. Sem prejuízo, tal função é explicada por José Rodrigo RODRIGUEZ da seguinte forma: “a dogmática jurídica cumpre sua função na condição de sistema de representações e de raciocínios estandardizados partilhados pelos participantes do sistema jurídico". in José Rodrigo RODRIGUEZ. A persistência do formalismo: uma crítica para além da separação de poderes., in José Rodrigo RODRIGUEZ; Carlos Eduardo Batalha da Silva e COSTA; Samuel Rodrigues BARBOSA (org.). Nas fronteiras do formalismo: a função social da dogmática jurídica hoje. p. 159.

${ }^{19}$ Luis Alberto WARAT. Mitos e teorias na interpretação da lei. p. 48., apud Vera Regina Pereira de; ANDRADE. Dogmática e sistema penal: em busca da segurança jurídica prometida. p. 76.

${ }^{20}$ Lafayette de Azevedo PONDÉ. A doutrina e a jurisprudência na elaboração do direito administrativo., in Revista de Direito Administrativo, n. ${ }^{\circ}$ 196. p. 92.

${ }^{21}$ O desenvolvimento conceitual de cada um dos termos acima mencionados será realizada no próximo tópico deste capítulo.
} 
aproximação é explicitada por Miguel REALE ao definir que "[o]s modelos doutrinários são também denominados modelos dogmáticos (...)", ${ }^{22}$ de modo que a produção normativa não pode ser considerada plena “(...) sem ter, como antecedente lógico e necessário, o trabalho científico dos juristas e muito menos atualizar-se sem a participação da doutrina". 23

Sendo assim, voltando para o ramo do direito administrativo, defluem das linhas que desenham a problematização proposta, as seguintes constatações:

Em primeiro lugar, vê-se, de fato, que o princípio da supremacia do interesse público sobre o particular é um problema porque é um assunto controverso, possivelmente ainda não resolvido de maneira satisfatória e que, por isso, tem sido objeto de pesquisas científicas e discussões acadêmicas.

Em segundo lugar, esse problema situa-se no sistema jurídico, mais precisamente, em uma de suas instâncias comunicacionais internas, a dogmática jurídica, que se desenvolve cientificamente através das pesquisas e das discussões acadêmicas, que são realizadas pela doutrina. ${ }^{24}$

E por fim, a controvérsia - ou divergência, para usar o mesmo termo empregado por Ronald DWORKIN - deste problema é preponderantemente teórica, vez que o princípio da supremacia do interesse público sobre o particular é o fundamento de direito administrativo que, sendo objeto de pesquisas científicas e discussões acadêmicas, motiva esse debate doutrinário no direito administrativo brasileiro.

\subsection{Questão terminológica: dogmática administrativista ou doutrina administrativista?}

Uma rápida leitura dos textos que perfazem o debate brasileiro sobre o princípio da supremacia do interesse público sobre o particular permite verificar que tanto a expressão dogmática jurídica quanto a expressão doutrina - geralmente colocada sem o

\footnotetext{
${ }^{22}$ Miguel REALE. Lições preliminares do direito. p. 177.

${ }^{23}$ Miguel REALE. Lições preliminares do direito. p. 177.

${ }^{24}$ Permitindo também que o sistema jurídico possa se comunicar com o sistema científico dentro da dinâmica da teoria dos sistemas. Cf. Niklas LUHMANN. Sistema jurídico y dogmática juridica. p. 34.
} 
complemento do adjetivo "jurídica" - são utilizadas indistintamente, de forma livre e sem justificativas acerca da terminologia eleita por parte dos autores.

À guisa de exemplo, destaca-se o artigo "Repensando o "princípio da supremacia do interesse público sobre o particular",", ${ }^{25}$ de Humberto Bergmann ÁVILA, que é, vale dizer, o artigo inaugural do debate ${ }^{26}$ que constitui o objeto desta pesquisa.

Neste trabalho, num primeiro momento, o mencionado autor utiliza a expressão “dogmática jurídica brasileira - do Direito Administrativo e também do Direito Tributário" para se referir aos estudiosos do direito público, dentre eles, Celso Antônio Bandeira de Mello, que "sustenta[m] que dentre aqueles princípios que regulam a relação entre o Estado e o particular está o "princípio da supremacia do interesse público sobre o particular""; ${ }^{27}$ e em momento posterior, utiliza a palavra "doutrina" para dizer que o princípio da supremacia do interesse público sobre o particular, tal como vem sendo descrito por esses mesmos estudiosos do direito público, não se identifica com o bem comum. $^{28}$

No tópico inicial do presente capítulo, afirmou-se que dogmática jurídica e doutrina são expressões que não designam significados idênticos. Trata-se, todavia, de conceitos similares, à medida que o termo dogmática possa ser definido como um tipo de racionalidade jurídica voltada para a criação de condições para a decidibilidade dos conflitos sociais. ${ }^{29}$ Neste passo, Carlos Eduardo Batalha da Silva e COSTA a define como “(...) um conjunto de teorias operacionais que buscam influenciar os comportamentos sociais (...)" manifestando-se de duas maneiras: a primeira, “(...) na demarcação do sistema jurídico (traçando uma linha divisória entre Direito e sociedade) (...)”; e a segunda, “(...) na promoção do Direito como força unificadora (o que rearticula o sistema jurídico com seu

${ }^{25}$ Humberto Bergmann ÁVILA. Repensando o "princípio da supremacia,do interesse público sobre o particular". in Revista Trimestral de Direito Público , n. 24. p. 159-180.

${ }^{26}$ A história deste debate será relatada em tópico específico, no terceiro capítulo desta pesquisa infra.

${ }^{27}$ Humberto Bergmann ÁVILA. Repensando o "principio da supremacia,do interesse público sobre o particular". in Revista Trimestral de Direito Público , n.24. p. 159.

${ }^{28}$ Cf. Humberto Bergmann ÁVILA. Repensando o "princípio da supremacia,do interesse público sobre o particular”. in Revista Trimestral de Direito Público , n.. 24. p. 160.

${ }^{29}$ Cf. Juliano Souza de Albuquerque MARANHÃO. O discurso da dogmática jurídica, in José Rodrigo RODRIGUEZ; Carlos Eduardo Batalha da Silva e COSTA; Samuel Rodrigues BARBOSA (org.). Nas fronteiras do formalismo: a função social da dogmática jurídica hoje. p. 77. 
mundo circundante)" ${ }^{30}$ Contudo, essa racionalidade ou conjunto de teorias operacionais é composta por uma série de preceitos e institutos jurídicos - os chamados dogmas -, que são desenvolvidos ao longo da história, não só por construção doutrinária, mas, também, jurisprudencial. $^{31}$

Esse trabalho desenvolvido tanto pela doutrina quanto pela jurisprudência é assim descrito por Tercio Sampaio FERRAZ JR.:

"Na verdade, a doutrina, como a jurisprudência, aliás com um grau de objetividade maior, pode ser responsável pelo aparecimento de standards jurídicos, fórmulas interpretativas gerais que resultam de valorações capazes de conferir certa uniformidade a conceitos vagos e ambíguos como mulher honesta, justa causa, trabalho noturno, ruído excessivo etc". ${ }^{32}$

Alguns autores, destarte, exaltam a importância da jurisprudência dentro da dogmática, isto é, na construção da referida racionalidade jurídica para a criação de condições para a decidibilidade dos conflitos sociais. É o caso da abaixo transcrita lição de Danilo KNIJNIK:

"Como decorrência da causa dogmática, mas também à luz dos endereços exegéticos decorrentes da causa hermenêutica, a própria jurisprudência vai assumir, assim, um papel diferenciado, elevando as Cortes Superiores ao plano das fontes do direito. Assim, já não se poderá dizer, efetivamente, que o Superior Tribunal de Justiça simplesmente "declare" a solução mais adequada para determinados casos ou assuntos submetidos à sua jurisdição. Em realidade, ele também estará criando ou adicionando algo de novo do ponto de vista da formulação das regras jurídicas. Assim, o precedente judiciário, à vista da legislação moderna, assume um papel decisivo". ${ }^{33}$

\footnotetext{
${ }^{30}$ Carlos Eduardo Batalha da SILVA e COSTA. A filosofia jurídica como saber metaideológico: anotações a partir da função social da dogmática no enfoque de Tércio Sampaio Ferraz Jr., in José Rodrigo RODRIGUEZ; Carlos Eduardo Batalha da Silva e COSTA; Samuel Rodrigues BARBOSA (org.). Nas fronteiras do formalismo: a função social da dogmática jurídica hoje. p. 147.

${ }^{31}$ Cf. César FIUZA. Direito civil: curso completo. p. 31.

${ }^{32}$ Tercio Sampaio FERRAZ JR. Introdução ao estudo do direito: técnica, decisão, dominação. p. 247.

${ }^{33}$ Danilo KNIJNIK. O recurso especial e a revisão da questão de fato pelo Superior Tribunal de Justiça. p. 54.
} 
Ocorre que se de um lado, como se viu, a dogmática jurídica não resulta apenas da construção doutrinária; de outro, a doutrina também não se constrói utilizando exclusivamente o enfoque dogmático, já que os preceitos e institutos desenvolvidos pelos doutrinadores do direito não são simples construções lógicas, desprovidas de conteúdo histórico, filosófico, econômico, político e social. ${ }^{34}$

O enfoque dogmático contrapõe-se ao enfoque zetético na investigação dos fenômenos jurídicos. ${ }^{35}$ Em modo comparativo, a investigação dogmática é mais fechada porque parte dos dogmas, ou seja, dos preceitos e institutos que são estudados dentro do sistema jurídico e estão voltados às condições criadas por este sistema para a decisão dos conflitos sociais; já a investigação zetética é mais aberta porque tem a preocupação de ampliar, para além do sistema jurídico, as dimensões do fenômeno investigado, estudandoo em profundidade e sem a preocupação com o problema da decidibilidade. ${ }^{36}$

Como ensina Tercio Sampaio FERRAZ JR., "é preciso reconhecer que o fenômeno jurídico, com toda a sua complexidade, admite tanto o enfoque zetético, quanto o enfoque dogmático, em sua investigação". ${ }^{37}$ O trabalho da doutrina, convém lembrar, sobretudo no que diz respeito ao debate acerca do princípio da supremacia do interesse público sobre o particular, é preponderantemente dogmático, ${ }^{38}$ porém não dissociado da zetética.

Por isso, a presente dissertação utilizará a terminologia doutrina administrativista ou doutrina de direito administrativo - e não dogmática administrativista ou dogmática de direito administrativo - toda vez que se referir ao trabalho científico realizado pelos estudiosos do direito administrativo; bem como utilizará a terminologia debate doutrinário

\footnotetext{
${ }^{34}$ Rafael BIELSA explica que se assim fossem, estariam reduzidos a um conjunto de definições meramente formais e, portanto, insuficientes para constituírem regras jurídicas. Cf. Rafael BIELSA. Metodología jurídica. p. 76.

${ }^{35}$ Consoante teoria desenvolvida por Theodor VIEWEG e difundida no Brasil por Tercio Sampaio FERRAZ JR., Neste sentido, ver Alexandre Araújo COSTA. Introdução ao direito: uma perspectiva zetética das ciências jurídicas. p. 158-159.

${ }^{36}$ Para aprofundamento acerca da contraposição entre os enfoques zetético e dogmático, ver Tercio Sampaio FERRAZ JR. Introdução ao estudo do direito: técnica, decisão, dominação. p. 49-44.

${ }^{37}$ Tercio Sampaio FERRAZ JR. Introdução ao estudo do direito: técnica, decisão, dominação. p. 43. E no mesmo sentido, porém, em outra obra: "Entre elas [zetética e dogmática], não há uma separação radical: ao contrário, elas se entremeiam, referem-se mutuamente, às vezes se opõem, outras vezes colocam-se paralelamente, estabelecendo um corpo de possibilidades bem diversificado". in Tercio Sampaio FERRAZ JR.; Função social da dogmática jurídica. p. 93.

38 Razão pela qual as expressões dogmática jurídica e doutrina são aproximadas pela teoria geral do direito brasileiro, conforme, aliás, já demonstrado no tópico anterior.
} 
ou debate da doutrina - e não debate dogmático ou debate da dogmática - toda vez que se referir à discussão travada entre os estudiosos do direito administrativo sobre o princípio da supremacia do interesse público sobre o particular.

\subsection{O papel da doutrina na formação e evolução do direito administrativo}

Há, sem dúvidas, diversas acepções possíveis para o uso da palavra doutrina. Quando esta dissertação vincula a expressão doutrina jurídica ao trabalho científico realizado pelos estudiosos do direito, assim o faz, como se vê, em sentido convergente à terminologia "Direito Científico", criada por Friederich Karl von SAVIGNY. ${ }^{39}$

A doutrina, na acepção jurídico-científica da palavra, portanto, é constituída pelo conjunto da produção intelectual dos juristas, que se dedicam ao conhecimento teórico do direito $^{40}$ e emitem suas opiniões e ensinamentos através da publicação de manuais didáticos, tratados, monografias e etc. ${ }^{41}$

A sua presença no elenco das fontes do direito, embora controvertida, ${ }^{42}$ não a priva, como pondera Miguel REALE “(...) de seu papel relevantíssimo no desenrolar da experiência jurídica ${ }^{43}$ ”, nem faz com que ela “(...) deix[e] de ser uma das molas propulsoras, e a mais racional das forças diretoras, do ordenamento jurídico". ${ }^{44}$

Paulo NADER mostra que não obstante a doutrina tenha seu desenvolvimento localizado no plano teórico, ela influencia a prática do mundo jurídico de diversas formas: primeiro, “(...) oferecendo valiosos subsídios ao legislador, na elaboração dos documentos legislativos", já que "[s]e ao legislador compete a atualização do Direito Positivo, a tarefa

\footnotetext{
${ }^{39}$ Apud José CRETELLA JR.. Dicionário de direito administrativo. p. 204-205. Oliveiros LITRENTO. A doutrina na ordem jurídica. p. 13. Miguel REALE. Lições preliminares do direito. p. 175. Entre outros.

${ }^{40}$ Cf. Dimitri DIMOULIS. Manual de introdução ao estudo do direito. p. 220.

${ }^{41}$ Cf. Dimitri DIMOULIS. Manual de introdução ao estudo do direito. p. 221.

${ }^{42}$ Neste ponto, a posição a que me filio é a apresentada por Edmir Netto de ARAÚJO, para quem a "(...) a doutrina é considerada, também no âmbito do Direito Administrativo, como fonte mediata do Direito, que se faz sentir especialmente como fonte supletiva de omissões ou deficiências da lei, como repositório dos princípios e conceitos do Direito e principalmente como atividade interpretativa dos textos legais e sua aplicação". in Edmir Netto de ARAÚJO. Curso de direito administrativo. p. 64.

${ }^{43}$ Miguel REALE. Lições preliminares do direito. p. 176.

${ }^{44}$ Miguel REALE. Lições preliminares do direito. p. 178.
} 
de investigar os princípios e institutos necessários é própria dos juristas (...)" e "[s]e estes falham em sua missão, se não propõem modelos concretos, o legislador não alcançará o seu intento de modernizar o sistema jurídico"; segundo, participando da “(...) formação de normas costumeiras, relativas a certos negócios jurídicos (...)” que “(...) decorre[m] de prévio aconselhamento dos juristas"; terceiro, beneficiando o trabalho de advogados e juízes com a sistematização e interpretação das normas jurídicas, já que "[t]anto a arte de postular em juízo quanto a de julgar requerem o conhecimento do Direito" e "[a] lição dos juristas, apresentada em seus tratados e monografias, é uma fonte valiosa de orientação, capaz de propiciar embasamento científico ao raciocínio jurídico"; e quarto, facilitando o ensino do direito nas universidades, tendo em vista que "[e]nquanto as ciências da natureza possibilitam a investigação em laboratórios, a compreensão do fenômeno jurídico se alcança pelo estudo e reflexão das teorias expostas em livros". 45

No campo do direito administrativo, o papel desempenhado pela doutrina é descrito por Jean RIVERO da seguinte forma:

“(...) [A]o agir por persuasão sobre a autoridade competente para emitir a norma, a doutrina desempenhou um papel primordial, se bem que indirecto, na elaboração do direito administrativo; um grande número de regras que a lei ou a jurisprudência fizeram passar para o direito positivo têm a sua origem na opinião dos autores. Este papel exerce-se por meio de obras e artigos jurídicos e através do ensino; nestes dois aspectos é sobretudo assumido pelos docentes das Faculdades de Direito e por numerosos membros dos Tribunais administrativos que, a par das suas funções oficiais, escrevem ou ensinam a título privado. A tarefa da doutrina, particularmente importante num direito não codificado e largamente jurisprudencial como é o direito administrativo, consiste, por um lado, em organizar esse direito de forma sistemática, extraindo os princípios que inspiram as soluções legislativas e jurisprudenciais, por outro, em divulgar o direito assim organizado - que, sem isso, seria difícil de conhecer por fim, em apreciar esse direito do triplo ponto de vista de sua coerência, da sua adequação ao fim social que persegue e da sua conformidade com a justiça, preparando assim o caminho às reformas de que surgirá o direito de amanhã. Nesta tripla função a doutrina assume um papel insubstituível. Sem o seu esforço de sistematização, em vez de um direito administrativo constituído em disciplina inteligível, existiria apenas uma justaposição de textos e de decisões

\footnotetext{
${ }^{45}$ Paulo NADER. Introdução ao estudo do direito. p. 183-184.
} 
desprovidas de coerência, e por isso mesmo inassimilável e destituída de eficácia". ${ }^{46}$

Isso posto, é preciso reconhecer que no contexto evolutivo do direito administrativo a doutrina desempenhou seu papel de forma ainda mais intensa, sobretudo com a elaboração - em trabalho conjunto com a jurisprudência, é verdade - de diversas teorias fundamentais, que depois de sistematizadas pelos doutrinadores dentro da disciplina, passaram a ser acatadas pelos legisladores e consequentemente consagradas pelo direito positivo ${ }^{47}$.

Tal fenômeno é explicado por Manuel María DIEZ:

"Essa maior importância [da doutrina] no direito administrativo que no direito privado se explica pelas seguintes razões: no direito privado existem codificações que dão solução concreta para o maior número de questões que possam se apresentar, de tal forma que ao intérprete basta consultar as disposições do código correspondente para resolver o caso em particular. Estas codificações foram possíveis graças a lenta elaboração, através de muitos séculos, que permitiram ao direito privado alcançar uma sistematização quase perfeita. Essa circunstância não ocorreu no campo do direito administrativo, já que se trata de uma disciplina cuja formação como ramo autônomo do direito é recente: data do final do século passado. Ademais, pela própria natureza das atividades que regula, é variável e cambiante segundo as épocas e os países. Por isso não há, em nenhum país, um verdadeiro código de direito administrativo. (...) Por fim, as leis publicadas vão se modificando ao cabo de poucos anos para adaptarse a novas realidades e em muitos aspectos faltam textos legais ou os que existem são fragmentados". 48

\footnotetext{
${ }^{46}$ Jean RIVERO. Direito Administrativo. p. 82-83.

47 Cf. Manuel María DIEZ. Derecho administrativo. p. 512. Diz o autor: "Um exemplo que justifica a importância que tem a doutrina no campo do direito administrativo vem da teoria geral dos atos administrativos. A construção, neste caso, é em quase todos os países, de origem jurisprudencial e doutrinária, já que somente existem texto legais isolados". Tradução livre. No original: "Um ejemplo que justifica la importância que tiene la doctrina en el campo del derecho administrativo, lo brinda la teoria general de los actos administrativos. La construcción en este caso es, en casi todos lós países, de origen jurisprudencial y doctrinario, ya que solamente existen textos legais aislados”. in Manuel María DIEZ. Derecho administrativo. p. 512.

${ }^{48}$ Tradução livre. No original: "Esa mayor importancia en el que em el derecho privadose explica por las siguientes razones: en el derecho privado, existen grandes codificaciones que dan solución concreta al mayor número de cuestionesque puedan presentarse, en forma tal que al intérprete le basta consultar las disposiciones del código correspondiente para resolver um caso particular. Estas codificaciones, en el derecho privado, han sido posibles debido a la lenta elaboración, a través de muchos siglos, que há
} 
As duas passagens acima colacionadas demonstram, em consonância com toda a linha de pensamento até aqui entabulada, a importância do papel desempenhado pela doutrina, principalmente, no que diz respeito à sistematização do direito administrativo, dele extraindo os postulados que o caracterizam como disciplina jurídica, dotada de autonomia científica e metodologia diferenciada. ${ }^{49} \mathrm{O}$ fato do direito administrativo não ser codificado, no sentido de lei única e ordenadora de regras gerais definidas em um mesmo texto ${ }^{50}$, permite que seus princípios sejam desenvolvidos pela dialética estabelecida no seio da comunis opinium doctorum, através cultores do "Direito Científico", os integrantes da doutrina administrativista.

\subsection{O problema doutrinário do princípio da supremacia do interesse público sobre o particular no direito administrativo brasileiro}

No Brasil, o direito administrativo desenvolveu-se praticamente com a mesma lógica evolutiva acima relatada, no tópico anterior. A grande influência da doutrina na formação do direito administrativo brasileiro consta no relato de Maria Sylvia Zanella DI PIETRO, ao lembrar que malgrado o direito positivo já houvesse aqui previsto a unidade de jurisdição e o princípio da legalidade, foi pelo trabalho da doutrina e sua forte inspiração no direito continental europeu que os tribunais começaram a reconhecer e aplicar teorias e princípios não consolidados pelo direito positivo, senão em fase posterior da evolução do direito administrativo brasileiro. ${ }^{51}$

\footnotetext{
permitido alcanzar uma sistematización casi perfecta. Esta circunstancia no ocurre en el campo del derecho administrativo, ya que se trata de una disciplina cuya formación como rama autônoma del derecho es reciente: fines del siglo passado. Además, por la propia naturaleza de las actividades que regula, es variable y cambiante según las épocas y los países. De ahí que no haya em ningún país um verdadero código de derecho administrativo. (...) Por ló demás, las leyes dictadas se modifican al cabo de pocos a años para adaptarse a la nuevas necesidades, y en muchos aspectos faltan textos legales o lós que existen son fragmentarios”. in Manuel María DIEZ. Derecho administrativo. p. 512.

${ }^{49}$ Sobre a autonomia científica e a metodologia diferenciada do direito administrativo, ver, especificamente, nesta pesquisa, os tópicos do capítulo seguinte 2.2. e 2.3. infra. Para aprofundamento, consultar a obra de José CRETELLA JR.. Filosofia do direito administrativo, publicada pela editora Forense.

${ }^{50}$ Cf. Lafayette de Azevedo PONDÉ. A doutrina e a jurisprudência na elaboração do direito administrativo, in Revista de Direito Administrativo, n. ${ }^{\circ}$ 196. p. 91.

${ }^{51}$ Cf. Maria Sylvia Zanella DI PIETRO. O direito administrativo brasileiro sob influência dos sistemas de base romanística e da Common Law. in Revista Eletrônica de Direito Administrativo Econômico. no ${ }^{\circ} .8$, p. 5.
} 
Em sequência de raciocínio, Maria Sylvia Zanella DI PIETRO exemplifica, lembrando que temas como o dos contratos administrativos; o dos atos administrativos, com seus vícios e hipóteses de anulação, revogação e convalidação; o da discricionariedade administrativa e o da responsabilidade objetiva do Estado foram teoricamente desenvolvidos e tiveram seus regimes jurídicos construídos pela doutrina administrativista muito antes de serem previstos legalmente, ${ }^{52}$ o que lhe permite, ao cabo de seu pensamento, concluir que o sentido da evolução do direito administrativo brasileiro partiu do trabalho doutrinário para a conseguinte acolhida da jurisprudência e final consagração no direito positivo. ${ }^{53}$

De seu turno, Fernando Dias MENEZES de ALMEIDA estuda a história do direito administrativo brasileiro, apoiando-se na mesma trilha evolutiva:

“(...) [O] Direito administrativo brasileiro, sobretudo nas primeiras décadas do século XX, é antes decorrente de formulação doutrinária, consolidada jurisprudencialmente - tomando-se, na prática, as afirmações da doutrina como dogma -, do que decorrente de produção legislativa, a qual, a seu turno, quando surge, em grande medida é influenciada pelas teorias elaboradas em doutrina e acolhidas na jurisprudência". ${ }^{4}$

Com efeito, lógica semelhante é apresentada por Floriano Peixoto de Azevedo MARQUES NETO quando, neste contexto, compara os sistemas francês e brasileiro de direito administrativo e explica que no caso brasileiro, ao contrário do francês, “(...) a doutrina, e não a jurisprudência, [é] que tem conduzido a constante evolução do Direito Administrativo"; 55 assevera que se na França a doutrina tinha como principal escopo “(...) sistematizar os julgados provenientes dos Tribunais administrativos para, assim, indicar o funcionamento de institutos à luz de precedentes e conferir o estágio de desenvolvimento

\footnotetext{
52 "Muito antes de haver uma lei disciplinando os contratos administrativos (o que só foi feito de forma mais completa pelo Decreto-lei $\mathrm{n}^{\circ} 2.300$, de 1086), nós já aplicávamos tudo o que hoje está no direito positivo". in Maria Sylvia Zanella DI PIETRO. O direito administrativo brasileiro sob influência dos sistemas de base romanística e da Common Law. in Revista Eletrônica de Direito Administrativo Econômico. nº. 8, p. 5-6.

${ }^{53}$ Cf. Maria Sylvia Zanella DI PIETRO. O direito administrativo brasileiro sob influência dos sistemas de base romanística e da Common Law. in Revista Eletrônica de Direito Administrativo Econômico. nº. 8, p. 6.

${ }^{54}$ Fernando Dias MENEZES de ALMEIDA. Contrato administrativo. p. 50-51.

${ }^{55}$ Floriano Peixoto de Azevedo MARQUES NETO. A responsabilidade objetiva das concessionárias de serviço público: a jurisprudência do STF e o papel da doutrina., in Revista de Direito Administrativo Contemporâneo, v. 0. p. 16.
} 
teórico do Direito Administrativo", 56 no Brasil ela constitui, em verdade, "a principal força criativa do direito", 57 razão pela qual, a seu ver, “(...) por aqui a doutrina tem mais influência sobre as decisões jurisprudenciais do que estas influenciam a doutrina". 58

De todo o exposto, novamente, o que figura em destaque é o aspecto científico do trabalho historicamente desempenhado pelos doutrinadores administrativistas, não apenas desenvolvendo e criticando as teorias elaboradas sobre os institutos e os princípios sistematizadores da matéria, mas, também, criando, verdadeiramente, uma normatividade jurídica decorrente da evolução dessas construções doutrinárias.

Elaborar teorias, desenvolvê-las e criticá-las são, dentro deste contexto, ações integrantes do debate acadêmico. Como demonstrado de início, no campo do conhecimento jurídico este debate é desenvolvido pela doutrina e as ações ora mencionadas - elaborar, desenvolver e criticar - ordenam um diálogo de construções teóricas contrapostas com vistas à solução dos problemas normativos, especificamente, na criação de condições de decidibilidade dos conflitos no sistema jurídico. Neste sentido, entendimentos doutrinários são construídos e desconstruídos gerando as chamadas divergências teóricas, de Ronald DWORKIN, porque desvelam dissonâncias acerca dos aspectos conceituais e do valor metodológico dos fundamentos de direito.

Dentro do direito administrativo brasileiro, verifica-se que o princípio da supremacia do interesse público sobre o particular é um fundamento de direito assim problematizado pelo debate doutrinário principalmente à medida que estudos são publicados visando, objetivamente, "desconstruir" as concepções teóricas que sedimentaram o mencionado princípio, no decorrer da história.

\footnotetext{
${ }^{56}$ Floriano Peixoto de Azevedo MARQUES NETO. A responsabilidade objetiva das concessionárias de serviço público: a jurisprudência do STF e o papel da doutrina., in Revista de Direito Administrativo Contemporâneo, v. 0. p. 18.

57 Floriano Peixoto de Azevedo MARQUES NETO. A responsabilidade objetiva das concessionárias de serviço público: a jurisprudência do STF e o papel da doutrina., in Revista de Direito Administrativo Contemporâneo, v. 0. p. 16. Ou nos dizeres de Marcello CAETANO, citado também pelo autor do artigo ora referenciado, considera-se a doutrina "uma força geradora de soluções jurídicas". in Marcello CAETANO. Manual de direito administrativo. t. I. p. 89.

58 Floriano Peixoto de Azevedo MARQUES NETO. A responsabilidade objetiva das concessionárias de serviço público: a jurisprudência do STF e o papel da doutrina., in Revista de Direito Administrativo Contemporâneo, v. 0. p. 16.

59 Exemplo bastante ilustrativo desta situação é o nome da obra coletiva, organizada por Daniel SARMENTO. Interesses públicos versus interesses privados:desconstruindo o princípio da supremacia do interesse público., publicada pela Editora Lumen Juris.
} 
Por este plano, construções e desconstruções teóricas equivalem às chamadas teses e antíteses da dialética hegeliana; o que reveste de utilidade a investigação acerca do conteúdo jurídico-científico ainda oculto pelo hiato existente entre a construção e a desconstrução do princípio da supremacia do interesse público sobre o particular, para que deste conteúdo resulte a sua síntese, ou no sentido da analogia apresentada, a sua potencial reconstrução doutrinária ${ }^{60}$.

Desta feita, repise-se que esta dissertação não investiga, portanto, o princípio da supremacia do interesse público sobre o particular, mas, sim, o debate doutrinário travado acerca deste princípio no direito administrativo brasileiro.

60 “(...) [É] justamente nas preciosas lições dos jovens juristas que se propõem radicalmente a desconstruir o princípio do interesse público que iremos encontrar bases para a construção de sua verdadeira concepção, à luz da melhor doutrina e dos supremos valores fundamentais de nosso próprio ordenamento jurídicoconstitucional, que não podem ser esquecidos nem desrespeitados." In Alice Gonzalez BORGES. Supremacia do interesse público: desconstrução ou reconstrução? in Revista Interesse Público, n. ${ }^{\circ} 37$. p.43. 


\section{A CONSTRUÇÃO DOUTRINÁRIA DO PRINCÍPIO DA SUPREMACIA DO INTERESSE PÚBLICO SOBRE O PARTICULAR NO DIREITO ADMINISTRATIVO BRASILEIRO}

\subsection{O método tópico e as grandes dicotomias do direito}

No capítulo anterior, afirmou-se "o aspecto científico do trabalho historicamente desempenhado pelos doutrinadores administrativistas, não apenas desenvolvendo e criticando as teorias elaboradas sobre os institutos e os princípios sistematizadores da matéria, mas, também, criando, verdadeiramente, uma normatividade jurídica decorrente da evolução de tais construções doutrinárias". ${ }^{61}$

Conforme se depreende do acima posto, teorias jurídicas são construções doutrinárias; pela lição de Miguel REALE, constituem esquemas teóricos reciprocamente correlacionados para a composição sistemática dos fundamentos de direito. ${ }^{62}$

Por esta linha de pensamento e partindo da consideração de que as divergências teóricas no sistema jurídico, conforme também já demonstrado, são as que tratam das dúvidas pertinentes aos fundamentos de direito ${ }^{63}$, torna-se possível assinalar que qualquer divergência teórica potencialmente estabelecida acerca do princípio da supremacia do interesse público sobre o particular seja, portanto, uma divergência que se manifesta, na verdade, em torno de sua concepção dogmática, construída pela doutrina brasileira através dos tempos.

Uma vez compreendida esta ideia, é preciso investigar, agora, o processo de desenvolvimento desta construção doutrinária, isto é, de que maneira a teoria do princípio da supremacia do interesse público sobre o particular - hoje, colocada em debate - foi construída, historicamente, pela doutrina administrativista no direito brasileiro.

Neste passo é importante, primeiramente, retomar outra questão trabalhada no capítulo anterior, referente à preponderância do enfoque dogmático no trabalho da

\footnotetext{
${ }^{61}$ Consultar, no primeiro capítulo desta pesquisa, o tópico 1.4. retro.

${ }^{62}$ Cf. Miguel REALE. Lições preliminares do direito. p. 176.

${ }^{63}$ Consultar, no primeiro capítulo desta pesquisa, o tópico 1.1. retro.
} 
doutrina, sobretudo em seu estudo acerca do princípio da supremacia do interesse público sobre o particular. ${ }^{64}$ Isso porque, em linhas gerais, o enfoque dogmático visa sistematizar o direito, lançando mão de uma série de critérios classificatórios para a adequada alocação teórica dos fenômenos jurídicos investigados. Trata-se dos esquemas teóricos mencionados por Miguel REALE. Por suas palavras, “[t]oda ciência, para ser bem estudada, precisa ser dividida, ter as suas partes claramente discriminadas" $" 65$ e assim, neste contexto, o trabalho da doutrina jurídica consiste em produzir modelos dogmáticos ou esquemas teóricos para determinar "a) como as fontes podem produzir modelos jurídicos válidos; b) que é que estes modelos significam; e c) como eles se correlacionam entre si para compor figuras, institutos e sistemas, ou seja, modelos de mais amplo repertório", ${ }^{66}$

Esse conjunto de classificações com distinções amplas e historicamente desenvolvidas pela dogmática é chamado por Tercio Sampaio FERRAZ JR. de método tópico de raciocínio do jurista. ${ }^{67}$ Com este método, o direito é dividido em lugares comuns, em pontos que representam noções não logicamente rigorosas, mas que auxiliam a organização e orientação coerentes da matéria e por isso são passíveis de discordância e geram teorias dogmáticas diversas, que intentam dominar os problemas de decidibilidade da forma mais coerente e abrangente possível. ${ }^{68}$

Aludidas divisões partem de concepções teóricas bipartidas, de forma a classificar o direito através de grandes chaves binárias para a organização do pensamento. São as chamadas grandes dicotomias do direito.

Tercio Sampaio FERRAZ JR. discorre sobre as grandes dicotomias do direito com as seguintes palavras:

"As grandes dicotomias permitem uma sistematização, no sentido dogmático, isto é, tópico, do direito analiticamente concebido como conjunto de normas. Trata-se, para usar uma terminologia de Kelsen, de uma sistematização estática.

Entenda-se por sistema estático uma organização de normas que leva em conta sua estrutura ou matéria normada (relação autoridade/sujeito, a facti species e a consequência jurídica, as

\footnotetext{
${ }^{64}$ Consultar, no primeiro capítulo desta pesquisa, o tópico 1.2. retro.

${ }^{65}$ Miguel REALE. Lições preliminares do direito. p. 335.

${ }^{66}$ Cf. Miguel REALE. Lições preliminares do direito. p. 176.

${ }^{67}$ Cf. Tercio Sampaio FERRAZ JR. Introdução ao estudo do direito: técnica, decisão, dominação. p. 132.

${ }^{68}$ Cf. Tercio Sampaio FERRAZ JR. Introdução ao estudo do direito: técnica, decisão, dominação. p. 132.
} 
relações que se formam entre os sujeitos). O caráter estático do sistema que se prescinde do processo contínuo de formação, atuação ou desaparecimento das normas, o qual caracteriza uma dinâmica. $\mathrm{O}$ sistema estático concebe o conjunto normativo como um dado, abstração feita de seu câmbio permanente. Não se indaga, por isso, da emissão de normas, sua revogação e da emissão de novas normas: o quadro é estático". 69

Com as grandes dicotomias, a doutrina orienta e organiza - portanto, dogmatiza a sua forma de estudar o direito, variando de acordo com a perspectiva de análise utilizada. Por este meio, a matéria pode ser dividida de diferentes formas, a saber: direito natural e direito positivo; direito objetivo e direito subjetivo; direito processual e direito material e etc.

Para os fins desta pesquisa, ou seja, para a investigação do processo de desenvolvimento da teoria do princípio da supremacia do interesse público sobre o particular pela doutrina administrativista brasileira, é especialmente interessante a análise da dicotomia direito público e direito privado, que será abordada no tópico a seguir.

\subsection{A grande dicotomia direito público e direito privado e o valor metodológico da exorbitância nos primeiros esboços teóricos do regime jurídico-administrativo propriamente dito}

Na dicção de Gustav RADBRUCH, “(...) a distinção entre direito público e direito privado está ancorada no próprio conceito de direito". ${ }^{70}$ A despeito de um possível exagero embutido na transcrita afirmação, não se pode questionar, contudo, que a dicotomia em apreço se apresente como a maior e mais antiga divisão encontrada na história do pensamento jurídico. ${ }^{71}$

Originária do Direito Romano, essa grande dicotomia é fundamentada por duas passagens bastante conhecidas do Corpus iuris - Institutiones, I, I, 4; e Digesto, I, I, I, 2 -

\footnotetext{
${ }^{69}$ Tercio Sampaio FERRAZ JR. Introdução ao estudo do direito: técnica, decisão, dominação. p. 132-133.

${ }^{70}$ Gustav RADBRUCH. Filosofia do direito. p. 183-184.

${ }^{71}$ Neste, sentido, Miguel REALE. Lições preliminares do direito. p. 335; e Paulo NADER. Introdução ao estudo do direito. p. 97.
} 
que utilizavam palavras idênticas para definir, respectivamente, o direito público e o direito privado, ${ }^{72}$ seguindo o critério da utilidade pública ou particular da relação; assim, a expressão publicum jus est quod ad statum rei romanae spectat indicava que o direito público dizia respeito à coisa romana, ao passo que a expressão privatum, quod ad singulorum utilitatem spectat indicava que o direito privado versava sobre o interesse de cada indivíduo. $^{73}$

Enquadrando o tema dentro da concepção dogmática, Tercio Sampaio FERRAZ JR. salienta que "[a] distinção entre direito público e privado não é apenas um critério classificatório de ordenação dos critérios de distinção dos tipos normativos", ${ }^{74}$ mas que também possibilita a sistematização, com “(...) o estabelecimento de princípios teóricos, básicos para operar as normas de um e outro grupo, ou seja, princípios diretores do trato com as normas, com suas consequências, com as instituições a que elas referem, os elementos congregados em sua estrutura". ${ }^{75}$

Lições similares a de Tercio Sampaio FERRAZ JR. são apresentadas por outros autores. Neste sentido, Geoffrey SAMUEL anota que "a classificação jurídica não se limita a dividir e categorizar áreas do direito. É um processo muito mais sutil, que alcança o coração de cada tópico" ${ }^{76}$ Norberto BOBBIO, indo um pouco além, ensina que a importância conceitual e classificatória da dicotomia público e privado “(...) revela-se no fato de que ela compreende, ou nela convergem, outras dicotomias tradicionais e recorrentes nas ciências sociais, que a completam e podem, inclusive substituí-la",77 porque a esfera do direito público e a esfera do direito privado são dominadas por duas imagens diferentes do direito. ${ }^{78}$ Desta feita, as imagens do direito público e do direito privado podem ser reproduzidas pelas noções de Estado e indivíduo, autoridade e

\footnotetext{
${ }^{72}$ Cf. Norberto BOBBIO. Estado, governo, sociedade: para uma teoria geral da política. p. 13.

${ }^{73}$ Cf. Miguel REALE. Lições preliminares do direito. p. 335. Também, nos dizeres de Reynaldo PORCHAT: "Direito público é aquele que se refere ao estado dos negócios romanos, isto é, do governo da república. Direito privado é o que trata dos interesses dos particulares. E o criterium da distinção está na utilidade, porque certas coisas são de utilidade pública, outras são de utilidade privada". in Reynaldo PORCHAT. Curso elementar de direito romano. v.I. p. 209-210.

74 Tercio Sampaio FERRAZ JR. Introdução ao estudo do direito: técnica, decisão, dominação. p. 137.

${ }^{75}$ Tercio Sampaio FERRAZ JR. Introdução ao estudo do direito: técnica, decisão, dominação. p. 137.

${ }^{76}$ Geoffrey SAMUEL. Epistemology and method in law., p. 263., apud José Guilherme GIACOMUZZI. Estado e contrato. Supremacia do interesse público "versus" igualdade: um estudo comparado sobre a exorbitância no contrato administrativo. p. 132.

${ }^{77}$ Norberto BOBBIO. Estado, governo, sociedade: para uma teoria geral da política. p. 15.

${ }^{78}$ Cf. Norberto BOBBIO. Da estrutura à função: novos estudos de teoria do direito. p. 152.
} 
liberdade, justiça distributiva e justiça comutativa, entre outras. E por fim, Jacques CHEVALLIER observa que a dicotomia público e privado "aparece como uma categoria de pensamento na imaginação das sociedades ocidentais, (...) expressada pela submissão de cada esfera a diferentes sistemas de valores e diferentes sistemas normativos". ${ }^{79}$

Esta última ideia colacionada, segundo a qual as esferas jurídicas pública e privada encontram-se submetidas a sistemas valorativos e normativos distintos, servirá de fundamento para que a doutrina administrativista brasileira possa aderir tanto à chamada teoria do sujeito quanto à chamada teoria do interesse; ambas apreciadas em conjunto no pensamento de Maria Sylvia Zanella DI PIETRO:

"De forma sintética, pode-se concluir que o direito público, composto por normas prevalentemente imperativas, tem por objeto a proteção predominante do interesse coletivo e a disciplina de relações que, caracterizadas pela verticalidade, têm por sujeito as pessoas jurídicas públicas ou as pessoas físicas ou jurídicas de direito privado que agem em seu nome, numa posição de supremacia sobre as demais pessoas, em decorrência da parcela de poder público de que estão investidas. $\mathrm{O}$ direito privado, ao contrário, composto por normas prevalentemente facultativas, tem por objeto a proteção predominante do interesse individual e as relações que regula, caracterizadas pela horizontalidade, têm por sujeito pessoas físicas ou jurídicas, públicas ou privadas, em situação de igualdade". ${ }^{80}$

Destarte, baseando-se nos critérios divisórios acima observados é que o direito administrativo - dentro, obviamente, da esfera do direito público - começará a ser teórica e metodologicamente construído a partir do seu regime jurídico próprio, exorbitante e derrogatório do direito comum - este, obviamente, circunscrito pela esfera do direito privado -; daí decorrendo o ensinamento de José CRETELLA JR.:

"O regime exorbitante de direito público, derrogatório do direito comum, apresenta conotações especiais que o tornam inconfundível, em razão do interesse público, sempre presente, o que torna

\footnotetext{
79 Jacques CHEVALLIER. Presentation., in Jacques CHEVALLIER (org.). Public/Privé. p. 6-7., apud José Guilherme GIACOMUZZI. Estado e contrato. Supremacia do interesse público "versus" igualdade: um estudo comparado sobre a exorbitância no contrato administrativo. p. 116.

${ }^{80}$ Maria Sylvia Zanella DI PIETRO. Do direito privado na administração pública. p. 27.
} 
privilegiada a pessoa pública ao tomar iniciativas, ocasionadas por sua posição na relação jurídico-administrativa". ${ }^{81}$

Seguido por outras manifestações doutrinárias que também poderiam ser citadas; dentre elas, porquanto bastante didática, a seguinte explanação de João Antunes dos SANTOS NETO:

"O regime jurídico administrativo propriamente dito é, pois, derrogatório e exorbitante do direito comum. Derrogatório porque rejeita em bloco as regras do direito privado que se baseiam em princípios que não se adaptam à realidade descrita e que confere à Administração Pública prerrogativas de autoridade sem paralelo nas relações entre particulares - por exemplo, no direito civil vigem postulados que tornariam inexequíveis o exercício da função de governar o interesse comum, tais como o pressuposto fundamental da igualdade das partes na relação jurídica ou mesmo o princípio da autonomia de vontade (perder-se-ia a autoridade necessária para, por exemplo, desapropriar por utilidade ou necessidade pública, fazendose necessário que o Estado-Administração se submetesse às regras ordinárias da venda e compra, caso o particular desejasse vender o bem afetado pelo interesse coletivo); exorbitante porque o direito administrativo, vai ex orbita, vai além das fronteiras estabelecidas pelas regras do direito comum, vez que é informado por princípios publicísticos próprios e diferentes daqueles que comandam os ramos ordinários do direito, em especial o direito privado (civil e comercial)". 82

Ao analisar este panorama, José Guilherme GIACOMUZZI avalia a derrogação do direito público em relação ao direito privado, condicionando este fenômeno à temática da exorbitância, ${ }^{83}$ representada pela noção de desigualdade entre Estado e indivíduo, ${ }^{84}$ não apenas no sentido de “(...) lugar-comum no discurso jurídico, mas também [como] um

\footnotetext{
${ }^{81}$ José CRETELLA JR.. Filosofia do direito administrativo. p. 201.

82 João Antunes dos SANTOS NETO. O impacto dos direitos humanos fundamentais no direito administrativo. p. 206-207.

83 Cf. José Guilherme GIACOMUZZI. Estado e contrato. Supremacia do interesse público "versus" igualdade: um estudo comparado sobre a exorbitância no contrato administrativo. p. 81.

${ }^{84} \mathrm{Ou}$ pela dicotomia de Oswaldo Aranha BANDEIRA de MELLO, poderia se falar da desigualdade entre "Estado-poder" e "Estado-sociedade". Cf. Oswaldo Aranha BANDEIRA de MELLO. Princípios gerais de direito administraivo. v.1. p. 24-27.
} 
ponto de partida metodológico" 85 do direito administrativo. A expressão "ponto de partida metodológico" deve ser entendida, neste contexto, como premissa inicial de um estudo dirigido tal qual preconizado por Geraldo ATALIBA, de igual forma, na seara do direito tributário, ou seja, “(...) sob critérios unitários de alta utilidade científica e conveniência pedagógica, em tentativa de reconhecimento coerente e harmônico da composição de diversos elementos em um todo unitário, integrado em uma realidade maior" ${ }^{86}$

Na síntese do todo o até aqui discorrido, compreende-se o valor metodológico da exorbitância enquanto fundamento de prerrogativas que existem em favor do Estado e ao mesmo tempo inexistem nas relações entre particulares, ${ }^{87}$ bem como para a construção de princípios próprios e diferentes dos que são manejados pela teoria do direito privado, ${ }^{88}$ por parte da doutrina, permitindo que o direito administrativo seja, uma vez que estudado "sob critérios unitários de alta utilidade científica e conveniência pedagógica", reconhecido como um “todo unitário", metodologicamente "integrado em uma realidade maior", isto é, a realidade do direito público.

\subsection{Um destaque paralelo: a puissance publique e sua influência na teorização do princípio da supremacia do interesse público sobre o particular}

Como visto e também de acordo com a posição de Juliana Bonacorsi de PALMA, o atributo da exorbitância se afirma no direito administrativo, inserido no contexto de busca pela autonomia científica ${ }^{89}$ que tanto marcou os primórdios de sua teorização. ${ }^{90}$ Em

\footnotetext{
${ }^{85}$ José Guilherme GIACOMUZZI. Estado e contrato. Supremacia do interesse público "versus"igualdade: um estudo comparado sobre a exorbitância no contrato administrativo. p. 78.

${ }^{86}$ Geraldo ATALIBA. Sistema constitucional tributário brasileiro. p. 4.

${ }^{87}$ Cf. Celso Antônio BANDEIRA de MELLO. Curso de direito administrativo. 28 ed. p. 44

${ }^{88}$ Neste ponto, note-se a posição de Sabino CASSESE: “[o] direito administrativo nasce do reconhecimento da inadequação do direito privado, por conseguinte, como direito derrogatório" in Sabino CASSESE. Tendeze e problema del diritto amministrativo., in Rivista Trimestrale di Diritto Pubblico, n. ${ }^{\circ}$ 4. p. 908. apud Bernardo Strobel GUIMARÃES. O exercício da função administrativa e o direito privado. p. 14.

${ }^{89}$ Sobre a autonomia científica do direito administrativo, no ensinamento de Celso Antônio BANDEIRA de MELLO: "Diz-se que há uma disciplina jurídica autônoma quando corresponde a um conjunto sistematizado de princípios e regras que lhe dão identidade, diferenciando-a das demais ramificações do Direito. Só se pode, portanto, falar em Direito Administrativo, no pressuposto de que existam princípios que lhe são peculiares e que guardem entre si uma relação lógica de coerência e unidade compondo um sistema ou regime: o regime jurídico-administrativo." in Celso Antônio BANDEIRA de MELLO. Curso de direito administrativo. 28 ed. p. 53.
} 
termos muito alinhados aos delineados nesta dissertação, a autora coloca: "[a]licerçada sobre a Dicotomia Direito Público - Direito Privado, a exorbitância indica a peculiaridade dos institutos, regras, princípios e finalidades do Direito Administrativo em relação ao Direito Comum, notadamente por voltar-se a realização do interesse público". ${ }^{91}$

Em outros dizeres, a exorbitância indica uma preponderância hierárquica entre as esferas do direito público e do direito privado; uma posição de superioridade da primeira em relação à segunda, motivada pelo maior grau de relevância atribuída, pelo direito, aos interesses públicos, quando em conflito com os interesses privados.

Essa foi, aliás, a essência da tese concebida no tópico anterior para demonstrar o valor metodológico da exorbitância na construção teórica do regime jurídicoadministrativo propriamente dito.

Por modo didático, a exemplo de José Guilherme GIACOMUZZI, ${ }^{92}$ Carlos Ari SUNDFELD projeta as noções de Estado e indivíduo sobre as esferas pública e privada, respectivamente, para demonstrar de que forma o direito justifica a premissa através da qual o direito público torna-se exorbitante do direito privado:

"A existência do Estado é justificada pela necessidade de atender a certos interesses coletivos, que os indivíduos isolados não podem alcançar. Esses interesses, cuja realização é atribuída ao Estado, chama-se interesses públicos, por oposição aos interesses privados, titularizados pelos particulares. O direito, como seria de esperar, qualifica os primeiros como mais relevantes que os segundos, e o faz conferindo-lhes prioridade no confronto com estes. Quando se chocam, o interesse público tem preferência sobre o privado. Isso não significa que os interesses privados não tenham proteção jurídica; certamente a têm, mas menos intensa que a dada ao interesse público". ${ }^{93}$

A posição de superioridade do Estado sobre o indivíduo justifica-se, portanto, pela necessidade de atendimento a certos interesses coletivos, impossíveis de serem atendidos

\footnotetext{
${ }^{90}$ Cf. Juliana Bonacorsi de PALMA. Atuação administrativa consensual: estudo dos acordos substitutivos no processo administrativo sancionador. p. 41.

91 Juliana Bonacorsi de PALMA. Atuação administrativa consensual: estudo dos acordos substitutivos no processo administrativo sancionador. p. 41.

92 Consultar, neste mesmo capítulo, o tópico 2.2. retro.

${ }^{93}$ Carlos Ari SUNDFELD. Fundamentos de direito público. p. 154.
} 
sem a atuação estatal. Não se mostra por outra razão a observação de Diego Zegarra VALDIVIA, no sentido de que o poder público, nele compreendido o poder dos governantes, está justificado pela demanda de satisfação das necessidades coletivas das pessoas. $^{94}$ Ocorre que, para que a descrita premissa tenha efetiva funcionalidade nas relações jurídicas, faz-se necessário que o Estado exerça autoridade sobre o indivíduo.

Novamente, Carlos Ari SUNDFELD ensina:

"Decorre da maior importância dos interesses públicos a autoridade de que desfruta o Estado em suas relações jurídicas com os particulares. A autoridade pública conferida ao Estado pelas normas jurídicas é a consequência, no mundo do direito, da qualificação, feita pelo constituinte ou pelo legislador, de certos interesses como mais relevantes que outros. Em outros termos: o interesse público surge como tal, para o mundo jurídico, quando as normas atribuem ao ente que dele cura poderes de autoridade". ${ }^{95}$

$(\ldots)$

"Porque o Estado exerce a autoridade pública, diz-se, metaforicamente, que as relações jurídicas entre ele e os particulares são verticais, ocupando aquele o polo mais elevado, e este o polo inferior. Nisso difere o direito público do direito privado. Entre particulares, os interesses são da mesma estatura e, em consequência, protegidos de modo equivalente. Daí as relações privadas serem horizontais, sem que uma das partes exerça autoridade sobre a outra". ${ }^{96}$

Neste ponto, considera-se a autoridade pública como um poder de comando modulado por parâmetros de juridicidade - reconhecidos pelas normas legais e principiológicas estabelecidas por determinada ordem jurídica, de acordo com a sua constituição vigente - e exercido de forma proporcional à necessidade de sua imposição para o atendimento do interesse público.

Tal concepção, a da existência de poderes de autoridade detidos pelo Estado e exercitáveis em face dos particulares, provém, em grande medida, da chamada Escola da

\footnotetext{
${ }^{94}$ Cf. Diego Zegarra VALDIVIA. El servicio público: fundamentos. p. 91.

${ }^{95}$ Carlos Ari SUNDFELD. Fundamentos de direito público. p. 155.

${ }^{96}$ Carlos Ari SUNDFELD. Fundamentos de direito público. p. 155.
} 
Puissance Publique ${ }^{97}$ e evidencia a sua influência - ainda que em eterna dialética com a não menos importante Escola do Serviço Público ${ }^{98}$ - no desenvolvimento teórico do direito administrativo, ${ }^{99}$ sobretudo, a partir da sistematização proposta por Maurice HAURIOU.

Maurice HAURIOU é considerado o sistematizador da Puissance Publique, escola de pensamento desenvolvida na França - "École de La Puissance Publique", também denominada Escola de Toulouse e anteriormente defendida por Louis-Edouard Julien LAFERRIÈRE e León AUCOC ${ }^{100}$ - no final do século XIX. ${ }^{101}$

Pela noção de puissance publique, que, como dito, dá nome à escola, a teoria elaborada por Maurice HAURIOU caracteriza o regime jurídico-administrativo como resultado da "centralização administrativa" de todo o poder estatal, com especial atenção para a centralização do poder de coação ${ }^{102}$ - bem como do monopólio da força que lhe é inato - assim compreendido como meio a ser empregado para a tutela e a satisfação do interesse geral; ${ }^{103}$ o interesse geral, por sua vez, encontra-se titularizado pelo Estado e desvencilhado do interesse privado, constituindo o fundamento legitimador do poder de coação administrativamente centralizado, ou seja, da puissance publique propriamente dita. $^{104}$

Por essa teoria, ainda, de acordo com a análise de Bernardo Strobel GUIMARÃES, “(...) a essência do Direito Administrativo residiria na capacidade que se reconhece à Administração de impor sua vontade sobre os particulares, de modo a garantir

\footnotetext{
97 Luís Filipe Colaço ANTUNES opina: "No direito administrativo, a idéia de puissance publique constitui a representação através da qual são sistematizadas as prerrogativas e os poderes de autoridade de que a Administração pública possui para prosseguir o interesse público." in Luís Filipe Colaço ANTUNES. $O$ direito administrativo sem estado - crise ou fim de um paradigma? p. 31.

98 Conhecida também como Escola de Bordeaux e inaugurada por León DUGUIT - Cf. Daniel Wunder HACHEM. Princípio constitucional da supremacia do interesse público. p. 51-52 -. Sobre isso, ver também Marçal JUSTEN FILHO, para quem “(...) a fundamentação filosófica do direito administrativo ainda se reporta à clássica disputa entre Duguit e Hauriou, nos primeiros decênios do século XX (...)”. in Marçal JUSTEN FILHO. $O$ direito administrativo de espetáculo. in Alexandre Santos de ARAGÃO; Floriano Peixoto de Azevedo MARQUES NETO (coord.). Direito administrativo e seus novos paradigmas. p. 67.

${ }^{99}$ Cf. Celso Antônio BANDEIRA de MELLO. Curso de direito administrativo. 28 ed. p. 44-52.

${ }^{100}$ Cf. Odete MEDAUAR. O direito administrativo em evolução. p. 37.

${ }^{101}$ Cf. Juliana Bonacorsi de PALMA. Atuação administrativa consensual: estudo dos acordos substitutivos no processo administrativo sancionador. p. 41.; e Daniel Wunder HACHEM. Princípio constitucional da supremacia do interesse público. p. 51.

${ }^{102}$ Cf. Maurice HAURIOU. Précis de droit administratif et e droit public géneral. p. 133.

${ }^{103}$ Cf. Maurice HAURIOU. Précis de droit administratif et e droit public géneral. p. 3.

${ }^{104}$ Cf. Juliana Bonacorsi de PALMA. Atuação administrativa consensual: estudo dos acordos substitutivos no processo administrativo sancionador. p. 38.
} 
a satisfação de interesses coletivos por ela tutelados". ${ }^{105}$ Para o autor, “(...) [d]aí que em suas relações, a Administração conta com vias favorecidas que traduzem a ideia de supremacia que lhe seria inerente". ${ }^{106}$

Ao que se nota, e no mesmo sentido observa Daniel Wunder HACHEM, dentro da sistematização teórica de Maurice HAURIOU, o direito administrativo passa a ser explicado por meio de uma racionalidade que gira em torno da noção de puissance publique. Esta racionalidade terá como base os poderes especiais ostentados pelo Estado, isto é, prerrogativas exorbitantes cujo manejo se justificaria por conta da posição de superioridade da Administração Pública frente aos administrados, ${ }^{107}$ traduzindo uma suposta ideia matriz do Direito Administrativo, segundo a qual, nessa teoria, a autoridade pública se torna não somente um meio de ação para a tutela e satisfação do interesse público, mas, sim, a garantia de que pela sua imposição, referido interesse será efetivamente tutelado e satisfeito.

Mais que isso; se é assim, então, impõe-se reconhecer, de forma até bastante significativa, a influência da teoria de Maurice HAURIOU na construção doutrinária do princípio da supremacia do interesse público sobre o particular, pois, como salienta Juliana Bonacorsi de PALMA, “(...) tanto a origem da puissance publique quanto os exercícios dos direitos dessa natureza pela Administração condicionam-se à satisfação do interesse geral", ${ }^{108}$ sendo que, "[s]e a presença da puissance publique marca a verticalidade das relações administrativas e aquela, por sua vez, funda-se no interesse geral, a supremacia da Administração consiste na supremacia do interesse geral, cuja tutela é dever do ente administrativo". 109

\subsection{Uma ressalva: a doutrina administrativista brasileira influenciada por referenciais teóricos anteriores à puissance publique}

\footnotetext{
${ }^{105}$ Bernardo Strobel GUIMARÃES. O exercício da função administrativa e o direito privado. p. 30.

${ }^{106}$ Bernardo Strobel GUIMARÃES. O exercício da função administrativa e o direito privado. p. 30.

${ }^{107}$ Cf. Daniel Wunder HACHEM. Princípio constitucional da supremacia do interesse público. p. 51.

108 Juliana Bonacorsi de PALMA. Atuação administrativa consensual: estudo dos acordos substitutivos no processo administrativo sancionador. p. 36.

109 Juliana Bonacorsi de PALMA. Atuação administrativa consensual: estudo dos acordos substitutivos no processo administrativo sancionador. p. 36.
} 
Em face do que se concluiu ao final do tópico anterior, não seria descabido indagar, pois, se da linha de pensamento sistematizada por Maurice HAURIOU, a doutrina administrativista brasileira tenha coletado, realmente, as primeiras "sementes" do princípio da supremacia o interesse público sobre o particular e plantado no "jardim" de seu plano teórico.

Embora seja inegável a relevância da fundamentação contida na teoria da puissance publique, não convém simplificar a riqueza de fatores que conduziram o direito administrativo brasileiro a ser estruturado por prerrogativas exorbitantes e instrumentais ao atendimento dos interesses públicos, resumindo este processo de desenvolvimento sistemático, única e exclusivamente, à influência de Maurice HAURIOU. ${ }^{110}$

$\mathrm{Na}$ verdade, a própria divisão entre direito público e direito privado, tal qual extraída do direito romano, pode-se dizer, facilitou a pré-conceptualização de um direito extraordinário em favor das "autoridades administrativas", exorbitante do direito comum quando, por exemplo, na Idade Média, o poder senhorial ou municipal impingia, aos membros da coletividade, sacrifícios para a satisfação do interesse geral ${ }^{111}$ - ainda que não se force um entendimento buscando a aproximação do "interesse geral" da Coroa com o “interesse geral” do Estado, pois, certamente, não é o caso. ${ }^{112}$ Por óbvio, são concepções distintas -

O poder estatal como princípio de ação para a realização do interesse público é ideia que basicamente funda, também, a teoria do direito administrativo italiano, surgida, curiosamente, antes do desenvolvimento da Escola da Puissance Publique, na França. Odete MEDAUAR, ao falar sobre Gian Domenico ROMAGNOSI - a quem se deva, possivelmente, o primeiro ensaio de exposição do direito administrativo, pela obra

${ }^{110}$ Cf. Juliana Bonacorsi de PALMA. Atuação administrativa consensual: estudo dos acordos substitutivos no processo administrativo sancionador. p. 40.

${ }^{111}$ Cf. Gregóire BIGOT. Introducion historique au droit administratif depuis 1789. p. 18. apud Bernardo Strobel GUIMARÃES. O exercício da função administrativa e o direito privado. p. 17.

112 O que também não impede, por outro lado, que se declare, tal como o fez Francisco Maria de Souza FURTADO de MENDONÇA, que "o direito administrativo sempre existiu porque o exercício de administrar é condição essencial da existência coletiva; só deve-se aos tempos modernos a classificação das leis administrativas, a separação dos princípios e a dedução de consequências em summa a theoria e o systema. Assim encontrando as leis administrativas confundidas com as civis, devemos ter em vista constantemente que as relativas ao estado e qualidade das pessoas, propriedade privada, e repressão dos delitos constituem o direito civil; e as que tem por objecto o poder público, a organização, deveres e atribuições do governo em negócios de interesse público, o direito administrativo". in Francisco Maria de Souza FURTADO de MENDONÇA. Excerpto de direito administrativo pátrio. p. 22. apud Maria Sylvia Zanella DI PIETRO. 500 anos de direito administrativo brasileiro. in Revista Diálogo Jurídico. $\mathrm{n}^{\circ} .10$, p. 8. 
"Principi fondamentali di diritto amministrativo", publicada em $1814^{113}$-, lembra que "[s]ua ideia de Estado é típica do absolutismo iluminado: poder autônomo em relação à coletividade, que se autolegitima na sua objetiva capacidade de satisfazer necessidades sociais". 114

De forma semelhante pode-se examinar o processo evolutivo do direito administrativo alemão que, segundo comenta Ernst FORSTHOFF, tem sua sistematização sensivelmente influenciada pela dicotomia Estado e sociedade - nela compreendida o valor metodológico da exorbitância como fundamento de prerrogativas que existem em favor daquele sobre esta -, proposta por Robert Von MOHL, em $1829,{ }^{115}$ isto é, também em momento anterior ao desenvolvimento, na França, da Escola da Puissance Publique.

Os exemplos italiano e alemão ajudam a explicar a diversidade de referências teóricas que influenciaram a construção doutrinária do direito administrativo brasileiro, mesmo antes da teoria da puissance publique ser aqui difundida.

Por esta linha de análise, verifica-se que não por acaso, na introdução de seu livro “Direito administrativo brasileiro", publicado em 1859, Prudencio Giraldes Tavares da VEIGA CABRAL, nitidamente inspirado pelas primeiras luzes do pensamento administrativista francês, já afirmava conhecer os estudos de tantos autores pioneiros, como Louis-Marie de CORMENIN LAHAYE, Louis-Antoine MACAREL, Baron de GERANDO, Pierre-Joseph PROUDHON, Gabriel DUFOUR, Luis-Firmin Julien LAFERRIÈRE, Poul Louis Ernest PRADIER-FODERÉ e etc. ${ }^{116}$

Com efeito, no que tange, especificamente, ao processo de teorização da supremacia do interesse público sobre o particular, uma investigação histórica sobre a construção deste princípio revelará que, à luz de tantas referências provindas do direito continental europeu, a importância funcional ou instrumental da autoridade pública para a tutela e satisfação do interesse coletivo tem sido reconhecida pelo pensamento

\footnotetext{
${ }^{113}$ Cf. Oswaldo Aranha BANDEIRA de MELLO. Princípios gerais de direito administraivo. v.1. p. 62.; e Odete MEDAUAR. $O$ direito administrativo em evolução. p. 29.

${ }^{114}$ Odete MEDAUAR. O direito administrativo em evolução. p. 68.

${ }^{115}$ Cf. Ernst FORSTHOFF. Traité de droit administratif allemand. p. 94-95.

${ }^{116}$ Prudencio Giraldes Tavares da VEIGA CABRAL. Direito administrativo brasileiro. Rio de Janeiro: Typographia Universal de Laemert. 1859. Cf. Odete MEDAUAR. O direito administrativo em evolução. p. 61.
} 
administrativista brasileiro desde a época do Império; período que corresponde à publicação dos seus primeiros ensaios doutrinários.

\subsection{Os primeiros registros doutrinários do princípio da supremacia do interesse público sobre o particular no direito administrativo brasileiro}

Conforme o entendimento de Eunice Ferreira NEQUETE, afirma-se que a doutrina administrativista brasileira começa a se desenvolver sob influência das obras escritas pela primeira geração de publicistas franceses após a Revolução Francesa de $1789,{ }^{117}$ porém, aderindo da Itália, de acordo com a advertência de Maria Sylvia Zanella DI PIETRO, “(...) o próprio método de elaboração e estudo do direito administrativo, mais técnico-científico do que o método pragmático do direito francês". 118

O escopo deste tópico é demonstrar a evolução das concepções de verticalidade nas relações entre Estado e indivíduo que, através dos tempos, ajudaram a consolidar o princípio da supremacia do interesse público sobre o particular dentro do sistema teórico construído pela doutrina administrativista brasileira. Neste quadro, a reprodução de passagens doutrinárias desenvolvidas, desde a época imperial, por alguns autores - ainda que de forma esparsa, é verdade -, acabam por resgatar uma série de posicionamentos no sentido de que o Estado possui o dever de, no exercício de suas potestades, realizar o interesse coletivo, fazendo-o prevalecer sobre os interesses privados. ${ }^{119}$

Assim, em 1857 é publicada a obra "Direito publico brazileiro e analyse da constituição do Império", ${ }^{120}$ de autoria de José Antônio PIMENTA BUENO que, de início, já observa que as relações dos homens necessitam ser bem divididas e fixadas pelo critério do interesse geral, coletivo ou comum e do interesse particular ou individual, "[s]endo facil de prever, como de facto foi, desde o berço da civilisação, que esses dous interesses podião

\footnotetext{
${ }^{117}$ Cf. Eunice Ferreira NEQUETE. Fundamentos históricos do princípio da supremacia do interesse público. p. 106.

${ }^{118}$ Maria Sylvia Zanella DI PIETRO. O direito administrativo brasileiro sob influência dos sistemas de base romanística e da Common Law. in Revista Eletrônica de Direito Administrativo Econômico. no. 8, p. 7.

119 Neste sentido, também, ver Daniel Wunder HACHEM. Princípio constitucional da supremacia do interesse público. p. 42.

${ }^{120}$ José Antônio PIMENTA BUENO. Direito publico brazileiro e analyse da constituição do Império. Rio de Janeiro: Typographia Imp. E Const. de J. Villeneuve e C. 1857.
} 
mais de uma vez achar-se em conflicto com grave prejuizo reciproco". ${ }^{21}$ Neste caso, segundo o autor:

“(...) [A] razão e a sciencia de todos os paizes civilisados procurarão distinguir e separar as relações, em que o interesse individual poderia contrariar directa ou indirectamente o interesse publico, e em que por isso mesmo deveria ceder passo a este, e aquellas em que por não affectá-lo, ou sòmente affectar mediata ou secundariamente, deveria ser independente, livre, entregue e inteligencia e vontade do individuo". ${ }^{122}$

"O Direito Público, Jus Publicum, quod ad statum reipublicae spectat, tem por domínio todas as relações do cidadão para com o Estado, relações do interesse geral, e que por isso mesmo não pertencem á ordem privada. Elle organisa as condições do bem ser commum; seu norte é o salus publica suprema Lex; attende e protege especialmente o interesse collectivo, bene esse civitatis, e por amor delle despreza o interesse individual nos casos em que lhe é subordinado, pois que fora desses casos deve respeita-lo como um direito reconhecido e independente." 123

Prosseguindo, na obra "Ensaio sobre o direito administrativo", ${ }^{124}$ publicada em 1862, Paulino José Soares de Souza, o Visconde do URUGUAY sustenta que o direito administrativo “(...) occupa-se do interesse geral, (...) tomando medidas de policia administrativa e preventiva, que tendão a assegurar aos cidadãos os benefícios da ordem, segurança e salubridade publica (...)"; ${ }^{125}$ posicionamento similar ao de Antonio Joaquim RIBAS, asseverando em 1866, com o livro "Direito administrativo brasileiro: noções preliminares", ${ }^{126}$ que “(...) o Direito Administrativo determina a natureza das relações que ligão a autoridade civil á força publica (...)""127 e "[a]utoriza a administração, com um fim

\footnotetext{
${ }^{121}$ José Antônio PIMENTA BUENO. Direito publico brazileiro e analyse da constituição do Império. p. 8.

${ }^{122}$ José Antônio PIMENTA BUENO. Direito publico brazileiro e analyse da constituição do Império. p. 8.

${ }^{123}$ José Antônio PIMENTA BUENO. Direito publico brazileiro e analyse da constituição do Império. p. 8.

${ }^{124}$ Paulino José Soares de Souza, Visconde do URUGUAY. Ensaio sobre o direito administrativo. Rio de Janeiro: Nacional. 1862.

${ }^{125}$ Paulino José Soares de Souza, Visconde do URUGUAY. Ensaio sobre o direito administrativo. p. 10.

${ }^{126}$ Antonio Joaquim RIBAS. Ensaio sobre o direito administrativo. Rio de Janeiro: F. L. Pinto \& C. 1866.

${ }^{127}$ Antonio Joaquim RIBAS. Direito administrativo: noções preliminares. p. 13.
} 
de utilidade pública, a tomar certas medidas para a sustentação da ordem, salubridade, viabilidade, segurança individual, moral, pública, etc". ${ }^{128}$

Adiante, em sentido contrário, não se pode deixar de expor o viés crítico - e de certa maneira, surpreendente - de Augusto Olympio VIVEIROS de CASTRO, reproduzido por diversas passagens do seu "Tratado de sciencia da administração e direito administrativo", ${ }^{129}$ publicado em 1906:

"O publico e o privado não exprimem duas espheras juridicas, definidas e substancialmente distinctas: o individuo, a familia teem vida publica, são elementos componentes do estado político nacional, e sujeitos de relações jurídico-publicas; pelo seu lado, o Estado tem a sua vida privada, que ostensivamente se revela no Direito Administrativo mais do que qualquer outro ramo jurídico.

Tal divisão, no conceito actual, se origina no falso pressuposto de ser o direito a obra objectiva do Estado, como Governo, ao qual os indivíduos devem submetter-se". ${ }^{130}$

"A alludida distinç̧ão põe frente à frente dois termos, que não devem ser os unicos nas relações juridicas transitivas, e que tão pouco devem estar collocados em aberta opposição: taes termos são o individuo e todo o social constituído no Estado.

As relações entre o individuo e o Estado não devem ser de opposição, e sim de cooperação, sendo, além disso, impossível negar a existência de infinitos centros da vida pessoal collectiva, distincta da vida individual e da do Estado, e que são outros tantos sujeitos de possíveis relações jurídicas, nem publicas nem privadas, ou ambas as cousas conjuntamente". ${ }^{131}$

"O carater de publico, applicado em seu significado tradicional ao direito do Estado, em opposição ao direito privado dos particulares,

\footnotetext{
${ }^{128}$ Antonio Joaquim RIBAS. Direito administrativo: noções preliminares. p. 13-14.

129 Augusto Olympio VIVEIROS de CASTRO. Tratado de sciencia da administração e direito administrativo. Rio de Janeiro: Imprensa Nacional. 1906.

130 Augusto Olympio VIVEIROS de CASTRO. Tratado de sciencia da administração $e$ direito administrativo. p. 88-89.

131 Augusto Olympio VIVEIROS de CASTRO. Tratado de sciencia da administração $e$ direito administrativo. p. 89.
} 
produz uma suggestão muito perniciosa, tanto no direito político, como no administrativo.

Devido a esta suggestão, os tratadistas e os políticos conceituam o direito publico como especial, como o direito do todo, do Estado, do soberano, que requer e se reveste de fórmas, forças e meios autorictarios particularíssimos.

A natureza privilegiada que, em muitos paizes, teem, apesar do direito constitucional, a relação jurídico-publica, os actos da autoridade, os actos administrativos de mando, as manifestações potentes do Poder Publico, como Parlamento, como Executivo, ou como Administração publica, provém, sem duvida, do influxo dessa suggestão". ${ }^{132}$

De seu turno, em 1914, com a publicação da obra "Direito administrativo brasileiro: exposição summaria e abreviada", ${ }^{133}$ Alcides CRUZ apresenta suas linhas de pensamento acerca deste tema, com a análise do instituto da expropriação:

"A expropriação, quer por utilidade publica, quer por necessidade publica, é um acto unilateral pelo qual o Estado obriga o proprietário particular a ceder a sua propriedade em proveito de algum empreendimento publico, mediante justa indemnisação.

\section{(...)}

Pretendiam as antigas teorias que o direito de expropriação derivava de um poder especial e direto, que o Estado gozaria sobre todas as cousas pertencentes à propriedade privada, consubstanciando na famosa figura do dominio eminente.

Outro, porém, é o fundamento do direito de expropriação reconhecido modernamente. O Estado no desempenho da sua missão de assegurar o mantenimento do conjunto dos direitos da coletividade, vê-se obrigado a impor limitações não só à liberdade do indivíduo, como tambem á sua propriedade, isto é, ao próprio direito privado do subdito. Portanto esse direito do Estado, é um verdadeiro direito público e uma manifestação do direito de soberania geral". ${ }^{134}$

132 Augusto Olympio VIVEIROS de CASTRO. Tratado de sciencia da administração e direito administrativo. p. 90.

${ }^{133}$ Alcides CRUZ. Direito administrativo brasileiro: exposição summaria e abreviada. Paris: Aillaud, Alves \& Cia. 1914.

${ }^{134}$ Alcides CRUZ. Direito administrativo brasileiro: exposição summaria e abreviada. p. 215. 
Na sequência, em 1919, publicando o livro "Direito administrativo e sciencia da administração", ${ }^{135}$ Eurico de OLIVEIRA SANTOS trata do assunto com os seguintes dizeres:

"Penso que, por força das transformações sucessivas por que teem passado povos e governos, todos acabaram por se convencer da necessidade de se harmonizarem direitos e interesses oppostos, a bem não só de altas conveniências, que entendem com a propria conservação dos Estados, como das garantias de bem estar, devidas a cada um dos governados, considerado sob o ponto de vista dos seus direitos individuaes.

Isto explica o facto de, em todos os paizes constitucionaes, o interesse particular ceder ao interesse geral; o interesse do individuo ceder deante do interesse publico, e o interesse do departamento ou da communa ceder deante do direito do Estado". ${ }^{136}$

E pela mesma esteira, outros posicionamentos convergentes são elencados, como o de Aarão REIS, ao publicar o seu "Direito administrativo brazileiro", ${ }^{137}$ em 1923, salientando que, com frequência, o direito administrativo impõe “(...) aos mais respeitáveis interêsses privados indivíduais - em benefício do interêsse público coletívo - ônus bem pezados e sacrifícios, mesmo, dos mais penozos (...)"; ${ }^{38}$ seguido por Themístocles Brandão CAVALCANTI, com a publicação, em 1936 da obra "Instituições de direito administrativo", ${ }^{139}$ afirmando que o Estado tem como finalidade “(...) zelar, não só pelo interesse individual, mas principalmente pelos interesses collectivos, que se sobrepõem a todos os demais", ${ }^{140}$ por Tito Prates da FONSECA, ressaltando, em seu livro "Lições de direito administrativo", ${ }^{141}$ publicado em 1943, que "[a] precedência do interêsse público sôbre o privado é princípio verdadeiro; mal trabalhado, no entanto, pode conduzir à lesão

\footnotetext{
${ }^{135}$ Eurico de OLIVEIRA SANTOS. Direito administrativo e sciencia da administração. Rio de Janeiro: Jacintho Ribeiro dos Santos. 1919.

${ }^{136}$ Eurico de OLIVEIRA SANTOS. Direito administrativo e sciencia da administração. p. 259.

137 Aarão REIS. Direito administrativo brazileiro. Rio de Janeiro: Officinas Graphicas Villas Boas \& C. 1923.

${ }^{138}$ Aarão REIS. Direito administrativo brazileiro. p.32.

139 Themístocles Brandão CAVALCANTI. Instituições de direito administrativo. Rio de Janeiro: Freitas Bastos. 1936.

${ }^{140}$ Themístocles Brandão CAVALCANTI. Instituições de direito administrativo. p. 204.

141 Tito Prates da FONSECA. Lições de direito administrativo. Rio de Janeiro: Freitas Bastos. 1943.
} 
de direitos individuais ou a contorsão de direitos da Administração pública"; ${ }^{142}$ e também por José Horácio MEIRELLES TEIXEIRA, registrando, com a publicação do livro “Estudos de direito administrativo. v.1.”, ${ }^{143}$ em 1949, que “(...) [r]elativamente ao direito de construir, manifesta-se o interêsse público através de limitações, restrições e exigências em benefício da coletividade, geralmente relativas à segurança, higiene e estética das edificações" $" 144$ e que "[o] interêsse público, a paz social, o bem estar e a segurança da coletividade justificam plenamente tais restrições, desde que a lei, ou o regulamento, não contravenham disposição legal superior". ${ }^{145}$

Em 1952, chama atenção a publicação do artigo "O poder de polícia e seus limites", ${ }^{146}$ de Caio TÁCITO, pela reunião de ideias expostas, condensadas através do conceito de que o poder de polícia consiste no “(...) conjunto de atribuições concedidas à administração para disciplinar e restringir, em favor do interesse público adequado, direitos e liberdades individuais" "147 eis que "(...) é da própria essência constitucional das garantias do indivíduo a supremacia dos interêsses da coletividade." ${ }^{\prime 48}$ Destarte, em 1956, Fernando Henrique MENDES de ALMEIDA publica a obra "Noções de direito administrativo"149 e discorre sobre potenciais conflitos entre interesse público e interesse particular, em hipótese, assim, definindo: “[o] essencial é que, além de êle [o interesse particular] ser protegido por ação, quando em face do interesse coletivo, a êste se subordine e com êste não colida, pois, caso contrário, se lhe debilita a proteção, prevalecendo o interêsse coletivo". 150

Naturalmente, é de se notar que por uma linha de sucessivas construções doutrinárias, as então pré-existentes concepções de verticalidade das relações administrativas vão, paulatinamente, ganhando embasamento teórico para dar à supremacia

\footnotetext{
${ }^{142}$ Tito Prates da FONSECA. Lições de direito administrativo. p. 328.

143 José Horácio MEIRELLES TEIXEIRA. Estudos de direito administrativo. v.1. São Paulo: Departamento Jurídico da Prefeitura Municipal de São Paulo. 1949.

${ }^{144}$ José Horácio MEIRELLES TEIXEIRA. Estudos de direito administrativo. v.1. p. 266.

${ }^{145}$ José Horácio MEIRELLES TEIXEIRA. Estudos de direito administrativo. v. 1. p. 271.

${ }^{146}$ Caio TÁCITO. O poder de polícia e seus limites. in Revista de Direito Administrativo , n. ${ }^{\circ}$ 27. p. 1-11.

${ }^{147}$ Caio TÁCITO. O poder de polícia e seus limites. in Revista de Direito Administrativo, n. ${ }^{\circ} 27$. p. 8.

${ }^{148}$ Caio TÁCITO. O poder de polícia e seus limites. in Revista de Direito Administrativo, n. ${ }^{\circ} 27$. p. 8.

${ }^{149}$ Fernando Henrique MENDES de ALMEIDA. Noções de direito administrativo. São Paulo: Saraiva. 1956.

${ }^{150}$ Fernando Henrique MENDES de ALMEIDA. Noções de direito administrativo. p. 81.
} 
do interesse público sobre o particular uma feição principiológica e consequentemente dogmática no direito administrativo brasileiro.

Por esta trilha, ainda, oportuno destacar a obra "Direito administrativo", 151 de Onofre MENDES JR., publicada em 1961. Nela, o autor defende a "predominância do poder do Estado sobre o indivíduo" e a "superioridade do interesse público em relação ao interesse individual" como meios de alcance do seu fim social, consubstanciada pela realização do bem comum:

\begin{abstract}
"A predominância do Poder do Estado sobre o do indivíduo explicase, precisamente porque o poder público é poder social, instituído em pról da realização do fim social, por intermédio do Estado. Os indivíduos são meios de que se serve o Estado para a realização do fim social que lhe compete. Daí, a autoridade para constrangê-los a praticar tudo quanto vise à realização do fim social, que, sinteticamente, se resume no bem comum.

A superioridade do interêsse público em relação ao interesse individual se explica por diversos motivos, bastando, entretanto, para pô-la em evidência a consideração a brevidade da vida do indivíduo em relação à sociedade civil, que o encarna. Daí, a afirmação de STO. TOMÁS DE AQUINO, segundo o qual "o bem do indivíduo não constitui o fim último do Estado, mas sim o bem comum". E é para a consecução do bem comum que o Estado pode lançar mão de todos os meios que sejam necessários, manifestando-se aí o seu poder sobre o indivíduo".

Mas, precisamente porque essa atuação do Estado deve orientar-se no sentido de alcançar o seu fim social, que é a realização do bem comum, não o de cada indivíduo, isoladamente considerado, senão o de todos e o de cada um, é que se fixa um limite ao seu poder, que será legítimo e obrigará a todos, enquanto se conservar na esfera da impulsão dos meios indispensáveis à consecução daquele fim". ${ }^{152}$
\end{abstract}

Sem embargo, a realização do "bem comum" passa a ser expressamente traduzida pela consecução do fim estatal, também, no legado deixado por Oswaldo Aranha

\footnotetext{
${ }^{151}$ Onofre MENDES JR.. Direito administrativo. Belo Horizonte: Bernardo Álvares S.A. 1961.

${ }^{152}$ Onofre MENDES JR.. Direito administrativo. p. 68.
} 
BANDEIRA de MELLO. A este propósito, pois, pinçam-se de seu artigo "Conceito de direito administrativo", ${ }^{153}$ publicado no ano de 1964, os seguintes comentários:

"A manifestação da vontade do Estado, internamente, se faz, de regra, de forma unilateral, tendo em vista o interesse estatal, como expressão do interêsse do todo social, em contraposição à outra pessoa por ela atingida ou com ela relacionada. E, mesmo quando as situações jurídicas se formam acaso por acordo entre partes de posição hierárquica diferente, isto é, entre o Estado e outras entidades administrativas menores e os particulares, o regime jurídico a que se sujeitam é de caráter estatutário. Portanto, a autonomia da vontade só existe na formação do ato jurídico. Porém, os direitos e deveres relativos à situação jurídica dela resultante, a sua natureza e extensão são regulamentados por ato unilateral do Estado, jamais por disposições criadas pelas partes. Ocorrem, através, de processos técnicos de imposição autoritária da sua vontade, nas quais se estabelecem as normas adequadas e se conferem os poderes próprios para atingir o fim estatal que é a realização do bem comum. É a ordem natural do direito interno, nas relações com outras entidades menores ou com os particulares". ${ }^{154}$

E por fim, sem a pretensão de exaurimento da vasta bibliografia historicamente produzida pela doutrina administrativista brasileira, cabe deter o olhar sobre a primeira edição da obra "Direito administrativo brasileiro", ${ }^{155}$ de Hely Lopes MEIRELLES, também publicada em 1964, atendo-se ao tirocínio entabulado ao longo das páginas que o autor dedicou ao tema para afirmar a "supremacia do Poder Público sobre os cidadãos" como princípio jurídico próprio da esfera pública, contraposto ao princípio da igualdade das partes, inerente à esfera privada:

"Com efeito, enquanto o Direito Privado repousa sôbre a igualdade das partes na relação jurídica, o Direito Público assenta em princípio inverso, qual seja o da supremacia do Poder Público sôbre os cidadãos, dada a prevalência dos interesses coletivos sôbre os

\footnotetext{
153 Oswaldo Aranha BANDEIRA de MELLO. Conceito de direito administrativo. in Revista da Universidade Católica de São Paulo, vol. XXVII. apud Celso Antônio BANDEIRA de MELLO. O conteúdo do regime jurídico-administrativo e seu valor metodológico. in Revista de Direito Público, $\mathrm{n} .^{\circ} 2$. $\mathrm{p}$. 44-61.

154 Oswaldo Aranha BANDEIRA de MELLO. Conceito de direito administrativo. in Revista da Universidade Católica de São Paulo, vol. XXVII. p. 36. apud Celso Antônio BANDEIRA de MELLO. O conteúdo do regime jurídico-administrativo e seu valor metodológico. in Revista de Direito Público, n. ${ }^{\circ} 2$. p. 44-61.

${ }^{155}$ Hely Lopes MEIRELLES. Direito administrativo brasileiro. São Paulo: Revista dos Tribunais. 1964.
} 
individuais. Dessa desigualdade originária entre a Administração e os particulares, resultam inegáveis privilégios e prerrogativas para o Poder Público, privilégios e prerrogativas que não podem ser desconhecidos nem desconsiderados pelo intérprete ou aplicador das regras e princípios desse ramo do Direito. Sempre que entrarem em conflito o direito do indivíduo e o interesse da comunidade, há de prevalecer este, uma vez que o objetivo primacial da Administração é o bem-comum. As leis administrativas visam, geralmente, a assegurar essa supremacia do Poder Público sôbre os indivíduos, enquanto necessária à consecução dos fins da Administração. Ao aplicador da lei compete interpretá-la de modo a estabelecer o equilíbrio entre os privilégios estatais e os direitos individuais, sem perder de vista aquela supremacia". ${ }^{156}$

Da observação de todas as referências sequencialmente arroladas, vislumbram-se os primeiros registros doutrinários do princípio da supremacia do interesse público sobre o particular no direito administrativo brasileiro. Como se vê, trata-se, basicamente, de considerações pontuais e didáticas, utilizadas tanto num plano geral, para distinguir as figuras do Estado e do indivíduo, quanto para manejar noções mais específicas, notadamente, as de "expropriação" e "poder de polícia".

Nada obstante, com o passar dos anos, o próprio aumento de complexidade das relações administrativas fará com que os doutrinadores comecem a buscar o aperfeiçoamento do ferramental teórico até então - neste processo evolutivo desenvolvido. Em outras palavras, isto significa que o problema da sistematização do direito administrativo, através de um conjunto principiológico próprio, terá sua importância repercutida de forma cada vez mais intensa.

Dentro deste contexto, estudos específicos passarão a investigar o princípio da supremacia do interesse público sobre o particular, com mais foco e profundidade, consoante será demonstrado no tópico seguinte.

\subsection{O princípio da supremacia do interesse público sobre o particular metodologicamente teorizado pela doutrina administrativista brasileiro}

${ }^{156}$ Hely Lopes MEIRELLES. Direito administrativo brasileiro. p. $22-23$. 
Para além de toda a saga evolutiva acima apresentada, há quem afirme que o princípio da supremacia do interesse público sobre o particular comece a ser especificamente teorizado apenas a partir do ano de 1967, com a publicação do artigo " $O$ conteúdo do regime jurídico-administrativo e seu valor metodológico", ${ }^{157} \mathrm{de}$ Celso Antônio BANDEIRA de MELLO, ${ }^{158}$ justamente pela preocupação metodológica do autor em definir o direito administrativo como um sistema coerente e lógico, orientado por princípios próprios, tendentes a lhe conferir unidade, organicidade e, consequentemente, autonomia científica.

Esse sistema coerente e lógico é, pelo próprio autor, chamado de regime jurídicoadministrativo. Para a compreensão de tal nomenclatura, Celso Antônio BANDEIRA de MELLO ensina que o termo regime jurídico designa o sistema de uma disciplina jurídica; sistema, este, composto “(...) por um conjunto de princípios que lhe dão especificidade em relação ao regime de outras disciplinas". ${ }^{159}$ No caso do direito administrativo - conforme já demonstrado no tópico 2.2. retro - o regime jurídico-administrativo presta-se a designar, portanto, o sistema que o especifica como exorbitante e derrogatório em relação às outras disciplinas jurídicas.

Na teoria elaborada por Celso Antônio BANDEIRA de MELLO, a sistemática do regime jurídico-administrativo apresenta-se, de acordo com o seu pensamento, coerente e lógica porque nela os princípios funcionam “(...) interligando-se todos, não só em plano vertical, como horizontal, formando uma unidade (...)"160 alicerçada por duas "pedras de toque", ${ }^{161}$ dois cânones jurídicos intercomplementares, que mantêm o sistema em

${ }^{157}$ Celso Antônio BANDEIRA de MELLO. O conteúdo do regime jurídico-administrativo e seu valor metodológico. in Revista de Direito Público, n. ${ }^{\circ}$ 2. p. 44-61.

${ }^{158}$ Essa é a posição de Daniel Wunder HACHEM: "Em que pese a ocorrência de pontuais menções à noção de supremacia do interesse público sobre o privado, a elaboração teórica do princípio em questão, na forma como é conhecido contemporaneamente só emerge no ano de 1967, quando Celso Antônio Bandeira de Mello publica na Revista de Direito Público o artigo intitulado "O conteúdo do regime jurídicoadministrativo e o seu valor metodológico". No estudo, o autor apontava, já na introdução, a carência de uma proposta científica ordenada e sistematizada que se debruçasse de modo detido e aprofundado à temática do regime jurídico-administrativo, explicitando os princípios e subprincípios norteadores da racionalidade do Direito Administrativo". in Daniel Wunder HACHEM. Princípio constitucional da supremacia do interesse público. p. 45-46.

${ }^{159}$ Celso Antônio BANDEIRA de MELLO. O conteúdo do regime jurídico-administrativo e seu valor metodológico. in Revista de Direito Público, n. ${ }^{\circ}$ 2. p.58.

${ }^{160}$ Celso Antônio BANDEIRA de MELLO. O conteúdo do regime jurídico-administrativo e seu valor metodológico. in Revista de Direito Público , n. ${ }^{\circ}$ 2. p.58.

${ }^{161}$ Celso Antônio BANDEIRA de MELLO. O conteúdo do regime jurídico-administrativo e seu valor metodológico. in Revista de Direito Público , n. ${ }^{\circ}$ 2. p.43. 
equilíbrio: o princípio da supremacia do interesse público sobre o particular e o princípio da indisponibilidade do interesse público. ${ }^{162}$

Assim sendo, o princípio da supremacia do interesse público sobre o particular é posto como uma das disposições fundamentais do sistema coerente e lógico que é designado pelo regime jurídico-administrativo e, neste quadrante, recebe de Celso Antônio BANDEIRA de MELLO o seguinte conceito: "[t]rata-se de verdadeiro axioma reconhecível no moderno direito público. Proclama a superioridade do interesse da coletividade, firmando a prevalência dele sôbre o do particular, como condição, até mêsmo, da sobrevivência e asseguramento dêste último". ${ }^{163}$

Inserido na sistemática ora descrita, o princípio da supremacia do interesse público sobre o particular, ao mesmo tempo em que confere posições de privilégio ${ }^{164}$ e ou de supremacia ${ }^{165}$ à Administração Pública nas relações com os particulares, tem sua intensidade contrabalanceada pelo princípio da indisponibilidade do interesse público, segundo o qual os interesses da coletividade nunca se apresentam disponíveis para o administrador, porém, estão sempre vinculados ao cumprimento de alguma finalidade

${ }^{162}$ Com dizeres destacados no original, Celso Antônio BANDEIRA de MELLO aduz: “Todo o sistema de Direito Administrativo, a nosso ver, se constrói sôbre os mencionados princípios da supremacia do interêsse público sôbre o particular e indisponibilidade do interesse público". in Celso Antônio BANDEIRA de MELLO. O conteúdo do regime jurídico-administrativo e seu valor metodológico. in Revista de Direito Público, n. ${ }^{\circ}$ 2. p.46.

163 Celso Antônio BANDEIRA de MELLO. O conteúdo do regime jurídico-administrativo e seu valor metodológico. in Revista de Direito Público , n. ${ }^{\circ}$ 2. p.47.

${ }^{164}$ Segundo Celso Antônio BANDEIRA de MELLO, “[e]sta posição privilegiada encarna os benefícios que a ordem jurídica confere a fim de assegurar conveniente proteção aos interêsses públicos, instrumentando os órgãos que os representam para um bom, fácil, expedito e resguardado desempenho de sua missão. Traduz-se em privilégios que lhes são atribuídos. Os efeitos desta posição são de diversa ordem e manifestam-se em diferentes campos. Não cabem aqui delongas a respeito. Convém, entretanto, lembrar, sem comentários e precisões maiores, alguns exemplos: a presunção de veracidade e de legitimidade dos atos administrativos; o benefício de prazos em dobro para intervenção ao longo de processo judicial; a posição de ré, fruída pela Administração, na maior parte dos feitos, transferindo-se ao particular a situação de autor com os correlatos ônus, inclusive os de prova; prazos especiais para prescrição das ações em que é parte o Poder Público, etc". in Celso Antônio BANDEIRA de MELLO. O conteúdo do regime jurídico-administrativo e seu valor metodológico. in Revista de Direito Público , n. ${ }^{\circ}$ 2. p.47.

165 Para Celso Antônio BANDEIRA de MELLO, "A posição de supremacia, extremamente importante, é muitas vezes metafòricamente expressada através da afirmação de que vigora a verticalidade nas relações entre Administração e particulares; ao contrário da horizontalidade, típica das relações entre estes últimos. Significa que o Poder Público se encontra em situação autoritária, de comando, relativamente aos particulares, como indispensável condição, para gerir os interêsses postos em confronto, a possibilidade, em favor da Administração, de constituir os privados em obrigações por meio de ato unilateral daquela. Implica, outrossim, no direito de modificar, também, unilateralmente, relações já estabelecidas”. in Celso Antônio BANDEIRA de MELLO. O conteúdo do regime jurídico-administrativo e seu valor metodológico. in Revista de Direito Público , n. ${ }^{\circ}$ 2. p.47. 
cogente. ${ }^{166}$ Daí o equilíbrio do sistema, cujo funcionamento de todos os outros princípios deriva, por lógica e coerência, da combinação entre o princípio da supremacia do interesse público sobre o particular e o princípio da indisponibilidade do interesse público. ${ }^{167}$

Esta abordagem, em que o princípio da supremacia do interesse público sobre o particular é explicado metodologicamente como parte da teoria do regime jurídicoadministrativo, será reproduzida, sem modificações, nos trabalhos futuros ${ }^{168}$ de Celso Antônio BANDEIRA de MELLO, até a promulgação da Constituição Federal de 1988. Depois e em razão disso, publicando, em 1991, uma segunda edição dos seus "Elementos de direito administrativo" ${ }^{\prime 69}$ - posteriormente, ampliada e convertida, em 1993, na obra "Curso de direito administrativo" ${ }^{170}$-, o autor trará novos apontamentos para relacionar o aludido princípio com a noção de função administrativa, realçando o viés democrático que legitima o uso das prerrogativas da Administração somente e na medida indispensável do atendimento do interesse da coletividade ${ }^{171}$; consagrando, teoricamente, as potestades públicas como “(...) "deveres poderes”, ${ }^{172}$ pois nisto se ressalta sua índole própria e se atrai atenção para o aspecto subordinado do poder em relação ao dever, sobressaindo, então, o

${ }^{166}$ Cf. Celso Antônio BANDEIRA de MELLO. O conteúdo do regime jurídico-administrativo e seu valor metodológico. in Revista de Direito Público , n. ${ }^{\circ}$ 2. p.48., apoiando-se em Ruy CIRNE LIME. Princípios de direito administrativo brasileiro. p. 53.

167 Celso Antônio BANDEIRA de MELLO enumera, embora sem pretender que sua exposição seja exauriente, dezoito princípios derivados da supremacia do interesse público sobre o particular e da indisponibilidade do interesse público: "1) Princípio da posição privilegiada dos órgãos da Administração Pública nas relações jurídicas. 2) Princípio da supremacia dos órgãos da Administração Pública (expressado sobretudo através dos seus desdobramentos contidos nos princípios imediatamente seguintes). 3) Princípio do estabelecimento unilateral de obrigações aos particulares (poder de Polícia e atos que traduzem o "império" em geral). 4) Princípio da presunção de veracidade dos atos administrativos. 5) Princípio da exigibilidade dos atos administrativos. 7) Princípio da auto-executoriedade dos atos administrativos. 8) Princípio da revocabilidade, pela Administração, dos atos administrativos. 9) Princípio da declaração de nulidade dos atos administrativos, pela Administração. 10) Princípio da modificação e resolução unilateral das relações jurídico-administrativas. 11) Princípio da legalidade. 12) Princípio da responsabilidade do Estado. 13) Princípio da obrigatoriedade do desempenho da atividade pública. 14) Princípio da discricionariedade. 15) Princípio da continuidade da atividade pública. 16) Princípio do controle administrativo. 17) Princípio da isonomia. 18) Princípio da inalienabilidade dos direitos concernentes a interesses públicos". In Celso Antônio BANDEIRA de MELLO. O conteúdo do regime jurídico-administrativo e seu valor metodológico. in Revista de Direito Público , n. ${ }^{\circ}$ 2. p.61.

${ }^{168}$ Neste ponto, ver, por exemplo, Celso Antônio BANDEIRA de MELLO. Natureza e regime jurídico das autarquias. p.292-318.

169 Celso Antônio BANDEIRA de MELLO. Elementos de direito administrativo. São Paulo: Malheiros. 1991.

${ }^{170}$ Celso Antônio BANDEIRA de MELLO. Curso de direito administrativo. 4 ed. São Paulo: Malheiros. 1993. Observação: as três primeiras edições desta obra foram publicadas como Elementos de direito administrativo. Cf. nota à $4^{a}$ edição. in Celso Antônio BANDEIRA de MELLO. Curso de direito administrativo.4 ed. São Paulo: Malheiros. 1993.

${ }^{171}$ Cf. Celso Antônio BANDEIRA de MELLO. Elementos de direito administrativo. p. 21-22.

${ }^{172}$ Cf. Celso Antônio BANDEIRA de MELLO. Elementos de direito administrativo. p. 22. 
aspecto finalístico que as informa, do que decorrerão suas inerentes limitações"173; e por último, esclarecendo a distinção entre interesses públicos ou interesses primários - “(...) que são os interesses da coletividade como um todo (...." "174 - e interesses secundários “(...) que o Estado (pelo só fato de ser sujeito de direitos) poderia ter como qualquer outra pessoa, isto é, independentemente de sua qualidade de servidor de interesses de terceiros: os da coletividade (...)", ${ }^{175}$ razão pela qual, “(...) os interesses secundários não são atendíveis senão quando coincidirem com interesses primários, únicos que podem ser perseguidos por quem axiomaticamente os encarna e representa". ${ }^{176}$

A mesma preocupação metodológica de Celso Antônio BANDEIRA de MELLO é manifestada por José CRETELLA JR., em seu artigo "Princípios informativos do direito administrativo", ${ }^{177}$ publicado em 1968. Neste ensaio, reclama-se a falta da "tratação sistemática dos princípios" ${ }^{\text {"178 }}$ que informam a disciplina em questão, já que para o autor, não havia se empreendido, até aquele momento, nenhum estudo da sistematização principiológica inerente à matéria, “(...) encontrando-se apenas, de maneira esparsa e assistemática, conforme as circunstâncias, a referência específica a um determinado princípio, que se põe na raiz do tema desenvolvido, garantindo-lhe a validade". ${ }^{179}$

José CRETELLA JR. defendia a principiologia ou sistematização dos princípios como “(...) preliminar necessária, num dado momento da elaboração científica, quando certa disciplina supera a fase empírica, estruturando-se em plano mais rigoroso". ${ }^{180}$ Com apoio em Miguel REALE, explicava que "[t]ôda e qualquer ciência implica na existência de princípios (...)", ${ }^{181}$ sendo “(...) uns universais ou onivalentes (ou seja, comuns a todas as ciências); outros, regionais ou plurivalentes (comuns a um grupo de ciências) e outros,

\footnotetext{
${ }^{173}$ Cf. Celso Antônio BANDEIRA de MELLO. Elementos de direito administrativo. p. 22.

${ }^{174}$ Celso Antônio BANDEIRA de MELLO. Elementos de direito administrativo. p. 22.

${ }^{175}$ Celso Antônio BANDEIRA de MELLO. Elementos de direito administrativo. p. 22.

${ }^{176}$ Celso Antônio BANDEIRA de MELLO. Elementos de direito administrativo. p. 22.

177 José CRETELLA JR.. Princípios informativos do direito administrativo. in Revista de Direito Administrativo, vol. 93. p. 1-10.

178 José CRETELLA JR.. Princípios informativos do direito administrativo. in Revista de Direito Administrativo, vol. 93. p. 2.

179 José CRETELLA JR.. Princípios informativos do direito administrativo. in Revista de Direito Administrativo, vol. 93. p. 2.

180 José CRETELLA JR.. Princípios informativos do direito administrativo. in Revista de Direito Administrativo, vol. 93. p. 2.

${ }^{181}$ Miguel REALE. Filosofia do Direito. p. 55. apud José CRETELLA JR.. Princípios informativos do direito administrativo. in Revista de Direito Administrativo, vol. 93. p. 3.
} 
ainda, monovalentes, por só servirem de fundamento a um único campo de enunciados"; ${ }^{182}$ Por conseguinte, consignava à hierarquia principiológica ora descrita, a inserção de outros princípios, reguladores dos setores específicos de cada ciência, os denominados princípios setoriais. $^{183}$

Prosseguindo, à luz de sua construção metodológica, José CRETELLA JR., classificava o direito administrativo, portanto, como setor específico, parte integrante do direito público; e, pela referida classificação, fazia transparecer a importância do princípio da supremacia do interesse público sobre o particular não como princípio setorial do direito administrativo, mas, do direito público como um todo:

"Êste princípio, princípio da supremacia do interesse público, que informa todo o direito administrativo, norteando a ação dos agentes na edição dos atos administrativos e dos órgãos legiferantes nos processos nomogenéticos, de maneira alguma é princípio setorial, típico, específico do direito administrativo, porque é comum a todo o direito público, em seus diferentes desdobramentos, já que se encontra na base de toda processualística, bem como na raiz do direito penal e do constitucional.

Não há lei que não atenda ao interêsse coletivo; não há processo que não procure concretizar o equilíbrio social, dando razão a quem a tem, mediante a efetivação de medidas indiscriminatórias, que afastam a pretensão pessoal, quando esta não coincide com o ideal-arquétipo de justiça eleito pela coletividade a que pertençam os demandantes; não há, mesmo nos atos administrativos de caráter individual, a ausência da supremacia do público sobre o privado". ${ }^{184}$

Fundado, pois, no raciocínio ora colacionado, José CRETELLA JR. não concebia o princípio da supremacia do interesse público sobre o particular senão como "matriz suprema orientadora" ${ }^{185}$ de qualquer construção publicística, da qual todos os outros postulados “(...) se afirmam como corolários ou escólios, dispostos em pontos mais baixos da pirâmide principiológica (...)" formando, ao lado do princípio da legalidade, a base de

${ }^{182}$ Miguel REALE. Filosofia do Direito. p. 55. apud José CRETELLA JR.. Princípios informativos do direito administrativo. in Revista de Direito Administrativo, vol. 93. p. 3.

${ }^{183}$ Miguel REALE. Filosofia do Direito. p. 56. apud José CRETELLA JR.. Princípios informativos do direito administrativo. in Revista de Direito Administrativo, vol. 93. p. 3.

184 José CRETELLA JR.. Princípios informativos do direito administrativo. in Revista de Direito Administrativo, vol. 93. p. 4.

185 José CRETELLA JR.. Princípios informativos do direito administrativo. in Revista de Direito Administrativo, vol. 93. p. 2. 
sua teoria de regime jurídico de direito público, então maturada por publicações posteriores ${ }^{186}$ até ser definitivamente consolidada na primeira edição da obra "Filosofia do direito administrativo", ${ }^{187}$ publicada no ano de 1999.

Por esta linha de evolução doutrinária, não se questiona a influência exercida pela metodologia de José CRETELLA JR. sobre o pensamento de Maria Sylvia Zanella DI PIETRO, eis que, também para a autora, os princípios da supremacia do interesse público sobre o particular e da legalidade - promanados da “(...) assinalada bipolaridade do Direito Administrativo - liberdade do indivíduo e autoridade da Administração (...)" ${ }^{\text {188 }}$ “(...) não são específicos do Direito Administrativo porque informam todos os ramos do direito público; no entanto, são essenciais, porque a partir deles, constroem-se todos os demais". 189

Maria Sylvia Zanella DI PIETRO, vale dizer, entra no rol de doutrinadores que se dispuseram a estudar o princípio da supremacia do interesse público sobre o particular, de forma mais profunda. Assim o fez ao agregar, no bojo da tese então desenvolvida para o concurso em que fora admitida como Professora Titular de Direito Administrativo da Faculdade de Direito da Universidade de São Paulo, publicada como "Discricionariedade administrativa na Constituição de 1988", ${ }^{190}$ no ano de 1991, um capítulo inteiro para a investigação do tema. $\mathrm{O}$ aspecto de maior destaque de sua teorização, no entanto, não é o principiológico, mas, sim, o enfoque sobre as dificuldades conceituais que giram em torno da expressão interesse público.

Neste sentido, em apertada síntese do estudo acima mencionado, pode-se dizer que a autora, logo de início, por linhas de uma perspectiva histórica, busca identificar a noção de interesse público com a ideia de bem comum; ${ }^{191}$ adiante, examina as percepções

\footnotetext{
186 Neste sentido, à guisa de uma perspectiva histórico-evolutiva das ideias desenvolvidas pelo autor, num processo em que ele realmente ajudou a "construir" o direito administrativo brasileiro, ver, entre outras de suas obras: José CRETELLA JR.. Dicionário de direito administrativo. Rio de Janeiro: Forense. 1978. José CRETELLA JR.. Direito administrativo brasileiro, Volume I. Rio de Janeiro: Forense. 1983.

${ }^{187}$ José CRETELLA JR.. Filosofia do direito administrativo. Rio de Janeiro: Forense. 1999.

${ }^{188}$ Maria Sylvia Zanella DI PIETRO. Direito administrativo. p. 64.

${ }^{189}$ Maria Sylvia Zanella DI PIETRO. Direito administrativo. p. 64.

190 Maria Sylvia Zanella DI PIETRO. Discricionariedade administrativa na Constituição de 1988. São Paulo: Atlas. 1991.

191 Cf. Maria Sylvia Zanella DI PIETRO. Discricionariedade administrativa na Constituição de 1988. p. 153-170. Para a autora, na identificação da concepção de interesse público com a ideia de bem comum existe uma indissociável preocupação com a dignidade do ser humano. Por isso, "[e]sse é o tipo de colocação que melhor se adapta à noção de Estado Social de Direito, que veio substituir o Estado Liberal de Direito. (...)
} 
apresentadas pelos autores Carl Joachim FRIEDRICH, Dalmo de Abreu DALLARI, Ernest Stacey GRIFFITH e Gerhard COLM quanto às dificuldades inerentes à delimitação do termo investigado; ${ }^{192}$ e ao final, trata da questão do controle judicial do interesse público, sustentando que este, em face da normatividade gerada pela Constituição Federal de 1988, encontra-se sempre protegido por outros princípios, sobretudo os da finalidade, ${ }^{193}$ legalidade e impessoalidade. ${ }^{194}$ Antes deste desfecho, contudo, passa a estabelecer, dentro da temática examinada, uma série de distinções necessárias para o isolamento do conceito de interesse público em relação a outras noções correlatas: a primeira delas, consistindo em diferenciá-lo do interesse da administração, já que a expressão interesse público deve referir-se “(...) aos beneficiários da atividade administrativa e não aos entes que a exercem;"195 a segunda, tratando de separá-lo do chamado interesse comum, posto que ao se dizer “(...) que a Administração Pública deve observar o interesse público, não significa que deve atender ao interesse comum a todos os cidadãos, porque isto seria difícil, senão impossível,"196 devendo ela, por isso, “(...) atuar, justificadamente, de modo a beneficiar uma coletividade de pessoas que tenham interesses comuns, ainda que esses interesses não correspondam à soma dos interesses individuais"; ${ }^{197}$ e derradeiramente, a terceira, colocando-o como gênero abrangente de três modalidades: "o interesse geral, afeto a toda a sociedade; o interesse difuso, pertinente a um grupo de pessoas caracterizadas pela indeterminação e indivisibilidade; e o interesse coletivo, que diz respeito a um grupo de pessoas determinadas ou determináveis". 198

Ainda sob a lógica evolutiva até aqui proposta, o que, neste momento, segue implícito, todavia, precisa ser observado é que a referida obra de Maria Sylvia Zanella DI

\footnotetext{
Vale dizer que o Estado Social tem que assegurar aos indivíduos condições no campo da saúde, do trabalho, da educação, da moradia, da alimentação, que lhes permitam viver com dignidade e realizar plenamente a sua liberdade". in Maria Sylvia Zanella DI PIETRO. Discricionariedade administrativa na Constituição de 1988. p. 158.

192 Para aprofundamento quanto à diversidade de critérios sugeridos, por todos os autores citados, para a delimitação da noção de interesse público, ver Maria Sylvia Zanella DI PIETRO. Discricionariedade administrativa na Constituição de 1988. p. 158-163.

193 Cf. Maria Sylvia Zanella DI PIETRO. Discricionariedade administrativa na Constituição de 1988. p. 167-168.

194 Cf. Maria Sylvia Zanella DI PIETRO. Discricionariedade administrativa na Constituição de 1988. p. 168-170.

${ }^{195}$ Maria Sylvia Zanella DI PIETRO. Discricionariedade administrativa na Constituição de 1988. p. 163.

${ }^{196}$ Maria Sylvia Zanella DI PIETRO. Discricionariedade administrativa na Constituição de 1988. p. 165.

${ }^{197}$ Maria Sylvia Zanella DI PIETRO. Discricionariedade administrativa na Constituição de 1988. p. 165.

${ }^{198}$ Maria Sylvia Zanella DI PIETRO. Discricionariedade administrativa na Constituição de 1988. p. 165.
} 
PIETRO, em certa medida, ajuda a inaugurar um novo paradigma, confluente de dois fatores, para o estudo do direito administrativo, a saber: de um lado, o acolhimento da decantada preocupação metodológica, de Celso Antônio BANDEIRA de MELLO e José CRETELLA JR, segundo a qual o direito administrativo deve ser estudado a partir de uma principiologia própria; e de outro, a obrigatoriedade da observância ao novo regramento trazido pela Constituição Federal de 1988, nela introduzida o seu capítulo específico sobre a Administração Pública, com a positivação dos princípios a ela impostos, especificamente, pelos dizeres do artigo 37, caput.

Note-se que esse paradigma, portanto, marca a produção bibliográfica de direito administrativo da década de 1990. É neste período, pois, que os manuais e cursos administrativistas, via de regra, passam a adotar o estudo sistemático dos princípios característicos do direito administrativo, em definitivo. Cada um a sua maneira, ${ }^{199}$ os autores começam a assumir a sistematização dos chamados princípios gerais do direito público, bem como dos princípios da Administração Pública, expressamente previstos no já mencionado artigo 37, caput, do texto magno; ora enumerando-os dentro de capítulos propriamente designados para a descrição dos "princípios do direito administrativo", ora articulando-os em outros capítulos, em geral, explicativos da noção regime jurídicoadministrativo propriamente dito.

De qualquer forma, cumpre registrar que a sempre reconhecida importância do princípio da supremacia do interesse público sobre o particular, antes, assistematicamente abordada pela doutrina administrativista brasileira, a partir da década de 1990 passará a ser incorporada por uma específica racionalidade dogmática, isto é, por uma metodologia de teorização própria do estudo do direito administrativo, adotada por grande parcela dos mais renomados doutrinadores de direito administrativo deste país.

Neste ponto, alguns exemplos podem ser mencionados, como o do autor Diogenes GASPARINI que, na segunda edição do seu prestigiado "Direito administrativo", 200

\footnotetext{
${ }^{199}$ Como bem observado por Mateus Eduardo Siqueira Nunes BERTONCINI que, citando também outros autores, explica: "[n]a doutrina (...), denota-se que diversos autores divergem quanto aos princípios de direito administrativo brasileiro. Essas diferenças são de várias ordens, como, por exemplo, quanto ao número de princípios, quanto à terminologia empregada, quanto ao conteúdo deles, e até mesmo quanto à fonte dessas normas. Como lembra Odete Medauar, "o rol dos princípios do direito administrativo não é idêntico nos diversos ordenamentos e na doutrina". Celso Ribeiro Bastos também observou que "os autores não se põem de acordo sobre o número exato desses princípios e também sobre a sua identidade". in Mateus Eduardo Siqueira Nunes BERTONCINI. Princípios de direito administrativo brasileiro. p. 201.

${ }^{200}$ Diogenes GASPARINI. Direito administrativo. 2 ed. São Paulo: Saraiva. 1992.
} 
publicado em 1992, analisa o princípio da supremacia do interesse público sobre o particular - devidamente posicionado dentro do capítulo intitulado "Princípios informativos do direito administrativo" -, com os seguintes comentários:

\begin{abstract}
"No embate entre os interesses público e particular há de prevalecer o interesse público. Esse o grande princípio informativo do Direito Público no dizer de José Cretella Júnior (Tratado, cit., v. 10, p. 39) Com efeito, nem mesmo se pode imaginar que o contrário possa acontecer, isso é, que o interesse de um ou de um outro grupo possa vingar sobre o interesse de todos. Assim ocorre na desapropriação, na rescisão por mérito de certo contrato administrativo e na imposição de obrigações aos particulares por ato unilateral da Administração Pública, a exemplo da servidão administrativa.

A aplicabilidade desse princípio, por certo, não significa o total desrespeito ao interesse privado, já que a Administração deve obediência ao direito adquirido, à coisa julgada e ao ato jurídico perfeito, consoante prescreve a Lei Maior da Nação (art. $5^{\circ}, \mathrm{XXXVI).}$ De sorte que os interesses patrimoniais afetados pela prevalência do interesse público devem ser indenizados cabalmente". ${ }^{201}$
\end{abstract}

Continuando, dois anos depois, verifica-se a teorização do postulado em tela, também, no "Curso de direito administrativo", ${ }^{202}$ publicado por Lúcia Valle FIGUEIREDO. Por esta obra, define-se a expressão regime jurídico-administrativo como "conjunto de regras e princípios a que se deve subsumir a atividade administrativa no atingimento de seus fins". ${ }^{203} \mathrm{Na}$ sequência, integrada como um dos princípios essenciais deste sistema, a supremacia do interesse público sobre o particular é sintetizada pela autora, com a seguinte premissa: “[s]e é o interesse público que está em jogo, portanto, de toda a coletividade, é lógico deva ele prevalecer sobre o privado (...)". ${ }^{204}$

Destarte, também de 1994 data a publicação do "Curso de direito administrativo", ${ }^{205}$ de Celso Ribeiro BASTOS; obra que enumera os "Princípios do direito administrativo" e os define como critérios informadores desta disciplina jurídica. ${ }^{206}$ Para o

\footnotetext{
${ }^{201}$ Diogenes GASPARINI. Direito administrativo. 2 ed. p. 14-15.

${ }^{202}$ Lúcia Valle FIGUEIREDO. Curso de direito administrativo. São Paulo: Malheiros. 1994.

${ }^{203}$ Lúcia Valle FIGUEIREDO. Curso de direito administrativo. p. 33.

${ }^{204}$ Lúcia Valle FIGUEIREDO. Curso de direito administrativo. p. 34.

${ }^{205}$ Celso Ribeiro BASTOS. Curso de direito administrativo. São Paulo: Saraiva. 1994.

${ }^{206}$ Cf. Celso Ribeiro BASTOS. Curso de direito administrativo. p. 23.
} 
autor, a supremacia do interesse público sobre o particular é um desses princípios e por ele, o interesse coletivo sobrepõe-se ao individual sem que o chamado Estado de Direito seja violado. Ademais, Celso Ribeiro BASTOS sustenta que o direito administrativo, justamente por enfeixar um conjunto de normas voltadas para a realização dos fins públicos, é que se apresenta dotado de prerrogativas como “(...) o poder de polícia, a faculdade de desapropriar, de requisitar, de impor unilateralmente obrigações aos particulares, os prazos especiais de que desfruta quando em juízo", ${ }^{207}$ etc; e destaca, em conclusão de raciocínio, que estas manifestações de uma posição privilegiada não representam a consagração do arbítrio, mesmo que este, supostamente, se mostre justificado pela consecução de um interesse coletivo. ${ }^{208}$

Com efeito, outro aspecto a ser realçado do pensamento de Celso Ribeiro BASTOS é a sua preocupação em identificar “(...) o que seja um autêntico interesse coletivo", haja vista que no seu entender, muitas vezes a Administração Pública não age em nome de interesses próprios da coletividade, mas, de interesses que só lhes são atinentes na posição de mera pessoa jurídica, daí também decorrendo situações de irrazoabilidade. Em tais casos, o autor assevera que “(...) não há que se falar em supremacia do interesse coletivo, porque há total possibilidade de o Estado submeter-se a igual direito dos particulares sem quebra ou prejuízo do atingimento dos fins coletivos". ${ }^{209}$

Outrossim, Celso Ribeiro BASTOS explica:

"Portanto, o fato legitimador da utilização da supremacia do interesse público reside exatamente na persecução daqueles interesses que não dizem respeito à pessoa jurídica enquanto tal, mas que se traduz em objetivos a serem por ela procurados. Para a viabilização, a concretização desses objetivos, que dizem respeito à coletividade e não especificamente a este ou àquele indivíduo, é que se legitima a posição de superioridade que, contudo, há de manter uma relação de razoabilidade entre o fim que vai atingir e o dano que vai causar. Não se pode, em nome do interesse coletivo, editar uma lei, por exemplo, para melhor segurança da saúde pública, que imponha a morte e o enterro rápido de pessoa atingida com uma doença contagiosa. (...)

\footnotetext{
${ }^{207}$ Celso Ribeiro BASTOS. Curso de direito administrativo. p. 30.

${ }^{208}$ Cf. Celso Ribeiro BASTOS. Curso de direito administrativo. p. 30.

${ }^{209}$ Celso Ribeiro BASTOS. Curso de direito administrativo. p. 31.
} 
Há de haver logicamente como princípio, não só de direito administrativo mas de direito em geral, uma razoabilidade na feitura das leis administrativas de tal sorte que o sacrifício imposto ao particular seja de natureza compatível com a finalidade coletiva que vai ser atingida. Não é um miúdo interesse ainda que coletivo mas hierarquicamente bastante subalterno diante dos fins administrativos, que podem justificar a imposição de sacrifícios de direitos substanciais da pessoa, tais como a liberdade, a propriedade e a própria vida". 210

E sem embargo, mas tão somente à guisa de um último exemplo a ser agregado a esta lista de autores que impulsionaram o estudo principiológico do direito administrativo na década de 1990, cabe lembrar de Toshio MUKAI e sua obra "Direito administrativo sistematizado", ${ }^{211}$ publicada em 1999. Neste livro, diz o autor:

"Para nós, a construção de um conceito racional de direito deve fundar-se, ou pelo menos deve ser estruturada, a partir do estudo de sua principiologia específica e da concretização desses princípios.

Para o regime jurídico-administrativo interessam aquelas normas jurídicas que visam à concretização de interesses públicos. Para tanto, umas concedem ao Estado posição de supremacia ante o particular, sem o que não seria possível o atendimento daqueles interesses; outras, sem essa característica, no entanto, igualmente visam o atendimento de finalidades impessoais, interessantes para o bem comum, e basta, então, nesse caso, uma relação de quase igualdade das partes.

Interesse público (ou utilidade pública) é a expressão-chave do conceito de Direito Administrativo, pois dela fazem parte pelo menos dois dos mais importantes princípios gerais caracterizadores do regime jurídico-administrativo: o da indisponibilidade do interesse público e o da prevalência do interesse público sobre o particular". ${ }^{212}$

E termina, definindo o que chama de "Primazia do interesse público” como “(...) o princípio que domina toda a atuação estatal, pois o Estado existe para isso - para satisfazer o interesse público". ${ }^{213}$

\footnotetext{
${ }^{210}$ Celso Ribeiro BASTOS. Curso de direito administrativo. p. 31.

${ }^{211}$ Toshio MUKAI. Direito administrativo sistematizado. São Paulo: Saraiva. 1999.

${ }^{212}$ Toshio MUKAI. Direito administrativo sistematizado. p. 12-13.

${ }^{213}$ Toshio MUKAI. Direito administrativo sistematizado. p. 13.
} 
Como se vê, o pensamento de Toshio MUKAI não traz significativas divergências em relação aos pensamentos dos outros autores acima colacionados.

Para finalizar, percebe-se que todas as passagens doutrinárias até aqui apresentadas acabam por cumprir o escopo deste capítulo à medida que descrevem a trilha evolutiva através da qual a teoria do princípio da supremacia do interesse público sobre o particular, hoje, posta em debate, fora construída pela doutrina administrativista brasileira no decorrer de sua história.

As linhas gerais deste debate, com efeito, serão delineadas no próximo capítulo. 


\section{AS LINHAS GERAIS DO DEBATE DOUTRINÁRIO DO PRINCÍPIO DA SUPREMACIA DO INTERESSE PÚBLICO SOBRE O PARTICULAR NO DIREITO ADMINISTRATIVO BRASILEIRO}

\subsection{Contextualização jurídica do debate: o sentido principiológico da constitucionalização do direito administrativo no Brasil}

Restam, ainda, questões preliminares à compreensão do debate que será investigado: quais são as circunstâncias jurídicas que provocam as divergências teóricas acerca do principio da supremacia do interesse público sobre o particular no direito administrativo brasileiro atual? Em que ambiente normativo ocorre esse confronto de argumentos doutrinários? O que, especificamente, tem instigado os doutrinadores a escreverem sobre o tema?

Tais indagações - dentre outras que, no mesmo sentido, poderiam ser formuladas - reclamam a necessidade de uma exposição contextual, como componente descritivo do objeto em estudo. A finalidade deste tópico, por isso, consiste em apresentar uma linha ainda que breve - de contextualização jurídica plausível para que o aludido debate possa ser compreendido dentro de um quadro fenomênico que lhe confira racionalidade.

Essa linha tem, em sua origem, a pressuposição de que, mesmo a despeito do histórico doutrinário até aqui relatado, ${ }^{214}$ seria ilusório imaginar a consolidação teórica do princípio da supremacia do interesse público sobre o particular no direito administrativo brasileiro, desacompanhada de questionamentos filiados a correntes de pensamento dissonantes do padrão metodológico paulatinamente convencionado para o estudo da matéria. $^{215}$

Como se sabe, os questionamentos postulam mudanças.

\footnotetext{
${ }^{214}$ Ver principalmente, no segundo capítulo desta pesquisa, os tópicos 2.5. e 2.6. retro.

${ }^{215}$ Crítica bastante contundente a este padrão metodológico é a externada por Gustavo BINENBOJM. O autor trata como "vícios de origem" o que chama de "a crise dos paradigmas do direito administrativo". in. Gustavo BINENBOJM. Uma teoria do direito administrativo: direitos fundamentais, democracia $e$ constitucionalização. p. 23.
} 
É que o direito administrativo, em verdade, sempre foi assim. Parafraseando Maria Sylvia Zanella DI PIETRO, “[o] direito administrativo mal tinha nascido e já León Duguit escrevia o seu conhecido trabalho sobre Les transformations du droit public, ${ }^{216} \mathrm{de}$ 1913". ${ }^{217}$ Sem embargo, a autora ainda elenca outras obras e autores ${ }^{218}$ para demonstrar que, de maneira geral, os fundamentos teóricos do direito administrativo sempre estiveram envoltos por indagações, crises e tendências transformadoras.

$\mathrm{Na}$ doutrina, diversos fatores costumam ser mencionados para justificar as inovações - ou, pelo menos, as propostas inovadoras - que movimentam o direito administrativo na atualidade.

Em sentido abrangente e falando sobre “(...) os fatores que mais afetaram a modelagem do Estado na década de 90 do século XX e [que] se projetam para o início do século XXI", ${ }^{219}$ Odete MEDAUAR cita e discorre sobre os fenômenos da globalização, ${ }^{220} \mathrm{do}$ neoliberalismo ${ }^{221}$ e da privatização. ${ }^{222}$

\footnotetext{
${ }^{216}$ León DUGUIT. Les transformations du droit public. Paris: Armand Colin, 1913.

${ }^{217}$ Maria Sylvia Zanella DI PIETRO. Introdução: existe um novo direito administrativo? in. Maria Sylvia Zanella DI PIETRO e Carlos Vinícius Alves RIBEIRO (coord.). Supremacia do interesse público e outros temas relevantes do direito administrativo. p. 4.

${ }^{218}$ Sobre os autores e obras citadas, ver Maria Sylvia Zanella DI PIETRO. Introdução: existe um novo direito administrativo? in. Maria Sylvia Zanella DI PIETRO e Carlos Vinícius Alves RIBEIRO (coord.). Supremacia do interesse público e outros temas relevantes do direito administrativo. p. 4.

${ }^{219}$ Odete MEDAUAR. O direito administrativo em evolução. p. 93.

220 "Em essência, a globalização caracteriza-se pela transnacionalização acelerada dos mercados, dos capitais, da produção, das relações econômicas, do consumo, sem limites territoriais. Ocorre a superação das restrições de espaço e tempo, ante a capacidade de tratamento instantâneo de um grande volume de informações, acarretando, inclusive, rápidos movimentos transnacionais de capital financeiro. (...) $\mathrm{O}$ fenômeno, que seria substancialmente econômico, traz fortes repercussões no âmbito político, social, jurídico e em vários outros". in Odete MEDAUAR. O direito administrativo em evolução. p. 94.

221 "Embora globalização e neoliberalismo não sejam necessariamente vinculados do ponto de vista teórico, vêm sendo associados a partir de meados da década de 90 do século XX. Esse neoliberalismo também foi ligado ao Consenso de Washington, expressão cunhada pelo economista John Williamson, no fim da década de 80 do século XX, e por instituições financeiras sediadas na capital dos Estados Unidos, para designar um conjunto de ideias em favor da economia de mercado, sintetizadas no seguinte: disciplina macroeconômica, economia de mercado, abertura comercial. Ligadas ao neoliberalismo resultaram as diretrizes de: fortalecimento dos mercados privados; desregulamentação da economia, privatização das empresas estatais, liberalização dos mercados, livre comércio internacional, redução da atuação do Estado, controle da inflação, redução do déficit público, corte nas despesas sociais. Adotado pelos Governos de Reagan nos Estados Unidos, e de Margareth Thatcher, na Inglaterra, na década de 80 do século XX, expandiu-se para a Europa e países em desenvolvimento, incentivado por organismos internacionais, como FMI e Banco Mundial”. in Odete MEDAUAR. O direito administrativo em evolução. p. 97.

222 "Os termos privatização, desestatização, liberalização, desregulamentação, desregulação passaram a integrar, na década de 90 do século XX, o vocabulário do direito público, sem muita precisão e por vezes como sinônimos. Neste item, sem adentrar nos aspectos conceituais desses termos, utiliza-se o termo privatização em sentido amplo, para abarcar todas as medidas pelas quais ocorreu a redução do espaço do
} 
Já em abordagem mais específica e atinente ao cenário brasileiro, Maria Sylvia Zanella DI PIETRO explica que as principais inovações do direito administrativo deste país ocorreram após a promulgação da Constituição Federal de 1988, “(...) seja com a adoção dos princípios do Estado Democrático de Direito, seja sob a inspiração do neoliberalismo e da globalização (...)”, bem como “(...) do sistema da common law e do direito comunitário europeu, que levaram à chamada Reforma do Estado, na qual se insere a Reforma da Administração Pública e, em consequência, a introdução de novidades no âmbito do direito administrativo". 223

E certamente, tantas foram as "mutações" 224 sofridas pelo direito administrativo, em razão das mudanças normativas estatuídas pela nova constituição promulgada no Brasil, que essas passaram a ser tratadas, no âmbito doutrinário, como aspectos ou manifestações características da chamada constitucionalização do direito administrativo. ${ }^{225}$

A modo geral, observa-se que falar sobre a constitucionalização do direito administrativo - sobretudo, quando em sua "tela de pintura" são realçadas as "cores" da inovação e do ineditismo jurídicos - é, em alguma medida, tratar de uma temática delicada e até paradoxal: primeiro, porque o direito constitucional e o direito administrativo

Estado na sociedade, com a transferência, total ou parcial, de atividades ao setor privado e com a menor ascendência do Estado em vários âmbitos da sociedade, como por exemplo: venda de estatais, quebra de monopólios públicos, forte utilização das concessões e permissões de serviços público, aumento das parcerias público-privado, suavização das formas de intervenção estatal na economia, incentivo à auto-regulação, estímulo à maior atuação dos particulares na área social (grande desenvolvimento do chamado terceiro setor)". in Odete MEDAUAR. O direito administrativo em evolução. p. 97.

223 A autora não deixa de mencionar, também “(...) a influência de princípios da ciência econômica e da ciência da administração no direito administrativo, com duas consequências: de um lado, a formação do chamado direito administrativo econômico (em relação ao qual o direito administrativo tradicional é chamado, pejorativamente, de conservador ou, mesmo, ultrapassado) e, de outro lado, a preocupação com princípios técnicos, mais próprios da ciência da administração, significando um retorno a uma fase anterior em que já houve a confusão entre os institutos e princípios jurídicos, próprios do direito, e os aspectos puramente técnicos, mais ligados à ciência da administração". p. 27. in Maria Sylvia Zanella DI PIETRO. Direito administrativo. p. 27.

${ }^{224}$ Aqui a referência é clara e homenageia o professor Diogo de Figueiredo MOREIRA NETO, autor da locução que dá nome a sua obra Mutações do direito administrativo, publicada pela editora Renovar.

${ }^{225}$ Referida temática passa a ser intensamente discutida por diversos trabalhos, entre eles: Regina Maria Macedo Nery FERRARI. A constitucionalização do direito administrativo e políticas públicas. in A\&C Revista de Direito Administrativo \& Constitucional, ${ }^{\circ}$. 40. p. 271-290.; Cristiana Corrêa Conde FALDINI. A constitucionalização do direito administrativo. in. Maria Sylvia Zanella DI PIETRO e Carlos Vinícius Alves RIBEIRO (coord.). Supremacia do interesse público e outros temas relevantes do direito administrativo. p. 261-277.; Luís Roberto BARROSO. A constitucionalização do direito e suas repercussões no âmbito administrativo. in Alexandre Santos de ARAGÃO; Floriano Peixoto de Azevedo MARQUES NETO (coord.). Direito administrativo e seus novos paradigmas. p. 31-64.; e etc. 
surgiram juntos e sob inspiração dos mesmos ideais; ${ }^{226}$ e segundo, porque a expressão em tela admite variadas significações ou sentidos de abordagem.

Objetivamente, quanto à primeira nuance deste paradoxo, extrai-se do pensamento de Maria Sylvia Zanella DI PIETRO que, também no caso brasileiro, a constitucionalização do direito administrativo é, sim, uma realidade, porém não deve ser considerada como um dado novo, já que “(...) ela sempre existiu, ${ }^{227}$ em maior ou menor grau, em praticamente todas as Constituições e vem crescendo até o momento atual, especialmente por força de Emendas à Constituição";228 quanto à segunda, tem-se, em passo didático para os fins do presente trabalho, que a questão pode ser divisada por uma classificação bastante conhecida, proposta por Luís Roberto BARROSO:

"Na quadra presente, três conjuntos de circunstâncias devem ser considerados no âmbito da constitucionalização do direito administrativo: a) a existência de uma vasta quantidade de normas constitucionais voltadas para a disciplina da Administração Pública; b) a sequência de transformações sofridas pelo Estado brasileiro nos últimos anos; c) a influência dos princípios constitucionais sobre as categorias do direito administrativo". 229

Ainda tendo por base a classificação ora colacionada, impõe-se não perder de vista a importância conferida ao terceiro conjunto de circunstâncias acima arrolado, isto é,

\footnotetext{
226 Cf. Alexandre de MORAES: "Interessante notar que o surgimento do Direito Administrativo é contemporâneo ao do Direito Constitucional, enquanto forma de organização do Estado, pois a mesma ideia que fez florescer o constitucionalismo moderno consagrou a autonomia do Direito Administrativo, qual seja a necessidade de limitação e controle dos abusos de poder do próprio Estado e de suas autoridades constituídas e a consagração dos princípios básicos da igualdade e da legalidade como regentes do Estado". In Alexandre de MORAES. Constitucionalização do direito administrativo e princípio da eficiência. in. Carlos Maurício FIGUEIREDO e Marcos NÓBREGA (org.). Direito administrativo, financeiro e gestão pública: prática, inovações e problemas. p. 26-27.

${ }^{227}$ Ainda, segundo a autora, mas em passagem diversa: “(...) especialmente a partir da Constituição de 1934, onde se encontram normas sobre servidor público, responsabilidade civil do Estado, desapropriação, mandado de segurança, ação popular, atribuição de atividades à competência exclusiva da União, previsão de lei sobre concessão de serviços públicos”. Maria Sylvia Zanella DI PIETRO. Da constitucionalização do direito administrativo: reflexos sobre o princípio da legalidade e a discricionariedade administrativa. in. Maria Sylvia Zanella DI PIETRO e Carlos Vinícius Alves RIBEIRO (coord.). Supremacia do interesse público e outros temas relevantes do direito administrativo. p. 179.

${ }^{228}$ Maria Sylvia Zanella DI PIETRO. Da constitucionalização do direito administrativo: reflexos sobre o princípio da legalidade e a discricionariedade administrativa. in. Maria Sylvia Zanella DI PIETRO e Carlos Vinícius Alves RIBEIRO (coord.). Supremacia do interesse público e outros temas relevantes do direito administrativo. p. 180.

${ }^{229}$ Luís Roberto BARROSO. Neoconstitucionalismo e constitucionalização do direito (o triunfo tardio do direito constitucional no Brasil). in Revista Trimestral de Direito Público, ed. 44. p. 42.
} 
ao sentido principiológico da chamada constitucionalização do direito administrativo, enquanto preferência viva na comunidade jurídica, que se manifesta seja no manuseio dos discursos forenses, seja no desenvolvimento dos estudos doutrinários. ${ }^{230}$ Aliás, neste sentido, as próprias palavras de Luís Roberto BARROSO sinalizam o entusiasmo do meio jurídico em relação à constitucionalização dos princípios que regem a atuação da Administração Pública e, ao mesmo tempo, consagram a observância dos direitos fundamentais do homem:

\begin{abstract}
"Por fim, mais decisivo que tudo para a constitucionalização do direito administrativo, foi a incidência no seu domínio dos princípios constitucionais - não apenas os específicos, mas sobretudo os de caráter geral, que se irradiam por todo o sistema jurídico. Também aqui, a partir da centralidade da dignidade da pessoa humana e da preservação dos direitos fundamentais, alterou-se a qualidade das relações entre Administração e administrado, com a superação ou reformulação dos paradigmas tradicionais". ${ }^{231}$
\end{abstract}

Revela-se, portanto, uma nova tendência: a da "superação ou reformulação dos paradigmas tradicionais". Por este prisma, Gustavo BINENBOJM, a exemplo de tantos outros autores, ${ }^{232}$ defenderá a releitura dos mais basilares fundamentos teóricos do direito administrativo, “(...) buscando não só evitar conflitos com a Lei Maior, mas também potencializar os valores e objetivos que esta consagra". ${ }^{233}$ Seus argumentos seguirão a ideia da constitucionalização do direito administrativo como alternativa a um quadro de paradigmas teoricamente deficitário do direito administrativo tradicional, porquanto

\footnotetext{
230 Não por acaso, Carlos Ari SUNDFELD menciona "[a] moda dos princípios no direito público", em abordagem crítica e reflexiva sobre o tema. in Carlos Ari SUNDFELD. Princípio é preguiça? in Carlos Ari SUNDFELD. Direito administrativo para céticos. p.60-84.

${ }^{231}$ Luís Roberto BARROSO. Neoconstitucionalismo e constitucionalização do direito (o triunfo tardio do direito constitucional no Brasil). in Revista Trimestral de Direito Público, ed. 44. p. 43.

232 Tais como: Patrícia BAPTISTA. Transformações do direito administrativo. Rio de Janeiro: Renovar. 2003.; Diogo de Figueiredo MOREIRA NETO. Quatro paradigmas do direito administrativo pós-moderno. Belo Horizonte: Fórum. 2008.; Marçal JUSTEN FILHO. O direito administrativo de espetáculo. in Alexandre Santos de ARAGÃO; Floriano Peixoto de Azevedo MARQUES NETO (coord.). Direito administrativo e seus novos paradigmas. p. 65-86. e etc

233 Gustavo BINENBOJM. Uma teoria do direito administrativo: direitos fundamentais, democracia $e$ constitucionalização. p. 65.
} 
incompatível com a principiologia irradiada pela Constituição Federal de 1988, de teleologia notadamente democrática. ${ }^{234}$

Ganham respaldo teórico, assim, as críticas lançadas contra a supremacia do interesse público sobre o particular, em razão da importância deste princípio como eixo estruturante da teoria geral do direito administrativo no Brasil. O contexto, conforme aduz Irene Patrícia NOHARA, é o “(...) da delimitação de novas tendências no direito no Direito Administrativo, que foram consequências do advento do Estado Democrático de Direito e da necessidade de superação de diversos paradigmas positivistas" ${ }^{235} \mathrm{em}$ face, logicamente, da nova tessitura constitucional, neste tópico destacada.

Por outro lado, esse pensamento crítico também passa a ser questionado por uma série de outros doutrinadores, ${ }^{236}$ que buscam apontar os excessos e os vícios argumentativos contidos nesta nova forma de pensar o direito administrativo brasileiro, consistente, conforme ora demonstrado, na supressão de um dos principais pilares de sua teoria geral, o princípio da supremacia do interesse público sobre o particular.

Eis o ambiente em que se desenvolverá o diálogo doutrinário, em análise no tópico a seguir.

\subsection{Apanhado histórico do debate: uma visão panorâmica sobre o diálogo dos doutrinadores}

Nota-se, ultimamente, um significativo aumento de publicações buscando descrever ou relatar este fenômeno que é o debate doutrinário acerca do princípio da

\footnotetext{
234 Cf. Gustavo BINENBOJM. Uma teoria do direito administrativo: direitos fundamentais, democracia e constitucionalização. p. 24-26.

235 Irene Patrícia NOHARA. Reflexões críticas acerca da tentativa de desconstrução do sentido da supremacia do interesse público no direito administrativo. in. Maria Sylvia Zanella DI PIETRO e Carlos Vinícius Alves RIBEIRO (coord.). Supremacia do interesse público e outros temas relevantes do direito administrativo. p. 120.

${ }^{236}$ Maria Sylvia Zanella DI PIETRO. O princípio da supremacia do interesse público: sobrevivência diante dos ideais do neoliberalismo. in Revista Trimestral de Direito Público, ed. 48. p. 63-76.; Fábio Medina OSÓRIO. Existe uma supremacia do interesse público sobre o privado no direito administrativo brasileiro? in Revista dos Tribunais. Vol. 770. p. 53-92.; Daniel Wunder HACHEM. Princípio constitucional da supremacia do interesse público. Belo Horizonte: Fórum. 2011. e etc.
} 
supremacia do interesse público sobre o particular no direito administrativo brasileiro. ${ }^{237}$ Tais abordagens, apesar de quase sempre muito breves, bem sinalizam a necessidade de compreensão da linha de diálogo desenvolvida pelos doutrinadores administrativistas brasileiros quanto ao princípio em pauta até o presente momento.

Nada mais lógico, poderia-se dizer, sobretudo tendo em vista que, se como declara Maria Sylvia Zanella DI PIETRO, "[a]final, é do debate que nasce a luz", ${ }^{238}$ natural, portanto, que atenções sejam voltadas aos conflitos - verdadeiros ou aparentes verificados por toda a extensão interconectiva das fontes de luminosidade.

Numa acepção um pouco distinta da colocada pela autora, porém, seria possível dizer que, no debate em tela, algumas luzes iluminam mais que outras. Decodificando esta metáfora que toma "repercussão" por "iluminação", é de se afirmar, pois, que alguns textos, logicamente, desfrutam de maior repercussão que outros no debate.

A ideia do tópico presente é, como acima enunciado em seu título, fazer um apanhado histórico do debate doutrinário acerca do princípio da supremacia do interesse público sobre o particular no direito administrativo brasileiro através de uma visão panorâmica projetada sobre o diálogo dos doutrinadores. Do alto de onde essa visão se projeta, percebe-se que somente os focos de luminosidade mais intensa podem ser enxergados. Por isso, sem necessariamente adentrar ao mérito de definir quais artigos ou autores são mais ou menos importantes, cumpre neste momento, apenas delinear uma breve cronologia segundo a qual se viabilize, pelo menos, uma noção geral sobre a história deste debate.

E essa história começa em consonância com o que se demonstrou no tópico precedente, isto é, no observado contexto de constitucionalização do direito administrativo

${ }^{237}$ São exemplos de publicações de que, de uma forma ou de outra, fazendo menção a este debate: Ana Cláudia FINGER. O princípio da boa-fé e a supremacia do interesse público - fundamentos da estabilidade do ato administrativo. in Romeu Felipe BACELLAR FILHO; Daniel Wunder HACHEM (coord.). Direito administrativo e interesse público: estudos em homenagem ao professor Celso Antônio Bandeira de Mello. p. 307-346.; Adriana da Costa Ricardo SCHIER. O princípio da supremacia do interesse público sobre o privado e o direito de greve de servidores públicos. in Romeu Felipe BACELLAR FILHO; Daniel Wunder HACHEM (coord.). Direito administrativo e interesse público: estudos em homenagem ao professor Celso Antônio Bandeira de Mello. p. 377-405.; Elói Martins SENHORAS; Ariane Raquel Almeida de SOUZA CRUZ. Debates sobre o princípio da supremacia do interesse público sobre o privado. in Repertório de jurisprudência IOB , n. 24 - vol.I. p. 797-798; entre outros.

${ }^{238}$ Maria Sylvia Zanella DI PIETRO. Introdução: existe um novo direito administrativo? in. Maria Sylvia Zanella DI PIETRO e Carlos Vinícius Alves RIBEIRO (coord.). Supremacia do interesse público e outros temas relevantes do direito administrativo. p. 3. 
brasileiro, quando o movimento doutrinário de crítica ao princípio da supremacia do interesse público sobre o particular fora inaugurado, em 1998, por Humberto Bergmann ÁVILA, em seu artigo "Repensando o princípio da supremacia do interesse público sobre o particular". 239

O genérico convite para o debate contido neste ensaio foi expressamente aceito por Fábio Medina OSÓRIO que, procurando trazer à tona “(...) algumas breves reflexões em torno do problema da superioridade do interesse público sobre o privado no Direito Público brasileiro"240 publicou, no ano seguinte, o artigo "Existe uma supremacia do interesse público sobre o privado no direito brasileiro?"; 241 mesmo ano em que Marçal JUSTEN FILHO, ainda que sem fazer menção a este convite, também arriscou-se a revisar o conceito de interesse público à luz do princípio da dignidade da pessoa humana, em artigo intitulado "Conceito de interesse público e a "personalização" do direito administrativo". 242

Em 2004, tem-se a publicação do artigo "Ensaio sobre o a supremacia do interesse público sobre o privado e o regime jurídico dos direitos fundamentais,", 243 elaborado por Paulo Ricardo SCHIER, em manifesta concordância com as ideias apresentadas no artigo acima mencionado de Humberto Bergmann ÁVILA. Ambos os textos, destarte, passam a integrar a impactante coletânea de artigos organizada por Daniel SARMENTO, publicada sob o nome de "Interesses públicos versus interesses privados: desconstruindo o princípio da supremacia do interesse público"; ${ }^{244}$ pela primeira vez, no ano de 2005. Fazem parte desta obra, ainda, os seguintes ensaios: "A "Supremacia do

\footnotetext{
239 Humberto Bergmann ÁVILA. Repensando o "princípio da supremacia,do interesse público sobre o particular”. in Revista Trimestral de Direito Público , n. 24. p. 159-180.

${ }^{240}$ Fábio Medina OSÓRIO. Existe uma supremacia do interesse público sobre o privado no direito administrativo brasileiro? in Revista dos Tribunais. Vol. 770. p. 58.

241 Fábio Medina OSÓRIO. Existe uma supremacia do interesse público sobre o privado no direito administrativo brasileiro? in Revista dos Tribunais. Vol. 770. p. 53-92.

${ }^{242}$ Marçal JUSTEN FILHO. O conceito de interesse público e a "personalização"do direito administrativo. in Revista Trimestral de Direito Público, n. 26. p. 115-136.

243 Paulo Ricardo SCHIER. Ensaio sobre a supremacia do interesse público sobre o privado e o regime jurídico dos direitos fundamentais. in Revista da Academia Brasileira de Direito Constitucional, v. 5. p. 527 551. Registre-se também, sem embargo, que no mesmo ano, Hidemberg Alves da FROTA publicava em Portugal, na Revista da Faculdade de Direito da Universidade de Lisboa - v. 45. n.1/2. P. 229-250 - o artigo "O princípio da supremacia do interesse público sobre o privado no direito positivo comparado: expressão do interesse geral da sociedade e da soberania popular”.

${ }^{244}$ Daniel SARMENTO (org.). Interesses públicos versus interesses privados:desconstruindo o princípio da supremacia do interesse público. Rio de Janeiro: Lumen Juris. 2005.
} 
interesse público" no advento do Estado de direito e na hermenêutica do direito público contemporâneo", 245 escrito por Alexandre Santos de ARAGÃO; "Da supremacia do interesse público ao dever de proporcionalidade: um novo paradigma para o direito administrativo", 246 de Gustavo BINENBOJM; e "Interesses públicos versus interesses privados na perspectiva da teoria e da filosofia constitucional ", ${ }^{247}$ produzido pelo próprio Daniel SARMENTO.

De outro lado, ainda em 2004, Maria Sylvia Zanella DI PIETRO já redigira o seu artigo denominado "O princípio da supremacia do interesse público: sobrevivência diante dos ideais do neoliberalismo",248 como resposta a tais críticas, que começavam a ganhar força. No ano seguinte, com efeito, o debate então consolidado recebe a atenção de Eunice Ferreira NEQUETE, em pioneira dissertação de mestrado sobre os "Os fundamentos históricos do principio da supremacia do interesse público", ${ }^{249}$ apresentada junto à Universidade Federal do Rio Grande do Sul, ocasião em que a candidata vai pouco além do registro das primeiras divergências teóricas sobre o tema, porém, pelo conjunto da obra, não deixa de ofertar contribuições importantes para os estudos vindouros, de outros juristas. E adiante, no ano de 2006, este debate registra a participação também de Alice Gonzalez BORGES, cuja abordagem procura sustentar um posicionamento intermediário, ou seja, não no sentido de "desconstrução", mas de "reconstrução" do princípio em tela, o que pode ser depreendido do próprio título do artigo publicado por esta autora: "Supremacia do interesse público: desconstrução ou reconstrução?, "250

\footnotetext{
245 Alexandre Santos de ARAGÃO. A “supremacia,do interesse público" no advento do Estado de Direito e na hermenêutica do direito público contemporâneo. in Daniel SARMENTO (org.). Interesses públicos versus interesses privados:desconstruindo o princípio da supremacia do interesse público. p. 1-22.

${ }^{246}$ Gustavo BINENBOJM. Da supremacia do interesse público ao dever de proporcionalidade: um novo paradigma para o direito administrativo. in Daniel SARMENTO (org.). Interesses públicos versus interesses privados:desconstruindo o princípio da supremacia do interesse público. p. 117-169.

${ }^{247}$ Daniel SARMENTO. Interesses públicos vs. interesses privados na perspectiva da teoria e da filosofia constitucional. in Daniel SARMENTO (org.). Interesses públicos versus interesses privados:desconstruindo o princípio da supremacia do interesse público. p. 23-116.

${ }^{248}$ Maria Sylvia Zanella DI PIETRO. O princípio da supremacia do interesse público: sobrevivência diante dos ideais do neoliberalismo. in Revista Trimestral de Direito Público, ed. 48. p. 63-76.

${ }^{249}$ Eunice Ferreira NEQUETE. Fundamentos históricos do princípio da supremacia do interesse público. Dissertação de Mestrado - Porto Alegre: Faculdade de Direito, Universidade Federal do Rio Grande do Sul. 2005.

${ }^{250}$ Alice Gonzalez BORGES. Supremacia do interesse público: desconstrução ou reconstrução? in Revista Interesse Público, n. ${ }^{\circ}$ 37. p. 29-48.
} 
A partir de então, nota-se que diversos novos artigos passam a ser publicados e republicados nos periódicos jurídicos, num movimento de quase massificação do debate acerca do princípio da supremacia do interesse público sobre o particular, por parte da doutrina, até que, no ano de 2008, uma nova coletânea de ensaios jurídicos, esta coordenada por Alexandre Santos de ARAGÃO e Floriano Peixoto de Azevedo MARQUES NETO, volta a impactar o cenário ora descrito, expressamente com a proposta de discutir o "Direito administrativo e seus novos paradigmas". 251 De seu turno, esses novos paradigmas - que logicamente englobam a temática de preservação, desconstrução ou reconstrução do princípio da supremacia do interesse público sobre o particular passam a ser objeto de uma reação doutrinária, que bibliograficamente, aliás, sedimenta também uma nova tendência, a de discutir o futuro do direito administrativo através de obras produzidas coletivamente por vários autores.

Desta feita, para além dos artigos tradicionalmente publicados em periódicos técnicos e especializados, como acima relatado, o debate ora referido passa a ser fomentado também e sobretudo por coletâneas de artigos concernentes ao estudo dos princípios de direito administrativo. ${ }^{252}$ Neste sentido, muito provavelmente em razão da grandiosa polêmica que ao longo dos anos restou-se avolumada desde as críticas pioneiramente lançadas por Humberto Bergmann ÁVILA em 1998, o princípio da supremacia do interesse público acaba por se tornar o objeto central deste tipo de produção doutrinária, conforme é possível perceber, tomando como exemplos as obras "Supremacia do interesse público e outros temas relevantes do direito administrativo", 253 coordenada por Maria Sylvia Zanella DI PIETRO e Carlos Vinícius Alves RIBEIRO; e "Direito administrativo e interesse público: estudos em homenagem ao professor Celso Antônio Bandeira de Mello", 254 coordenada por Romeu Felipe BACELLAR FILHO e Daniel Wunder HACHEM; ambas publicadas no ano de 2010.

\footnotetext{
${ }^{251}$ Alexandre Santos de ARAGÃO; Floriano Peixoto de Azevedo MARQUES NETO (coord.). Direito administrativo e seus novos paradigmas. Belo Horizonte: Fórum. 2008.

${ }^{252}$ Ver, por todos, Thiago MARRARA (org.). Princípios de direito administrativo:legalidade, segurança jurídica, impessoalidade, publicidade, motivação, eficiência, moralidade, razoabilidade, interesse público. São Paulo: Atlas. 2012.

${ }^{253}$ Maria Sylvia Zanella DI PIETRO; Carlos Vinícius Alves RIBEIRO (coord.). Supremacia do interesse público e outros temas relevantes do direito administrativo. São Paulo: Atlas. 2010.

${ }^{254}$ Romeu Felipe BACELLAR FILHO; Daniel Wunder HACHEM (coord.). Direito administrativo $e$ interesse público: estudos em homenagem ao professor Celso Antônio Bandeira de Mello. Belo Horizonte: Fórum. 2010.
} 
E paulatinamente, esse diálogo entre doutrinadores vai se tornando cada vez mais profundo, razão pela qual, recentemente, uma última tendência vem sendo percebida, pois, se antes o princípio da supremacia do interesse público sobre o particular era discutido, a grosso modo, pelos artigos jurídicos publicados tanto em revistas técnicas quanto em obras coletivas, agora, aos poucos, este princípio começa a figurar também como objeto de estudo abordado por obras monográficas, com pesquisas bastante alongadas. A dissertação de mestrado de Daniel Wunder HACHEM, publicada como "Princípio constitucional da supremacia do interesse público" ${ }^{255}$ em 2011, bem como o livro "Fundamentos da supremacia do interesse público", ${ }^{256}$ publicado no ano de 2012, por João Josué Walmor de MENDONÇA são exemplos claros desta necessidade de aprofundamento acerca das questões suscitadas por este debate, que talvez seja, ainda hoje, o mais instigante a movimentar as ideias acadêmicas pelas mesas de direito administrativo em todo o Brasil.

\subsection{As três dimensões de análise propostas para o estudo do debate}

O debate travado pela doutrina administrativista brasileira quanto ao princípio da supremacia do interesse público sobre o particular tem sua importância repercutida também no âmbito do ensino jurídico propriamente dito, pelo menos, em relação aos temas que atualmente costumam ser discutidos em sede de pós-graduação. O exemplo que se apresenta neste sentido leva por base uma das aulas da disciplina "Consensualidade na Administração Pública", ministrada por Floriano Peixoto de Azevedo MARQUES NETO para o programa de pós-graduação da Faculdade de Direito da Universidade de São Paulo, no segundo semestre de 2011; ocasião em que o professor dividira o referido debate em três planos básicos: no primeiro plano estaria o questionamento da validade da supremacia do interesse público enquanto princípio; no segundo plano estaria o questionamento da validade da supremacia do interesse público enquanto eixo ainda estruturante do direito administrativo; e no terceiro plano estaria um problema de ordem epistemológica, no sentido de se estabelecer um significado uniforme para o termo "interesse público".

\footnotetext{
${ }^{255}$ Daniel Wunder HACHEM. Princípio constitucional da supremacia do interesse público. Belo Horizonte: Fórum. 2011.

${ }^{256}$ João Josué Walmor de MENDONÇA. Fundamentos da supremacia do interesse público. Porto Alegre: Núria Fabris. 2012.
} 
Saindo da sala de aula, o exemplo da classificação metodológica elaborada por Floriano Peixoto de Azevedo MARQUES NETO serve a esta pesquisa, neste momento, para demonstrar que do ponto de vista didático, a melhor forma de abordar o debate doutrinário acerca do princípio da supremacia do interesse público sobre o particular no direito administrativo brasileiro é com o seu desmembramento em três blocos de observação. Tanto é assim que a classificação tripartite também parece organizar o pensamento de Daniel Wunder HACHEM, dada a sistematização, exposta em sua pesquisa sobre o tema, dos questionamentos formulados pela doutrina em relação a este princípio, a partir de três eixos, a saber: 1) a pretensa impossibilidade de enquadramento da supremacia do interesse público na categoria normativa de "princípio"; 2) a suposta inutilidade prática deste princípio; e 3) o alegado perigo de legitimação de práticas autoritárias. ${ }^{257}$

Nas páginas seguintes, o presente estudo desenvolve uma linha de investigação semelhante a estas duas acima apresentadas, vez que, por aqui, o debate em tela também resta analisado de maneira tripartida. Consoante a tudo o que fora explicado no primeiro capítulo, pois, considera-se que todas as discussões referentes ao princípio da supremacia do interesse público sobre o particular no direito administrativo brasileiro abarcam problemas que consistem em divergências teóricas, situadas no sistema jurídico, especificamente, em uma de suas instâncias comunicacionais internas, a dogmática jurídica, que como também já demonstrado, é desenvolvida cientificamente, sobretudo, por meio das pesquisas e das discussões acadêmicas, que são realizadas pelos doutrinadores, isto é, pelas pessoas que se dedicam ao estudo da matéria.

São trabalhadas, portanto, três dimensões teóricas para a análise do debate doutrinário acerca do princípio da supremacia do interesse público sobre o particular no direito administrativo brasileiro.

A primeira dimensão de análise do debate aborda as divergências teóricas que dividem os doutrinadores administrativistas quanto à noção jurídica de interesse público, num sentido correspondente ao do problema epistemológico acima mencionado, com apoio na classificação de Floriano Peixoto de Azevedo MARQUES NETO. Trata-se, em suma, da questão preponderantemente conceitual do debate.

${ }^{257}$ Cf. Daniel Wunder HACHEM. Princípio constitucional da supremacia do interesse público. p. 217. 
Dilemas conceituais, no entanto, também são examinados na segunda dimensão de análise do debate, que trata das divergências teóricas acerca do caráter principiológico da supremacia do interesse público sobre o particular. Nesta dimensão, a principal questão a ser investigada é a da compatibilidade ou incompatibilidade da palavra supremacia com o conceito de princípio jurídico, nos termos discutidos pela doutrina nos dias atuais.

E por fim, a terceira dimensão de análise do debate navega pelas divergências teóricas que envolvem a concepção de centralidade do princípio da supremacia do interesse público sobre o particular no ordenamento jurídico brasileiro, principalmente no que diz respeito a sua conformidade ou oposição ao princípio da dignidade da pessoa humana e, por conseguinte, aos direitos fundamentais do homem e a teleologia da constituição federal de 1988. 
SEGUNDA PARTE: DA INVESTIGAÇÃO DO OBJETO 


\section{PRIMEIRA DIMENSÃO DE ANÁLISE DO DEBATE: AS DIVERGÊNCIAS TEÓRICAS ACERCA DA NOÇÃO JURÍDICA DE INTERESSE PÚBLICO}

\subsection{Um contraste de perspectivas doutrinárias}

Emprestando os dizeres de Celso Antônio BANDEIRA de MELLO, "[n]inguém duvida da importância da noção jurídica de "interesse público"”. ${ }^{258}$ Afinal, caso assim não fosse, o próprio debate que ora se investiga não existiria ou, mesmo existindo, desprovido estaria de qualquer sentido dogmático e, consequentemente, da polêmica e volumosa repercussão doutrinária que, em verdade, possui.

A relevância desta noção jurídica para o direito administrativo é, com efeito, proporcional ao grau de sua complexidade conceitual. ${ }^{259}$ Deste modo, a polêmica entre os doutrinadores administrativistas decorre de uma situação também explanada por Celso Antônio BANDEIRA de MELLO: “[s]em embargo, não se trata de uma noção tão simples que se imponha naturalmente, como algo de per si evidente, que dispensaria qualquer esforço para gizar-lhe os contornos abstratos". 260

Referidos "esforços para gizar os contornos abstratos da noção jurídica de interesse público" revelam, obviamente, a existência de dificuldades conceituais que circundam o tema e, por este plano, alimentam o debate doutrinário, pois, não se pode ignorar que, na lógica jurídica, a ausência dos “contornos abstratos” torna qualquer noção jurídica inservível no caso concreto.

Como assinala Odete MEDAUAR, “[m]esmo sem exaurir todos os modos de conceituar interesse público, logo se conclui no sentido da impossibilidade de chegar a

\footnotetext{
${ }^{258}$ Celso Antônio BANDEIRA de MELLO. A noção jurídica de "interesse público". in Celso Antônio BANDEIRA de MELLO. Grandes temas de direito administrativo. p.181.

259 Neste sentido, colaciona-se o pensamento de Odete MEDAUAR: "[a] presença ampla da expressão interesse público no âmbito do direito administrativo contrasta, no entanto, com as dificuldades que surgem ao se tentar apreensão terminológica ou conceitual, dotada de alguma precisão". in Odete MEDAUAR. $O$ direito administrativo em evolução. p. 186.

${ }^{260}$ Celso Antônio BANDEIRA de MELLO. A noção jurídica de "interesse público". in Celso Antônio BANDEIRA de MELLO. Grandes temas de direito administrativo. p.181.
} 
uma definição jurídica precisa; tal noção não corresponde a uma realidade direta e univocamente definível". ${ }^{261}$

De maneira surpreendente, entretanto, essa percepção foi tratada com palavras de romantismo na doutrina estrangeira, segundo a lição, em certa ocasião, ${ }^{262}$ de Guillermo Andrés MUÑOZ:

\begin{abstract}
"Um pouco do que ocorre com o interesse público se passa com o amor: quem não se anima a dizer que sentiu, que conhece o que é o amor, que suas veias latiram através do amor, que o ritmo de seu pulso se moveu através dessa coisa ancestral que é o amor? Sem embargo, quando se quer definir o amor, é como se desaparecesse, como se perdesse força, como se se perdesse todo. Então, é melhor não defini$10 " .{ }^{263}$
\end{abstract}

O relato do doutrinador argentino é útil para a compreensão da razão discordante dos argumentos que se chocam dentro desta dimensão de análise do debate doutrinário acerca do princípio da supremacia do interesse público sobre o particular no direito administrativo brasileiro. Isto porque as dificuldades conceituais - e aqui, incluem-se tanto as manifestações doutrinárias críticas quanto as defensivas - que envolvem a noção jurídica de interesse público podem ser entendidas, basicamente, de duas formas opostas, a depender de como o fenômeno jurídico-administrativo é concebido pelo jurista que a discute. $^{264}$

\footnotetext{
${ }^{261}$ Odete MEDAUAR. O direito administrativo em evolução. p. 188. No mesmo sentido, Floriano Peixoto de Azevedo MARQUES NETO. Regulação estatal e interesses públicos. p. 83. Ao que parece, ambos acolhem o entendimento de Alessandro PIZZORUSSO. Interesse pubblico e interesse publici. in Rivista Trimestrale di Diritto e Procedura Civile. p.68.

${ }^{262}$ Neste ponto, a referência se dá em relação à conferência inaugural do $V$ Congreso de La Asociación de Derecho Público del MERCOSUR, proferida em 28 de maio de 2003. Cf. Guillermo Andrés MUÑOZ. El interes público es como el amor. in Romeu Felipe BACELLAR FILHO; Daniel Wunder HACHEM (coord.). Direito administrativo e interesse público: estudos em homenagem ao professor Celso Antônio Bandeira de Mello. p. 21-31.

${ }^{263}$ Tradução livre. No original: "Um poco con el interés público, pasa como com el amor: quién no se anima a decir que ha sentido que conoce lo que es el amor, que sus venas han latido a través del amor, que el ritmo de su pulso se há movido a través de esa cosa ancestral que es el amor? Sin embargo cuando al amor se ló quiere definir, es como si desapareciera, como si perdiera fuerzas, como si perdiera todo. Entonces, es mejor no definirlo". in Guillermo Andrés MUÑOZ. El interes público es como el amor. in Romeu Felipe BACELLAR FILHO; Daniel Wunder HACHEM (coord.). Direito administrativo e interesse público: estudos em homenagem ao professor Celso Antônio Bandeira de Mello. p. 30.

${ }^{264}$ De acordo com os ensinamentos de Eros Roberto GRAU: "[p]odemos descrever o direito de várias formas e desde várias perspectivas; na verdade, contudo, não descrevemos jamais a realidade, porém o nosso modo
} 
Por outras palavras, o que aqui se identifica é um contraste de perspectivas doutrinárias, cabendo, pois, indagar: neste ponto, sobre o que realmente divergem os doutrinadores? Em suma, de um lado, alguns autores podem refutar o princípio em tela em razão da "indeterminabilidade abstrata" 265 inerente à noção jurídica que o substancia, a noção de interesse público, aduzindo a inviabilidade de sua aplicação objetiva; de outro, autores discordantes podem defender a mesma característica e sustentá-la como qualidade flexível e fluída, própria para a concreção do agir administrativo.

Como não poderia deixar de ser, no primeiro caso, caracteriza-se uma perspectiva negativa; no segundo, uma perspectiva positiva. ${ }^{266}$ Essa dualidade, de grande relevância para esta dimensão do debate, restará esclarecida no tópico seguinte, com o cotejo das posições doutrinárias de maior repercussão no âmbito do direito administrativo brasileiro, atinentes à questão ora analisada.

\subsection{Duas formas de enxergar a indeterminação conceitual da noção jurídica de interesse público, segundo a doutrina administrativista brasileira}

Para Humberto Bergmann ÁVILA, a noção jurídica de interesse público expressa um conteúdo não só indeterminável, quando considerado no contexto do princípio em

de ver a realidade. (...) Logo, ao afirmar que podemos descrever o direito (note-se bem que me refiro, aqui, a direito como objeto em nível de abstração) de várias formas e desde várias perspectivas, estou a dizer que o direito se manifesta, para nós, de várias formas e desde várias perspectivas. E, também, que não descrevemos o direito, porém os nossos modos de ver o direito. in Eros Roberto GRAU. O direito posto e o direito pressuposto. p. 17-18.

265 A expressão é de Humberto Bergmann ÁVILA. in Humberto Bergmann ÁVILA. Repensando o "princípio da supremacia,do interesse público sobre o particular”. in Daniel SARMENTO (org.). Interesses públicos versus interesses privados:desconstruindo o princípio da supremacia do interesse público. p. 189.

${ }^{266}$ Respeitando, por óbvio, as diferenças naturalmente encontradas nas abordagens de cada autor sobre este tema, vale consignar que identifico como "perspectivas doutrinárias negativa e positiva" a mesma divisão de argumentos classificada como "tese e antítese" por Carlos Vinícius Alves RIBEIRO. in Carlos Vinícius Alves RIBEIRO. Interesse público: um conceito jurídico determinável. in. Maria Sylvia Zanella DI PIETRO e Carlos Vinícius Alves RIBEIRO (coord.). Supremacia do interesse público e outros temas relevantes do direito administrativo. p. 103-119.; e como "sofismas e verdades" por José dos Santos CARVALHO FILHO. In José dos Santos CARVALHO FILHO. Interesse público: verdades e sofismas. in. Maria Sylvia Zanella DI PIETRO e Carlos Vinícius Alves RIBEIRO (coord.). Supremacia do interesse público e outros temas relevantes do direito administrativo. p. 67-84. 
debate, como inconciliável com os interesses privados. ${ }^{267} \mathrm{O}$ posicionamento do autor tem a acolhida de Patrícia BAPTISTA, para quem "[a] identificação do interesse da Administração com o interesse público e a frequente obscuridade na determinação do que seja o interesse público são alguns dos problemas que dificultam a aceitação incondicional de tal dogma no direito administrativo contemporâneo". ${ }^{268}$ Em tom ainda mais crítico e potencialmente radical, Daniel SARMENTO brada “(...) a absoluta indeterminação do conceito de interesse público, em profunda crise $^{269}$ no contexto de fragmentação e pluralismo que caracteriza as sociedades contemporâneas"; 270 sua preocupação vai no sentido de que “(...) a profunda indeterminação semântica do conceito pode permitir às autoridades públicas que o manuseiam as mais perigosas malversações". ${ }^{271}$ A crítica é similar a de Alexandre Santos de ARAGÃO ao asseverar que "em uma sociedade complexa e pluralista não há apenas um interesse público, mas muitos"272; e ao cabo, alinhada com o pensamento de André Ramos TAVARES e Fabrício BOLZAN, quando

${ }^{267}$ Cf. Humberto Bergmann ÁVILA. Repensando o "principio da supremacia,do interesse público sobre o particular". in Daniel SARMENTO (org.). Interesses públicos versus interesses privados:desconstruindo o princípio da supremacia do interesse público. p. 189-190.

${ }^{268}$ Patrícia BAPTISTA. Transformações do direito administrativo. p. 184

${ }^{269}$ Para os fins de um debate científico, a palavra "crise" é, também, de certo modo problemática, já que suscetível de ser utilizada de diversas maneiras e em diversos contextos, com ou sem precisão conceitual. Contudo, acerca da matéria presente, ou seja, da noção jurídica de interesse público, uma boa explicação sobre o que pode ser entendido por "crise(s)" e como ela(s) pode(m) ser analisada(s) - independentemente de se concordar ou não com a sua posição - é encontrada em Floriano Peixoto de Azevedo MARQUES NETO, em trecho que, embora extenso, importa ser transcrito: "A noção de interesse público vive, na verdade, duas crises: uma endógena e outra exógena. A primeira foi por nós abordada (...), quando analisamos a questão da interpretação e aplicação do interesse público e dissemos que a noção, de início diretamente vinculada ao princípio da legalidade (que identificava o interesse público com a expressa locução legal), se esgarça a partir da crescente necessidade de interpretação ou preenchimento da feição aberta que vai assumindo a legalidade a partir da emergência do Estado Intervencionista. Com o crescimento da margem de atuação do aparato burocrático inicia-se um certo esgarçamento da centralidade e da uniformidade de interesse público. Chegase, assim, à crise dos pressupostos de calculabilidade e de certeza jurídica que subjazem à racionalidade do Direito Moderno. A esta crise acrescenta-se, mais recentemente, outra, que poderíamos chamar de exógena, porquanto imposta por fatores externos à Administração Pública e ao Direito Administrativo, embora não independentes da crise endógena. Trata-se do colapso do conceito a partir dos processos que afetam a centralidade e a delimitação (confinamento) do poder decisório estatal. Fruto da internacionalização da economia e da fragmentação social (...), tais processos abalam inclusive os pressupostos de legitimação do poder político, incluindo, obviamente, a noção de interesse público." in Floriano Peixoto de Azevedo MARQUES NETO. Regulação estatal e interesses públicos. p. 144-145.

${ }^{270}$ Daniel SARMENTO. Interesses públicos vs. interesses privados na perspectiva da teoria e da filosofia constitucional. in Daniel SARMENTO (org.). Interesses públicos versus interesses privados:desconstruindo o princípio da supremacia do interesse público. p. 27.

${ }^{271}$ Daniel SARMENTO. Interesses públicos vs. interesses privados na perspectiva da teoria e da filosofia constitucional. in Daniel SARMENTO (org.). Interesses públicos versus interesses privados:desconstruindo o princípio da supremacia do interesse público. p. 27.

272 Alexandre Santos de ARAGÃO. A “supremacia,do interesse público" no advento do Estado de Direito e na hermenêutica do direito público contemporâneo. in Daniel SARMENTO (org.). Interesses públicos versus interesses privados:desconstruindo o princípio da supremacia do interesse público. p. 6. 
juntos apontam que "[a] multidimensionalidade dos direitos (entre individuais, coletivos e sociais) demonstra exatamente essa inviabilidade conceitual". 273

De outra banda, por outros doutrinadores, aludidas características não são vistas como “inviabilidades conceituais". Neste sentido, Daniel Wunder HACHEM lembra que a existência de uma multiplicidade de interesses públicos nunca foi questionada pela doutrina que acolhe o princípio em debate. ${ }^{274} \mathrm{E}$ de fato encontra-se, por exemplo, nos escritos de Maria Sylvia Zanella DI PIETRO, o aviso de que "[e]m um Estado que adota, a partir do preâmbulo da Constituição, a ideia de uma sociedade pluralista, está afirmada a existência de diversidade de opiniões, de ideais, de culturas, de religião, de classes sociais, cada qual com seus próprios interesses". ${ }^{275}$ Isso não seria, portanto, um empecilho de conceituação, já que no entender de Marçal JUSTEN FILHO, “[a] indeterminação não é um defeito do conceito, mas um atributo destinado a permitir sua aplicação mais adequada caso a caso", 276 propiciando "(...) a aproximação do sistema normativo à riqueza do mundo real”. ${ }^{277}$ Desta feita, pelo entendimento de Carlos Vinícius Alves RIBEIRO, “(...) não é pelo fato de a expressão interesse público estar presente em algumas patologias administrativas (desvio de poder), que se deverá sustentar o seu fim". ${ }^{278}$ Ao revés, segundo Emerson GABARDO “(...) essa questão retrata um falso problema, pois o fato de o conceito de interesse público ser vago não retira sua possibilidade de significado"; ${ }^{279}$ logicamente, em conformidade com o ordenamento jurídico.

\footnotetext{
273 André Ramos TAVARES; Fabrício BOLZAN. Poder de polícia:da supremacia do interesse público à primazia dos direitos fundamentais. in Adilson Abreu DALLARI; Carlos Valder do NASCIMENTO; Ives Gandra da Silva MARTINS (coord.). Tratado de direito administrativo, 2. p. 382.

274 Cf. Daniel Wunder HACHEM. Princípio constitucional da supremacia do interesse público. p. 301.

275 Maria Sylvia Zanella DI PIETRO. Discricionariedade administrativa na Constituição de 1988. p.224.

${ }^{276}$ Marçal JUSTEN FILHO. O conceito de interesse público e a "personalização"do direito administrativo. in Revista Trimestral de Direito Público, ed. 26. p. 118.

${ }^{277}$ Marçal JUSTEN FILHO. O conceito de interesse público e a "personalização"do direito administrativo. in Revista Trimestral de Direito Público, ed. 26. p. 118.

${ }^{278}$ Carlos Vinícius Alves RIBEIRO. Interesse público: um conceito jurídico determinável. in. Maria Sylvia Zanella DI PIETRO e Carlos Vinícius Alves RIBEIRO (coord.). Supremacia do interesse público e outros temas relevantes do direito administrativo. p. 103-119.

279 Emerson GABARDO. Interesse público e subsidiariedade. p. 116. É de se notar, apenas para esclarecimento, que os posicionamentos exarados pelos três últimos autores citados - Marçal JUSTEN FILHO, Carlos Vinícius Alves RIBEIRO e Emerson GABARDO - utilizam como base de raciocínio a chamada "teoria dos conceitos jurídicos indeterminados", muito utilizada no âmbito do direito administrativo, por guardar íntima relação com a importante e sempre controvertida questão da discricionariedade administrativa. A propósito de uma visão geral sobre o tema, com uma interessante abordagem sobre as contribuições do direito estrangeiro para o estudo da matéria, ver, sem prejuízo de outros
} 
A conjugação de todos os posicionamentos acima relacionados acaba por formatar um significativo núcleo de divergência teórica, porquanto referente ao aspecto conceitual da noção jurídica estruturante do princípio da supremacia do interesse público sobre o particular. Todavia, para uma melhor análise acerca das razões embutidas em cada manifestação doutrinária, impõe-se conhecer as linhas de pensamento que dão suporte para a motivação de qualquer posição assumida. Este é o objetivo do tópico abaixo.

\subsection{Linhas de pensamento importantes para a discussão em torno da noção jurídica de interesse público: a tônica da bipartição conceitual}

Mais importante que estar ciente das opiniões que se chocam e tensionam o debate doutrinário acerca da supremacia do interesse público sobre o particular no direito administrativo brasileiro, na especificidade da dimensão ora explorada, talvez seja investigar algumas contribuições teóricas que certamente orientam - ou, pelo menos, deveriam orientar ${ }^{280}$ - os estudos de todos os debatedores.

Neste sentido, são consideradas "contribuições teóricas" os elementos já produzidos pela doutrina - com a apreciação das linhas de pensamento propostas pelos autores estrangeiros, inclusive - para a classificação e delimitação conceitual da noção jurídica de interesse público. ${ }^{281}$

Também, em sintonia com a já invocada lição de Miguel REALE, essas contribuições podem ser classificadas como construções doutrinárias apresentadas como esquemas teóricos reciprocamente correlacionados para a composição sistemática dos fundamentos de direito. ${ }^{282}$

trabalhos igualmente importantes, Dinorá Adelaide Musetti GROTTI. Conceitos jurídicos indeterminados e discricionariedade administrativa. in Cadernos de direito constitucional e ciência política, $\mathrm{n}^{\circ}$. 12. p. 84-115.

${ }^{280}$ A premissa que se busca obedecer é a do conhecimento teórico como pressuposto de qualquer debate acadêmico. Sendo mais direto e possivelmente óbvio: para que alguém possa se posicionar adequadamente dentro de um debate, é preciso que esse alguém conheça, senão todas, pelo menos, boa parte das teorias já existentes sobre o assunto debatido. Neste sentido, ver: Romeu Felipe BACELLAR FILHO. A noção jurídica de interesse público no direito administrativo brasileiro. in Romeu Felipe BACELLAR FILHO; Daniel Wunder HACHEM (coord.). Direito administrativo e interesse público: estudos em homenagem ao professor Celso Antônio Bandeira de Mello. p. 89-90.

${ }^{281}$ Cf. Floriano Peixoto de Azevedo MARQUES NETO. Regulação estatal e interesses públicos. p. 85.

${ }^{282}$ Consultar, no segundo capítulo desta pesquisa, o tópico 2.1. retro. 
Um primeiro exemplo de contribuição teórica para o estudo da noção jurídica de interesse público pode ser extraído do direito escandinavo, através do pensamento de Alf Niels Christian ROSS. Para este autor, os interesses públicos estão divididos em interesses sociais e interesses de Estado. Sem embargo, por suas próprias palavras, esta divisão conceitual é explicada da seguinte forma:

\begin{abstract}
"Os interesses públicos, pode-se dizer também, são interesses sociais protegidos pelo Estado como expressão dos órgãos politicamente organizados do poder da comunidade. Assim, os interesses sociais num ordenamento ou regulamentação da propriedade (da paz, do casamento, da defesa do país, etc.) são interesses públicos. A expressão se usa também para designar os interesses específicos individuais derivados detidos pelas autoridades públicas em conexão com a proteção dos interesses públicos no sentido geral . Por exemplo, se as forças armadas, como parte de seu trabalho em prol da defesa nacional, querem instalar uma linha de tiro numa certa área, este interesse individual também é denominado interesse público. Seria, todavia, conveniente, por questões de clareza, reservar a expressão interesse público para os interesses sociais, gerais (em nosso exemplo, a defesa nacional) e chamar os interesses individuais derivados (instalar uma linha de tiro) de interesses de Estado". ${ }^{283}$
\end{abstract}

Note-se que apesar de quase não ser citado pelos doutrinadores brasileiros que tratam do assunto, ${ }^{284}$ a transcrita linha de pensamento de Alf Niels Christian ROSS assemelha-se a outras classificações doutrinárias, notadamente, pela bipartição conceitual efetuada. Outrossim, é possível verificar o recorte binário da noção jurídica de interesse público também em contribuições teóricas de outros autores, entre eles, alguns integrantes da doutrina administrativista portuguesa, como é o caso de Rogério Ehrhardt SOARES, quando, para identificar a noção de interesse público como "elemento decisivo da vinculação administrativa", constrói um raciocínio que esboça distinções entre interesse primário e interesses secundários.

\footnotetext{
283 Alf Niels Christian ROSS. Direito e justiça p. 415-416.

${ }^{284}$ Talvez pelo fato deste autor não ter sido considerado, verdadeiramente, administrativista; eis que suas obras costumam ser mais consultadas no âmbito da filosofia jurídica, da teoria geral do direito e do direito internacional. É preciso registrar, contudo, a exceção à regra, verificada no trabalho de Emerson GABARDO, que examina o pensamento de Alf Niels Christian ROSS, especificamente, em: Emerson GABARDO. Interesse público e subsidiariedade. p. 306-308.
} 
"Trata-se agora de interesses públicos, de interesses que o legislador reconheceu como tendo instrumentalidade imediata para a actualização do bem comum, e a sua definição e tipicização significam ineludivelmente a afirmação da necessidade imperiosa de serem sempre prosseguidos pelo agente que lhes foi proposto.

$(\ldots)$

E por isto é que o legislador não pode permitir que outra vontade se substitua à sua, na realização do interesse público. Ele que reservou para si os juízos sobre o interesse primário e sobre a adequação que lhe deve propor dos interesses secundários, teria abandonado a sua tarefa se, depois disso, fosse admitir que a Administração, com outra vontade que não a dele, viesse a prosseguir esse interesse público.

\section{$(\ldots)$}

O interesse público é, assim, o elemento decisivo da vinculação administrativa". 285

Na passagem acima colacionada, embora não se encontre a palavra "Estado", parece haver uma identificação desta com a noção jurídica de interesse público, evidenciada pela distinção conceitual apresentada, que, também ao que parece, coloca a figura do "Estado-administrador" em posição de submissão em relação a do "Estadolegislador". Em termos didáticos e para efeitos de maior objetividade conceitual, a proposta de Rogério Ehrhardt SOARES torna-se, possivelmente, mais fácil de ser compreendida através da sistematização de Diogo Freitas do AMARAL, outro autor lusitano:

"Segundo Rogério Soares, pode distinguir-se o interesse público primário dos interesses públicos secundários: o interesse público primário é aquele cuja definição e satisfação compete aos órgãos governativos do Estado, no desempenho das funções política e legislativa: é o bem comum nacional; os interesses públicos secundários são aqueles cuja definição é feita pelo legislador, mas cuja satisfação cabe à Administração pública no desempenho da

${ }^{285}$ Rogério Ehrhardt SOARES. Interesse público, legalidade e mérito. p. 118-120. apud Patrícia BAPTISTA. Transformações do direito administrativo. p. 193. 
função administrativa. Exemplos: a segurança pública, a educação, a saúde pública, a cultura, os transportes coletivos, etc". ${ }^{286}$

A bipartição da noção jurídica de interesse público constitui opção metodológica também presente na doutrina italiana, observando-se, pois, nesta matéria, o estudo desenvolvido por Alessandro PIZZORUSSO, cuja primeira conclusão é pela necessidade da distinção entre as locuções interesse público e interesses públicos, justificada nos seguintes termos:

\begin{abstract}
“A primeira conclusão é a confirmação da necessidade de se distinguir interesse público de interesses públicos: estes últimos são as finalidades concretas cuja persecução tendem os atos jurídicos efetivamente realizados no exercício de funções neutras, enquanto o interesse público é o meio lógico-jurídico que permite aos operadores levar em conta tais finalidades, tanto deduzindo via de interpretação teleológica da experiência anterior, quanto as assegurando diretamente, mediante um juízo de valor, a fim de que sejam invocadas dentro dos limites possíveis nas diversas situações e que variam caso a caso.

Em consequência, enquanto os interesses públicos, no plural, são de fato interesses verdadeiros, confrontáveis com os interesses privados, classificáveis do ponto de vista da sua latitude, segundo critérios territoriais, pessoais, materiais, etc. O interesse público, no singular não é um interesse comparável a outros, mas é um instrumento jurídico a que se recorre para fazer valer aqueles interesses concretos que são suscetíveis de serem qualificados como públicos". ${ }^{287}$
\end{abstract}

\footnotetext{
${ }^{286}$ Diogo Freitas do AMARAL. Curso de direito administrativo - com a colaboração de Lino Torgal. Vol. II. p. 36 .

287 Tradução livre. No original: "La prima conclusione è la conferma della necessita di tenere distinto I'interesse pubblico dagli interessi pubblici: questi ultimi sono le finalitá concrete al cui perseguimento tendono gli atti giuridici effetivamente compiuti nell'esercizio di funzioni neutrali, mentre I'interesse pubblico è il mezzo lógico-giuridico che cosente agli operatori di tener conto di siffatte finalità, sia desumendole in via di interpretazione teleologica dall'esperienza anteriore, sia accertandole direttamente mediante um giudizio di valore onde farle valere entro i limiti in cui ciò è possible nelle diverse situazoni e che variano da caso a caso. Di consequenza, mentre gli interessi pubblici, al plurale, sono in effetti veri e propri interessi, confrontabili com gli interessi privati, classificabili dal punto di vista della loro latitudine secondo criteri territoriali, personali, materiali, ecc., I'interesse pubblico, al singolare, non è um interesse paragonabile ad altri, mas è uno strumento giuridico cui si ricorre per far valere quegli interessi concreti che si ritenga di peter qualificare come pubblici.". in Alessandro PIZZORUSSO. Interesse pubblico e interessi.pubblici.in Rivista Trimestrale di Diritto e Procedura Civile. p. 85.
} 
Por essa esteira, outro modelo dicotômico importante é o defendido por Massimo Severo GIANNINI. Neste modelo, os interesses públicos estão classificados em duas categorias, a saber: gerais e setoriais.

\begin{abstract}
"Interesse público não significa interesse objetivamente próprio da generalidade, exceto em um número limitado de eventualidades. Se distinguem em interesses públicos gerais (por exemplo: a segurança externa, a educação pública, a política externa) e setoriais (por exemplo: administrações da marinha mercante, da indústria, do comércio com países estrangeiros, etc.) Os interesses setoriais são aqueles virtualmente conflitantes, dos quais foram ditos no $\S$ anterior, em específico, são interesses setoriais aqueles que possuem como portadores os públicos menores". ${ }^{288}$
\end{abstract}

Como bem observa Roberto Rangel MARCONDES, os interesses públicos setoriais, expressos por Massimo Severo GIANNINI, às vezes se confundem com os interesses difusos; outras, com os interesses coletivos. ${ }^{289}$ Esta observação mostra-se oportuna para que não se deixe de fazer menção, sobretudo pelo peso de sua relevância e utilidade dogmáticas, à contribuição teórica trazida pelos doutrinadores processualistas.

As teorias acerca da dicotomia entre interesses difusos e interesses coletivos, binômio marcante no estudo do direito processual, também andam longe do consenso doutrinário. $^{290}$ Um sentido de abordagem possível e aproximado, a modo geral, da concepção administrativista, separa as noções ora destacadas pelo critério da chamada

\footnotetext{
${ }^{288}$ Tradução livre. No original: "Interesse pubblico non significa interesse oggetivamente próprio della generalità, se non in um limitato numero di evenienze. Si distinguno gli interessi pubblici in generali (p. es.: sicurezza esterna, istruzione pubblica, posizione Internazionale della collettività), e settoriali (p. es.: amministrazioni della marina mercantile, dell'industria, del commercio com l'estero, ecc.) Gli interessi settoriali sono quelli virtualmente confliggenti, di cui si è detto al § prec.; in particolare sono interessi setorialli quelli che hanno come portatori enti pubblici minori”. in Massimo Severo GIANNINI. Diritto amministrativo. p. 113-114.

${ }^{289}$ Não obstante, e isso também é observado por Roberto Rangel MARCONDES, os interesses públicos setoriais se distinguem dos interesses coletivos "stricto sensu" em virtude de sua maior generalidade. $\mathrm{O}$ autor comenta, com base nos exemplos apresentados pelo próprio Massimo Severo GIANNINI: "O interesse pelo desenvolvimento da marinha mercante pode envolver um grande número de pessoas e empresas, não se podendo delimitar em apenas um grupo ou categoria de pessoas, isto é, os sujeitos ligados ao bem não são determináveis (quem pode se beneficiar com o desenvolvimento da marinha mercante? A indústria naval, os investidores da bolsa de valores, os trabalhadores, etc.)". in Roberto Rangel MARCONDES. A importância da participação popular na definição do interesse público a ser tutelado pelo Ministério Público do Trabalho. p. 73.

${ }^{290}$ Para Ada Pellegrini GRINOVER, aliás, esta seria, na realidade, uma divisão tripla, já que em sua classificação, interesses difusos e interesses coletivos, juntamente com os interesses públicos constituem espécies do gênero interesses metaindividuais. Cf. Ada Pellegrini GRINOVER. A problemática dos interesses difusos. in Ada Pellegrini GRINOVER (coord.). A tutela dos interesses difusos. p. 29-31.
} 
relação-base. De acordo com a lição de José Augusto DELGADO, seria “(...) difuso o interesse que abrange número indeterminado de pessoas unidas pelo mesmo fato, enquanto interesses coletivos seriam aqueles pertencentes a grupos ou categorias de pessoas determináveis, possuindo uma só base jurídica". ${ }^{291}$ Com efeito, os dois lados do binômio restariam albergados pela noção jurídica de interesse público, conforme sustenta Maria Sylvia Zanella DI PIETRO:

"Embora se faça essa distinção entre interesse coletivo e interesse difuso, constituem, ambos, modalidades de interesse público, já que em todas as hipóteses configuradas trata-se de interesse emergente da vida em comunidade, que nem sempre corresponde à soma dos interesses individuais, mas no qual a maioria dos indivíduos reconhece um interesse próprio e direto". ${ }^{292}$

Frise-se que o manejo da locução interesses difusos não é exclusividade da doutrina processualista. Sob uma acepção sociológica, por exemplo, à luz do pensamento de Norbert REICH, ela é mencionada, em conflito pela "alocação e distribuição da riqueza econômica e recursos" ${ }^{, 293}$ com outra ordem de interesses, os chamados interesses especiais. Potencialmente, essa dicotomia também é consubstanciadora da noção jurídica de interesse público. Pelas palavras do autor, a oposição entre interesses especiais e interesses difusos segue abaixo explanada:

\footnotetext{
"Mais importante é a contradição entre "interesses especiais" e "interesses difusos". Os interesses especiais são evidenciados por atores sociais que estão bem organizados devido ao fato de que podem ganhar (ou perder) muito com a mudança social. Os interesses difusos são aqueles que têm o caráter de bem público. Eles dizem respeito à qualidade de vida global. Padrões protetivos mais altos serão proveitosos para todos, como em questões ambientais, de saúde ou dos consumidores, ou ao menos para amplos e definidos grupos, como trabalhadores desempregados em questões trabalhistas ou mulheres na legislação de direitos civis". ${ }^{294}$
}

\footnotetext{
${ }^{291}$ José Augusto DELGADO. Interesses difusos e coletivos: evolução conceitual - doutrina e jurisprudência do STF. in Revista Jurídica, n. ${ }^{\circ} 260$. p. 21. Em sentido convergente, ver Rodolfo de Camargo MANCUSO. Interesses difusos. Conceito e legitimação para agir. p. 77.

${ }^{292}$ Maria Sylvia Zanella DI PIETRO. Discricionariedade administrativa na Constituição de 1988. p. 167.

293 Norbert REICH. Intervenção do Estado na economia (reflexões sobre a pós-modernidade na teoria jurídica). in Revista de Direito Público, n. ${ }^{\circ}$ 94. p. 276.

${ }^{294}$ Norbert REICH. Intervenção do Estado na economia (reflexões sobre a pós-modernidade na teoria jurídica). in Revista de Direito Público, n. ${ }^{\circ} 94$. p. 276.
} 
No Brasil, essa contribuição teórica é acolhida por Floriano Peixoto de Azevedo MARQUES NETO que, sobre ela, assim, discorre:

"No nosso ponto de vista, a classificação de Reich é extremamente feliz. Entendemos que, hoje, ambas as classes de interesses transindividuais (especiais e difusos) devem ser entendidas como interesses públicos.

Os interesses especiais, na medida em que se revelem legitimados perante uma parcela da sociedade e encontrem eco nos princípios estruturantes do ordenamento jurídico, não podem ser desconsiderados como interesses públicos. A partir do momento em que se revelem transcendentes aos interesses particularísticos dos atores sociais organizados, que os encampam, tais interesses públicos consideráveis, devendo ser tomados em conta no processo decisório voltado à alocação de bens, direitos e oportunidades amealhados pela coletividade. Neste particular, parece-nos que a Administração Pública se revela necessária na mediação entre os interesses especiais. Será, porém, nos interesses difusos que mais relevante se põe o exercício do poder político. Efetivamente, na tutela desta classe de interesses públicos é que reside a principal razão de ser do poder político numa perspectiva hodierna. A principal parcela de interesses públicos que demanda a atuação efetiva do poder político cinge-se à tutela dos interesses difusos dotados de hipossuficiência.

Dito de outro modo, a permanência do Estado é imprescindível justamente para assegurar o não-aniquilamento dos interesses dos indivíduos excluídos dos grupos de interesse ou ainda aqueles interesses que não encontrem respaldo em algum interesse especial de que trata Reich". 295

Adentrando ao campo das contribuições teóricas desenvolvidas no âmbito doutrinário nacional, a tônica da bipartição conceitual persiste. No estudo elaborado por Carlos Ari SUNDFELD, a noção jurídica de interesse público é descrita a partir de uma relação de valores, na qual um desses, prevalecente, recebe o nome de interesse público em sentido forte, enquanto o outro, cedente, é chamado de interesse público em sentido mínimo, conforme a seguir exposto:

\footnotetext{
${ }^{295}$ Floriano Peixoto de Azevedo MARQUES NETO. Regulação estatal e interesses públicos. p. 160-162.
} 
"Quando o direito atribui ao Estado o dever de cuidar de certo valor, está implicitamente definindo-o como interesse público, que legitima a atuação estatal (interesse público em sentido mínimo). Só que isso não importa necessariamente tomada de posição da ordem jurídica quanto à prevalência desse valor sobre outros, que com ele se choquem, pois algo pode ser sério o bastante para ensejar a atuação do Estado, mas não sê-lo a ponto de justificar o sacrifício de outros bens. Quando o direito consagra essa prevalência, pode-se falar em interesse público em sentido forte. Essa expressão serve para descrever a relação entre dois valores, um que prevalece (o interesse público em sentido forte) e o que se cede (o interesse simples)" ${ }^{296}$

Trata-se, pois, de proposta similar à apresentada por Daniel Wunder HACHEM, autor que utiliza as expressões interesses públicos em sentido amplo e interesses públicos em sentido estrito como valores que divisam a dupla noção jurídica de interesse público, com distinções exaradas nos seguintes aspectos:

\begin{abstract}
"interesse público em sentido amplo: trata-se do interesse público genericamente considerado, que compreende todos os interesses juridicamente protegidos, englobando tanto o interesse da coletividade em si mesma considerada (interesse geral) quanto interesses individuais e coletivos (interesses específicos), quando albergados pelo Direito positivo. Consiste num pressuposto negativo de validade da atuação administrativa, pois proíbe a prática de qualquer ato que contrariar tais interesses, bem como a expedição de um ato com o fito de atender a uma finalidade diversa daquela que o ordenamento jurídico prevê;

interesse público em sentido estrito: cuida-se do interesse da coletividade em si mesma considerada (interesse geral), a ser identificado no caso concreto pela Administração Pública, em razão de uma competência que lhe tenha sido outorgada expressa ou implicitamente pelo ordenamento jurídico. Pode-se manifestar na forma de um conceito legal ou de uma competência discricionária. Consiste num pressuposto positivo de validade da atuação administrativa, eis que o ordenamento jurídico só autorizará a prática do ato quando presente esse interesse público em sentido estrito, hipótese em que estará autorizada a sua prevalência sobre os interesses individuais e coletivos (interesses específicos) também protegidos pelo sistema normativo". ${ }^{297}$
\end{abstract}

${ }^{296}$ Carlos Ari SUNDFELD. Interesse público em sentido mínimo e sentido forte: o problema da vigilância epidemiológica frente aos direitos constitucionais. in Revista Interesse Público, n. ${ }^{\circ} 28$. p. 31.

${ }^{297}$ Daniel Wunder HACHEM. Princípio constitucional da supremacia do interesse público. p. 162. 
Todas as classificações acima colacionadas compartilham a tônica da bipartição conceitual da noção jurídica de interesse público. E, a grosso modo, como se viu, isso acontece de duas formas: ou no intuito de contemplar a coexistência de um de interesse público mais generalizado em contraste com outro, mais individualizado; ou na tentativa de respaldar uma espécie de pragmatismo, manifesto por uma relação entre meios e fins, que considera a autoridade do Estado como meio para a consecução da finalidade pública, traduzida em ações convergentes com os interesses da sociedade.

É preciso registrar - caso não se tenha depreendido isto da leitura de todos os trechos, proposital e diretamente, transcritos - que as distinções teóricas entre uma bipartição conceitual e outra certamente não podem ser desprezadas; elas existem, motivadas por diferenças quanto aos ideais políticos e ideológicos de cada autor, porém não são - e nem podem ser - nutridas fora da essência paradoxal do direito administrativo, razão pela qual todos os seus binômios - Direito público e direito privado, Estado e sociedade, e sobretudo, autoridade e liberdade -, conquanto criticáveis, continuam a marcar o compasso de uma dinâmica teórica fundamentalmente pendular.

Nesta dimensão, o direito administrativo experimenta um paradoxo também no sentido estritamente dogmático. Referidas diferenças teóricas, para além de revelarem inúmeras hipóteses de delimitação conceitual da noção jurídica de interesse público, abrem margem para uma série de possibilidades discursivas, confirmando e até incrementando a complexidade do debate doutrinário acerca do princípio da supremacia do interesse público sobre o particular no direito administrativo brasileiro, uma vez que a diversidade de posições doutrinárias pode, a um só tempo, tanto ser declamada como mola propulsora da evolução do pensamento jurídico-científico, quanto ser reclamada como mais um "ingrediente" a ser acrescido ao já bem "condimentado" problema da decidibilidade, da segurança jurídica e etc - pontos positivo e negativo, respectivamente, deste paradoxo dogmático - .

De todo o abordado, contudo, duas percepções necessitam, para o andamento desta pesquisa, ser preservadas: num primeiro momento - tópicos 4.1. e 4.2. retro destacou-se a oposição de perspectivas doutrinárias na forma de conceber a indeterminação conceitual da noção jurídica de interesse público; agora - no tópico presente -, fora 
demonstrado como esta mesma noção tem sido investigada por diversas linhas de pensamento, ressaltando a peculiaridade de uma característica comum entre elas, a preponderância de uma compreensão bipartida deste conceito jurídico, como objeto de estudo.

Ainda pela trilha das contribuições teóricas, há mais um passo a ser dado. É preciso destrinchar a conexão estabelecida entre uma derradeira linha de pensamento, desenvolvida na Itália, por Renato ALESSI e o modo como essa teoria foi interpretada, na discussão sobre a delimitação da noção jurídica de interesse público no direito administrativo, pelos doutrinadores brasileiros.

Questões potencialmente interessantes podem e serão enfrentadas no próximo tópico.

\subsection{Sobre a teoria de Renato ALESSI: um erro de leitura na doutrina administrativista brasileira? Uma análise necessária sobre a utilização das expressões interesse(s) público(s) primário(s) e interesse(s) público(s) secundário(s) no direito administrativo brasileiro}

Sem prejuízo de todas as contribuições teóricas até aqui apresentadas, os objetivos da presente pesquisa, neste ponto, demandam maior atenção - e por isso, o destaque da abordagem em tópico próprio - à análise da noção jurídica de interesse público através do enfoque sobre a interpretação que a maioria dos estudiosos de direito administrativo no Brasil conferem à classificação conceitual proposta pelo doutrinador italiano Renato ALESSI.

Com vistas para as divergências teóricas desta dimensão do debate, a linha de pensamento entabulada por este autor representa, possivelmente, a contribuição teórica mais importante para o estudo da matéria, por uma simples razão: a de embasar a formulação conceitual de interesse público mais propalada pela doutrina administrativista brasileira. 
Explica-se: formulada na Itália, com base nos ensinamentos dos juristas Francesco CARNELUTTI e Nicola PICARDI, ${ }^{298}$ a teoria de Renato ALESSI fora difundida no Brasil, sobretudo, através da obra de Celso Antônio BANDEIRA de MELLO; ${ }^{299}$ pulverizando-se, a partir deste momento, em meio as lições delineadas por grande parcela dos cursos e manuais administrativistas, ${ }^{300}$ bem como, em fenômeno mais recente, constituindo, pelo menos ao que parece, a única referência comum presente nas obras monográficas exclusivamente destinadas ao estudo do princípio da supremacia do interesse público sobre o particular. ${ }^{301}$

Assim, exsurge, com certa obviedade, que toda esta repercussão seja intensamente refletida no debate doutrinário acerca da supremacia do interesse público sobre o particular no direito administrativo brasileiro, uma vez que, interligadas estão, teoricamente, a concepção de interesse público discutida pelos doutrinadores brasileiros e a concepção de interesse público formulada por Renato ALESSI.

Considerando o acima relatado é que sobrevém, neste debate, a necessidade de uma investigação, portanto, menos preocupada com a teoria, propriamente dita, elaborada por Renato ALESSI e mais comprometida com o entendimento desta formulação conceitual, segundo a interpretação que lhe é dada pelos seus debatedores, os doutrinadores administrativistas brasileiros.

\footnotetext{
${ }^{298}$ Renato ALESSI. Sistema istituzionale del diritto amministrativo italiano. p. 184.

299 Ver, neste sentido, por exemplo: Celso Antônio BANDEIRA de MELLO. Elementos de direito administrativo. p. 22.

${ }^{300}$ Dirley da CUNHA JÚNIOR. Curso de direito administrativo. 6 ed. p. 37.; Diogenes GASPARINI. Direito administrativo. 10 ed. p. 15.; Marçal JUSTEN FILHO. Curso de direito administrativo. 5 ed. p. 66.; entre outros.

301 Embora o princípio da supremacia do interesse público sobre o particular seja objeto de constante polêmica em artigos jurídicos publicados nos últimos anos, debatido em praticamente todas as obras coletivas que recentemente foram colocadas no mercado - Daniel SARMENTO (org.). Interesses públicos versus interesses privados:desconstruindo o princípio da supremacia do interesse público. Rio de Janeiro: Lumen Juris. 2007.; Alexandre Santos de ARAGÃO; Floriano Peixoto de Azevedo MARQUES NETO (coord.). Direito administrativo e seus novos paradigmas. Belo Horizonte: Fórum. 2008.; Maria Sylvia Zanella DI PIETRO e Carlos Vinícius Alves RIBEIRO (coord.). Supremacia do interesse público e outros temas relevantes do direito administrativo. São Paulo: Atlas. 2010.; entre outros -, ainda não existem muitos trabalhos monográficos voltados específica e exclusivamente para o seu estudo. Sem embargo, verifica-se a importância da teoria de Renato ALESSI nesta dimensão do debate, na leitura das obras de: Eunice Ferreira NEQUETE. Fundamentos históricos do princípio da supremacia do interesse público. Dissertação de Mestrado - Porto Alegre: Faculdade de Direito, Universidade Federal do Rio Grande do Sul. 2005.; Daniel Wunder HACHEM. Princípio constitucional da supremacia do interesse público. Belo Horizonte: Fórum. 2011.; João Josué Walmor de MENDONÇA. Fundamentos da supremacia do interesse público. Porto Alegre: Núria Fabris. 2012.
} 
Ocorre que dentro desta proposta, como também notado por Daniel Wunder HACHEM, há de se examinar um possível erro de leitura da doutrina administrativista brasileira, quando credita a Renato ALESSI e, por extensão, a Celso Antônio BANDEIRA de MELLO, a autoria das expressões interesse público primário e interesses públicos secundários, basicamente, para classificar, como espécies do gênero interesse público, o interesse da coletividade e o interesse fazendário, respectivamente, sendo que, na realidade, “(...) nem Alessi, nem Celso Antônio ao reproduzir suas lições aludem a "interesse público primário" ou a "interesse público secundário". O único interesse considerado como público é o "coletivo primário"”. 302

E realmente, na teoria elaborada por Renato ALESSI, as expressões por ele utilizadas são: interesse coletivo primário, para designar aquilo que, de acordo com o seu entendimento, representa o interesse público; e interesses secundários, para denominar os interesses que, também conforme o seu pensar, podem ser titularizados pela Administração Pública, mas se reportam ao direito privado.

Comentada formulação conceitual, nas palavras originariamente escritas por Renato ALESSI - e não segundo o escólio de qualquer autor brasileiro - são colacionadas da obra italiana, nos seguintes termos:

"Agora, tendo presente que o direito privado é, sem dúvida, um
sistema jurídico destinado a tutelar os interesses secundários
(interesses, por assim dizer, subjetivos, que dizem respeito a um
sujeito determinado, e, portanto, interesses em sentido bastante amplo,
patrimoniais) em contraste com o direito público, sistema jurídico
destinado a tutelar aquilo que é de interesse público (interesse coletivo
primário) que, precisamente como tal, não é o interesse de sujeitos
determinados, mas, sim, o interesse de toda a coletividade (conceito
bem distinto do de administração pública, que representa apenas um
dos sujeitos jurídicos determinados dentro da coletividade); tendo
presente, outrossim, que, se a administração se apresenta exatamente
como titular de um distinto e autônomo interesse secundário, mas pela
sua função essencial e fundamental que é a de realizar direta e
imediatamente o interesse público, gerar caso de dúvida (no caso, isto
é, de uma coincidência entre um interesse secundário da entidade
administrativa e um interesse público específico), deve-se presumir,
na ausência de elementos explícitos que levem a uma convicção
distinta, que a administração tem que realizar o interesse público,

${ }^{302}$ Daniel Wunder HACHEM. Princípio constitucional da supremacia do interesse público. p. 158. 
fazendo uso dos meios postos à disposição do direito público e, portanto, não renunciando à sua posição de supremacia no confronto com os particulares". ${ }^{303}$

De igual forma, inexiste, na obra de Celso de Antônio BANDEIRA de MELLO, principal via difusora do pensamento de Renato ALESSI, qualquer vinculação entre as noções de interesse público e interesses secundários. Duas passagens, dentre outras possíveis, são transcritas neste sentido e deixam claro que, também para ele, os chamados interesses secundários não são interesses públicos:

"Também assim melhor se compreenderá a distinção corrente da doutrina italiana entre interesses públicos ou interesses primários que são os interesses da coletividade como um todo e - interesses secundários, que o Estado (pelo só fato de ser sujeito de direitos) poderia ter como qualquer outra pessoa, isto é, independentemente de sua qualidade de servidor de interesses de terceiros: os da coletividade. Poderia, portanto, ter o interesse secundário de resistir ao pagamento de indenizações, ainda que procedentes, ou de denegar pretensões bem fundadas que os administrados lhe fizessem, ou de cobrar tributos e tarifas por valores exagerados. Estaria, por tal modo, defendendo interesses apenas "seus", enquanto pessoa, enquanto entidade animada do propósito de despender o mínimo de recursos e abarrotar-se deles ao máximo. Não estaria, entretanto, atendendo ao interesse público, ao interesse primário, isto é, àquele que a lei aponta como sendo o interesse da coletividade: o da observância de ordem jurídica estabelecida a título de bem curar o interesse de todos.

Por isso os interesses secundários não são atendíveis senão quando coincidirem com interesses primários, únicos que podem ser perseguidos por quem axiomaticamente os encarna e representa. Percebe-se, pois, que a Administração não pode proceder com a

\footnotetext{
303 Tradução livre. No original: “Ora, tenuto presente che il diritto privato è senza dubbio um sistema giuridico diretto alla tutela di interessi secondari (interessi, per cosi dire, soggettivi, ossia pertinenti ad un soggetto determinato, e pertanto interessi, in senso assai lato, patrimoniali) di contro al diritto pubblico, sistema giuridico diretto alla tutela di quello che è l'interessi púbblico (interesse collettivo primário) il quale appunto in quanto tale non è interesse di soggeti determinati, sibbene interesse di tutta quanta la collettività (concetto ben distinto da quello di pubblica amministrazione, la quale rapresenta appunto uno dei soggetti giuridici determinati in seno alla collettivitá): tenuto presente, inoltre, che se l'amministrazione si presenta appunto anche come titolare di um distinto ed autônomo interesse secondario, pure la sua funzione essenziale e fondamentale è quella di dare realizzazione diretta ed immediata all'interesse pubblico, onde nei casi dubbi (nei casi, cioé, di coincidenza tra un interesse secondario del soggetto amministrativo ed um interesse publicco specifico) si deve presumere in difetto di elementi espliciti che inducano ad una diversa convinzione, che l'amministrazione abbia intenso dare diretta realizazione all'interesse pubblico, valendosi pertanto dei mezzi posti a disposizione dal diritto pubblico e pertanto non rinunziando affatto alla sua posizione di supremazia nei confronti dei singoli privati”.in Renato ALESSI. Sistema istituzionale del diritto amministrativo italiano. p. 195.
} 
mesma desenvoltura e liberdade com que agem os particulares, ocupados na defesa das próprias conveniências, sob pena de trair sua missão própria e sua própria razão de existir ". ${ }^{304}$

$(\ldots)$

"Uma vez reconhecido que os interesses públicos correspondem à dimensão pública dos direitos individuais, ou seja, que consistem no plexo dos interesses dos indivíduos enquanto partícipes da Sociedade (entificada juridicamente no Estado), nisto incluído o depósito intertemporal destes mesmos interesses, põe-se a nu a circunstância de que não existe coincidência necessária entre interesse público e interesse do Estado e demais pessoas do Direito Público.

É que, além de subjetivar estes interesses, o Estado, tal como os demais particulares, é, também ele, uma pessoa jurídica, que, pois, existe e convive no universo jurídico em concorrência com todos os demais sujeitos de direito. Assim, independentemente do fato de ser, por definição, encarregado dos interesses públicos, o Estado pode ter, tanto quanto as demais pessoas, interesses que lhe são particulares, individuais, e que, tal como os interesses delas, concebidas em suas meras individualidades, se encarnam no Estado enquanto pessoa. Estes últimos não são interesses públicos, mas interesses individuais do Estado, similares, pois, (sob prisma extra jurídico), aos interesses de qualquer outro sujeito. (...). Esta distinção a que se acaba de aludir, entre interesses públicos propriamente ditos - isto é, interesses primários do Estado - e interesses secundários (que são os últimos a que se aludiu), é de trânsito corrente e moente na doutrina italiana, e a um ponto tal que, hoje, poucos doutrinadores daquele país se ocupam em explicá-los, limitando-se a fazer-lhes menção, como referência a algo óbvio, de conhecimento geral". ${ }^{305}$

Todavia, no cotejo de citações diretas, a hipótese de distorção terminológica desta classificação conceitual, proposta por Renato ALESSI e seguida por Celso Antônio BANDEIRA de MELLO, aparece confirmada textualmente. Verifica-se tal equívoco, por exemplo, na linha de raciocínio apresentada por Cristiano Barroso Soares MAIA:

"Na Itália, após a Segunda Guerra Mundial, Renato Alessi, preocupado com a possibilidade de uso das prerrogativas da

\footnotetext{
${ }^{304}$ Celso Antônio BANDEIRA de MELLO. Elementos de direito administrativo. p. 22.

${ }^{305}$ Celso Antônio BANDEIRA de MELLO. Curso de direito administrativo. 28 ed. p. 65-66.
} 
Administração Pública de maneira abusiva, sistematizou duas ordens de limites à atividade administrativa.

A primeira delas consistiria na autorização à Administração para prática apenas de atos normativos secundários, ou seja, atos que pressupunham uma lei prévia emanada do poder competente (Parlamento). Não poderia, portanto, inovar na ordem jurídica.

A segunda estaria relacionada ao fato de que a administração exerce uma função, o que significa que os poderes (prerrogativas) são concedidos para a realização de um determinado interesse que, na espécie, é o interesse público (coletivo).

A partir daí, influenciado por Carnelutti e Picardi, começa a delinear a clássica distinção entre interesse público primário e secundário. $\mathrm{O}$ primeiro seria "formado do conjunto de interesses individuais prevalentes numa determinada organização jurídica da coletividade", enquanto que o segundo seria concebido como "um interesse do aparato unitariamente considerado".

$\mathrm{O}$ interesse público secundário seria identificado com o que o Estado possui na qualidade de pessoa jurídica, independente de sua obrigação de atendimento de necessidades coletivas. Logo, dele seria exemplo a conduta de despender a menor quantidade possível de recursos, aumentando a receita tributária ao máximo, a fim de dispor de maior patrimônio. O interesse público primário, por sua vez, exigiria que o Poder Público empregasse recursos na medida necessária à eficácia das prestações e não impusesse tributos aos cidadãos além de uma determinada medida". ${ }^{306}$

Ou, ainda, no discurso crítico de André Ramos TAVARES e Fabrício BOLZAN:

"E a preterição da sociedade e da cidadania, em atenção a um interesse abstratamente chamado de público e truculentamente alavancado como supremo, decorre da insuficiência de argumentos da doutrina tradicional, que deixam de equacionar adequadamente esse interesse público primário (da coletividade) de interesse público secundário (da Administração vista como pessoa jurídica), invocando as lições de Renato Alessi, Carnelutti e Picardi”. ${ }^{307}$

${ }^{306}$ Cristiano Soares MAIA. A (im)pertinência do princípio da supremacia do interesse público sobre o particular no contexto do Estado Democrático de Direito. in Fórum Administrativo - Direito Público. n. 103. p. 21-22.

307 André Ramos TAVARES; Fabrício BOLZAN. Poder de polícia:da supremacia do interesse público à primazia dos direitos fundamentais. in Adilson Abreu DALLARI; Carlos Valder do NASCIMENTO; Ives Gandra da Silva MARTINS (coord.). Tratado de direito administrativo, 2. p. 380. 
Insta observar que o erro, também visível em ideias desenvolvidas por alguns outros autores, ${ }^{308}$ não consiste em advogar qualquer tipo de tese calcada nas terminologias de interesse(s) público(s) primário(s) e interesse(s) público(s) secundário(s) - relembre-se, voltando ao tópico precedente, a possibilidade argumentativa que deflui da lição exarada por Diogo Freitas do AMARAL, com lastro na teoria de Rogério Ehrhardt SOARES, por exemplo -; mas, ocorre quando se resolve debater uma construção doutrinária - no caso, a destacada contribuição teórica formulada por Renato ALESSI, tal qual defendida por Celso Antônio BANDEIRA de MELLO - a partir de uma interpretação equivocada que se tem sobre ela.

A incongruência ora observada faz esvaziar grande parte das divergências teóricas travadas pelos doutrinadores nesta dimensão do debate. Com efeito, estas se encontram contaminadas por um vício lógico, eis que, pela lógica, como seria possível validar qualquer tipo de discordância fundada numa visão distorcida daquilo que se está a discordar?

Isto posto, não convém para a presente pesquisa, portanto, buscar racionalidade em posicionamentos doutrinários que debatem a indeterminação/indefinição/dificuldade conceitual dos interesses públicos e ou a pluralidade destes nos dias atuais e etc., tendo como pano de fundo, "uma noção jurídica de interesse público secundário criada por um autor que não acredita que interesses secundários sejam interesses públicos”.

Contudo, a polêmica que gira em torno da noção jurídica de interesse público secundário, uma vez relacionada a interesses que, convencionalmente, parecem dizer respeito não à sociedade, mas, sim, à Administração Pública, pode ser melhor investigada pelo prisma que envolve, numa outra dimensão de análise, o problema da (in)compatibilidade entre a palavra "supremacia" e as noções teóricas de "princípio jurídico".

\footnotetext{
${ }^{308}$ Luís Roberto BARROSO. Prefácio: o Estado contemporâneo, os direitos fundamentais e a redefinição da supremacia do interesse público. in Daniel SARMENTO (org.). Interesses públicos versus interesses privados:desconstruindo o princípio da supremacia do interesse público. p. xiii.; Izabelle de BAPTISTA. $O$ princípio da supremacia do interesse público sobre o privado: uma análise à luz dos direitos fundamentais e do Estado Democrático de Direito. in Fórum Administrativo - Direito Público. n. 130. p. 55-57 e 61.; Hidemberg Alves da FROTA. O princípio da supremacia do interesse público sobre o privado no direito positivo comparado: expressão do interesse geral da sociedade e da soberania popular. in Revista de Direito Administrativo, n. ${ }^{\circ} 239$. p. 48-49.; entre outros.
} 
O mencionado problema, em suma, reveste o fio condutor pelo qual se desenrola a investigação realizada no capítulo a seguir. Neste momento, porém, é preciso perquirir as possíveis convergências de entendimentos doutrinários desta dimensão, já que as suas divergências, pelas razões acima expostas, são circulares e por isso não geram, quando confrontadas, substrato teórico-evolutivo algum.

Neste sentido, embora inexistam consensos textuais gerais, isto é, concordâncias explícitas nos dizeres de todos os autores que tenham manifestado posições divergentes no debate, é possível que, por angulação invertida, partindo da interpretação teleológica ${ }^{309}$ de todas as divergências contrapostas, alguns pontos teóricos, imunes a qualquer discordância doutrinária, sejam revelados.

Por este critério, a propósito, vislumbrou-se, já no tópico 4.2. retro, um primeiro bloco de convergências doutrinárias sobre o assunto, verificado, em primeiro lugar, com a percepção de que a indeterminação conceitual da noção jurídica de interesse público não é ignorada por nenhum doutrinador administrativista brasileiro; e, em segundo lugar, através da constatação de que a mesma noção resta compreendida de forma pluralizada por todos os integrantes do debate doutrinário em tela, já que os autores que defendem o princípio da supremacia do interesse público sobre o particular não rejeitam a pluralidade de interesses públicos descrita e apontada pelos autores que o criticam.

As divergências dos autores sobre estas questões estão, portanto, fundamentalmente entrelaçadas com o contraste de perspectivas doutrinárias relatado no início deste capítulo, pois, não consistem em dizer se a noção jurídica de interesse público comporta um conceito jurídico determinado ou indeterminado; nem se ela corresponde a um fenômeno jurídico unitário ou pluralístico. Por outro olhar, cediço que ninguém da doutrina administrativista nacional refuta a pluralidade e a indeterminação conceitual da noção jurídica de interesse público, essas divergências, na verdade, guardam íntima relação

\footnotetext{
309 Tendo Carlos MAXIMILIANO definido que "[a] Hermenêutica jurídica tem por objeto o estudo e a sistematização dos processos aplicáveis para determinar o sentido e o alcance das expressões do Direito", utilizo a expressão "interpretação teleológica" de acordo com a acepção mais ampla possível, buscando "determinar o sentido e o alcance das expressões do Direito" que não estão na lei, mas nos textos doutrinários ora examinados. Inspiro-me, com efeito, nas seguintes palavras do autor: "[d]eve o intérprete sentir como o próprio autor do trabalho que estuda; imbuir-se das idéias inspiradoras da obra concebida e realizada por outrem. Anatole France diz, no Jardim de Epicuro: "Compreender uma obra-prima é, em suma, criá-la em si mesmo, de novo". Este pensamento é aplicável a qualquer produto do intelecto do homem, isolado este, ou em coletividade; abrange a linguagem em geral; as expressões do Direito, em particular". in Carlos MAXIMILIANO. Hermenêutica e aplicação do direito. p. 1 e 53.
} 
com a definição de tais características como condições que justifiquem a eliminação ou a manutenção do princípio da supremacia do interesse público sobre o particular dentro do direito administrativo brasileiro.

Paralelamente, na busca por algumas linhas de pensamentos basilares e contributivas, intrínsecas ao problema da classificação e delimitação da noção jurídica de interesse público - tópico 4.3. retro -, ressaltou-se, também, a então chamada tônica da bipartição conceitual como peculiaridade notada do ponto de vista metodológico, sinalizando a preponderância, entre as contribuições teóricas abordadas, de uma compreensão bipartida deste conceito jurídico, como objeto de estudo; daí, no tópico presente, o enfrentamento da divisão terminológica mais utilizada pela doutrina administrativista brasileira, discutida com o manejo das expressões interesse público primário e interesse público secundário.

Feita a necessária ressalva de que aludidas expressões nunca consubstanciaram a formulação conceitual sustentada por Renato ALESSI e Celso Antônio BANDEIRA de MELLO, ainda permanece a dúvida acerca do possível ponto teórico imune a qualquer discordância doutrinária quanto à delimitação da noção jurídica de interesse público. A primeira pista de convergência, neste quadrante, está no entendimento comum a todos os doutrinadores administrativistas brasileiros, no sentido de que os interesses secundários fora do mérito concernente ao equívoco terminológico acima examinado, isto é, sejam esses interesses considerados como públicos ou não - só podem ser atendidos quando coincidirem com o atendimento dos chamados interesses públicos primários. Isso sugere, naturalmente, a existência de um consenso doutrinário, também, no sentido de que, conforme expõe Maria Sylvia Zanella DI PIETRO,“(...) embora o vocábulo público seja equívoco, pode-se dizer que, quando utilizado na expressão interesse público, ele se refere aos beneficiários da atividade administrativa e não aos entes que a exercem". 310

Sendo certo que os interesses referidos "aos beneficiários da atividade administrativa e não aos entes que a exercem" não desbordam de nenhuma concepção doutrinária acerca da noção jurídica de interesse público no direito administrativo brasileiro, este constitui o último ponto convergente identificado nesta dimensão de análise.

\footnotetext{
${ }^{310}$ Maria Sylvia Zanella DI PIETRO. Discricionariedade administrativa na Constituição de 1988. p. 163.
} 


\section{SEGUNDA DIMENSÃo DE ANÁliSE DO DEBATE: AS DIVERGÊNCIAS TEÓRICAS ACERCA DO CARÁTER PRINCIPIOLÓGICO DA SUPREMACIA DO INTERESSE PÚBLICO SOBRE O PARTICULAR}

\subsection{A polêmica da palavra supremacia: considerações gerais para a compreensão do problema}

A impossibilidade de precisão conceitual no estudo da noção jurídica de interesse público $^{311}$ jamais prejudicou “(...) a centralidade que tal formulação ocupa no arcabouço teórico do Direito Administrativo". 312

De todas as manifestações doutrinárias que poderiam ser invocadas neste sentido, a mais conhecida talvez seja a utilizada por Héctor Jorge ESCOLA para definir o direito administrativo como sendo o direito do interesse público:

"O interesse público, de tal modo, é a verdadeira razão de ser e a verdadeira explicação do direito administrativo, o seu real fundamento, o que permite superar a afirmação de que o direito administrativo é o direito da administração pública, para substituí-la por outra, a nosso juízo, mais precisa e abrangente, de que o direito administrativo é o direito do interesse público, buscado através da atividade administrativa". ${ }^{313}$

\footnotetext{
311 Sobre esta impossibilidade, consultar, no quarto capítulo desta pesquisa, o tópico 4.1. retro.

312 in Floriano Peixoto de Azevedo MARQUES NETO. Regulação estatal e interesses públicos. p. 81. E para além das palavras ora transcritas, cumpre também colacionar as razões entabuladas pelo autor para demonstrar como, no seu entender, a noção jurídica de interesse público ocupa um "papel central no paradigma do Direito Administrativo": "[é] que, como anota Marie-Pauline Deswarte, o interesse público cumpre para este ramo do Direito o papel de instrumento (elo de concentração), limite (elo de delimitação) e fundamento (elo de legitimação) do poder. Funcionaria como instrumento de efetivação do poder político, pois traduz o caráter absoluto e perpétuo da soberania em supremacia do interesse público que molda as prerrogativas da Administração Pública. De outro lado, serve de elemento de limitação do âmbito de atuação do poder político (e, portanto, de delimitação dos confins entre as esferas pública e privada), na medida em que vincula sua atuação estritamente àquilo que possa ser justificado como necessário no "influxo de uma finalidade cogente". (...). Por fim, pôr-se-ia como elemento de legitimação do poder, pois serve como fundamento (retórico ou efetivo) da existência e da operacionalização do poder político como um todo e do poder político administrativo em particular, constituindo o "sistema ideal de legitimação da autoridade nos países submetidos submetidos ao Liberalismo". in Floriano Peixoto de Azevedo MARQUES NETO. Regulação estatal e interesses públicos. p. 77-78.

${ }^{313}$ Tradução livre. No original: "El interés público, de tal modo, es la verdadera razón de ser y la verdadera explicación del derecho administrativo, su real fundamento, lo que permite superar la afirmación de que el derecho administrativo es el derecho de la administración pública, para reemplazarla por la más exacta y general, a nuestro juicio, de que el derecho administrativo es el derecho del interés público, pretendido a
} 
Sem embargo, ainda para efeitos de ilustração da relevância do interesse público, tal como a sua noção jurídica encontra-se conectada com o direito administrativo, não parece exagerado destacar - já que desenvolvido com o mesmo propósito - o emblemático apanhado de doutrinas estrangeiras pesquisadas por Emerson GABARDO, em companhia de Daniel Wunder HACHEM:

"A noção de interesse público encontra-se intimamente relacionada com o direito administrativo, a ponto de autores como François SaintBonnet afirmarem que "seria possível escrever uma história de interesse público [intérêt general] que seria o fio condutor de uma história do direito administrativo". No mesmo sentido, conclui José Luis Meilán Gil, após ampla digressão sobre os critérios definitórios do Direito Administrativo. Já Guy Clamour arrola diversas expressões metafóricas utilizadas para explicar a relação entre o conceito de interesse público e o Direito Administrativo, tais como "noção-mãe", "espinha dorsal", "alma", "pedra angular da ação pública", "coração do Direito Público, como a autonomia da vontade para o Direito Privado", "alfa e ômega do Direito Administrativo". Trata-se de uma categoria que irradia o conjunto total das instituições do Direito Administrativo".314

Certamente, referidas concepções teóricas advêm do processo histórico segundo qual, conforme discorrido por Maria Sylvia Zanella DI PIETRO, deu-se início ao desenvolvimento do direito público, com a superação do primado do direito civil $^{315}$ - que já durava há séculos - e, consequentemente, com a substituição da “(...) ideia do homem como fim único do direito pelo princípio que hoje serve de fundamento para todo o direito público e que vincula a administração em todas as suas decisões: o de que os interesses públicos têm supremacia sobre os individuais". 316

través de la actividad administrativa”. in Héctor Jorge ESCOLA. El interes público como fundamento del derecho administrativo . p. 236.

${ }^{314}$ Emerson GABARDO; Daniel Wunder HACHEM. O suposto caráter autoritário da supremacia do interesse público e das origens do direito administrativo: uma crítica da crítica. in. Maria Sylvia Zanella DI PIETRO e Carlos Vinícius Alves RIBEIRO (coord.). Supremacia do interesse público e outros temas relevantes do direito administrativo. p. 32-33.

315 Sem prejuízo, sobre o fenômeno da "publicização do direito privado", vista pelos olhos de uma administrativista, consultar: Irene Patrícia NOHARA. Reflexões críticas acerca da tentativa de desconstrução do sentido da supremacia do interesse público no direito administrativo. in. Maria Sylvia Zanella DI PIETRO e Carlos Vinícius Alves RIBEIRO (coord.). Supremacia do interesse público e outros temas relevantes do direito administrativo. p. 128-130.

${ }^{316}$ Maria Sylvia Zanella DI PIETRO. Discricionariedade administrativa na Constituição de 1988. p. 161. 
Nesta toada, importa reconhecer que a "ideia-força" "317 contida na noção jurídica de interesse público manifesta-se, portanto, através da supremacia que este possui quando confrontado com o interesse particular. Pelo menos, aparentemente, é com este didatismo que o princípio da supremacia do interesse público sobre o particular tem sido apresentado a todos - ou quase todos - os estudantes de direito nos bancos escolares de ensino jurídico do Brasil.

No entanto, sabe-se que o princípio em questão não se consolidou na teoria geral do direito administrativo brasileiro como mero critério de hierarquia, servível tão somente para determinar, no ordenamento jurídico, a superioridade de uma ordem de interesses em relação à outra; mas, sobretudo, como vetor metodológico de um sistema jurídico cientificamente autônomo.

Como já visto, dentro deste sistema - ou, pelo menos, no que condiz com esta ideia específica de sistema -, José CRETELLA JR. alçava o princípio da supremacia do interesse público sobre o particular à condição de "matriz suprema orientadora" de qualquer construção publicística - e não apenas do direito administrativo -, da qual todos os outros postulados provinham logicamente dispostos em pontos mais baixos da pirâmide principiológica, e por isso formava, ao lado do princípio da legalidade, a base de sua teoria de regime jurídico de direito público. ${ }^{318}$

Da mesma maneira, na sistemática descrita por Celso Antônio BANDEIRA de MELLO, o princípio da supremacia do interesse público sobre o particular, junto com o princípio da indisponibilidade do interesse público, constituem as chamadas disposições fundamentais que regem e equilibram o regime jurídico-administrativo, sistema coerente e lógico, posto à harmonização do funcionamento de todos os outros princípios jurídicos, segundo as características próprias do direito administrativo. ${ }^{319}$

Já no âmbito do debate doutrinário acerca do princípio da supremacia do interesse público sobre o particular no direito administrativo brasileiro, Elói Martins SENHORAS e Ariane Raquel Almeida de SOUZA CRUZ procuram, com auxílio gráfico, sistematizar os

\footnotetext{
317 Expressão originariamente cunhada por Floriano Peixoto de Azevedo MARQUES NETO. in Floriano Peixoto de Azevedo MARQUES NETO. Regulação estatal e interesses públicos. p. 81

318 Consultar, no segundo capítulo desta pesquisa, o tópico 2.6. retro.

319 Consultar, no segundo capítulo desta pesquisa, o tópico 2.6. retro.
} 
fundamentos jurídicos que, de acordo com o ponto de vista destes autores, explicariam todo o conteúdo do princípio, destrinchado no quadro abaixo:

\begin{tabular}{|c|c|c|}
\hline & $\begin{array}{c}\text { Direção finalística } \\
\text { da Administração } \\
\text { Pública }\end{array}$ & $\begin{array}{l}\text { Nenhuma atividade administrativa pode se divorciar do fim maior } \\
\text { para o qual foi instituída, que é identificado pela persecução do } \\
\text { interesse público. A título de exemplo, a supremacia do interesse } \\
\text { público revela-se nos casos de existência de bens coletivos que } \\
\text { reclamam alocação ou proteção estatal. }\end{array}$ \\
\hline 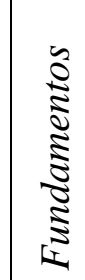 & $\begin{array}{l}\text { Normas que } \\
\text { outorgam } \\
\text { privilégios à } \\
\text { Administração }\end{array}$ & $\begin{array}{l}\text { A superioridade do interesse público em comparação com ao } \\
\text { interesse particular ocorre devido ao embasamento dos princípios } \\
\text { constitucionais regentes da Administração Pública, os quais visam } \\
\text { garantir a estabilidade das relações sociais e a atual estatal nas } \\
\text { lacunas deixadas pelo setor privado. }\end{array}$ \\
\hline & $\begin{array}{l}\text { Ações } \\
\text { administrativas } \\
\text { restritivas de } \\
\text { direitos individuais }\end{array}$ & $\begin{array}{l}\text { Tanto a ordem jurídica infraconstitucional quanto a ordem } \\
\text { constitucional consagram ou refletem o princípio da superioridade } \\
\text { do interesse público sobre o privado. Com efeito, nas normas } \\
\text { jurídicas, muitas vezes, são encontrados os fundamentos para a } \\
\text { restrição de direitos individuais para a garantia de interesses da } \\
\text { coletividade. }^{320}\end{array}$ \\
\hline
\end{tabular}

Como síntese do que acontece nesta dimensão do mencionado debate, todavia, cabe observar que a importância da noção jurídica de interesse público, embora inquestionável para o entendimento de tudo o que envolve o direito administrativo, não é suficiente para afastar, dentro desta disciplina, o dissenso teórico que, em seu limite, rejeitará, por total, a ideia de um princípio denominadamente supremo. $\mathrm{Na}$ dicção de Carlos Ari SUNDFELD, “(...) para a ordem jurídica, o interesse público tem apenas

320 in "Quadro 1 - Supremacia do interesse público no ordenamento jurídico" in Elói Martins SENHORAS; Ariane Raquel Almeida de SOUZA CRUZ. Debates sobre o princípio da supremacia do interesse público sobre o privado. in Repertório de jurisprudência IOB , n. 24 - vol.I. p. 798. 
prioridade em relação ao privado; não é, porém, supremo frente a este. Supremacia é a qualidade do que está acima de tudo". 321

Com maior agudeza e sustentando a tese de que a "[s]upremacia foi a ideia que norteou, e tem norteado ao longo da história, a centralização do Poder, seja em torno de um monarca soberano, ainda que destituído de estado, seja em vista de um Estado absoluto, seja em prol de um regime autoritário, de que espécie for", Eunice Ferreira NEQUETE entende que "[a] terminologia empregada para referir o princípio do interesse público como princípio de supremacia parece incorrer no equívoco de invocar implicitamente a história pregressa de sua construção". ${ }^{322}$

Em balanço do acima exemplificado, é oportuno perceber que tanto os apontamentos de Carlos Ari SUNDFELD quanto os de Eunice Ferreira NEQUETE guardam certa relação argumentativa com as considerações de Humberto Bergmann ÁVILA ao cravar que a teoria jurídica, no caso do princípio da supremacia do interesse público sobre o particular, padece de inadequação semântica. ${ }^{323}$

Essa inadequação semântica, na opinião de Humberto Bergmann ÁVILA, explicaria a "(...) incompatibilidade do "princípio" da supremacia do interesse público sobre o particular com o conceito de princípio jurídico fornecido pela Teoria Geral do Direito"; 324 já que para este autor, sendo direto e objetivo, “(...) o "princípio da supremacia

\footnotetext{
${ }^{321}$ Carlos Ari SUNDFELD. Fundamentos de direito público. p. 154. Note-se que, motivado por idêntico sentido de raciocínio, Fábio Anderson de Freitas PEDRO substitui a palavra "supremacia" pela palavra "primazia". Não parece, entretanto, que uma simples mudança na terminologia empregada para identificar o referido princípio possa solucionar o problema debatido e ora relatado. De qualquer modo, diz o autor: "[o] embate em interesses individuais e interesses públicos em verdade não é resolvido com a imposição inflexível da constituição de um dogma, do axioma da Supremacia. Uma vez que supremo é algo que se impõe a todos os demais sob qualquer circunstância. Em razão da pós-modernidade do direito buscando atender a função social da norma, a tendência é de uma primazia do interesse público sobre o interesse privado a ser mensurado, não só no cotejo da positivação existente, mas em razão de uma ponderação de interesses" in Fábio Anderson de Freitas PEDRO. O sigilo empregado nos processos de investigação de acidentes aéreos no Brasil e a primazia do interesse público. in Revista Forense. vol. 414. p. 551.

${ }^{322}$ Eunice Ferreira NEQUETE. Fundamentos históricos do princípio da supremacia do interesse público. p. 220-221.

${ }^{323}$ Cf. Humberto Bergmann ÁVILA. Repensando o "principio da supremacia,do interesse público sobre o particular". in Daniel SARMENTO (org.). Interesses públicos versus interesses privados:desconstruindo o princípio da supremacia do interesse público. p. 176.

${ }^{324}$ Humberto Bergmann ÁVILA. Repensando o "principio da supremacia,do interesse público sobre o particular". in Daniel SARMENTO (org.). Interesses públicos versus interesses privados:desconstruindo o princípio da supremacia do interesse público. p. 184.
} 
do interesse público sobre o privado" não é, rigorosamente, um princípio jurídico ou norma-princípio". 325

Detalhando o seu ponto de vista, Humberto Bergmann ÁVILA diz:

- "conceitualmente ele [o princípio da supremacia do interesse público sobre o particular] não é uma norma-princípio: ele possui apenas um grau normal de aplicação, sem qualquer referência às possibilidades normativas e concretas;

- normativamente ele não é uma norma-princípio: ele não pode ser descrito como um princípio jurídico-constitucional imamente;

- ele não pode conceitualmente e normativamente descrever uma relação de supremacia: se a discussão é sobre a função administrativa, não pode "o" interesse público (ou os interesses públicos), sob o ângulo da atividade administrativa, ser descrito separadamente dos interesses privados". ${ }^{326}$

Como se pode observar, o autor refuta a adequação conceitual e normativa da supremacia do interesse público sobre o particular como norma-princípio, deixando claro que, no seu entender, os princípios jurídicos são normas jurídicas, ou seja, desempenham função normativa. ${ }^{327}$

Neste ponto, esta observação ganha importância, sobretudo, para reafirmar o consenso de superação de qualquer concepção teórica que, eventualmente, descreva a principiologia jurídica negando sua normatividade. Trata-se de questão superada, pois, como lembra Eros Roberto GRAU, "[t]em a doutrina, de modo pacificado, reconhecido, nos princípios gerais do Direito, caráter normativo e "positivação"”. 328

\footnotetext{
${ }^{325}$ Humberto Bergmann ÁVILA. Repensando o "principio da supremacia,do interesse público sobre o particular". in Daniel SARMENTO (org.). Interesses públicos versus interesses privados:desconstruindo o princípio da supremacia do interesse público. p. 213.

${ }^{326}$ Humberto Bergmann ÁVILA. Repensando o "principio da supremacia,do interesse público sobre o particular". in Daniel SARMENTO (org.). Interesses públicos versus interesses privados:desconstruindo o princípio da supremacia do interesse público. p. 213-214.

${ }^{327}$ Na objetiva afirmação de Marcelo FIGUEIREDO: "princípios são normas jurídicas estruturais de um dado ordenamento jurídico". in Marcelo FIGUEIREDO. Probidade administrativa (comentários à lei 8.429 e legislação complementar) p. 115.

${ }^{328}$ Eros Roberto GRAU. A ordem econômica na constituição de 1988., p. 140. No mesmo sentido, entre outros, Luís Roberto BARROSO elucida: "É importante assinalar, logo de início, que já se encontra superada a distinção que outrora se fazia entre norma e princípio. A dogmática moderna avaliza o entendimento de que as normas jurídicas, em geral, e as normas constitucionais, em particular, podem ser enquadradas em duas
} 
Para os fins desta pesquisa, com efeito, considera-se a normatividade dos princípios jurídicos uma premissa já estabelecida, um consenso ex-anti ao debate doutrinário em questão. Contudo, também como se pode observar, isso não desvenda, ainda, o ponto fundamental do problema, deflagrado pela divergência teórica acerca da incompatibilidade da supremacia do interesse público sobre o particular com o conceito de norma jurídica principiológica - ou simplesmente, princípio jurídico -, nos termos descritos por Humberto Bergmann ÁVILA.

De acordo com as palavras do mencionado autor, verifica-se um conflito no entrelaçamento entre os aspectos conceitual e principiológico indissociáveis da divergência teórica que, nesta dimensão de análise, polemiza a palavra supremacia, tal como se ela não pudesse designar, conceitualmente, nenhuma norma jurídica de natureza principiológica.

Para prosseguimento, então, há de se investigar, no discurso de Humberto Bergmann ÁVILA, o conflito ora verificado. Eis, assim, a trilha a ser explorada pelo tópico seguinte.

\subsection{A incompatibilidade da supremacia do interesse público sobre o particular com o conceito de princípio jurídico nos termos descritos por Humberto Bergmann ÁviLA}

Porquanto construída pelos veios correntes da inegável simbiose existente entre linguagem e direito, ${ }^{329}$ pode-se dizer que a teoria jurídica nunca trabalhou suas questões principiológicas em apartado das conceituais. Irresistivelmente juntas, perfazem questões complexas, verificadas, logo de início, pelas dificuldades de definição conceitual que

\footnotetext{
categorias diversas: as normas-princípio e as normas-disposição. (...). as normas-princípio, ou simplesmente princípios, têm, normalmente, maior teor de abstração e uma finalidade mais destacada dentro do sistema". in Luís Roberto BARROSO. Interpretação e aplicação da constituição: fundamentos de uma dogmática constitucional transformadora., p. 151. Ainda, para uma visão sobre como este consenso se solidificara no decorrer da história - ou sobre a história da principiologia jurídica, contada por um constitucionalista brasileiro, ver: Paulo BONAVIDES. Curso de direito constitucional. p. 255-295.

${ }^{329}$ Conforme expõe Fernando SAINZ MORENO: "a relação entre o Direito e a linguagem é de vinculação essencial. Não existe o Direito sem a linguagem, da mesma forma que não existe o pensamento fora da linguagem. Trata-se, pois, de uma relação mais intensa que a de mera sustentação". in Fernando SAINZ MORENO. Conceptos jurídicos, interpretación y discricionariedad administrativa. P. 97. apud Dinorá Adelaide Musetti GROTTI. Conceitos jurídicos indeterminados e discricionariedade administrativa. in Cadernos de direito constitucional e ciência política, $\mathrm{n}^{\circ}$. 12. p. 84.
} 
envolvem o termo princípio - potencialmente mais plurívoco até que a própria noção jurídica de interesse público, investigada no capítulo anterior-.

Genaro R. CARRIÓ, em lições bastante conhecidas pela doutrina brasileira, ${ }^{330}$ procurou esmiuçar os inúmeros sentidos através dos quais a expressão princípio jurídico pode ser tomada, apresentando, neste mister, nada menos que onze alternativas conceituais. ${ }^{331}$ Destarte, esta pluralidade de conceitos também resta facilmente verificada com o simples folhear de páginas das obras doutrinárias que, por opção metodológica, procedem à exposição, em modo comparativo, das distintas contribuições teóricas trazidas nos discursos de tantos outros juristas que também já se debruçaram sobre o tema. ${ }^{332}$

$\mathrm{Na}$ senda do debate investigado, vale dizer, Humberto Bergmann ÁVILA reconhece que o "[o] uso do termo "princípio" está longe de ser uniforme",333 e, por isso, aduz que "[u]ma descrição unitária dos princípios jurídicos enfrenta soberbas dificuldades". ${ }^{334}$ Esta é, em suma, a premissa inicial para o desenvolvimento de sua ideia de inadequação semântica, tratada no tópico precedente. E nada obstante, é em razão desta inviabilidade da "descrição unitária dos princípios jurídicos" que o autor passa, para sustentar a sua tese - a da incompatibilidade do princípio da supremacia do interesse público sobre o particular com o conceito de princípio jurídico fornecido pela Teoria Geral do Direito -, a confrontar a teoria principiológica de Celso Antônio BANDEIRA de

\footnotetext{
${ }^{330}$ As lições de Genaro R. CARRIÓ são invocadas em diversos títulos da doutrina brasileira. Neste sentido, ver, entre outros: Eros Roberto GRAU. Ensaio e discurso sobre a interpretação/aplicação do direito., p. 131.; Ruy Samuel ESPÍNDOLA. Conceitos de princípios constitucionais. p. 48-49.; Daniel Wunder HACHEM. Princípio constitucional da supremacia do interesse público. p. 131.

${ }^{331}$ Genaro R. CARRIÓ. Notas sobre derecho y lenguaje. p. 209-212.

${ }^{332}$ Por razões lógicas, percebe-se que esse tipo de estudo tem sido constante especialmente no âmbito do direito constitucional. Neste sentido, é notável a abrangência teórica do capítulo que trata "dos princípios gerais de direito aos princípios constitucionais" no Curso de direito constitucional, de Paulo BONAVIDES, publicado pela editora Malheiros. Já como exemplo de trabalho monográfico específico sobre o tema, vale mencionar: Ruy Samuel ESPÍNDOLA. Conceito de princípios constitucionais., publicado pela editora Revista dos Tribunais. Nada obstante, para citar uma obra de direito administrativo em que esta metodologia também fora utilizada, consultar os Princípios de direito administrativo, escrito por Mateus Eduardo Siqueira Nunes BERTONCINI e publicado pela editora Malheiros.

${ }^{333}$ Humberto Bergmann ÁVILA. Repensando o "principio da supremacia,do interesse público sobre o particular". in Daniel SARMENTO (org.). Interesses públicos versus interesses privados:desconstruindo o princípio da supremacia do interesse público. p. 175.

${ }^{334}$ Humberto Bergmann ÁVILA. Repensando o "principio da supremacia,do interesse público sobre o particular". in Daniel SARMENTO (org.). Interesses públicos versus interesses privados:desconstruindo o princípio da supremacia do interesse público. p. 175.
} 
MELLO com pressupostos teóricos extraídos da formulação desenvolvida por Robert ALEXY. ${ }^{335}$

Isto fica claro quando, em relação ao princípio colocado em debate, Humberto Bergmann ÁVILA questiona o já conhecido conceito que, conforme propõe Celso Antônio BANDEIRA de MELLO, "[p]roclama a superioridade do interesse da coletividade, firmando a prevalência dele sobre o particular, como condição, até mesmo, da sobrevivência e asseguramento deste último"; ;36 e direciona suas críticas, escorando-se no pensamento de Robert ALEXY, para desconstruir esta concepção - a da prevalência do interesse público sobre o particular - com argumentos sempre no sentido de que os princípios jurídicos, por correção conceitual, constituem "normas de otimização concretizáveis em vários graus"337 cuja relação de prevalência entre eles não pode ser previamente firmada, posto que verificada apenas diante do caso concreto. ${ }^{338}$

Sem embargo, dos próprios dizeres de Humberto Bergmann ÁVILA, convém transcrever:

“O importante foi registrado por ALEXY: "Essa relação de tensão não poderia ser resolvida no sentido de uma absoluta prevalência de uma dessas obrigações do Estado, nenhuma dessas obrigações ganha diretamente a prevalência. $O$ conflito deve ser resolvido, muito mais, por meio de uma ponderação entre os interesses conflitantes". Em vez de uma "relação abstrata de prevalência absoluta", deve ser descrita uma "relação concreta de prevalência relativa", cujo conteúdo depende das circunstâncias do caso e cujos efeitos só são

\footnotetext{
${ }^{335}$ Cf. Fábio Medina OSÓRIO. Existe uma supremacia do interesse público sobre o privado no direito administrativo brasileiro? in Revista dos Tribunais. Vol. 770. p. 62

${ }^{336}$ apud Humberto Bergmann ÁVILA. Repensando o "princípio da supremacia,do interesse público sobre o particular". in Daniel SARMENTO (org.). Interesses públicos versus interesses privados:desconstruindo o princípio da supremacia do interesse público. p. 171.

${ }^{337}$ Humberto Bergmann ÁVILA. Repensando o "principio da supremacia,do interesse público sobre o particular". in Daniel SARMENTO (org.). Interesses públicos versus interesses privados:desconstruindo o princípio da supremacia do interesse público. p. 180.

${ }^{338}$ Cf. Humberto Bergmann ÁVILA. Repensando o "principio da supremacia,do interesse público sobre o particular". in Daniel SARMENTO (org.). Interesses públicos versus interesses privados:desconstruindo o princípio da supremacia do interesse público. p. 185. No mesmo sentido, podem ser destacadas as palavras de Gustavo BINENBOJM: "Conceitualmente, é possível, de plano, apartar o "princípio" em tela de toda construção doutrinária acerca dos princípios jurídicos. Neste ponto, fica claro o divórcio entre a regra abstrata de prevalência absoluta em favor do interesse público e a aplicação gradual dos princípios proporcionada pelo caráter abstrato dos mesmos". in Gustavo BINENBOJM. Da supremacia do interesse público ao dever de proporcionalidade: um novo paradigma para o direito administrativo. in Daniel SARMENTO (org.). Interesses públicos versus interesses privados:desconstruindo o princípio da supremacia do interesse público. p. 140.
} 
desencadeados caso verificadas as condições de prevalência do princípio envolvido. ${ }^{339}$

Objetivamente, depois de percorrido todo o caminho argumentativo desenvolvido por Humberto Bergmann ÁVILA, é de se presumir que as referidas concepções principiológicas de Celso Antônio BANDEIRA de MELLO e Robert ALEXY não sejam iguais. Por este quadro, a explícita aderência do autor ao conjunto de ideias encontradas nos livros de Robert ALEXY não impede, naturalmente, a formulação de uma hipótese, a ser investigada no tópico a seguir: a hipótese de que a adequação ou inadequação semântica da supremacia do interesse público sobre o particular ao conceito de normaprincípio/princípio jurídico depende - e parece mesmo lógico que seja assim - da teoria jurídico-principiológica adotada.

Desta feita, para os fins almejados nesta dimensão de análise, torna-se evidente a necessidade de se investigar o debate doutrinário acerca do princípio da supremacia do interesse público sobre o particular no direito administrativo brasileiro à luz do discurso de Humberto Bergmann ÁVILA - já, aliás, detidamente examinado desde o início do presente capítulo - mas tendo como foco de abordagem, a partir deste momento, a efetiva visualização da linha teórica que distingue o conceito de princípio jurídico segundo as propostas destes dois autores - Celso Antônio BANDEIRA de MELLO e Robert ALEXY ,- consoante se fará a partir de agora.

\subsection{O problema ${ }^{340}$ do conceito de princípio jurídico no discurso de Humberto Bergmann ÁVILA: algumas inflexões sobre as proposições conceituais de Celso Antônio BANDEIRA de MELLO e Robert ALEXY no direito administrativo brasileiro}

\footnotetext{
339 Humberto Bergmann ÁVILA. Repensando o "princípio da supremacia,do interesse público sobre o particular”. in Daniel SARMENTO (org.). Interesses públicos versus interesses privados:desconstruindo o princípio da supremacia do interesse público. p. 185-186.

340 Neste ponto, utilizo a palavra "problema" não para classificar o conceito de princípio jurídico defendido por Humberto Bergmann Ávila como problemático, mas para colocar o seu discurso em forma de problema e a partir disso, examiná-lo à luz das divergências teóricas que integram esta dimensão de análise do debate.
} 
Para problematizar o discurso de Humberto Bergmann ÁVILA é preciso seguir a linha de pensamento que ele propõe e que, neste caso, determina que "(...) a incompatibilidade do "princípio" da supremacia do interesse público sobre o particular com o conceito de princípio jurídico fornecido pela Teoria Geral do Direito só pode ser bem demonstrada com a referida distinção entre princípios e regras". 341

Em conformidade com esta proposta, aproveitam-se os dizeres de Virgílio Afonso da SILVA na demonstração de que “(...) o conceito de princípio usado por Robert Alexy, como espécie de norma contraposta à regra jurídica, é bastante diferente do conceito de princípio tradicionalmente usado na literatura jurídica brasileira". ${ }^{342} \mathrm{O}$ autor lembra que, no Brasil, os “““[p]rincípios” são, tradicionalmente, definidos como "mandamentos nucleares" ou "disposições fundamentais" de um sistema, ou ainda como "núcleos de condensações", 343 e que tais expressões, apesar de variadas, apontam a seguinte convergência de sentido: “(...) princípios seriam as normas mais fundamentais do sistema, enquanto que as regras costumam ser definidas como uma concretização desses princípios e teriam, por isso, caráter mais instrumental e menos fundamental". 344

É precisamente dentro desta concepção - dita tradicional - que se insere o conceito de princípio jurídico consagrado na lição de Celso Antônio BANDEIRA de MELLO:

"Princípio é, pois, por definição, mandamento nuclear de um sistema, verdadeiro alicerce dele, disposição fundamental que se irradia sobre diferentes normas, compondo-lhes o espírito e servindo de critério para exata compreensão e inteligência delas, exatamente porque define a lógica e a racionalidade do sistema normativo, conferindo-lhe a tônica que lhe dá sentido harmônico". 345

\footnotetext{
${ }^{341}$ Humberto Bergmann ÁVILA. Repensando o "princípio da supremacia,do interesse público sobre o particular”. in Daniel SARMENTO (org.). Interesses públicos versus interesses privados:desconstruindo o princípio da supremacia do interesse público. p. 184.

${ }^{342}$ Virgílio Afonso da SILVA. Princípios e regras: mitos e equívocos acerca de uma distinção. in Revista Latino-Americana de Estudos Constitucionais 1. p. 612.

${ }^{343}$ Virgílio Afonso da SILVA. Princípios e regras: mitos e equívocos acerca de uma distinção. in Revista Latino-Americana de Estudos Constitucionais 1. p. 612.

${ }^{344}$ Virgílio Afonso da SILVA. Princípios e regras: mitos e equívocos acerca de uma distinção. in Revista Latino-Americana de Estudos Constitucionais 1. p. 612.

${ }^{345}$ Celso Antônio BANDEIRA de MELLO. Curso de direito administrativo. 28 ed. p. 54.
} 
Veja-se que os mesmos parâmetros teóricos são acolhidos por Geraldo ATALIBA, ao definir que "[o]s princípios são a chave e a essência de todo o direito. Não há direito sem princípios. As simples regras jurídicas de nada valem se não tiverem apoiadas em princípios sólidos". ${ }^{346}$ Entretanto, distinta parametrização parece modular os elementos conceituais apresentados na teoria de Robert ALEXY:

“(...) [P]rincípios são normas que ordenam que se realize algo na maior medida do possível, em relação com as possibilidades jurídicas e fáticas. Os princípios são, por conseguinte, mandamentos de otimização que se caracterizam porque podem ser cumpridos em diversos graus e porque a medida ordenada de seu cumprimento não só depende das possibilidades fáticas, mas também das possibilidades jurídicas. (...). Em contrapartida, as regras são normas que exigem um cumprimento pleno e, nessa medida, podem sempre ser somente cumpridas ou não. Se uma regra é válida, então é obrigatório fazer precisamente o que se ordena, nem mais nem menos. As regras contêm por isso, determinações no campo do possível fática e juridicamente". 347

Como explica Virgílio Afonso da SILVA, não é difícil identificar a principal diferença entre as duas proposições teóricas acima colacionadas, ${ }^{348}$ já que na teoria de Robert ALEXY, o conceito de princípio jurídico “(...) é um conceito que nada diz sobre a fundamentalidade da norma. Assim, um princípio pode ser um "mandamento nuclear do sistema”, mas pode também não o ser, já que uma norma é um princípio apenas em razão de sua estrutura normativa e não de sua fundamentalidade". ${ }^{349} \mathrm{E}$ isso ocorre porque, ao contrário do que se verifica na proposta de Celso Antônio BANDEIRA de MELLO, o critério utilizado por esta teoria para diferenciar as espécies normativas - princípios e

\footnotetext{
${ }^{346}$ Geraldo ATALIBA. Mudança da constituição. in Revista de Direito Público , n. ${ }^{\circ}$ 86. p. 181.

${ }^{347}$ Tradução livre. Na fonte consultada: “(...) principios son normas que ordenan que se realice algo em la mayor medida posible, em relación com las posibilidades jurídicas y fáticas. Los princípios son, por conseguiente, mandatos de optimización que se caraterizan por que pueden ser cumplidos en diversos grados y porque la medida ordenada de su cumplimiento no solo depende de las posibilidades fácticas, sino también de las posibilidades jurídicas. (...). En cambio, las reglas son normas que exigen um cumplimiento pleno y, em esa medida, pueden siempre ser sólo cumplidas o incumplidas. Si uma regla es válida, entonces es obligatorio hacer precisamente ló que ordena, ni más ni menos. Las reglas contienen por ello determinaciones em el campo de ló posible fáctica y juridicamente". in Robert ALEXY. Derecho y razón práctica. p. 34.

${ }^{348}$ Cf. Virgílio Afonso da SILVA. Princípios e regras: mitos e equívocos acerca de uma distinção. in Revista Latino-Americana de Estudos Constitucionais 1. p. 613.

${ }^{349}$ Virgílio Afonso da SILVA. Princípios e regras: mitos e equívocos acerca de uma distinção. in Revista Latino-Americana de Estudos Constitucionais 1. p. 613.
} 
regras - não leva em consideração o grau de importância ou nuclearidade, mas, sim, a estrutura lógico-normativa que caracteriza cada uma destas espécies. ${ }^{350}$ Sintetizando a questão, terminologicamente, pode-se dizer - aliás, como já se viu - que na primeira proposição, princípios jurídicos são disposições fundamentais do sistema; na segunda, são mandamentos de otimização.

Prosseguindo, chama atenção, na doutrina publicista brasileira, a sua grande recepção ao modelo teórico oferecido por Robert ALEXY. Trata-se, pois, de outra questão levantada por Virgílio Afonso da SILVA, quando observa: “[n]ão são poucos os trabalhos - e não somente na área constitucional - que têm usado a distinção de Alexy entre princípios e regras como ponto de partida". ${ }^{351}$ E subjaz, em tentativa de explicação para o fato observado, uma forte crítica manifestada pelo autor, noutra passagem, com as seguintes palavras:

\begin{abstract}
"Não é difícil perceber que a doutrina jurídica recebe de forma muitas vezes pouco ponderada as teorias desenvolvidas no exterior. E, nesse cenário, a doutrina alemã parece gozar de uma posição privilegiada, já que, por razões desconhecidas, tudo o que é produzido na literatura jurídica germânica parece ser encarado como revestido de uma aura de cientificidade e verdade indiscutíveis". ${ }^{352}$
\end{abstract}

É certo que com o fortalecimento da temática principiológica, muito em razão da constitucionalização do direito, ${ }^{353}$ a teoria de Robert ALEXY tem servido como discurso de autoridade largamente utilizado também no âmbito do direito administrativo. No caso específico de textos que discutem o princípio da supremacia do interesse público sobre o particular no direito administrativo brasileiro, as lições proferidas pelo jurista alemão

\footnotetext{
350 “(...) [Pela teoria de Robert ALEXY] uma norma é um princípio não por ser fundamental, mas por ter a estrutura de um mandamento de otimização". in Virgílio Afonso da SILVA. A constitucionalização do direito: os direitos fundamentais nas relações entre particulares. p. 36.

${ }^{351}$ Virgílio Afonso da SILVA. A constitucionalização do direito: os direitos fundamentais nas relações entre particulares. p. 35.

${ }^{352}$ Virgílio Afonso da SILVA. Interpretação constitucional e sincretismo metodológico. in Virgílio Afonso da SILVA (org.). Interpretação constitucional. p. 116.

353 Observação feita no mesmo sentido em que Maria Sylvia Zanella DI PIETRO quando, ao tratar do tema da constitucionalização do direito administrativo, afirmou que "[t]alvez se falasse melhor em constitucionalização dos princípios do direito administrativo". in Maria Sylvia Zanella DI PIETRO. $O$ princípio da segurança jurídica diante do princípio da legalidade. in. Thiago MARRARA (org.). Princípios de direito administrativo:legalidade, segurança jurídica, impessoalidade, publicidade, motivação, eficiência, moralidade, razoabilidade, interesse público. p. 9.
} 
serviriam, segundo alguns autores, ${ }^{354}$ para desmistificar a supremacia - esvaziando o conteúdo principiológico desta palavra - do interesse público, contextualizada à emergência da "teoria dos direitos fundamentais" 355 do homem.

Dentro desta questão, ainda, Virgílio Afonso da SILVA alerta para a existência de trabalhos acadêmicos que partem da distinção entre princípios e regras formulada por Robert ALEXY sem, no entanto, abandonar a clássica definição principiológica de Celso Antônio BANDEIRA de MELLO. Fora do mérito de se dizer qual definição seria a mais correta, o vício que contamina esse tipo de trabalho consiste em confundir e misturar duas teorias que são incompatíveis, ${ }^{356}$ conforme devidamente aclarado nos parágrafos anteriores.

Qualquer sugestão de alinhamento entre as proposições conceituais externadas por Celso Antônio BANDEIRA de MELLO e Robert ALEXY é incorreta. Com efeito, esse fenômeno - em que teorias incompatíveis são adotadas como se compatíveis fossem recebe de Virgílio Afonso da SILVA o nome de "sincretismo metodológico".357

O alerta de Virgílio Afonso da SILVA, tal como acima relatado, é importantíssimo para que se possa refletir acerca do impacto das teorias estrangeiras sobretudo, acerca da forma como essas teorias são aqui interpretadas à luz de todo o contexto jurídico brasileiro - nas questões de direito público, de um modo geral. Todavia, não se pode dizer que esse sincretismo metodológico esteja presente no discurso de Humberto Bergmann ÁVILA; bem ao revés, o autor separa as teorias ora cotejadas, sustentando uma tese de incorreção do conceito de princípio jurídico de Celso Antônio

\footnotetext{
354 Tais como Georges ABBOUD. O mito da supremacia do interesse público sobre o privado: a dimensão constitucional dos direitos fundamentais e os requisitos necessários para se autorizar restrição a direitos fundamentais. in Revista dos Tribunais. Vol. 100. $\mathrm{n}^{\circ}$. 907. p. 61-119.; Ricardo Catunda N. GUEDES. Supremacia do interesse público sobre interesse privado em face dos direitos fundamentais. in Revista Mestrado em Direito. Ano 7. n. 1. p. 273-287.; Flávio Quinaud PEDRON. O dogma da supremacia do interesse público e seu abrandamento pela jurisprudência do Supremo Tribunal Federal através da técnica da ponderação dos princípios. in A\&C-Revista de Direito Administrativo \& Constitucional, $\mathrm{n}^{\circ}$. 40. p. 271 290.; entre outros. Sem embargo, anote-se que esta divergência que especificamente opõe o princípio da supremacia do interesse público sobre o particular com a teoria dos direitos fundamentais será abordada em outra dimensão de análise, desenvolvida no próximo e derradeiro capítulo desta pesquisa.

355 Teoria que dá nome a sua obra mais divulgada no Brasil: Robert ALEXY. Teoria dos direitos fundamentais.

356 Cf. Virgílio Afonso da SILVA. Princípios e regras: mitos e equívocos acerca de uma distinção. in Revista Latino-Americana de Estudos Constitucionais 1. p. 625.

${ }^{357}$ in Virgílio Afonso da SILVA. Princípios e regras: mitos e equívocos acerca de uma distinção. in Revista Latino-Americana de Estudos Constitucionais 1. p. 625.
} 
BANDEIRA de MELLO com argumentos baseados na distinção entre princípios e regras elaborada por Robert ALEXY.

Diante, portanto, da tese sustentada por Humberto Bergmann ÁVILA, faz sentido que, aproximando-se do fechamento da problematização sugerida nesta dimensão de análise, o exame acerca da incompatibilidade da supremacia do interesse público sobre o particular com o conceito de princípio jurídico, na esteira do debate que é travado pela doutrina administrativista brasileira, seja, no próximo e também último tópico deste capítulo, delimitado ao modelo teórico propagado por Robert ALEXY, segundo o qual princípios jurídicos são definidos como mandamentos de otimização e não como normas fundamentais no sistema.

Neste passo, para os fins da presente pesquisa, cumpre também observar a participação de Fábio Medina OSÓRIO neste debate, notadamente através do artigo elaborado em resposta às ideias de Humberto Bergmann ÁVILA, até aqui problematizadas.

5.4. Ainda sobre a - interpretação que se faz da - teoria de Robert ALEXY: o princípio da supremacia do interesse público sobre o particular como mandamento de otimização no discurso de Fábio Medina OSÓRIO

Com longas explicações, Fábio Medina OSÓRIO - no que é seguido por Daniel Wunder HACHEM ${ }^{358}$ - assim expressa sua discordância em relação ao discurso de Humberto Bergmann ÁVILA:

"Se considerada a Teoria dos Direitos Fundamentais de Robert Alexy, creio que o princípio da superioridade do interesse público seria, rigorosamente, um princípio, em numerosos casos, mas também poderia ser uma regra constitucional de prevalência automática em tantos outros, mormente quando essa norma definisse finalisticamente o interesse público a ser perseguido pelos agentes públicos e não houvesse espaço para alternativas.

$(\ldots)$

${ }^{358}$ Cf. Daniel Wunder HACHEM. Princípio constitucional da supremacia do interesse público. p. 252. 
À luz da já mencionada classificação de regras e princípios, o "princípio" da superioridade do interesse público sobre o privado poderia ser, além de princípio, uma "regra". Quando se trata de vislumbrar o único fim possível para a Administração e os agentes públicos, notadamente para uma função administrativa, ele parece atuar, ao menos em muitos casos, como um "tudo ou nada" nas ações administrativas. Ao incidir, determina que se atenda o interesse público em detrimento do privado, tornando imperiosa uma atuação do agente público neste sentido, é dizer, situando em plano secundário e subalterno os interesses privados seus ou de terceiros, prevalecendo o interesse público. Não é, em geral, um dever-ser apenas "ideal", tampouco um mandado de otimização, embora se possa falar em realização do interesse público na maior medida possível em numerosas situações. Seria uma regra constitucional presente na norma que se encontra no sistema, uma norma vinculante que permite o controle de validade de outras normas jurídicas, sejam regras, sejam princípios". 359

Das razões apresentadas por Fábio Medina OSÓRIO, impõe-se extrair uma nova possibilidade argumentativa que, naturalmente, incrementa a complexidade do debate nesta dimensão de análise, ou seja, torna mais complexa a divergência teórica acerca dos aspectos conceitual e normativo sobre os quais seria possível, de acordo com a teoria adotada, conferir ou refutar a qualidade principiológica da supremacia do interesse público sobre o particular.

Isto acontece porque, como já visto, antes de se trazer a lume a extensa passagem acima transcrita, mapeou-se a divergência ora investigada por meio de uma básica divisão, extremada em dois caminhos distintos, posto que orientados por acepções discordantes em torno do conceito de princípio jurídico. Sendo assim, no primeiro caminho deste mapa, por onde se definem os princípios de direito como disposições fundamentais do sistema, nada há que se cogitar acerca da potencial incompatibilidade - ou até mesmo inadequação semântica - de uma norma principiológica denominadamente suprema com o grau de fundamentalidade máxima que ela desempenha dentro do regime jurídico-administrativo; já no segundo, por onde as normas principiológicas são conceitualmente designadas como mandamentos de otimização, a supremacia do interesse público sobre o particular passa a

359 Fábio Medina OSÓRIO. Existe uma supremacia do interesse público sobre o privado no direito administrativo brasileiro? in Revista dos Tribunais. Vol. 770. p. 87-88. 
ser considerada incompatível com esta mencionada otimização ou, dito de outra forma, com a sua realização, na maior medida possível, diante das condições fáticas e jurídicas conformadoras de sua rota de colisão com outros princípios também presentes no caso concreto. $^{360}$

Mas a resposta de Fábio Medina OSÓRIO à Humberto Bergmann ÁVILA sugere uma terceira possibilidade, também buscando sintonia com a classificação das normas jurídicas elaborada por Robert ALEXY; elaboração esta que explicará, dentro da linha de pensamento acima colacionada, a dupla função normativa exercida pela supremacia do interesse público sobre o particular na conjuntura do sistema, ora funcionando como regra, ora funcionando como princípio jurídico. Destarte, aos olhos de Fábio Medina OSÓRIO, vale notar, a supremacia do interesse público sobre o particular tenderá a prevalecer, finalisticamente, como regra jurídica que impõe a razão definitiva do agir administrativo; porém, sua realização deverá ocorrer na maior medida possível, sempre, de acordo com as circunstâncias de fato e de direito do caso concreto, isto é, nas ocasiões em que ela funcionará, portanto, como princípio jurídico.

Conforme já se viu, no entender daqueles que diferenciam regras e princípios jurídicos avaliando suas respectivas estruturas normativas, as primeiras designam normas que, pelas próprias palavras de Robert ALEXY, exigem sempre um cumprimento pleno. ${ }^{361}$ Neste sentido, a norma jurídica que a chamada doutrina tradicional, a grosso modo, reconhece como "matriz suprema ordenadora" de qualquer construção publicística porque "proclama a superioridade do interesse da coletividade, firmando a prevalência dele sobre o particular, como condição, até mesmo, da sobrevivência e asseguramento deste último",362 poderia, realmente, de acordo com a teoria formulada por este autor, ser classificada como regra jurídica - uma regra coerente, aliás, com o sistema que tradicionalmente recebe o nome de regime jurídico-administrativo, como também já se

\footnotetext{
${ }^{360}$ Cf. Virgílio Afonso da SILVA. A constitucionalização do direito: os direitos fundamentais nas relações entre particulares. p. 34.

${ }^{361}$ Cf. Robert ALEXY. Derecho y razón práctica. p. 34.

${ }^{362}$ Invocação expressa, na sequência dos conteúdos colocados entre aspas, das palavras eternizadas por José CRETELLA JR. e Celso Antônio BANDEIRA de MELLO, como dois dos maiores expoentes da doutrina que hoje é considerada como tradicional. Assim, respectivamente: José CRETELLA JR.. Princípios informativos do direito administrativo. in Revista de Direito Administrativo, vol. 93. p. 4; e Celso Antônio BANDEIRA de MELLO. Curso de direito administrativo. 28 ed. p. 70.
} 
$\mathrm{viu}^{363}$ - . Sucede que, conforme arremata Daniel Wunder HACHEM, “(...) o que certos autores chamam de princípios, outros chamarão de regras". 364

Haveria, então, na verdade, uma contradição lógica e patente no discurso de Fábio Medina OSÓRIO, a considerar, com base na teoria de Robert ALEXY, que esta norma de prevalência suprema, ou seja, de cumprimento pleno dentro do sistema, pudesse também ser realizada em graus menores, já que a medida ordenada no cumprimento de qualquer princípio não depende apenas das possibilidades fáticas, mas também das possibilidades jurídicas existentes, ${ }^{365}$ verificadas sempre no caso concreto.

Para Humberto Bergmann ÁVILA, pois, do modo como Robert ALEXY sistematiza o funcionamento dos princípios no ordenamento jurídico, a descrição abstrata da supremacia do interesse público sobre o particular não permite que sua concretização ocorra de maneira gradual, “(...) pois a prevalência é a única possibilidade (ou grau) normal de sua aplicação, e todas as outras possibilidades de concretização somente consistiriam em exceções e, não, graus"; 366 daí, por conseguinte, a sua inadequação semântica ao conceito de princípio jurídico.

Outrossim, o autor prossegue:

\begin{abstract}
“(...) sua descrição abstrata permite apenas uma medida de concretização, a referida "prevalência", em princípio independente das possibilidades fáticas e normativas; sua abstrata explicação exclui, em princípio, a sua aptidão e necessidade de ponderação, pois o interesse público deve ter maior peso relativamente ao interesse particular, sem que diferentes opções de solução e uma máxima realização das normas em conflito (e dos interesses que elas resguardam) sejam ponderadas". 367
\end{abstract}

\footnotetext{
${ }^{363}$ Consultar, no segundo capítulo desta pesquisa, os tópicos 2.2. e 2.6. retro.

${ }^{364}$ Daniel Wunder HACHEM. Princípio constitucional da supremacia do interesse público. p. 251.

${ }^{365}$ Cf. Robert ALEXY. Derecho y razón práctica. p. 34.

366 Humberto Bergmann ÁVILA. Repensando o "princípio da supremacia,do interesse público sobre o particular”. in Daniel SARMENTO (org.). Interesses públicos versus interesses privados:desconstruindo o princípio da supremacia do interesse público. p. 184.

367 Humberto Bergmann ÁVILA. Repensando o "princípio da supremacia,do interesse público sobre o particular”. in Daniel SARMENTO (org.). Interesses públicos versus interesses privados:desconstruindo o princípio da supremacia do interesse público. p. 184-185.
} 
É de se notar que a mesma linha de argumentação será desenvolvida por outros integrantes do debate. Assim, para Gustavo BINENBOJM, por exemplo, “(...) não há como conciliar no ordenamento jurídico um "princípio" que, ignorando as nuances do caso concreto, preestabeleça que a melhor solução consubstancia-se na vitória do interesse público", 368 eis que, no seu entender, "[o] "princípio" em si afasta o processo de ponderação, fechando as portas para os interesses privados envolvidos". ${ }^{369}$ Veja-se, com efeito, que são dizeres praticamente idênticos aos de Daniel SARMENTO, quando defende que a “(...) supremacia do interesse público sobre o particular, ao afirmar a superioridade $a$ priori de um dos bens em jogo sobre o outro, elimina qualquer possibilidade de sopesamento, premiando de antemão, com a vitória completa e cabal, o interesse público envolvido". ${ }^{370}$ E não é diferente, neste conjunto crítico, a posição de Patrícia BAPTISTA, então manifestada nos seguintes termos:

"De fato, ao trazer em si uma predefinição do resultado que deve advir da sua aplicação, um princípio que enuncie a supremacia do interesse público comporta pouca, ou nenhuma, possibilidade de gradação ou ponderação quando em conflito com outros princípios do ordenamento jurídico. Tanto mais quando confrontado com um outro princípio que é quase como uma antítese sua, o da proporcionalidade". ${ }^{371}$

Tal como acima referida, a máxima da proporcionalidade - comumente apontada como sinônimo de razoabilidade ${ }^{372}$-, também constitui tema dos mais polêmicos nas atuais mesas de debate sobre direito público e teoria geral do direito no Brasil. Desempenhando, pois, importante papel na operacionalização da normatividade principiológica, ela, por si própria, é identificada como princípio jurídico - aplicado nos chamados juízos de ponderação ou sopesamento - pela maior parte da doutrina. ${ }^{373}$ Ocorre

\footnotetext{
${ }^{368}$ Gustavo BINENBOJM. Uma teoria do direito administrativo: direitos fundamentais, democracia $e$ constitucionalização. p. 98.

369 Gustavo BINENBOJM. Uma teoria do direito administrativo: direitos fundamentais, democracia $e$ constitucionalização. p. 98.

${ }^{370}$ Daniel SARMENTO. Interesses públicos vs. interesses privados na perspectiva da teoria e da filosofia constitucional. in Daniel SARMENTO (org.). Interesses públicos versus interesses privados:desconstruindo o princípio da supremacia do interesse público. p. 100.

${ }^{371}$ Patrícia BAPTISTA. Transformações do direito administrativo. p. 189.

${ }^{372}$ Cf. Virgílio Afonso da SILVA. O proporcional e o razoável. in Revista dos Tribunais. Vol. 798. p. 23.

${ }^{373}$ Com efeito, denso trabalho sustentando o caráter principiológico da razoabilidade e da proporcionalidade é a dissertação de mestrado de José Roberto Pimenta OLIVEIRA, publicada como Os princípios da razoabilidade e da proporcionalidade no direito administrativo brasileiro, pela editora Malheiros. Em sentido contrário, todavia, há quem entenda que a proporcionalidade não é princípio, mas, sim, regra jurídica.
} 
que paralelamente à discussão acerca de sua natureza ou essência principial exsurge, conforme adverte Fernando Dias MENEZES de ALMEIDA, “(...) uma excessiva ênfase na análise estrutural do funcionamento dos princípios em detrimento de uma análise finalística do conteúdo valorativo que encerram", ${ }^{374}$ razão pela qual, o autor não poderia, em desfecho, deixar de observar:

\begin{abstract}
"Por outras palavras, a solução "universal" fornecida pela ponderação de princípios - num raciocínio de proporcionalidade que, muito antes de ser imposição normativa do Direito contemporâneo, é elemento inexorável de qualquer processo de decisão jurídica, em todos os níveis de criação normativa dentro dos diversos escalões do ordenamento jurídico". 375
\end{abstract}

Todavia, retornando ao cerne da questão ora investigada, já se pode notar que todas as críticas endereçadas ao princípio da supremacia do interesse público sobre o particular nesta dimensão de análise não transbordam da arguição de sua incompatibilidade, como diz Daniel SARMENTO, “(...) com o princípio da proporcionalidade, que constitui importantíssimo parâmetro para aferição da constitucionalidade das restrições aos direitos fundamentais". ${ }^{376}$

O problema desta objeção, entretanto, é que os defensores da supremacia do interesse público sobre o particular parecem não rejeitar a aplicação da proporcionalidade como critério de ponderação ou sopesamento na aplicação do princípio ora debatido. Irene Patrícia NOHARA, a propósito, afirma expressamente que “(...) a doutrina jamais defendeu que a aplicação desse fundamento do regime jurídico público pudesse ser feita

Nesta direção, ver: Virgílio Afonso da SILVA. O proporcional e o razoável. in Revista dos Tribunais. Vol. 798. p. 23-50.

${ }^{374}$ Fernando Dias MENEZES de ALMEIDA. Princípio da impessoalidade. in. Thiago MARRARA (org.). Princípios de direito administrativo:legalidade, segurança jurídica, impessoalidade, publicidade, motivação, eficiência, moralidade, razoabilidade, interesse público. p. 110.

${ }^{375}$ Fernando Dias MENEZES de ALMEIDA. Princípio da impessoalidade. in. Thiago MARRARA (org.). Princípios de direito administrativo:legalidade, segurança jurídica, impessoalidade, publicidade, motivação, eficiência, moralidade, razoabilidade, interesse público. p. 110.

${ }^{376}$ Daniel SARMENTO. Interesses públicos vs. interesses privados na perspectiva da teoria e da filosofia constitucional. in Daniel SARMENTO (org.). Interesses públicos versus interesses privados:desconstruindo o princípio da supremacia do interesse público. p. 99. 
sem ponderação de razoabilidade/proporcionalidade e, portanto, ao arrepio de direitos fundamentais protegidos pela Constituição". ${ }^{377}$

A questão - que se resume em dizer que a exigência da razoabilidade/proporcionalidade sempre esteve presente na aplicação do princípio em pauta $^{378}$ - poderia até ser tratada como afirmação vazia e teoricamente descompromissada, não fosse o fato - lembrado por Maria Sylvia Zanella DI PIETRO - “(...) de que o poder de polícia (cuja própria razão de ser decorre do princípio da supremacia do interesse público) tem as características da necessidade, da eficácia e da proporcionalidade". ${ }^{379}$ No mais, a autora ainda assevera que a busca do equilíbrio, próprio no regramento de institutos forjados dentro do binômio autoridade e liberdade nunca fora desprezada nem pela doutrina tampouco pela jurisprudência, mesmo quando não invocadas expressões tais como proporcionalidade ou razoabilidade. ${ }^{380}$

De todo modo, é justamente neste ponto que convém o alerta de Fernando Dias MENEZES de ALMEIDA, qual seja o de evitar "a excessiva ênfase na análise estrutural do funcionamento dos princípios". É que diante do estágio atual do debate, conforme até aqui relatado, parece ser evidente a pouca utilidade deste aprofundamento teórico, no sentido de buscar a definição acerca de quais conceitos de princípio jurídico podem ser concretizados mediante raciocínios baseados na aferição do que é razoável/proporcional ou não. Ao contrário, restando claro que nenhum autor de direito administrativo rejeita o princípio/técnica/regra da razoabilidade/proporcionalidade na aplicação do princípio da supremacia do interesse público sobre o particular, urge extraí-lo, na verdade, como consenso doutrinário de todo o conteúdo então debatido, isto é, como um dos pontos de concordância geral a partir dos quais este debate pode evoluir.

\footnotetext{
377 Irene Patrícia NOHARA. Reflexões críticas acerca da tentativa de desconstrução do sentido da supremacia do interesse público no direito administrativo. in. Maria Sylvia Zanella DI PIETRO e Carlos Vinícius Alves RIBEIRO (coord.). Supremacia do interesse público e outros temas relevantes do direito administrativo. p. 150.

${ }^{378}$ Cf. Maria Sylvia Zanella DI PIETRO. O princípio da supremacia do interesse público: sobrevivência diante dos ideais do neoliberalismo. in. Maria Sylvia Zanella DI PIETRO e Carlos Vinícius Alves RIBEIRO (coord.). Supremacia do interesse público e outros temas relevantes do direito administrativo. p. 100.

${ }^{379}$ Maria Sylvia Zanella DI PIETRO. O princípio da supremacia do interesse público: sobrevivência diante dos ideais do neoliberalismo. in. Maria Sylvia Zanella DI PIETRO e Carlos Vinícius Alves RIBEIRO (coord.). Supremacia do interesse público e outros temas relevantes do direito administrativo. p. 100.

${ }^{380}$ Cf. Maria Sylvia Zanella DI PIETRO. O princípio da supremacia do interesse público: sobrevivência diante dos ideais do neoliberalismo. in. Maria Sylvia Zanella DI PIETRO e Carlos Vinícius Alves RIBEIRO (coord.). Supremacia do interesse público e outros temas relevantes do direito administrativo. p. 100.
} 
Por conseguinte, parece claro também que mais importante que o aprofundamento teórico "na análise estrutural" - e conceitual - da razoabilidade/proporcionalidade na aplicação do princípio da supremacia do interesse público sobre o particular seria, apenas, a exigência - por parte de todos - de sua demonstração, de forma lógica e coerente, como decorrência natural e obrigatória da chamada motivação que integra qualquer decisão administrativa ou judicial - questão, obviamente, a ser remetida também aos debates sobre discricionariedade, controle, conceitos jurídicos indeterminados e etc -.

Esta última percepção, contudo, por começar a fugir dos fins visados pela presente pesquisa, deve permanecer tão somente como mera sugestão de direcionamento do debate ora investigado, para um momento posterior ao da solidificação dos consensos doutrinários que esta dissertação persegue. 


\section{TERCEIRA DIMENSÃO DE ANÁLISE DO DEBATE: AS DIVERGÊNCIAS TEÓRICAS ACERCA DA CENTRALIDADE DO PRINCÍPIO DA SUPREMACIA DO INTERESSE PÚBLICO SOBRE O PARTICULAR NO ORDENAMENTO JURÍDICO BRASILEIRO}

\subsection{Supremacia do interesse público versus supremacia da dignidade da pessoa humana? Um dilema de hierarquia principiológica entre os administrativistas brasileiros}

Ao final de todo o exposto no capítulo anterior, verificou-se que do ponto de vista que observa a estrutura normativa dos princípios jurídicos, a exigência de ponderação/sopesamento - via manejo das máximas da razoabilidade/proporcionalidade dos interesses conflitados em cada caso apresenta-se, por definitivo, como “(...) ponto de convergência de todos os doutrinadores, inclusive daqueles que revisitam o tema da prevalência do interesse público sobre o privado à luz das inovações introduzidas pela nova ordem constitucional de 1988 ". 381

Por outro ângulo de mirada, todavia, esta questão permanece problemática, vez que o consenso da ponderação como "solução universal",382 para a harmonização dos interesses em conflito no caso concreto certamente abre espaço para uma série de outras indagações que, neste capítulo, em face do debate doutrinário acerca do princípio da supremacia do interesse público sobre o particular no direito administrativo brasileiro, também passam a ganhar relevância.

\footnotetext{
381 in Maria Adelaide de Campos FRANCA. Supremacia do interesse público versus supremacia dos direitos individuais. in. Maria Sylvia Zanella DI PIETRO e Carlos Vinícius Alves RIBEIRO (coord.). Supremacia do interesse público e outros temas relevantes do direito administrativo. p. 169. Sem embargo, para exemplos de textos que expressamente clamam pela ponderação, no debate doutrinário acerca do princípio da supremacia do interesse público sobre o particular no direito administrativo brasileiro, ver: Carlos Eduardo Bergamini CUNHA. Discricionariedade administrativa e interesses públicos: superando a supremacia em busca da ponderação. in Fórum Administrativo. v. 11. n. 122. p. 9-21.; Gabriel de Araújo LIMA. Teoria da supremacia do interesse público: crise, contradições e incompatibilidade de seus fundamentos com a constituição federal. in A\&C - Revista de Direito Administrativo \& Constitucional, $\mathrm{n}^{\circ}$. 36. p. 123-153.; Carlos Henrique Costa LEITE. A interpretação da idéia de supremacia do interesse público sobre o privado no paradigma do Estado democrático de direito. in Revista Forense. v. 107. n. 414. p. 69-100.; entre outros.

${ }^{382}$ Referência à expressão invocada por Fernando Dias MENEZES de ALMEIDA, conforme colacionado acima; vide no quinto capítulo desta pesquisa, o tópico 5.4. retro.
} 
Considerando, pois, a tão debatida teoria de Robert ALEXY, segundo a qual a colisão de princípios ocorre na dimensão de peso, ${ }^{383}$ ou seja, numa dimensão em que a precedência condicionada do mandamento prevalecente é definida apenas em relação àquele caso específico, ${ }^{384}$ caberia, sem embargo, indagar: afinal, como saber qual princípio/valor/interesse é o mais importante diante das circunstâncias fáticas e jurídicas presentes em cada caso? Não haveria, também, muita subjetividade neste critério? E ainda, dois agentes públicos - ou dois julgadores -, diante das mesmas condições de fato e de direito, não poderiam chegar a diferentes conclusões quanto ao princípio merecedor da chamada precedência condicionada no caso concreto?

Na obra de Robert ALEXY, vale ressaltar, o recurso da ponderação/sopesamento justifica-se porque, em resumo, numa situação de conflito entre um interesse público e um interesse privado, “(...) nenhum desses interesses goza, em si mesmo, de precedência sobre o outro". ${ }^{385}$ Mesmo o princípio da dignidade da pessoa humana, para o autor, é preciso que se diga, “(...) constitui somente à primeira vista uma exceção a essa ideia”. 386

Pois bem, se é assim, forçosamente defluiria, portanto, concluir pela total e absoluta inexistência de hierarquia entre princípios/valores/interesses albergados no ordenamento jurídico? Dentro de uma visão sistêmica, com efeito, não existiriam conteúdos normativos mais ou menos importantes para o funcionamento do sistema de direito?

Neste ponto, sendo necessário manter o foco sobre o debate ora investigado, cumpre, vencendo a tentação do aprofundamento detido à referida teoria de Robert ALEXY, investigar, especificamente, o que pensam os doutrinadores brasileiros acerca dos questionamentos acima invocados. Por essa linha, destarte, o problema dimensionado por

\footnotetext{
${ }^{383}$ Cf. Robert ALEXY. Teoria dos direitos fundamentais. p. 94.

${ }^{384}$ Cf. Virgílio Afonso da SILVA. A constitucionalização do direito: os direitos fundamentais nas relações entre particulares. p. 34.

385 Robert ALEXY. Teoria dos direitos fundamentais. p. 97. Como diz Floriano Peixoto de Azevedo MARQUES NETO: “[o] peso diferencial entre os princípios a que alude Alexy não se configura em si. Depende do contexto em que um dado princípio é invocado. Ou seja: a densidade que faz um princípio jurídico prevalecer em relação a outro não pode ser tomada como definitiva, restando iminentemente conjuntural". in Floriano Peixoto de Azevedo MARQUES NETO. O conflito entre princípios constitucionais: breves pautas para sua solução. in Cadernos de direito constitucional e ciência política, $\mathrm{n}^{\circ}$. 10. p. 43.

${ }^{386}$ Robert ALEXY. Teoria dos direitos fundamentais. p. 97.
} 
tantas perguntas, para os fins visados por esta pesquisa nesta dimensão de análise, pode ser descrito da seguinte maneira:

Primeiramente, tem-se bastante claro que de acordo com o pensamento desenvolvido pela chamada doutrina administrativista tradicional, o sistema jurídico de direito público resta compreendido através de uma dinâmica normativa hierarquizada. Assim é que José CRETELLA JR. - de quem se possa pinçar, talvez, o exemplo mais ilustrativo deste entendimento -, repetindo o que já fora colacionado na primeira parte da presente dissertação, ${ }^{387}$ "não concebia o princípio da supremacia do interesse público sobre o particular senão como "matriz suprema orientadora" de qualquer construção publicística, da qual todos os outros postulados “(...) se afirmam como corolários ou escólios, dispostos em pontos mais baixos da pirâmide principiológica"”. Com isso, eis a centralidade donde promanaria, em lógica sistêmica, a supremacia do interesse público sobre o interesse particular dentro de um ordenamento chamado regime jurídico de direito público.

Ocorre que de outra banda, porém, com a emergência das inovações trazidas pela Constituição Federal de 1988 - que nas palavras de Luís Roberto BARROSO, “(...) foi capaz de promover, de maneira bem sucedida, a travessia do Estado brasileiro de um regime autoritário, intolerante e, por vezes, violento para um Estado democrático de direito",$-{ }^{388}$ deu-se vida definitiva ao ideário de positivação de um vetor de unidade e coerência para o resguardo normativo dos direitos fundamentais do homem, ${ }^{389}$ daí resultando, como já se sabe, a localização do princípio da dignidade da pessoa humana “(...) ante à topografia do Texto Constitucional Brasileiro, no qual fora erigido, por força de menção expressa do inciso terceiro do seu artigo inaugural, como um dos fundamentos do Estado Democrático de Direito".390

Pela dicção de Flávia PIOVESAN, “(...) é no princípio da dignidade da pessoa humana que a ordem jurídica encontra o seu próprio sentido, sendo seu ponto de partida e

\footnotetext{
${ }^{387}$ Consultar, no segundo capítulo desta pesquisa, o tópico 2.6. retro.

${ }^{388}$ Luís Roberto BARROSO. Neoconstitucionalismo e constitucionalização do direito (o triunfo tardio do direito constitucional no Brasil). in Revista Trimestral de Direito Público, ed. 44. p. 20.

${ }^{389}$ Cf. Murilo Ruiz FERRO. Princípio da dignidade da pessoa humana: o problema de um conceito. in Cadernos de iniciação científica, Faculdade de Direito de São Bernardo do Campo, n. 4. p. 96.

390 Murilo Ruiz FERRO. Princípio da dignidade da pessoa humana: o problema de um conceito. in Cadernos de iniciação científica, Faculdade de Direito de São Bernardo do Campo, n. 4. p. 96.
} 
seu ponto de chegada, para a hermenêutica constitucional contemporânea". ${ }^{391}$ Assim, posto ao quadro que emoldura a constitucionalização do direito, este princípio passa a ocupar o centro regedor de todo o sistema jurídico, conforme, nos termos aduzidos pela a própria autora, abaixo segue:

“(...) a dignidade da pessoa humana é princípio que unifica e centraliza todo o sistema normativo, assumindo especial prioridade. A dignidade humana simboliza, desse modo, verdadeiro super-princípio constitucional, a norma maior a orientar o constitucionalismo contemporâneo, nas esferas local e global, dotando-lhe de especial racionalidade, unidade e sentido". ${ }^{392}$

Sem prejuízo da lição ora transcrita, entretanto, não deixa de ser curioso perceber a existência de um descompasso teórico nos dizeres de autores que, embora utilizando a teoria de Robert ALEXY para inserir os princípios jurídicos na categoria de mandamentos de otimização, identificam o princípio da dignidade da pessoa humana, tal qual acima colacionado, como sendo a disposição máxima, central e fundamental de todo o sistema jurídico. ${ }^{393}$

E em relação ao debate aqui examinado, nota-se que alguns administrativistas também incorrem nesta contradição quando, para enaltecer o princípio da dignidade da pessoa humana, criticam o princípio da supremacia do interesse público sobre o particular, com a referida argumentação baseada na inexistência de hierarquia entre princípios jurídicos. ${ }^{394}$ Esses autores, como sintetiza Daniel Wunder HACHEM, "[s]e de um lado

\footnotetext{
${ }^{391}$ Flávia PIOVESAN. Direitos humanos e o direito constitucional internacional. p. 30.

${ }^{392}$ Flávia PIOVESAN. Direitos humanos e o direito constitucional internacional. p. 31.

393 Cuida-se, logicamente, do mesmo equívoco teórico abordado no capítulo anterior, especificamente, no tópico 5.3. retro.

394 Cf. Daniel Wunder HACHEM. Princípio constitucional da supremacia do interesse público. p. 264. Para alguns exemplos, sem embargo, esse tipo de contradição mostra-se presente nas seguintes publicações: Daniel SARMENTO. Interesses públicos vs. interesses privados na perspectiva da teoria e da filosofia constitucional. in Daniel SARMENTO (org.). Interesses públicos versus interesses privados:desconstruindo o princípio da supremacia do interesse público. p. 23-116.; Marco Aurélio Senko da HORA. A relativização da supremacia do interesse público em face do fundamento constitucional da dignidade da pessoa humana. in Revista do Tribunal Regional do Trabalho da $9^{a}$ Região. v. 36. n. 67. p. 631-657.; Marçal JUSTEN FILHO. $O$ direito administrativo de espetáculo. in Alexandre Santos de ARAGÃO; Floriano Peixoto de Azevedo MARQUES NETO (coord.). Direito administrativo e seus novos paradigmas. p. 65-86.; entre outros.
} 
questionam a possibilidade de afirmação da supremacia do interesse público, por outro defendem a supremacia da dignidade humana e dos direitos fundamentais". 395

Potenciais contradições à parte, sobreleva-se na doutrina publicista uma incompatibilidade - pelo menos, aparente - entre o princípio da supremacia do interesse público sobre o particular e o princípio da dignidade da pessoa humana. A polêmica é grandiosa e sintomáticas de sua repercussão no meio acadêmico são, por exemplo, os dizeres de Marco Aurélio Senko da HORA, ao asseverar que “(...) de forma diametralmente oposta do que muitos pensam e defendem, o vetor-orientador do direito administrativo é a dignidade da pessoa humana e não o da supremacia arbitrária e cega do interesse público", 396 de maneira que "(...) a destronação do princípio da supremacia do interesse público é imprescindível, devendo, pois, ser excluído do patamar hierárquico que é posto cotidianamente na práxis administrativa, visto que se evidencia intenso processo de personificação do direito administrativo". 397

Por essa aventada oposição de princípios jurídicos, o que de fato passa a ser questionado é a compatibilidade da supremacia do interesse público sobre o particular com o sistema normativo extraído do texto da constituição federal de 1988. Isto posto, faz-se necessário, ainda, ladear algumas outras passagens doutrinárias importantes para a investigação dos pontos de divergência contidos nesta dimensão de análise do debate.

\subsection{Do dilema principiológico ao efetivo problema da compatibilidade do princípio da supremacia do interesse público sobre o particular com a constituição federal de 1988}

Paulo Ricardo SCHIER problematiza este debate pressupondo “(...) $\boldsymbol{a}$ entronização do interesse público num pretenso patamar hierárquico superior àquele

\footnotetext{
${ }^{395}$ Daniel Wunder HACHEM. Princípio constitucional da supremacia do interesse público. p. 264.

396 Marco Aurélio Senko da HORA. A relativização da supremacia do interesse público em face do fundamento constitucional da dignidade da pessoa humana. in Revista do Tribunal Regional do Trabalho da $9^{a}$ Região. v. 36. n. 67. p. 639-640.

397 Marco Aurélio Senko da HORA. A relativização da supremacia do interesse público em face do fundamento constitucional da dignidade da pessoa humana. in Revista do Tribunal Regional do Trabalho da $9^{a}$ Região. v. 36. n. 67. p. 651.
} 
ocupado pelos direitos e liberdades individuais". ${ }^{398}$ Prossegue e, após o desenvolvimento de seu ensaio, constata que a inexata compreensão do que realmente sejam os princípios gerais de direito público faz com “(...) que a ideia de supremacia do interesse público sobre o privado funcione como verdadeira cláusula geral de restrição dos direitos, liberdades e garantias fundamentais, olvidando os seus limites e distorcendo todo o regime constitucional dos direitos fundamentais", 399

Certamente, o acima exposto não revela qualquer tipo de colocação doutrinária isolada, já que, filiando-se a mesma diretriz teórica, Gustavo BINENBOJM exara o seu posicionamento no sentido de que referida "ideia de supremacia de interesse público sobre o privado" “(...) não resiste à emergência do constitucionalismo e à consagração dos direitos fundamentais e da democracia como fundamentos de legitimidade e elementos estruturantes do Estado democrático de direito". ${ }^{400}$ E dele, por fim, também não irá destoar o pensamento de Marçal JUSTEN FILHO, com a declaração de que "[a] supremacia do interesse público somente é consagrada em Estados totalitários, que eliminam do ser humano a condição de sujeito de direito". ${ }^{401}$

De tal concepção, em suma, deriva o entendimento de que o princípio da supremacia do interesse público sobre o particular não encontra respaldo no sistema constitucional brasileiro. ${ }^{402}$

Das vozes contrárias a esta premissa, pode-se destacar a levantada por Maria Sylvia Zanella DI PIETRO, ${ }^{403}$ plenamente convicta de que este princípio, ao lado de outro,

\footnotetext{
${ }^{398}$ Paulo Ricardo SCHIER. Ensaio sobre a supremacia do interesse público sobre o privado e o regime jurídico dos direitos fundamentais. in Daniel SARMENTO (org.). Interesses públicos versus interesses privados:desconstruindo o princípio da supremacia do interesse público. p. 219.

399 Paulo Ricardo SCHIER. Ensaio sobre a supremacia do interesse público sobre o privado e o regime jurídico dos direitos fundamentais. in Daniel SARMENTO (org.). Interesses públicos versus interesses privados:desconstruindo o princípio da supremacia do interesse público. p. 241.

${ }^{400}$ Gustavo BINENBOJM. Uma teoria do direito administrativo: direitos fundamentais, democracia $e$ constitucionalização. p. 30.

401 Marçal JUSTEN FILHO. O direito administrativo de espetáculo. in Alexandre Santos de ARAGÃO; Floriano Peixoto de Azevedo MARQUES NETO (coord.). Direito administrativo e seus novos paradigmas. p. 79.

402 Talvez, a manifestação mais emblemática neste sentido seja a de Gustavo BINENBOJM, para quem, “[d]esta forma, verifica-se não ser possível extrair "o princípio da supremacia do interesse público" da análise do conjunto normativo constitucional, haja vista a ampla proteção dispensada aos interesses particulares, de tal maneira que aceitá-lo como norma-princípio significaria sucumbir à inconsistência sistêmica que representa e afrontar a constante busca pela unidade constitucional". in Gustavo BINENBOJM. Uma teoria do direito administrativo: direitos fundamentais, democracia e constitucionalização. p. 96.
} 
o da legalidade, ambos básicos do direito administrativo, não permaneceu estático no decurso do tempo. Para a autora, isso significa que a principiologia administrativista tem acompanhado as transformações do Estado até assumir nova feição no momento atual, ${ }^{404}$ daí cabendo constatar:

\begin{abstract}
“Assim como o princípio da legalidade saiu de sua fórmula rígida e formalista, própria do Estado legal e chegou a uma fórmula muito mais ampla que se ajusta ao Estado de Direito propriamente dito, também o princípio do interesse público começou como proposição adequada ao Estado liberal, não intervencionista (com o já assinalado cunho utilitarista) e assume feição diversa para adaptar-se ao Estado social e democrático de Direito, adotado na Constituição de 1988 ". 405
\end{abstract}

Por esta linha de raciocínio, Maria Sylvia Zanella DI PIETRO ainda observa que “(...) o direito administrativo nasceu justamente no período do Estado liberal, cuja preocupação maior era a de proteger os direitos individuais frente aos abusos do poder", ${ }^{406}$ razão pela qual, na esteira de seu pensar, “[o] princípio da supremacia do interesse público, ao contrário do que se afirma, não coloca em risco os direitos fundamentais do homem. Pelo contrário, ele os protege". 407

\footnotetext{
${ }^{403}$ E das vozes que a seguem quanto a este tema, podem ser mencionados: Luiz Fernando ROBERTO. Supremacia do interesse público sobre o privado: um panorama crítico da teoria de desconstrução do princípio. in Revista da Procuradoria Geral do Estado de São Paulo, Estudos em homenagem à professora Maria Sylvia Zanella Di Pietro. n. 71. p. 195-215.; Paulo Roberto Ferreira MOTTA. Direito administrativo direito da supremacia do interesse público. in Romeu Felipe BACELLAR FILHO; Daniel Wunder HACHEM (coord.). Direito administrativo e interesse público: estudos em homenagem ao professor Celso Antônio Bandeira de Mello. p. 221-238.; Gustavo Assed FERREIRA. A legitimidade do Estado e a supremacia do interesse público sobre o particular. in. Thiago MARRARA (org.). Princípios de direito administrativo: legalidade, segurança jurídica, impessoalidade, publicidade, motivação, eficiência, moralidade, razoabilidade, interesse público. p. 441-451.; entre outros.

${ }^{404}$ Cf. Maria Sylvia Zanella DI PIETRO. O princípio da supremacia do interesse público: sobrevivência diante dos ideais do neoliberalismo. in. Maria Sylvia Zanella DI PIETRO e Carlos Vinícius Alves RIBEIRO (coord.). Supremacia do interesse público e outros temas relevantes do direito administrativo. p. 93.

${ }^{405}$ Maria Sylvia Zanella DI PIETRO. O princípio da supremacia do interesse público: sobrevivência diante dos ideais do neoliberalismo. in. Maria Sylvia Zanella DI PIETRO e Carlos Vinícius Alves RIBEIRO (coord.). Supremacia do interesse público e outros temas relevantes do direito administrativo. p. 93.

${ }^{406}$ Maria Sylvia Zanella DI PIETRO. O princípio da supremacia do interesse público: sobrevivência diante dos ideais do neoliberalismo. in. Maria Sylvia Zanella DI PIETRO e Carlos Vinícius Alves RIBEIRO (coord.). Supremacia do interesse público e outros temas relevantes do direito administrativo. p. 99.

${ }^{407}$ Maria Sylvia Zanella DI PIETRO. O princípio da supremacia do interesse público: sobrevivência diante dos ideais do neoliberalismo. in. Maria Sylvia Zanella DI PIETRO e Carlos Vinícius Alves RIBEIRO (coord.). Supremacia do interesse público e outros temas relevantes do direito administrativo. p. 99.
} 
É, sem embargo, a mesma opinião expressada por Regina Maria Macedo Nery FERRARI, a partir da seguinte lição:

"Não procede o argumento dos que negam a supremacia do interesse público a partir do necessário respeito aos direitos fundamentais, pois, o exercício do Poder Público só tem sentido, só adquire consistência, quando realiza a dignidade da pessoa humana, já que seu fim se condensa na satisfação, no atendimento das necessidades do ser humano.

\section{$(\ldots)$}

Nenhum interesse pode ser considerado público se levar ao sacrifício dos valores e dos direitos fundamentais. A preponderância do interesse público exige que todos os esforços sejam empregados, com a maior eficiência possível, para o atendimento do indivíduo.

\section{(...)}

A administração só se legitima como instrumento de realização dos interesses públicos, e estes só se conceituam à luz da dignidade da pessoa humana, vale dizer, o Estado pode não ser o único titular do interesse público, já que é possível pensar em interesses públicos não estatais, mas existe um vínculo, indissociável, entre o Estado e a satisfação do interesse público e entre este e o respeito pela dignidade da pessoa humana". ${ }^{408}$

Neste ponto, interessante notar a percepção obtida por Lívia Deprá Camargo SULZBACH, por ocasião do seu cotejo acerca dos posicionamentos doutrinários referentes a este aspecto específico do debate, verificando que “(...) na verdade, os defensores do princípio da supremacia do interesse público também o interpretam como tendo sua aplicação limitada pelas demais normas constitucionais, dentre elas, os direitos fundamentais", ${ }^{409}$ por isso, “(...) constata-se que a concepção do princípio da supremacia do interesse público como um princípio ilimitado não vige na atualidade". ${ }^{410}$

\footnotetext{
408 Regina Maria Macedo Nery FERRARI. Reserva do possível, direitos fundamentais sociais e a supremacia do interesse público. in Romeu Felipe BACELLAR FILHO; Daniel Wunder HACHEM (coord.), Direito administrativo e interesse público: estudos em homenagem ao professor Celso Antônio Bandeira de Mello. p. 297.

${ }^{409}$ Lívia Deprá Camargo SULZBACH. A responsabilidade subsidiária da administração pública na terceirização de serviços - princípio da supremacia do interesse público x dignidade da pessoa humana?
} 
Trata-se de inferência encontrada também no trabalho de Daniel Wunder HACHEM que, aliás, vai além, pois, após realçar que "[n]ão há que sustente - por óbvia carência de fundamentos normativos - que o princípio da supremacia do interesse público legitima o administrador público a restringir direitos fundamentais sem supedâneo na lei ou na Constituição", 411 assinala que "[t]ais autores criticam, portanto, uma posição que não é compartilhada pelos autores que advogam a existência do princípio da supremacia do interesse público". 412

De fato, parece extremamente óbvio que nenhum jurista esteja a propagar a violação da teleologia democrática trazida pela vigente constituição federal, nela devidamente compreendida a importância indiscutível do princípio da dignidade da pessoa humana e, por extensão, da tutela projetada sobre os direitos fundamentais do homem. Dentro desta obviedade, contudo, é preciso investigar os motivos pelos quais a ideia de interesse público tem dividido a opinião dos doutrinadores administrativistas nos dias atuais e a principal indagação neste sentido, como já se pode perceber, é: na presente sistemática constitucional, o princípio da supremacia do interesse público sobre o particular constitui, verdadeiramente, um instrumento de proteção ou de ameaça aos direitos fundamentais do homem?

O enfrentamento desta questão, nos termos aqui parametrizados, implica em saber como os doutrinadores administrativistas brasileiros andam debatendo os lineamentos conceituais acerca das noções de "interesses públicos" e "interesses privados" diante de uma realidade prática bastante complexa, já reconhecida por todos na teoria, qual seja a da contraposição destas duas ordens de interesses na chamada sociedade pluriclasse contemporânea. $^{413}$

Repercussões do julgamento da ADC n. 16 pelo STF na súmula n. 331 do TST. in LTr: Revista Legislação do Trabalho. v. 76. n. 6. p. 736.

${ }^{410}$ Lívia Deprá Camargo SULZBACH. A responsabilidade subsidiária da administração pública na terceirização de serviços - princípio da supremacia do interesse público $x$ dignidade da pessoa humana? Repercussões do julgamento da ADC n. 16 pelo STF na súmula n. 331 do TST. in LTr: Revista Legislação do Trabalho. v. 76. n. 6. p. 736.

${ }^{411}$ Daniel Wunder HACHEM. Princípio constitucional da supremacia do interesse público. p. 338.

${ }^{412}$ Daniel Wunder HACHEM. Princípio constitucional da supremacia do interesse público. p. 338.

${ }^{413}$ Sobre este consenso, consultar no quarto capítulo desta pesquisa, os tópicos 4.2. e 4.4. retro. 


\title{
6.3. Interesses públicos e privados na sociedade pluriclasse
} contemporânea: notas sobre a indispensável busca do equilíbrio na discussão, no direito administrativo brasileiro, acerca da relação existente entre a atuação estatal e a preservação dos direitos fundamentais do homem

Com o intuito de demonstrar o caráter potencialmente antidemocrático do princípio da supremacia do interesse público sobre o particular, Alexandre Santos de ARAGÃO menciona dois exemplos através dos quais o cenário jurisprudencial estadunidense teria consagrado o arbítrio estatal em detrimento da liberdade do cidadão. Pelas palavras do autor, os casos são assim apresentados:

\begin{abstract}
"A sobrepujança na ponderação de interesses de argumentos retóricos em prol do "interesse público" ou de seus subvalores já possibilitou nos EUA fortes restrições à liberdade de manifestação de ideias que fossem consideradas esquerdistas (Dennis v. United States), ou que cidadãos norte-americanos de origem japonesa ficassem confinados em campos de concentração durante a Segunda Guerra Mundial (Korematsu v. United States)". 414
\end{abstract}

Prosseguindo, em análise sucinta e objetiva dos julgamentos trazidos ao debate, Alexandre Santos de ARAGÃO comenta que "[o] fundamento dessas decisões foi que, na ponderação entre os valores da segurança nacional (interesse público) e os da liberdade, deveriam prevalecer aqueles em detrimento desses". 415

Cuida-se de análise expressamente contestada por Daniel Wunder HACHEM, para quem "[t]ais casos não encontram guarida, de forma alguma no princípio da supremacia do interesse público", 416 sobretudo porque “(...) os direitos fundamentais compõem o núcleo conceitual do interesse público, de sorte que tanto a violação da

\footnotetext{
${ }^{414}$ Alexandre Santos de ARAGÃO. A "supremacia,do interesse público" no advento do Estado de Direito e na hermenêutica do direito público contemporâneo. in Daniel SARMENTO (org.). Interesses públicos versus interesses privados:desconstruindo o princípio da supremacia do interesse público. p. 7.

${ }^{415}$ Alexandre Santos de ARAGÃO. A "supremacia,do interesse público" no advento do Estado de Direito e na hermenêutica do direito público contemporâneo. in Daniel SARMENTO (org.). Interesses públicos versus interesses privados:desconstruindo o princípio da supremacia do interesse público. p. 7.

${ }^{416}$ Daniel Wunder HACHEM. Princípio constitucional da supremacia do interesse público. p. 342.
} 
liberdade de expressão quanto a ofensa à liberdade de locomoção importariam agressão ao interesse público". ${ }^{417}$ Desta feita, sua discordância é concluída nos seguintes termos:

\begin{abstract}
"Nas situações narradas, a restrição promovida acabou por aniquilar o conteúdo essencial dos direitos fundamentais, resultando em uma limitação irrazoável e desproporcional, atentatória contra o ordenamento jurídico. Se o interesse público deve ser encontrado no próprio sistema normativo, e esse mesmo sistema salvaguarda os princípios da proporcionalidade e da razoabilidade, a restrição excessiva de um direito, que importe a sua eliminação, jamais poderá estar de acordo com o interesse público". 418
\end{abstract}

Uma vez mais - agora, nesta última dimensão de análise -, o debate confirma a “problematização desenhada" no capítulo inaugural da presente dissertação, ${ }^{419}$ pois bem evidencia que a divergência travada por todos os juristas até aqui citados termina por versar sobre determinado fundamento de direito, ou melhor, sobre o entendimento teórico que cada um desses juristas possui acerca deste fundamento, especificamente, neste caso, a saber: tudo o quanto possa fundamentar uma noção conceitual de direitos fundamentais do homem - relacionando-a, também, com as noções conceituais de interesses públicos e interesses privados -. E neste passo, aliás, qual seria a melhor forma de acomodar estes direitos dentro do paradoxo democrático que se extrema nas variáveis da autoridade estatal e da liberdade individual ? $^{420}$ Parece claro, afinal, que toda vez que o sistema - aqui entendido com um todo, isto é, pela integração dos aspectos econômico, político, jurídico e social - entra em desequilíbrio, pendendo excessivamente para um lado ou para outro, os chamados direitos fundamentais do homem acabam sendo inexoravelmente violados.

Por uma linha de abordagem desenvolvida fora deste debate, mas paralelamente a ele, José Eduardo FARIA observa que a relação entre os interesses público e privado

\footnotetext{
${ }^{417}$ Daniel Wunder HACHEM. Princípio constitucional da supremacia do interesse público. p. 342.

${ }^{418}$ Daniel Wunder HACHEM. Princípio constitucional da supremacia do interesse público. p. 342.

${ }^{419}$ Consultar o primeiro capítulo desta pesquisa, retro.

${ }^{420}$ Esta questão, aqui arrolada em plano conceitual, já fora transposta a um caso prático por Carlos Ari SUNDFELD, ocasião em que o jurista, para tratar do "problema da vigilância epidemiológica frente aos direitos constitucionais" - e primeiramente considerando que tal problema "(...) se insere em um dos capítulos mais apaixonantes do direito público: o das tensões entre a autoridade e a liberdade" - então questiona: "[c]omo se devem interpretar os mandamentos constitucionais de proteção da liberdade individual frente à exigência, igualmente constitucional, de proteção e defesa da saúde pública?" in Carlos Ari SUNDFELD. Interesse público em sentido mínimo e sentido forte: o problema da vigilância epidemiológica frente aos direitos constitucionais. in Revista Interesse Público, n. ${ }^{\circ} 28$. p. 29.
} 
constitui uma das questões centrais da filosofia política e jurídica moderna. ${ }^{421}$ Passo adiante, observa também que, a modo de definição geral, “(...) o interesse público tem sido entendido como padrão destinado a servir como critério para balizar, fundamentar e legitimar as decisões governamentais", ${ }^{422}$ sendo que "[n]os países de tradição democrática, em que tais decisões são tomadas com base na "regra de maioria", esse padrão de valor tem sido, muitas vezes, associado à noção de "justiça" - evidentemente, numa perspectiva de caráter formal". 423

Para o autor, ainda, essa associação necessitaria, idealmente, conciliar dois princípios básicos: o primeiro, que “(...) enfatiza a ampla liberdade de cada cidadão desde que ela seja compatível com a ampla liberdade dos demais cidadãos”; ${ }^{424}$ e o segundo, “(...) que recomenda a redução das desigualdades econômicas gritantes, tendo em vista a consecução de um certo equilíbrio social". ${ }^{425}$

Assim, no plano ideal, uma decisão política traduziria o interesse público quando beneficiasse toda a coletividade, “(...) se não imediatamente, pelo menos a médio e longo prazo, e quer (ou não) todos a identificassem como "boa" para si num primeiro momento". ${ }^{426}$ Com efeito, uma ação na perspectiva do interesse público seria, segundo José Eduardo FARIA, aquela possível de ser justificada “(...) por ir ao encontro das diferentes aspirações individuais e cuja aprovação se dá com base num consenso quanto aos procedimentos, ou seja, quanto às normas gerais e universais que orientam os tipos de fins que podem ser atingidos numa dada sociedade pluralista". ${ }^{427}$

O problema, quando se fala em sociedade pluralista, ocorre justamente quando a lógica característica desta pluralidade de interesses resta convertida em conflitos “(...) entre alternativas excludentes que, para serem equacionados ou dirimidos, exigem a imposição de uma decisão política com base na "violência legítima" do Estado". 428 Por outras palavras, problemática é, em última análise, a busca do “(...) adequado equilíbrio entre o

\footnotetext{
${ }^{421}$ Cf. José Eduardo FARIA. Direito e economia na democratização brasileira. p. 63-64.

${ }^{422}$ José Eduardo FARIA. Direito e economia na democratização brasileira. p. 65.

${ }^{423}$ José Eduardo FARIA. Direito e economia na democratização brasileira. p. 65.

${ }^{424}$ José Eduardo FARIA. Direito e economia na democratização brasileira. p. 65.

${ }^{425}$ José Eduardo FARIA. Direito e economia na democratização brasileira. p. 65.

${ }^{426}$ José Eduardo FARIA. Direito e economia na democratização brasileira. p. 66.

${ }^{427}$ José Eduardo FARIA. Direito e economia na democratização brasileira. p. 66.

${ }^{428}$ José Eduardo FARIA. Direito e economia na democratização brasileira. p. 67.
} 
bem público e o direito dos indivíduos de exercer o livre arbítrio e ver assegurado o respeito a seus interesses particulares". ${ }^{429}$

Neste sentido, não se olvida que sem a mínima atuação estatal não há como cogitar o equilíbrio de qualquer jogo de interesses e isso implica, por conseguinte, na própria dificuldade de se saber quais interesses encontram-se tutelados pela expressão “interesse público”. Há nítida dificuldade, pois, como exemplifica, a título ilustração, José Eduardo FARIA, a própria evolução histórica do século XVIII até os dias atuais tem registrado que “(...) os indivíduos muitas vezes reivindicam a redução ao mínimo de seus impostos, enquanto a realização de certas funções indispensáveis por parte do poder público exige uma substancial majoração da carga tributária"; ${ }^{430}$ nada obstante, o autor oferece também outro exemplo ilustrativo, este demonstrando que, muitas vezes, os livres empreendedores “(...) costumam formar cartéis, efetuando acordos para elevar artificialmente o preço de seus bens e serviços e assim subvertendo o livre jogo de mercado - enquanto o interesse público seria melhor atendido caso houvesse uma efetiva concorrência entre eles". ${ }^{431}$

É provavelmente diante deste contexto que Maria Sylvia Zanella DI PIETRO tenha asseverado que o real objetivo que motiva as teorias de desconstrução do princípio da supremacia do interesse público sobre o particular seja o de "fazer prevalecer o interesse econômico sobre os outros igualmente protegidos pela Constituição". ${ }^{432}$ Mas isso não

\footnotetext{
${ }^{429}$ José Eduardo FARIA. Direito e economia na democratização brasileira. p. 68.

${ }^{430}$ José Eduardo FARIA. Direito e economia na democratização brasileira. p. 71.

431 José Eduardo FARIA. Direito e economia na democratização brasileira. p. 71. No entender de Irene Patrícia NOHARA: “[é] óbvio que os setores privados não colocarão, via de regra, sponte propria interesses coletivos acima de seus interesses particulares. Basta refletir que a finalidade lucrativa é o intuito principal da lógica do mercado, que, via de regra, não se movimenta como o terceiro setor. Não se pode negar, portanto, que se não houver uma instância legítima e apta a impor regras com caráter coercitivo, não se pode esperar que tal respeito ocorra espontaneamente". in Irene Patrícia NOHARA. Reflexões críticas acerca da tentativa de desconstrução do sentido da supremacia do interesse público no direito administrativo. in. Maria Sylvia Zanella DI PIETRO e Carlos Vinícius Alves RIBEIRO (coord.). Supremacia do interesse público e outros temas relevantes do direito administrativo. p. 124.

${ }^{432}$ Maria Sylvia Zanella DI PIETRO. O princípio da supremacia do interesse público: sobrevivência diante dos ideais do neoliberalismo. in. Maria Sylvia Zanella DI PIETRO e Carlos Vinícius Alves RIBEIRO (coord.). Supremacia do interesse público e outros temas relevantes do direito administrativo. p. 85. Neste contexto, o que acaba sendo discutido, na verdade, é a questão da função ideológica do neoliberalismo neste debate. Apesar de poucos autores enfrentarem esta questão, é possível citar, no mesmo sentido defendido por Maria Sylvia Zanella DI PIETRO, Irene Patrícia NOHARA. Reflexões críticas acerca da tentativa de desconstrução do sentido da supremacia do interesse público no direito administrativo. in. Maria Sylvia Zanella DI PIETRO e Carlos Vinícius Alves RIBEIRO (coord.). Supremacia do interesse público e outros temas relevantes do direito administrativo. p. 120-154.; e Gustavo Assed FERREIRA. A legitimidade do Estado e a supremacia do interesse público sobre o particular. in. Thiago MARRARA (org.). Princípios de
} 
significa que o ideal equilíbrio de interesses também não seja dificultado pela via oposta, isto é, pela atuação estatal além do estritamente necessário, ou, nas palavras de Floriano Peixoto de Azevedo MARQUES NETO, pela sedimentação do paradigma autoritário da esfera pública - ainda que, atualmente, em vias de erosão ${ }^{433}-$.

Para Floriano Peixoto de Azevedo MARQUES NETO, basicamente, "[c]omo o interesse público justificador da ação estatal é aberto, (...) cabe ao governante decidir, a cada situação, o que vem a ser o interesse público. Logo, tal paradigma confere à autoridade uma margem amplíssima de liberdade para intervir na esfera privada". ${ }^{434}$ Desta feita, ao que parece, o maior empecilho deste paradigma residiria na ideia da exclusividade estatal para a consecução do interesse público:

"Se à esfera pública cabe exclusivamente a consecução do interesse público, se contra esse não podem ser opostos interesses privados e se a determinação concreta do interesse público compete exclusiva e unilateralmente à autoridade, temos construído um paradigma pelo qual o Estado poderia intervir em qualquer seara da esfera privada, a mercê da vontade do governante de turno. E tudo como se estivéssemos a consagrar o interesse de todos". ${ }^{435}$

Por esta via, assim, a situação também seria de desequilíbrio, pois, novamente com base nos dizeres do autor, “[q]uanto mais frágil a esfera privada, mais a esfera pública avulta, intervindo em todos os campos. E quanto mais houver intervenção, mais fraca se

direito administrativo: legalidade, segurança jurídica, impessoalidade, publicidade, motivação, eficiência, moralidade, razoabilidade, interesse público. p. 441-451. Já em sentido contrário, posicionam-se expressamente: Carlos Eduardo Bergamini CUNHA. Discricionariedade administrativa e interesses públicos: superando a supremacia em busca da ponderação. in Fórum Administrativo. v. 11. n. 122. p. 921.; e .; Gabriel de Araújo LIMA. Teoria da supremacia do interesse público: crise, contradições e incompatibilidade de seus fundamentos com a constituição federal. in A\&C - Revista de Direito Administrativo \& Constitucional, $\mathrm{n}^{\circ}$. 36. p. 123-153.

${ }^{433}$ Cf. Floriano Peixoto de Azevedo MARQUES NETO. Interesses públicos e privados na atividade estatal de regulação. in. Thiago MARRARA (org.). Princípios de direito administrativo: legalidade, segurança jurídica, impessoalidade, publicidade, motivação, eficiência, moralidade, razoabilidade, interesse público. p. 428-429.

${ }^{434}$ Floriano Peixoto de Azevedo MARQUES NETO. Interesses públicos e privados na atividade estatal de regulação. in. Thiago MARRARA (org.). Princípios de direito administrativo: legalidade, segurança jurídica, impessoalidade, publicidade, motivação, eficiência, moralidade, razoabilidade, interesse público. p. 428.

${ }^{435}$ Floriano Peixoto de Azevedo MARQUES NETO. Interesses públicos e privados na atividade estatal de regulação. in. Thiago MARRARA (org.). Princípios de direito administrativo: legalidade, segurança jurídica, impessoalidade, publicidade, motivação, eficiência, moralidade, razoabilidade, interesse público. p. 428-429. 
tornará a esfera privada, pois (...) não existe ingerência estatal sem redução da e na esfera de autonomia dos indivíduos". 436

De qualquer forma, voltando ao cerne da divergência teórica ora apresentada, resta, de certa forma evidente, que na aferição da chamada medida ideal de intervenção estatal diante da complexidade da sociedade pluriclasse, muitas vezes torna-se difícil dizer o que é interesse exclusivamente privado e o que é interesse exclusivamente público. E dessa dificuldade decorrerá outra: a de se saber, nesta esteira, se os interesses públicos também podem ser reconhecidos na seara dos direitos fundamentais. Diante disso, faz-se necessário, então, estabelecer um paralelo entre esta questão e a chamada teoria dos direitos fundamentais do homem, discutida no âmbito do direito constitucional.

Este caminho, trilhado no tópico seguinte, ajudará a entender o diálogo travado pelos doutrinadores administrativistas brasileiros, esboçando pontos convergentes de entendimento também quanto a este último aspecto do debate ora investigado.

\subsection{Análise do diálogo travado pelos doutrinadores administrativistas brasileiros especificamente quanto ao princípio da supremacia do interesse público sobre o particular à luz da teoria dos direitos fundamentais do homem}

A acomodação dos direitos fundamentais do homem junto ao sistema democrático que, como já dito, deve sempre manter em equilíbrio as variáveis da autoridade estatal e da liberdade individual pode ser muito bem compreendida, na linguagem do direito constitucional, através da conhecida teoria que classifica tais direitos em gerações ou dimensões históricas de surgimento.

Num apertado resumo desta divisão teórica, rapidamente, coloca-se em destaque que os direitos fundamentais de primeira geração são aqueles propriamente relativos aos indivíduos: os chamados direitos de liberdade, porquanto oponíveis ao Estado e, desta

\footnotetext{
${ }^{436}$ Floriano Peixoto de Azevedo MARQUES NETO. Interesses públicos e privados na atividade estatal de regulação. in. Thiago MARRARA (org.). Princípios de direito administrativo: legalidade, segurança jurídica, impessoalidade, publicidade, motivação, eficiência, moralidade, razoabilidade, interesse público. p. 429.
} 
forma, convergentes, sem maiores discussões, à noção de interesses privados. Prosseguindo, é sabido que esses diferem, mas não são incompatíveis com os direitos fundamentais de segunda geração, que tratam dos chamados direitos sociais, sobretudo, em prestígio ao princípio da igualdade e por isso encontram-se mais próximos dos interesses da coletividade ou da noção básica de interesse público.

Sob o aspecto de uma leitura evolutiva, cabe perceber, ainda, que os direitos fundamentais de segunda geração - os direitos sociais - são vistos como complementos necessários àqueles que, no decorrer da história constitucional geral, foram primeiramente reconhecidos - os direitos individuais -. É neste sentido, pois, que Paulo BONAVIDES se manifesta:

\begin{abstract}
"Os direitos sociais fizeram nascer a consciência de que tão importante quanto salvaguardar o indivíduo, conforme ocorreria na concepção clássica dos direitos de liberdade, era proteger a instituição, uma realidade social muito mais rica e aberta à participação criativa e à valoração da personalidade que o quadro tradicional da solidão individualista, onde se formara o culto liberal do homem abstrato e insulado, sem a densidade dos valores existenciais, aqueles que unicamente o social proporciona em toda a plenitude". ${ }^{437}$
\end{abstract}

Com efeito, tal como numa síntese histórico-dialética, importa também notar o surgimento dos direitos fundamentais de terceira geração - alinhados com os ideais de fraternidade e solidariedade -, para tutelar - e conciliar - questões próprias das sociedades pluralistas, como a questão do direito ao desenvolvimento ou a questão do direito ao meio ambiente equilibrado, que dizem respeito tanto à figura do Estado quanto a dos indivíduos, numa conformação, como já se sabe, de interesses difusos e coletivos.

Não ignorando que hoje o debate dos constitucionalistas acerca da teoria dos direitos fundamentais do homem alcança, extensivamente, a consideração de direitos de quarta e também de quinta geração, ${ }^{438}$ é preciso, dentro do que busca a presente pesquisa, apenas realçar como os direitos fundamentais do homem podem - e devem - flutuar tanto na órbita dos interesses públicos como na dos interesses privados.

\footnotetext{
${ }^{437}$ Paulo BONAVIDES. Curso de direito constitucional. p. 565.

${ }^{438}$ Ver por todos, neste sentido, Paulo BONAVIDES. Curso de direito constitucional. p. 570-593.
} 
Tal realce nem demandaria maiores considerações não fosse a sugestão, por vezes até insistente, entre alguns doutrinadores administrativistas, de que são os interesses privados - quando em confronto com os interesses públicos - que são reconhecidos como direitos fundamentais pela constituição federal de 1988. ${ }^{439}$ Neste ponto, mostra-se pertinente a análise de Marcelo FIGUEIREDO, no sentido de que o “(...) princípio da supremacia do interesse público sobre o interesse privado, em uma ordem constitucional democrática, não pode ser visto como um "simples" (sic) antagonismo entre o interesse individual e o interesse público, do qual decorra". ${ }^{440}$

Verifica-se que o "simples antagonismo", como diz o autor, de fato pode corroborar com o desenvolvimento de uma lógica dogmática radicalmente bipolar, isto é, sem espaços de matização para a racionalidade jurídica e, por conseguinte, geradora até de um certo maniqueísmo operante no pensamento dos juristas, pois, no limite, ao menos hipoteticamente, esta divisão inflexível pode servir de base para que se diga que todo interesse considerado público seja verdadeiramente um interesse subordinado apenas à autoridade do Estado e portanto, tido como um interesse mau; ao passo que, pelo mesmo raciocínio, todo interesse considerado particular seja um interesse associado exclusivamente à liberdade do indivíduo e por isso sempre visto como um interesse bom. ${ }^{441}$

\footnotetext{
${ }^{439}$ Cf. Gustavo BINENBOJM. Uma teoria do direito administrativo: direitos fundamentais, democracia $e$ constitucionalização. p. 97.

${ }^{440}$ Marcelo FIGUEIREDO. Breve síntese da polêmica em torno do conceito de interesse público e sua supremacia: tese consistente ou devaneios doutrinários? in. Thiago MARRARA (org.). Princípios de direito administrativo:legalidade, segurança jurídica, impessoalidade, publicidade, motivação, eficiência, moralidade, razoabilidade, interesse público. p. 414.

${ }^{441}$ Não se pode deixar de destacar, contudo, que alguns trabalhos também são encontrados na direção oposta ao desta concepção de antagonismo absoluto de interesses ora relatado. É o caso, por exemplo de Angela Cassia COSTALDELLO, pugnando pela "complementaridade necessária entre os interesses público e privado" in Angela Cassia COSTALDELLO. A supremacia do interesse público e a cidade - a aproximação essencial para a efetividade dos direitos fundamentais. in Romeu Felipe BACELLAR FILHO; Daniel Wunder HACHEM (coord.). Direito administrativo e interesse público: estudos em homenagem ao professor Celso Antônio Bandeira de Mello. p. 239-265.; de Raquel Dias da SILVEIRA, que parece enxergar na noção de bem comum o elo entre o interesse público e a dignidade da pessoa humana. Cf. Raquel Dias da SILVEIRA. Princípio da supremacia do interesse público como fundamento das relações de trabalho entre servidores públicos e Estado. in Romeu Felipe BACELLAR FILHO; Daniel Wunder HACHEM (coord.). Direito administrativo e interesse público: estudos em homenagem ao professor Celso Antônio Bandeira de Mello. p. 347-375.; e por fim, de Zuenir de Oliveira NEVES, ao sustentar que "[a] proeminência dos direitos fundamentais no constitucionalismo contemporâneo, porque atribuiu nova roupagem ao conceito de interesse público, fez com que este se aproximasse mais da idéia de bem comum, (...) abordada na perspectiva aristotélico-tomista, segundo a qual o todo e suas partes perseguem o mesmo fim, a felicidade". in Zuenir de Oliveira NEVES. Por uma releitura da supremacia do interesse público no contexto do Estado democrático de direito. in Fórum Administrativo. v. 11. n. 121. p. 47.
} 
Todavia, em contrabalanço também são encontradas algumas posições mais ponderadas, ${ }^{442}$ como a de Alice Gonzalez BORGES, que em sua própria perquirição teórica do que seria o "interesse público digno de supremacia", ${ }^{443}$ sustenta que o texto constitucional alçou a dignidade da pessoa humana, bem como toda a declaração de direitos e garantias fundamentais ao “(...) grau mais elevado possível de interesses públicos". ${ }^{444}$ A autora recebe a companhia de Iuri Mattos de CARVALHO, este notando, em conformidade com as ideias acima desenvolvidas, “(...) que a Constituição Federal reconhece o status de direitos fundamentais a alguns interesses coletivos e direitos individuais", 445 de tal sorte que "(...) a definição do interesse público precisa reafirmar a vinculação de atuação administrativa aos direitos fundamentais, ao momento em que favorece o processo de constitucionalização do Direito Administrativo". 446

Nesta senda, mesmo Luís Roberto BARROSO, notoriamente ligado à bandeira neoconstitucionalista, reconhece o entrelaçamento dos interesses públicos com os direitos fundamentais do homem em diversas passagens de seu pensamento, ora quando afirma que o interesse público se realiza “(...) mesmo quando o beneficiário for uma única pessoa privada", ${ }^{447}$ ora quando define que o interesse público é supremo não somente por não ser passível de ponderação, mas por constituir, ao lado da dignidade da pessoa humana, o próprio parâmetro de tudo o que deva ser ponderado juridicamente, nos termos da constituição federal. ${ }^{448}$ Suas proposições, destarte, chamam a atenção de Daniel SARMENTO que, no exame destas, adverte que “(...) na substância, ele [Luís Roberto

\footnotetext{
${ }^{442}$ Não estou a utilizar a expressão "mais ponderadas" em sentido de adjetivação subjetiva, que poderia ser compreendido como sinônimo de "mais sensatas", por exemplo. Aqui, a expressão "mais ponderadas" deve ser lida como contraposta a "posições mais radicais", ou seja, a posições de autores que, com maior rigor, potencialmente, consideram que apenas os interesses privados são reconhecidos como direitos fundamentais na constituição federal de 1988.

${ }^{443}$ Cf. Alice Gonzalez BORGES. Supremacia do interesse público: desconstrução ou reconstrução? in Revista Interesse Público, n. ${ }^{\circ}$ 37. p. 35.

${ }^{444}$ Alice Gonzalez BORGES. Supremacia do interesse público: desconstrução ou reconstrução? in Revista Interesse Público, n. ${ }^{\circ}$ 37. p. 47.

${ }^{445}$ Iuri Mattos de CARVALHO. O princípio da supremacia do interesse público sobre o privado: parâmetros para uma reconstrução. in Revista Diálogo Jurídico. $\mathrm{n}^{\circ} .16$.

${ }^{446}$ Iuri Mattos de CARVALHO. O princípio da supremacia do interesse público sobre o privado: parâmetros para uma reconstrução. in Revista Diálogo Jurídico. $\mathrm{n}^{\circ} .16$.

${ }^{447}$ Luís Roberto BARROSO. Prefácio: o Estado contemporâneo, os direitos fundamentais e a redefinição da supremacia do interesse público. in Daniel SARMENTO (org.). Interesses públicos versus interesses privados:desconstruindo o princípio da supremacia do interesse público. p. xiv.

${ }^{448}$ Cf. Luís Roberto BARROSO. Prefácio: o Estado contemporâneo, os direitos fundamentais e a redefinição da supremacia do interesse público. in Daniel SARMENTO (org.). Interesses públicos versus interesses privados:desconstruindo o princípio da supremacia do interesse público. $\mathrm{p} . \mathrm{xv}-\mathrm{xvi}$.
} 
BARROSO] não discorda da tese (...), no sentido de que os interesses da coletividade não prevalecem incondicionalmente sobre os interesses individuais". ${ }^{449}$ Acontece que, mais uma vez, tendo em vista os registros de Maria Sylvia Zanella DI PIETRO, objetivamente lembrando que “(...) a ideia de que o interesse público sempre, em qualquer situação, prevalece sobre o particular jamais teve aplicação", 450 pois, “(...) se assim fosse, realmente não haveria como garantir os direitos individuais", 451 não se pode deixar de constatar, assim como o fez Daniel Wunder HACHEM, que neste sentido, a supremacia do interesse público sobre o particular tem sido objeto de uma divergência teórica nitidamente calcada em fundamentações doutrinárias que, na verdade, nunca foram aventadas por aqueles que defendem este princípio. ${ }^{452}$

Existe, portanto, um último consenso - bastante óbvio, aliás, como já visto - a ser extraído de tudo o que fora abordado nesta dimensão de análise: a concordância doutrinária geral - "mesmo que por palavras discordantes" - de que com fulcro na sistemática constitucional, em que nem os interesses coletivos nem os individuais são absolutos, irrestritos ou ilimitados, os valores da dignidade da pessoa humana e dos direitos fundamentais do homem - vez que presentes nestas duas ordens de interesses ora mencionadas - terminam por traduzir os ideais que, sem dúvidas, consubstanciam a formulação conceitual do chamado interesse público digno de supremacia e centralidade no ordenamento jurídico, viva na mente de qualquer administrativista brasileiro desconsiderando quem possa, eventualmente, sustentar que interesses públicos são interesses exclusivamente estatais e que, desta forma, em nada dizem respeito aos seres humanos; colocação esta que, salvo engano, pareceria refutar a própria razão do direito -.

\footnotetext{
449 Daniel SARMENTO. Supremacia do interesse público? As colisões entre direitos fundamentais e interesses da coletividade. in Alexandre Santos de ARAGÃO; Floriano Peixoto de Azevedo MARQUES NETO (coord.). Direito administrativo e seus novos paradigmas. p. 141.

${ }^{450}$ Maria Sylvia Zanella DI PIETRO. O princípio da supremacia do interesse público: sobrevivência diante dos ideais do neoliberalismo. in. Maria Sylvia Zanella DI PIETRO e Carlos Vinícius Alves RIBEIRO (coord.). Supremacia do interesse público e outros temas relevantes do direito administrativo. p. 94.

${ }^{451}$ Maria Sylvia Zanella DI PIETRO. Direito administrativo. p. 36.

${ }^{452}$ Cf. Daniel Wunder HACHEM. Princípio constitucional da supremacia do interesse público. p. 338.
} 


\section{CONCLUSÕES}

\section{Diagnóstico preliminar: a polissemia e a sinonímia como impasses linguísticos do debate}

Na companhia da chegada hora de concluir, vem certa lembrança sobre outro debate doutrinário conhecido e importante para os estudiosos do direito administrativo: o embate de ideias promovido entre Eros Roberto GRAU e Celso Antônio BANDEIRA de MELLO, no âmbito da teoria dos conceitos jurídicos indeterminados.

Por apertadíssimo resumo da polêmica ora rememorada, ${ }^{453}$ apenas registre-se que Celso Antônio BANDEIRA de MELLO não concordou com a colocação de Eros Roberto GRAU afirmando que conceitos jurídicos indeterminados, na verdade, não existem, eis que indeterminação linguística é qualidade a ser atribuída às palavras e não aos conceitos que elas expressam. E assim, na linha oposta, complementou que caso fosse, mesmo, imprecisa a palavra - não o conceito - bastaria a sua substituição por outra e isso resolveria a imprecisão daquilo que se quis comunicar. ${ }^{454}$

Neste momento, de modo tanto mais geral quanto menos técnico que o discutido por estes dois autores, é preciso assinalar, sem embargo, que se tais imprecisões de linguagem - sejam elas próprias dos conceitos ou dos termos que os rotulam - geram incertezas e ou dificuldades de entendimento sobre algum conteúdo comunicado é porque constituem, logicamente, problemas de comunicação.

Desta feita, fecha-se, aqui, o círculo de uma proposta de raciocínio que, com arrimo em alguns dos pensamentos propalados por Niklas LUHMANN, fora semeado nas considerações introdutórias desta pesquisa, no exato sentido de que, analiticamente, o direito deve ser concebido como um sistema de comunicação; um sistema a ser estudado, portanto, a partir dos seus problemas de comunicação.

\footnotetext{
${ }^{453} \mathrm{Um}$ relato mais substancioso sobre este diálogo, sem prejuízo, obviamente, da consulta dos textos originais dos interlocutores do debate ora mencionados, é encontrado no artigo: Dinorá Adelaide Musetti GROTTI. Conceitos jurídicos indeterminados e discricionariedade administrativa. in Cadernos de direito constitucional e ciência política, $\mathrm{n}^{\circ}$. 12. p. 87-88.

${ }^{454}$ Cf. Eros Roberto GRAU. O direito posto e o direito pressuposto. p. 197.
} 
Em relação aos problemas de comunicação que prejudicam, de maneira específica, o debate doutrinário acerca do princípio da supremacia do interesse público sobre o particular, algumas dificuldades devem ser apontadas, também de forma geral, quanto aos aspectos da polissemia e da sinonímia que caracterizam as palavras sobre as quais recaem as divergências teóricas apontadas e examinadas em cada uma das três dimensões de análise desenvolvidas na segunda parte da presente pesquisa.

Basicamente, então, identifica-se o problema da polissemia quando os autores divergem a respeito do significado de determinada locução, como a palavra "princípio", pois, como é cediço, esta carrega diversas possibilidades de significações. E o mesmo ocorre com a expressão "interesse público", vez que, no limite deste problema, a propósito, pode-se compreendê-lo tanto como interesse da sociedade quanto como interesse da administração pública. Destarte, também é possível que se o considere como interesse do Estado; neste caso, como os juristas definem a palavra Estado? Num sentido mais amplo, o conceito de Estado pode englobar a própria ideia de sociedade? E sem embargo, entretanto, não há quem, por via contrária, em muitos escritos, trate o Estado como sinônimo exclusivo de administração?

Neste ponto, verifica-se, também, o problema da sinonímia, que acontece, possivelmente, quando e porque os autores lançam mão de termos sinônimos, na busca de maior elegância linguística para a concatenação argumentativa dos seus discursos e, assim, acabam prejudicando a univocidade conceitual que pragmaticamente se espera de cada formulação terminológica, em termos científicos. Isso acontece, por exemplo, novamente, com a expressão "interesse público", já que frequentemente substituída por outras, tais como "interesses gerais", "interesses coletivos", "bens coletivos", "bem comum", "bens públicos" e etc.

É em razão de todo o entabulado que se afirma que a polissemia e a sinonímia certamente configuram impasses linguísticos que prejudicam o entendimento entre os doutrinadores no debate acerca do princípio da supremacia do interesse público sobre o particular no direito administrativo brasileiro. Trata-se, pois, de conclusão importante no contexto de esclarecimento a respeito da verificação da hipótese de pesquisa inicialmente formulada. 


\section{Verificação da hipótese de pesquisa}

Quando a polissemia e a sinonímia tornam-se problemas de comunicação, terminologias semanticamente incompatíveis podem expressar ideias similares. Algumas questões aprofundadas nas três dimensões de análise desenvolvidas demonstram que isso realmente ocorre, por diversas vezes, no debate ora investigado. Deste modo, não há dúvidas de que a hipótese de pesquisa formulada em sede introdutória resta, portanto, confirmada.

Todavia, se existem pontos de convergência doutrinária no debate acerca do princípio da supremacia do interesse público sobre o particular, é necessário que algo seja dito sobre eles. Afinal, não convém perder de vista as seguintes indagações, também formuladas em início de trabalho: quais seriam estes pontos de convergência doutrinária? Sobre o que, afinal, no direito administrativo brasileiro, concordam os críticos e os defensores do princípio da supremacia do interesse público sobre o particular?

O enfrentamento objetivo destas questões demanda o desenvolvimento de tópico próprio, destinado exclusivamente a este propósito.

\section{Síntese dos pontos convergentes identificados no debate}

Para iniciar esta síntese expositiva e objetiva dos consensos doutrinários que confirmam a hipótese formulada para o desenvolvimento da presente pesquisa, repisando, pois, as ilações alcançadas ao longo do exame então dedicado às três dimensões de análise do debate propostas, pode-se dizer que este estudo identificou, logo de plano, um primeiro bloco de convergências doutrinárias sobre o assunto, verificando, primeiramente, que no enfrentamento específico da matéria, a chamada indeterminação conceitual da noção jurídica de interesse público não é ignorada por nenhum doutrinador administrativista brasileiro; e, com efeito, verificando também que esta noção, do mesmo modo, aliás, resta compreendida de forma pluralizada por todos os integrantes do aludido debate doutrinário, eis que todos os autores que defendem o princípio da supremacia do interesse público sobre o particular não rejeitam a ideia de pluralidade de interesses públicos tal como problematizada pelos autores que, de outra banda, o criticam. 
Ainda em relação ao que pertine às dificuldades conceituais que envolvem a noção jurídica de interesse público, verificou-se uma interessante tendência doutrinária no sentido de bipartir conceitualmente esta expressão e isso acontece, basicamente, como já descrito, de duas formas: ou no intuito de contemplar a coexistência de um interesse público mais generalizado em contraste com outro, mais individualizado; ou na tentativa de respaldar uma espécie de pragmatismo, caracterizado por uma relação entre meios e fins, que considera a autoridade do Estado como meio para a consecução da finalidade pública, traduzida em ações afins com os interesses da sociedade. E neste ponto, a propósito, é de se repisar também que as distinções teóricas vislumbradas entre uma bipartição conceitual e outra, por certo, não podem ser desprezadas porque em que pesem serem motivadas por diferenças quanto aos ideais políticos e ideológicos de cada autor, não são - e nem podem ser - nutridas fora do principal paradoxo de equilíbrio do direito administrativo: a clássica dicotomia extremada pelos valores da autoridade e da liberdade. De qualquer modo, tem-se claro que a compreensão bipartida do conceito jurídico que reveste a noção de interesse público como objeto de estudo, a despeito das diferenças que marcam os diversos tipos de abordagem conceitual trazidos nesta pesquisa, também não deixam de evidenciar, portanto, um mínimo lógico de concordância doutrinária, pelo menos, quanto à metodologia de estudo do interesse público enquanto conceito jurídico.

Já em relação à polêmica que envolve a interpretação da doutrina administrativista brasileira e o seu possível erro de leitura acerca da formulação conceitual sustentada por Renato ALESSI e Celso Antônio BANDEIRA de MELLO, vislumbrou-se como primeiro sinal de convergência doutrinária o entendimento comum a todos os doutrinadores administrativistas deste país no sentido de que os interesses secundários - fora do mérito concernente ao equívoco terminológico então analisado - só podem ser atendidos quando coincidirem com o atendimento dos chamados "interesses públicos primários". Com isso, notou-se naturalmente a existência de um consenso doutrinário também na direção de que, conforme aponta Maria Sylvia Zanella DI PIETRO,“(...) embora o vocábulo público seja equívoco, pode-se dizer que, quando utilizado na expressão interesse público, ele se refere aos beneficiários da atividade administrativa e não aos entes que a exercem". Parece evidente, afinal, que, nos dias atuais, ninguém esteja a discordar de tal colocação.

Prosseguindo, outro importante ponto de convergência doutrinária registrada por esta pesquisa diz respeito ao problema de (in)compatibilidade entre o princípio da 
supremacia do interesse público sobre o particular e o princípio da proporcionalidade/razoabilidade, conforme então examinado. Neste quadrante, em termos objetivos, verificou-se que, do ponto de vista estritamente doutrinário, na verdade, este problema não existe, posto que os defensores da supremacia do interesse público sobre o particular - mesmo a despeito do potencial valor de incidência absoluta que a palavra "supremacia" possa carregar - não rejeitam a aplicação da proporcionalidade/razoabilidade como critério de ponderação ou sopesamento na aplicação do princípio ora debatido. Assim sendo, a relativização da supremacia do interesse público sobre o particular em face do princípio da proporcionalidade/razoabilidade também configura consenso entre os doutrinadores no direito administrativo brasileiro.

E por derradeiro, cabendo repisar o último dos consensos doutrinários identificados por esta pesquisa - aliás, possivelmente, o mais óbvio e também mais importante deles, vale dizer - deixou-se consignado que a concordância doutrinária geral "mesmo que por palavras discordantes" - de que com fulcro na sistemática constitucional, em que nem os interesses coletivos nem os individuais são absolutos, irrestritos ou ilimitados, os valores da dignidade da pessoa humana e dos direitos fundamentais do homem - vez que presentes nestas duas ordens de interesses ora mencionadas - terminam por traduzir os ideais que, sem dúvidas, consubstanciam a formulação conceitual do chamado interesse público digno de supremacia e centralidade no ordenamento jurídico; ideais estes, inquestionavelmente, vivos na mente de todo e qualquer administrativista brasileiro.

\section{Palavras finais}

O fim do caminho percorrido no decorrer de toda esta jornada alcança também algumas ilações que vão além dos consensos doutrinários imaginados e perseguidos em consonância com a verificação da hipótese de pesquisa formulada inicialmente.

Sem embargo, é de se bem considerar que tais ilações - não obstante desveladas fora dos objetivos propostos - também sejam potencialmente úteis para o debate doutrinário acerca do princípio da supremacia do interesse público sobre o particular no direito administrativo brasileiro, razão pela qual, portanto, seguem abaixo arroladas, 
porém, confessadamente, num sentido mais de complementação do estudo até aqui construído e acima finalizado.

Por este quadro, então, constatou-se que as divergências dos autores sobre as questões preponderantemente conceituais envolvendo a noção jurídica de interesse público estão, na realidade, intrinsecamente relacionadas com o contraste de perspectivas doutrinárias referido no quarto capítulo desta pesquisa, pois, como lá dito, não consistem em dizer se a mencionada noção comporta um conceito jurídico determinado ou indeterminado, tampouco se ela equivale a um fenômeno jurídico unitário ou pluralístico. Vistas por outro ângulo de mirada, afinal, e sendo cediço que ninguém da doutrina administrativista nacional rejeita os atributos de pluralidade e indeterminação conceitual da noção jurídica de interesse público, é de se perceber que estas divergências, na verdade, guardam íntima relação com a concepção de tais características como condições que justifiquem a eliminação ou a preservação do princípio da supremacia do interesse público sobre o particular dentro do direito administrativo brasileiro. Este entendimento, felizmente ou infelizmente, irá depender da compreensão que cada jurista possui sobre o sistema de direito como um todo.

Destarte, outro ângulo de visão parece ser viável, também, em relação às divergências teóricas concernentes ao caráter principiológico da supremacia do interesse público sobre o particular; campo em que se pôde verificar, tal como Fernando Dias MENEZES de ALMEIDA, “(...) uma excessiva ênfase na análise estrutural do funcionamento dos princípios em detrimento de uma análise finalística do conteúdo valorativo que encerram". A crítica que se faz, neste sentido, é que, de fato, muito pouco tem sido desenvolvido para além da já mencionada "solução universal da ponderação" que, segundo toda a doutrina, deve sempre ser lançada aos contextos fáticos donde são vislumbrados os conflitos de dois ou mais tipos distintos de interesses públicos sobretudo, nos casos específicos em que todos esses interesses desfrutam, igualmente, do mais alto grau de valoração constitucional -. Pelas palavras de Floriano Peixoto de Azevedo MARQUES NETO, “[a] questão central parece ser a da efetivação de um interesse público primário em detrimento de outro interesse público, também primário". ${ }^{45}$

\footnotetext{
455 "É o que se põe, por exemplo, quando o Poder Público se depara com a necessidade de decidir sobre a adoção de medidas que preservem um determinado ecossistema ou se promova o assentamento de famílias de agricultores para que, explorando aquela área, dela retirem seu sustento. Em ambos os casos seria sustentável
} 
A exceção à regra é verificada nas próprias lições do autor ora citado. Assim, vem a calhar o seu pensamento, lembrando que a obrigatoriedade de ponderação de todos os interesses públicos enredados no caso concreto, na realidade, configura apenas um dos subprincípios que orientam a função administrativa, devendo ser acompanhado de outros dois: a interdição do atendimento de interesses particularísticos ${ }^{456}$ e a imprescindibilidade de explicitação das razões de atendimento de um interesse público em detrimento dos demais. $^{457}$

No mais, a observação última e necessária para o desfecho definitivo da presente pesquisa atenta para a viabilidade - que deve ser observada por todos - dos alinhamentos conceituais, na maior medida possível, em cada assunto debatido doutrinariamente, em especial, no debate doutrinário acerca do princípio da supremacia do interesse público sobre o particular no direito administrativo brasileiro. Com isso, não se quer dizer que os doutrinadores devam compartilhar do mesmo conceito em relação a todos os objetos, até porque, tem-se na discussão conceitual, quase sempre, o aspecto teórico mais importante dos debates doutrinários. Contudo, é preciso que os doutrinadores procurem sempre explicitar quais são suas concepções acerca das expressões que designam o objeto, bem como estar plenamente cientes acerca das concepções adotadas pelos seus interlocutores.

a existência de interesse público primário”. in Floriano Peixoto de Azevedo MARQUES NETO. Regulação estatal e interesses públicos. p. 154.

456 "aqueles desprovidos de amplitude coletiva, transindividual" in Floriano Peixoto de Azevedo MARQUES NETO. Regulação estatal e interesses públicos. p. 165.

${ }^{457}$ Cf. Floriano Peixoto de Azevedo MARQUES NETO. Regulação estatal e interesses públicos. p. 165. 


\section{BIBLIOGRAFIA}

ABBOUD, Georges. O mito da supremacia do interesse público sobre o privado: a dimensão constitucional dos direitos fundamentais e os requisitos necessários para se autorizar restrição a direitos fundamentais. in Revista dos Tribunais. Vol. 100. $\mathrm{n}^{\circ}$. 907. p. 61-119.

ALESSI, Renato. Sistema istituzionale del diritto amministrativo italiano. Milano: Antonino Giuffrê, 1953.

ALEXY, Robert. Derecho y razón práctica. 2. ed. México: Fontamara, 1998.

Teoria dos direitos fundamentais. Tradução: Virgílio Afonso da Silva. São Paulo: Malheiros, 2006.

AMARAL, Diogo Freitas do. O direito administrativo sem estado - com a colaboração de Lino Torgal. Vol. II. Coimbra: Almedina, 2001.

ANDRADE, Vera Regina Pereira de. Dogmática e sistema penal: em busca da segurança jurídica prometida. Tese de Doutorado - Florianópolis: Faculdade de Direito, Universidade Federal de Santa Catarina. 1994.

ANTUNES, Luís Filipe Colaço. $O$ direito administrativo sem estado - crise ou fim de um paradigma? Coimbra: Coimbra, 2008.

ARAGÃO, Alexandre Santos de. A "Supremacia do Interesse Público" no advento do Estado de Direito e na hermenêutica do direito público contemporâneo. in SARMENTO, Daniel (org.). Interesses públicos versus interesses privados: desconstruindo o princípio da supremacia do interesse público. Rio de Janeiro: Lumen Juris, 2005.

.; MARQUES NETO, Floriano de Azevedo (Coord.) Direito administrativo e seus novos paradigmas. Belo Horizonte: Fórum, 2008.

ARAÚJO, Edmir Netto de. Curso de Direito Administrativo. 2. ed. São Paulo: Saraiva, 2010.

ATALIBA, Geraldo. Mudança da constituição. in Revista de Direito Público, n. ${ }^{\circ}$ 86. Ano 21. p.181-186. abril-junho de 1988. 
Sistema constitucional tributário brasileiro, São Paulo: Revista dos Tribunais, 1968.

ÁVILA, Humberto Bergmann. Repensando o "principio da supremacia do interesse público sobre o particular”. in SARMENTO, Daniel (org.). Interesses públicos versus interesses privados: desconstruindo o princípio da supremacia do interesse público. Rio de Janeiro: Lumen Juris, 2005.

Repensando o "princípio da supremacia do interesse público sobre o particular”. in Revista Trimestral de Direito Público. São Paulo: Malheiros. n. o 24, p. 159180, 1998.

BACELLAR FILHO, Romeu Felipe.; HACHEM, Daniel Wunder (coord.). Direito administrativo e interesse público: estudos em homenagem ao Professor Celso Antônio Bandeira de Mello. Belo Horizonte: Fórum, 2010.

A noção jurídica de interesse público no direito administrativo brasileiro. in BACELLAR FILHO, Romeu Felipe.; HACHEM, Daniel Wunder (coord.). Direito administrativo e interesse público: estudos em homenagem ao Professor Celso Antônio Bandeira de Mello. Belo Horizonte: Fórum, 2010.

BANDEIRA DE MELLO, Celso Antônio. A noção jurídica de "interesse público". in BANDEIRA de MELLO, Celso Antônio. Grandes temas de direito administrativo. São Paulo: Malheiros, 2010.

. Curso de direito administrativo. 28 ed. São Paulo: Malheiros, 2010.

. Curso de direito administrativo. 4 ed. São Paulo: Malheiros, 1993.

. Elementos de direito administrativo. São Paulo: Malheiros, 1991.

. Natureza e regime jurídico das autarquias. São Paulo: Revista dos Tribunais, 1968.

O Conteúdo do regime jurídico-administrativo e seu valor metodológico. in Revista de Direito Público, vol.2, 1967.

BANDEIRA DE MELLO, Oswaldo Aranha. Conceito de direito administrativo. in Revista da Universidade Católica de São Paulo, vol.XXVII, 1964. 
Princípios gerais de direito administraivo. v.1. Rio de Janeiro: Forense, 1969.

BAPTISTA, Izabelle de. O princípio da supremacia do interesse público sobre o privado: uma análise à luz dos direitos fundamentais e do Estado Democrático de Direito. in Fórum Administrativo - Direito Público. n. 130, Belo Horizonte: Fórum, p. 50-62, 2011.

BAPTISTA, Patrícia. Transformações do Direito Administrativo. Rio de Janeiro: Renovar, 2003.

BARROSO, Luís Roberto. A constitucionalização do direito e suas repercussões no âmbito administrativo. in ARAGÃO, Alexandre Santos de; MARQUES NETO, Floriano de Azevedo (Coord.) Direito administrativo e seus novos paradigmas. Belo Horizonte: Fórum, 2008.

Interpretação e aplicação da Constituição. São Paulo: Saraiva, 2004.

- Prefácio: $O$ Estado contemporâneo, os direitos fundamentais e a redefinição da supremacia do interesse público. in SARMENTO, Daniel (org.). Interesses públicos versus interesses privados: desconstruindo o princípio da supremacia do interesse público. Rio de Janeiro: Lumen Juris, 2005.

Neoconstitucionalismo e constitucionalização do direito (o triunfo tardio do direito constitucional no Brasil). in Revista Trimestral de Direito Público, ed. 44. p. 18-53. 2003.

BASTOS, Celso Ribeiro. Curso de direito administrativo. São Paulo: Saraiva. 1994.

BERTONCINI, Mateus Eduardo Siqueira Nunes. Princípios de direito administrativo brasileiro. São Paulo: Malheiros, 2002.

BIELSA, Rafael. Metodología jurídica. Santa Fé: Librería e Editorial Castellví S.A., 1961.

BIGOT, Gregóire. Introducion historieque au droit administratif depuis 1789. Paris: PUF, 2002.

BINENBOJM, Gustavo. Da supremacia do interesse público ao dever de proporcionalidade: um novo paradigma para o direito administrativo. in SARMENTO, Daniel (org.). Interesses públicos versus interesses privados: desconstruindo o princípio da supremacia do interesse público. Rio de Janeiro: Lumen Juris, 2005. 
. Uma Teoria do Direito Administrativo: direitos fundamentais, democracia e constitucionalização. Rio de Janeiro: Renovar, 2006.

BOBBIO, Norberto. Da estrutura à função: novos estudos de teoria do direito. Tradução: Daniela Beccaccia Versiani. Barueri, SP: Manole, 2007.

. Estado, governo e sociedade: para uma teoria geral da política. São Paulo: Paz e Terra, 2000.

BONAVIDES, Paulo. Curso de direito constitucional. 26.ed. São Paulo: Malheiros, 2011.

BORGES, Alice Gonzalez. Supremacia do interesse público: desconstrução ou reconstrução? in Interesse Público, n³7, Porto Alegre: Notadez, p. 29-48, maio/jun., 2006.

CAETANO, Marcello. Manual de direito administrativo. T. 1. Coimbra: Livraria Almedina, 2010.

CARRIÓ, Genaro R. Notas sobre derecho y lenguaje. Buenos Aires: Abeledo-Perrot, 1994.

CARVALHO, Iuri Mattos de. O princípio da supremacia do interesse público sobre o privado: parâmetros para uma reconstrução. in Revista Diálogo Jurídico. $\mathrm{n}^{\circ}$. 16. maiojunho-julho-agosto. 2007. Disponível em: http://www.direitopublico.com.br. Acesso em: 09 de setembro de 2009.

CARVALHO FILHO, José dos Santos. Interesse público: verdades e sofismas. in DI PIETRO, Maria Sylvia Zanella; RIBEIRO, Caio Vinícius Alves (coord.). Supremacia do interesse público e outros temas relevantes do direito administrativo. São Paulo: Atlas, 2010.

CASSESE, Sabino. Tendeze e problema del diritto amministrativo., in Rivista Trimestrale di Diritto Pubblico, Milão n. ${ }^{\circ}$ 4, 2004.

CAVALCANTI, Themístocles Brandão. Instituições de direito administrativo. Rio de Janeiro: Freitas Bastos. 1936.

CHEVAlliER, Jacques. Presentation, in CHEVALLIER, Jacques (org.). Public/Privé. Paris: PUF, 1995. 
CIRNE LIMA, Ruy. Princípios de direito administrativo brasileiro. Porto Alegre: Livraria Sulina, 1954.

COSTA, Alexandre Araújo. Introdução ao direito: uma perspectiva zetética das ciências jurídicas. Porto Alegre: Sergio Antonio Fabris Editor, 2001.

COSTA, Carlos Eduardo Batalha da Silva e. A filosofia jurídica como saber metaideológico: anotações a partir da função social da dogmática no enfoque de Tércio Sampaio Ferraz Jr in RODRIGUEZ, José Rodrigo; COSTA, Carlos Eduardo Batalha da Silva e; BARBOSA, Samuel Rodrigues (org.). Nas fornteiras do formalismo: a função social da dogmática jurídica hoje. São Paulo: Saraiva, 2010.

COSTALDELlO, Angela Cassia. A supremacia do interesse público e a cidade - a aproximação essencial para a efetividade dos direitos fundamentais. in BACELLAR FILHO, Romeu Felipe.; HACHEM, Daniel Wunder (coord.). Direito administrativo e interesse público: estudos em homenagem ao Professor Celso Antônio Bandeira de Mello. Belo Horizonte: Fórum, 2010.

CRETELLA JR, José. Dicionário de direito administrativo. 3. Ed. Rio de Janeiro: Forense, 1978.

. Direito administrativo brasileiro. v.1. Rio de Janeiro: Forense, 1983.

Filosofia do direito administrativo. Rio de Janeiro: Forense, 1999.

- Princípios informativos do direito administrativo. in Revista de Direito Administrativo. Rio de Janeiro: Fundação Getúlio Vargas. vol. 93. p. 1-10. 1968.

CRUZ, Alcides. Direito administrativo brasileiro: exposição summaria e abreviada. Paris: Aillaud, Alves \& Cia. 1914.

CUNHA Carlos Eduardo Bergamini. Discricionariedade administrativa e interesses públicos: superando a supremacia em busca da ponderação. in Fórum Administrativo. v. 11. n. 122. p. 9-21. 2011

CUNHA JÚNIOR, Dirley da. Curso de direito administrativo. 6. ed. Salvador: JusPODIVM, 2010.

DELGADO. José Augusto. Interesses difusos e coletivos: evolução conceitual - doutrina e jurisprudência do STF. in Revista Jurídica, n. 2 260. , jun. 1999. 
DIEZ, Manuel María. Derecho Administrativo. Buenos Aires: Bibliográfica Omeba, 1963.

DIMOULIS, Dimitri. Manual de introdução ao estudo do direito. São Paulo: Editora Revista dos Tribunais, 2007.

DI PIETRO, Maria Sylvia Zanella. Direito administrativo. 24. Ed. São Paulo: Atlas, 2011. . Discricionariedade administrativa na Constituição de 1988. São Paulo: Atlas. 1991.

Do direito privado na administração pública. São Paulo: Atlas, 1989.

Introdução: existe um novo direito administrativo? in DI PIETRO, Maria Sylvia Zanella; RIBEIRO, Caio Vinícius Alves (coord.). Supremacia do interesse público e outros temas de direito administrativo. São Paulo: Atlas, 2010.

Da constitucionalização do direito administrativo: reflexos sobre o princípio da legalidade e a discricionariedade administrativa. in DI PIETRO, Maria Sylvia Zanella; RIBEIRO, Caio Vinícius Alves (coord.). Supremacia do interesse público e outros temas de direito administrativo. São Paulo: Atlas, 2010.

O princípio da segurança jurídica diante do princípio da legalidade. in MARRARA, Thiago (org.). Princípios de direito administrativo: legalidade, segurança jurídica, impessoalidade, publicidade, motivação, eficiência, moralidade, razoabilidade, interesse público. São Paulo: Atlas, 2012.

O princípio da supremacia do interesse público: sobrevivência diante dos ideais do neoliberalismo. in DI PIETRO, Maria Sylvia Zanella; RIBEIRO, Caio Vinícius Alves (coord.). Supremacia do interesse público e outros temas de direito administrativo. São Paulo: Atlas, 2010.

O princípio da supremacia do interesse público: sobrevivência diante dos ideais do neoliberalismo. in Revista Trimestral de Direito Público, ed. 48. p. 63-76. 2004.

O direito administrativo brasileiro sob influência dos sistemas de base romanística e da Common Law. in Revista Eletrônica de Direito Administrativo Econômico. Salvador, Instituto Brasileiro de Direito Público, nº 8, novembro/dezembro de 2006/janeiro de 2007. Disponível em: <http://www.direitodoestado.com.br>. Acesso em: 27 de fevereiro de 2012. 
; RIBEIRO, Caio Vinícius Alves (coord.). Supremacia do interesse público e outros temas de direito administrativo. São Paulo: Atlas, 2010.

DUGUIT, León. Les transformations du droit public. Paris: Armand. Colin, 1913.

DWORKIN, Ronald. O Império do Direito. Tradução: Jefferson Luiz Camargo. Rio de Janeiro: Martins Fontes, 1999.

ESCOLA, Héctor Jorge. El Interés Público: como el fundamento del derecho administrativo. Buenos Aires: Depalma, 1989.

ESPÍNDOLA, Ruy Samuel. Conceito de principios constitucionais. São Paulo: Revista dos Tribunais, 1999.

FALDINI, Cristiana Corrêa Conde. A constitucionalização do direito administrativo. in DI PIETRO, Maria Sylvia Zanella; RIBEIRO, Caio Vinícius Alves (coord.). Supremacia do interesse público e outros temas de direito administrativo. São Paulo: Atlas, 2010.

FARIA, José Eduardo. Direito e economia na democratização brasileira. São Paulo: Malheiros, 1993.

FERRARI, Regina Maria Macedo Nery. A constitucionalização do direito administrativo e políticas públicas in. A\&C - Revista de Direito Administrativo \& Constitucional. p 271290. Belo Horizonte: Fórum. Ano 10. n . 40. abril/junho 2010.

- Reserva do possível, direitos fundamentais sociais e a supremacia do interesse público. in BACELLAR FILHO, Romeu Felipe.; HACHEM, Daniel Wunder (coord.). Direito administrativo e interesse público: estudos em homenagem ao Professor Celso Antônio Bandeira de Mello. Belo Horizonte: Fórum, 2010.

FERRAZ JR, Tercio Sampaio. Função social da dogmática jurídica. São Paulo: Max Limonad, 1998.

Introdução ao estudo do direito: técnica, decisão, dominação. São Paulo: Atlas, 2003.

FERREIRA, Aurélio Buarque de Holanda. Novo Aurélio Século XXI: o dicionário da língua portuguesa. 3.ed. Rio de Janeiro: Nova Fronteira, 1999. 
FERREIRA, Gustavo Assed. A legitimidade do Estado e a supremacia do interesse público sobre o interesse particular. in MARRARA, Thiago (org.). Princípios de direito administrativo: legalidade, segurança jurídica, impessoalidade, publicidade, motivação, eficiência, moralidade, razoabilidade, interesse público. São Paulo: Atlas, 2012.

FERRO, Murilo Ruiz. Princípio da dignidade da pessoa humana: o problema de um conceito. in Cadernos de iniciação científica, Faculdade de Direito de São Bernardo do Campo, n. 4. p. 95-102. 2007.

FIGUEIREDO, Lúcia Valle. Curso de direito administrativo. São Paulo: Malheiros. 1994.

FIGUEIREDO, Marcelo. Breve síntese da polêmica em torno do conceito de interesse público e sua supremacia: tese consistente ou devaneios doutrinários? in MARRARA, Thiago (org.). Princípios de direito administrativo: legalidade, segurança jurídica, impessoalidade, publicidade, motivação, eficiência, moralidade, razoabilidade, interesse público. São Paulo: Atlas, 2012.

Probidade administrativa (comentários à lei 8.429 e legislação complementar) 10 ed. São Paulo: Malheiros, 2009.

FINGER, Ana Cláudia. O princípio da boa-fé e a supremacia do interesse público fundamentos da estabilidade do ato administrativo. in BACELLAR FILHO, Romeu Felipe.; HACHEM, Daniel Wunder (coord.). Direito administrativo e interesse público: estudos em homenagem ao Professor Celso Antônio Bandeira de Mello. Belo Horizonte: Fórum, 2010.

FIUZA, César. Direito civil: curso completo. 10.ed. Belo Horizonte: Del Rey, 2007.

FONSECA, Tito Prates da. Lições de direito administrativo. Rio de Janeiro: Freitas Bastos. 1943.

FORSTHOFF, Ernst. Traité de droit administratif allemand. Trad. Michel Fromont. Bruxelas: Bruyland, 1968.

FRANÇA, Maria Adelaide de Campos. Supremacia do interesse públicos versus supremacia dos direitos individuais. in DI PIETRO, Maria Sylvia Zanella; RIBEIRO, Caio Vinícius Alves (coord.). Supremacia do interesse público e outros temas de direito administrativo. São Paulo: Atlas, 2010. 
FROTA, Hidemberg Alves da. O princípio da supremacia do interesse público sobre o privado no direito positivo comparado: expressão do interesse geral da sociedade e da soberania popular. in Revista da Faculdade de Direito da Universidade de Lisboa. Lisboa. v. 45. n.1/2. P. 229-250, 2004.

FURTADO de MENDONÇA, Francisco Maria de Souza. Excerpto de direito administrativo pátrio. São Paulo: Typographia Allemã de Henrique Schroeder, 1865.

GABARDO, Emerson. Interesse público e subsidariedade: o Estado e a sociedade civil para além do bem e do mal. Belo Horizonte: Fórum, 2009.

.; HACHEM, Daniel Wunder. O suposto caráter autoritário da supremacia do inteteresse público e das origens do direito administrativo: uma crítica da crítica. in DI PIETRO, Maria Sylvia Zanella; RIBEIRO, Caio Vinícius Alves (coord.). Supremacia do interesse público e outros temas de direito administrativo. São Paulo: Atlas, 2010.

GASPARINI, Diogenes. Direito administrativo.10 ed. São Paulo: Saraiva. 2005.

Direito administrativo. 2. ed. São Paulo: Saraiva. 1992.

GIACOMUZZI, José Guilherme. Estado e contrato: supremacia do interesse público "versus" igualdade - um estudo comparado sobre a exorbitância no contrato administrativo. São Paulo: Malheiros, 2011.

GIANNINI, Massimo Severo. Diritto Amministrativo. Volume primo. Terza edizione. Milano: Giuffrè Editore, 1993.

GRAU, Eros Roberto. A ordem econômica na constituição de 1988. 7. ed. São Paulo: Malheiros, 2002.

Ensaio sobre a interpretação/aplicação do direito. São Paulo: Malheiros, 2003. O direito posto e o direito pressuposto. São Paulo: Malheiros, 2005.

GRINOVER, Ada Pellegrini. A problemática dos interesses difusos. in GRINOVER, Ada Pellegrini (coord.). A tutela dos interesses difusos. São Paulo: Max Limonad. 1984.

GROTTI, Dinorá Adelaide Musetti. Conceitos jurídicos indeterminados e discricionariedade administrativa. in Cadernos de direito constitucional e ciência política. São Paulo: Revista dos Tribunais, 1995. n. 12. p. 84-115. 
GUEDES, Ricardo Catunda N. Supremacia do interesse público sobre interesse privado em face dos direitos fundamentais. in Revista Mestrado em Direito. Ano 7. n . 1. p. 273 287.

GUIMARÃES, Bernardo Strobel. O exercício da função administrativa e o direito privado. Tese de Doutorado - São Paulo: Faculdade de Direito, Universidade de São Paulo. 2010.

HACHEM, Daniel Wunder. Princípio constitucional da supremacia do interesse público. Belo Horizonte: Fórum, 2011.

HAURIOU, Maurice. Précis de droit administratif et e droit public géneral. 11. Ed. Bordeaux: Imprimerie Cadout, 1927.

HORA, Marco Aurélio Senko da A relativização da supremacia do interesse público em face do fundamento constitucional da dignidade da pessoa humana. in Revista do Tribunal Regional do Trabalho da $9^{a}$ Região. v. 36. n. 67. p. 631-657. 2011

HOUAISS, Antônio; VILLAR, Mauro de Salles. Dicionário Houaiss da língua portuguesa. Rio de Janeiro: Objetiva, 2001.

JUSTEN FILHO, Marçal. Conceito de interesse público e "personalização do direito administrativo. in Revista Trimestral de Direito Público, n²6, São Paulo: Malheiros, p. 115-136, 1999.

. Curso de direito administrativo. 5. ed. São Paulo: Saraiva, 2010.

O direito administrativo de espetáculo. in ARAGÃO, Alexandre Santos de; MARQUES NETO, Floriano de Azevedo (Coord.) Direito administrativo e seus novos paradigmas. Belo Horizonte: Fórum, 2008.

KNIJNIK, Danilo; O recurso especial e a revisão da questão de fato pelo Superior Tribunal de Justiça. Rio de Janeiro: Forense, 2005.

LEITE, Carlos Henrique Costa. A interpretação da idéia de supremacia do interesse público sobre o privado no paradigma do Estado democrático de direito. in Revista Forense. v. 107. n. 414. p. 69-100. 2011.

LIMA, Gabriel de Araújo. Teoria da supremacia do interesse público: crises, contradições e incompatibilidade de seus fundamentos com a Constituição Federal. in Revista de 
Direito Administrativo e Constitucional. Belo Horizonte: Fórum. n. ${ }^{\circ}$ 36, p. 123-153, abr/jun. 2009.

LITRENTO, Oliveiros; A doutrina na ordem jurídica: pressupostos fundamentais $e$ subisídios para sua positividade. Rio de Janeiro: Forense Universitária, 1994.

LUHMANN, Niklas. La ciencia de la sociedad. Mexico: Anthropos, 1996.

- Sistema juridico y dogmatica juridica. Madrid: Centro de Estudios Constitucionales, 1983.

MAIA, Cristiano Soares. A (im)pertinência do princípio da supremacia do interesse público sobre o particular no contexto do Estado Democrático de Direito. in Fórum Administrativo - Direito Público. n. 103, Belo Horizonte: Fórum, p. 17-28, 2009.

MANCUSO, Rodolfo de Camargo. Interesses difusos. Conceito e legitimação para agir. 5. ed. São Paulo: Revista dos Tribunais, 2000.

MARANHÃO, Juliano Souza de Albuquerque; $O$ discurso da dogmática jurídica., in Nas fronteiras do formalismo: a função social da dogmática jurídica hoje. in RODRIGUEZ, José Rodrigo; COSTA, Carlos Eduardo Batalha da Silva e; BARBOSA, Samuel Rodrigues (org.). Nas fornteiras do formalismo: a função social da dogmática jurídica hoje. São Paulo: Saraiva, 2010.

MARCONDES, Roberto Rangel. . A importância da participação popular na definição do interesse público a ser tutelado pelo Ministério Público do Trabalho. Tese de Doutorado São Paulo: Faculdade de Direito, Universidade de São Paulo. 2010.

MARQUES NETO, Floriano Peixoto de Azevedo. A responsabilidade objetiva das concessionárias de serviço público: a jurisprudência do STF e o papel da doutrina. in Revista de Direito Administrativo Contemporâneo. São Paulo: Revista dos Tribunais. Ano 1. vol.0. p. 15-30, mai/jun. 2013.

Interesses públicos e privados na atividade estatal de regulação. in MARRARA, Thiago (org.). Princípios de direito administrativo: legalidade, segurança jurídica, impessoalidade, publicidade, motivação, eficiência, moralidade, razoabilidade, interesse público. São Paulo: Atlas, 2012.

Regulação Estatal e Interesses Públicos. São Paulo: Malheiros, 2002. 
O conflito entre princípios constitucionais: breves pautas para sua solução.. in Cadernos de direito constitucional e ciência política. São Paulo: Revista dos Tribunais, 1995. $\mathrm{n}^{\circ}$. 10. p. 40-45.

MARRARA, Thiago (org.). Princípios de direito administrativo: legalidade, segurança jurídica, impessoalidade, publicidade, motivação, eficiência, moralidade, razoabilidade, interesse público. São Paulo: Atlas, 2012.

MAXIMILIANO, Carlos. Hermenêutica e aplicação do direito. 11. ed. Rio de Janeiro: Forense, 2003.

MEDAUAR, Odete. Direito administrativo em evolução. 2. ed. São Paulo: Revista dos Tribunais, 2003.

MEIRELLES, Hely Lopes. Direito administrativo brasileiro. São Paulo: Revista dos Tribunais, 1964.

MEIRELLES TEIXEIRA, José Horácio. Estudos de direito administrativo. v.1. São Paulo: Departamento Jurídico da Prefeitura Municipal de São Paulo. 1949.

MENDES de ALMEIDA, Fernando Henrique. Noções de direito administrativo. São Paulo: Saraiva. 1956.

MENDES JR., Onofre. Direito administrativo. Belo Horizonte: Bernardo Álvares S.A. 1961.

MENDONÇA, João Josué Walmor de. Fundamentos da supremacia do interesse público. Porto Alegre: Núria Fabris. 2012.

MENEZES de ALMEIDA, Fernando Dias. Contrato administrativo. São Paulo: Quartier Latin, 2012.

Princípio da impessoalidade. in MARRARA, Thiago (org.). Princípios de direito administrativo: legalidade, segurança jurídica, impessoalidade, publicidade, motivação, eficiência, moralidade, razoabilidade, interesse público. São Paulo: Atlas, 2012.

MORAES, Alexandre de. Constitucionalização do direito administrativo e princípio da eficiência. in. Carlos Maurício FIGUEIREDO e Marcos NÓBREGA (org.). Direito 
administrativo, financeiro e gestão pública: prática, inovações e problemas. São Paulo: Revista dos Tribunais, 2002.

MOREIRA NETO, Diogo de Figueiredo. Mutações do direito administrativo. 2. ed. Rio de Janeiro: Renovar. 2001.

Quatro paradigmas do direito administrativo pós-moderno. Belo Horizonte: Fórum. 2008.

MOTTA, Paulo Roberto Ferreira. A supremacia do interesse público (e a sua indisponibilidade) e os direitos fundamentais: o caso Glória Trevi . in . A\&C - Revista de Direito Administrativo \& Constitucional. p. 251-269. Belo Horizonte: Fórum. Ano 10. $\mathrm{n}^{\circ}$. 40. abril/junho 2010.

Direito administrativo - direito da supremacia do interesse público. in BACELLAR FILHO, Romeu Felipe.; HACHEM, Daniel Wunder (coord.). Direito administrativo e interesse público: estudos em homenagem ao Professor Celso Antônio Bandeira de Mello. Belo Horizonte: Fórum, 2010.

MUKAI, Toshio. Direito administrativo sistematizado. São Paulo: Saraiva. 1999.

MUÑOZ, Guillermo Andrés. El interés público es como el amor. in BACELLAR FILHO, Romeu Felipe.; HACHEM, Daniel Wunder (coord.). Direito administrativo e interesse público: estudos em homenagem ao Professor Celso Antônio Bandeira de Mello. Belo Horizonte: Fórum, 2010.

NADER, Paulo. Introdução ao estudo do direito. 35. ed. Rio de Janeiro: Forense, 2013.

NEQUETE, Eunice Ferreira. Fundamentos históricos do princípio da supremacia do interesse público. Dissertação de Mestrado - Porto Alegre: Faculdade de Direito, Universidade Federal do Rio Grande do Sul. 2005.

NEVES, Zuenir de Oliveira. Por uma releitura da supremacia do interesse público no contexto do Estado democrático de direito. in Fórum Administrativo. v. 11. n. 121. p. 4048. mar.2011.

NOHARA, Irene Patrícia. Reflexões críticas acerca da tentativa de desconstrução do sentido da supremacia do interesse público no direito administrativo. in DI PIETRO, 
Maria Sylvia Zanella; RIBEIRO, Caio Vinícius Alves (coord.). Supremacia do interesse público e outros temas relevantes do direito administrativo. São Paulo: Atlas, 2010.

OLIVEIRA, José Roberto Pimenta. Os princípios da razoabilidade e da proporcionalidade no direito administrativo brasileiro. São Paulo: Malheiros. 2006.

OLIVEIRA SANTOS, Eurico de. Direito administrativo e sciencia da administração. Rio de Janeiro: Jacintho Ribeiro dos Santos. 1919.

OSÓRIO, Fábio Medina. Existe uma supremacia do interesse público sobre o privado no direito administrativo brasileiro? in Revista dos Tribunais. São Paulo: Vol. 88. n. 770. p. 53-92, dezembro de 1999.

PALMA, Juliana Bonacorsi de. Atuação administrativa consensual: estudo dos acordos substitutivos no processo administrativo sancionador. Dissertação de Mestrado - São Paulo: Faculdade de Direito, Universidade de São Paulo. 2010.

PEDRO, Fábio Anderson de Freitas. O sigilo empregado nos processos de investigação de acidentes aéreos no Brasil e a primazia do interesse público. in Revista Forense. vol. 414. p. 536554. jul/dez. 2011

PEDRON, Flavio Quinaud. O dogma da supremacia do interesse público e seu abrandamento pela jurisprudência do Supremo Tribunal Federal através da técnica da ponderação de princípios in A\&C-Revista de Direito Administrativo \& Constitucional, $\mathrm{n}^{\circ}$. 40. p. 271-290.

PIMENTA BUENO, José Antônio. Direito publico brazileiro e analyse da constituição do Império. Rio de Janeiro: Typographia Imp. E Const. de J. Villeneuve e C. 1857.

PIOVESAN, Flávia. Direitos humanos e o direito constitucional internacional. $9^{\circ}$ ed. São Paulo: Saraiva, 2008.

PIZZORUSSO, Alessandro. Interesse pubblico e interessi pubblici. in Rivista Trimestrale di Diritto e Procedura Civile. Milano: Antonino Giuffrê, n. 4. P. 57-87. Dicembre 1973

PONDÉ, Lafayette de Azevedo. A doutrina e a jurisprudência na elaboração do direito administrativo. in Revista de Direito Administrativo. Rio de Janeiro: Renovar. v.196. p. 8593, abr/jun. 1994. 
PORCHAT, Reynaldo. Curso elementar de direito romano. v.I. São Paulo: Duprat \& Cia., 1907.

RADBRUCH, Gustav. Filosofia do direito. $2^{\circ}$ ed. Trad. Marlene Holzhausen. São Paulo: Martins Fontes, 2010.

REALE, Miguel. Filosofia do direito. $4^{\circ}$ ed. São Paulo: Saraiva, 1965. Lições preliminares de direito. $3^{\circ}$ ed. São Paulo: Saraiva, 1976.

REICH, Norbert. Intervenção do Estado na economia (reflexões sobre a pós-modernidade na teoria jurídica). in Revista de Direito Público, n. ${ }^{\circ}$ 94. Ano 23. abril-junho de 1990.

REIS, Aarão. Direito administrativo brazileiro. Rio de Janeiro: Officinas Graphicas Villas Boas \& C. 1923.

RIBAS, Antonio Joaquim. Ensaio sobre o direito administrativo. Rio de Janeiro: F. L. Pinto \& C. 1866.

RIBEIRO, Carlos Vinícius Alves. Interesse público: um conceito jurídico determinável. in. DI PIETRO, Maria Sylvia Zanella; RIBEIRO, Carlos Vinícius Alves. (coord.). Supremacia do interesse público e outros temas relevantes do direito administrativo. p. 103-119.

RIVERO, Jean. Direito administrativo. Trad. Rogério Ehrhardt Soares. Coimbra: Almedina, 1981.

ROBERTO, Luiz Fernando. Supremacia do interesse público sobre o interesse privado: um panorama crítico da desconstrução do princípio. in Revista da Procuradoria Geral do Estado de São Paulo. São Paulo: v.71, p. 195-215, janeiro/junho de 2010.

RODRIGUEZ, José Rodrigo. A persistência do formalismo: uma crítica para além da separação de poderes, in RODRIGUEZ, José Rodrigo; COSTA, Carlos Eduardo Batalha da Silva e; BARBOSA, Samuel Rodrigues (org.). Nas fornteiras do formalismo: a função social da dogmática jurídica hoje. São Paulo: Saraiva, 2010.

ROSS, Alf Niels Christian. Direito e justiça. 2. Ed. Tradução: Edson Bini. Bauru: Edipro, 2007.

SAINZ MORENO, Fernando. Conceptos jurídicos, interpetación y discrecionalidad administrativa. Madrid: Civitas S/A, 1976. 
SAMUEL, Geoffrey. Epistemoloy and method in law. Aldershot/Eng., Ashgate, 2003.

SANTOS NETO, João Antunes do. O impacto dos direitos humanos fundamentais no direito administrativo. Belo Horizonte: Fórum, 2008.

SARMENTO, Daniel (org.). Interesses públicos versus interesses privados: desconstruindo o princípio da supremacia do interesse público. Rio de Janeiro: Lumen Juris, 2005.

Interesses públicos vs. interesses privados na perspectiva da teoria e da filosofia constitucional. in SARMENTO, Daniel (org.). Interesses públicos versus interesses privados: desconstruindo o princípio da supremacia do interesse público. Rio de Janeiro: Lumen Juris, 2005.

Supremacia do interesse público? As colisões entre direitos fundamentais e interesses da coletividade. in ARAGÃO, Alexandre Santos de; MARQUES NETO, Floriano de Azevedo (Coord.) Direito administrativo e seus novos paradigmas. Belo Horizonte: Fórum, 2008.

SCHIER, Adriana da Costa Ricardo. O princípio da supremacia do interesse público sobre o privado e o direito de greve de servidores públicos. in BACELLAR FILHO, Romeu Felipe.; HACHEM, Daniel Wunder (coord.). Direito administrativo e interesse público: estudos em homenagem ao Professor Celso Antônio Bandeira de Mello. Belo Horizonte: Fórum, 2010.

SCHIER, Paulo Ricardo. Ensaio sobre a supremacia do interesse público sobre o privado e o regime jurídico dos direitos fundamentais. in Revista da Academia Brasileira de Direito Constitucional, v. 5. p. 527-551. 2004.

Ensaio sobre a supremacia do interesse público sobre o privado e o regime jurídico dos direitos fundamentais. in SARMENTO, Daniel. (org.). Interesses públicos versus interesses privados: desconstruindo o princípio da supremacia do interesse público. Rio de Janeiro: Lumen Juris, 2005.

SENHORAS, Elói Martins; Souza Cruz, Ariane Raquel Almeida de. Debates sobre o princípio da supremacia do interesse público sobre o privado. in in Repertório de jurisprudência IOB , n. 24 - vol.I. p. 798. 
SILVA, Virgílio Afonso da. A Constitucionalização do Direito - Os direitos fundamentais nas relações entre particulares. São Paulo: Malheiros, 2007.

. Direitos fundamentais - conteúdo essencial, restrições e eficácia. São Paulo: Malheiros, 2009.

Interpretação constitucional e sincretismo metodológico.in SILVA, Virgílio Afonso da. (org.). Interpretação constitucional. São Paulo: Malheiros, 2010.

O proporcional e o razoável. in Revista dos Tribunais. São Paulo: Ano 91. Vol. 798. p. 23-50, abril de 202.

Princípios e regras: mitos e equívocos acerca de uma distinção. in Revista Latino-Americana de Estudos Constitucionais 1.p. 607-630. 2003

SILVEIRA, Raquel Dias da. Princípio da supremacia do interesse público como fundamento das relações de trabalho entre servidores públicos e Estado. in BACELLAR FILHO, Romeu Felipe.; HACHEM, Daniel Wunder (coord.). Direito administrativo e interesse público: estudos em homenagem ao Professor Celso Antônio Bandeira de Mello. Belo Horizonte: Fórum, 2010.

SOARES, Murilo Rodrigues da Cunha. Dogmática jurídica entre reflexão e redundância: uma análise luhmmaniana da produção acadêmica na área do direito tributário. Trabalho de Conclusão de Curso de Bacharelado - Brasília: Faculdade de Direito, Universidade de Brasília. 2006.

SOARES, Rogério Ehrhardt. Interesse público, legalidade e mérito. Coimbra: [s.n.], 1955.

SULZBACH, Lívia Deprá Camargo. A responsabilidade subsidiária da administração pública na terceirização de serviços - princípio da supremacia do interesse público $x$ dignidade da pessoa humana? Repercussões do julgamento da ADC n. 16 pelo STF na súmula n. 331 do TST. in LTr: Revista Legislação do Trabalho. v. 76. n. 6. p. 736.

SUNDFELD, Carlos Ari. Fundamentos de direito público. 5. Ed. São Paulo: Malheiros, 2011.

Interesse público em sentido mínimo e sentido forte: o problema da vigilância epidemológica frente aos direitos constitucionais. in Revista Interesse Público. n.28, Porto Alegre: Notadez, 2010. p. 29-42, nov./dez. 2004. 
Princípio é preguiça? in Carlos Ari SUNDFELD. Direito administrativo para céticos. São Paulo: Malheiros. 2012.

TÁCITO, Caio. O poder de polícia e seus limites. in Revista de Direito Administrativo. in Revista de Direito Administrativo. n.27, Rio de Janeiro: Fundação Getúlio Vargas, 2010. p. 1-11, jan./mar. 1952.

TAVARES, André Ramos; BOLZAN, Fabrício. Poder de polícia:da supremacia do interesse público à primazia dos direitos fundamentais. in DALLARI, Adilson Abreu; NASCIMENTO, Carlos Valder do; MARTINS, Ives Gandra da Silva. (coord.). Tratado de direito administrativo, 2. São Paulo: Saraiva. 2013.

URUGUAY, Visconde do, Paulino José Soares de Souza. Ensaio sobre o direito administrativo. Rio de Janeiro: Nacional. 1862.

VALDIVIA, Diego Zegarra. El servicio público: fundamentos. Lima: Palestra Editores. 2005 .

VEIGA CABRAL, Prudencio Giraldes Tavares da. Direito administrativo brasileiro. Rio de Janeiro: Typographia Universal de Laemert. 1859.

VIVEIROS de CASTRO, Augusto Olympio. Tratado de sciencia da administração e direito administrativo. Rio de Janeiro: Imprensa Nacional. 1906.

WARAT, Luis Alberto; Mitos e teorias na interpretação da lei. Porto Alegre: Síntese, 1982. 